\begin{abstract}
Universidade de São Paulo
Faculdade de Filosofia, Letras e Ciências Humanas

Departamento de Geografia

Programa de Pós-Graduação em Geografia Física

\section{A QUESTÃO DOS CRÉDITOS DE CARBONO E SUA VIABILIDADE ECONÔMICA AMBIENTAL}

Eduardo Del Nery Calestini

Profa. Dra. Sidneide Manfredini

São Paulo

2012 


\section{A QUESTÃO DOS CRÉDITOS DE CARBONO E SUA VIABILIDADE ECONÔMICA E AMBIENTAL}

\section{(VERSÃO CORRIGIDA)}

Dissertação apresentada ao Programa de PósGraduação em Geografia Física da Faculdade de Filosofia, Letras e Ciências Humanas da Universidade de São Paulo, para obtenção do título de mestre em Geografia Física.

Orientadora: Profa. Dra. Sidneide Manfredini

“de acordo" Dra. Sidneide Manfredini

São Paulo 
Autorizo a reprodução e divulgação total ou parcial deste trabalho para fins de estudo e pesquisa, desde que citada a fonte.

Calestini, Eduardo Del Nery. A Questão dos Créditos de Carbono e sua Viabilidade Econômica Ambiental / Eduardo Del Nery Calestini; orientador: Sidneide Manfredini - São Paulo, Brasil, 2012.

203p.

Dissertação (Mestrado - Programa de Pós-Graduação em Geografia Física. Linha de pesquisa: Meio Ambiente, Sustentabilidade, Créditos de Carbono, MDL, Serviços Ambientais) - Faculdade de Filosofia, Letras e Ciências Humanas, Programa de Pós-Graduação em Geografia Física da Universidade de São Paulo.

1. Mercado de Carbono. 2. Sustentabilidade. 3. MDL. I. Universidade de São Paulo. Programa de Pós-Graduação em Geografia Física. II. Título. 
Nome: Calestini, Eduardo Del Nery

Título: A Questão dos Créditos de Carbono e sua Viabilidade Econômica Ambiental

Dissertação apresentada ao Programa de Pós-Graduação em Geografia Física da Faculdade de Filosofia, Letras e Ciências Humanas da Universidade de São Paulo, para obtenção do título de mestre em Geografia Física.

Aprovado em:

Banca examinadora

Profa. Dra. Sidneide Manfredini

Instituição: Universidade de São Paulo. Assinatura

Prof. Dra. Cristina Adams

Instituição: Universidade de São Paulo. Assinatura

Prof. Dr. Mário Di Biase

Instituição: Universidade de São Paulo. Assinatura 
A Raquel, pelo apoio incondicional. 


\section{AGRADECIMENTOS}

Agradeço, especialmente, à minha orientadora Profa. Dra. Sidneide Manfredini pela orientação desta pesquisa e pelas aulas dadas a cada reunião de orientação que foram as melhores que tive durante minha vida acadêmica.

Sou muito grato ao Prof. Dr. José Bueno Conti pelas aulas ministradas durante o programa de mestrado e principalmente pelos atendimentos realizados durante a construção da presente pesquisa.

À minha esposa Raquel que me incentivou e apoiou nos momentos mais críticos, com amor e companheirismo, dignos de uma grande mulher, e que foi verdadeiramente compreensível às minhas frustrações, abdicando de muitos de seus compromissos em prol do desenvolvimento dessa pesquisa.

A minha família, em especial aos meus pais, pelas oportunidades oferecidas, pelo apoio e carinho.

A Deus pela proteção. 
Calestini, Eduardo Del Nery. A Questão dos Créditos de Carbono e sua Viabilidade Econômica Ambiental / Eduardo Del Nery Calestini; orientador: Sidneide Manfredini - São Paulo, Brasil, 2012. $203 \mathrm{p}$.

\section{RESUMO}

As mudanças climáticas provocadas pelo Homem induziram a formação de um mercado que segue atividades que afirmam contemplar aspectos de desenvolvimento sustentável. O mecanismo de desenvolvimento limpo (MDL) é um dos instrumentos de flexibilização estabelecido pelo protocolo de Quioto com o objetivo de facilitar o cumprimento das metas de redução de emissão de gases de efeito estufa (GEE), definidas para os países que o ratificaram, tratando do desenvolvimento e da implantação de projetos visando à redução de emissões de gases de efeito estufa nos países em desenvolvimento, financiado pelos países desenvolvidos, em troca de créditos para serem abatidos dos seus compromissos de redução de emissões. Os projetos que se habilitarem à condição de projeto de MDL deverão cumprir uma série de procedimentos até receber a chancela da ONU e, consequentemente, certificar as reduções alcançadas. $\mathrm{O}$ presente trabalho tem o objetivo de analisar quais são os requisitos para a implantação de um MDL e discutir a real promoção da sustentabilidade do dispositivo, bem como a viabilidade econômica e ambiental, conforme preconiza o artigo 12 do Protocolo de Quioto. Para o cumprimento da presente tarefa foi necessária a análise dos antecedentes do Mecanismo de Desenvolvimento Limpo, a saber: As mudanças climáticas globais, a Convenção-Quadro das Nações Unidas sobre Mudança do Clima e o Protocolo de Quioto. Em seguida foram analisados dois projetos utilizando MDL sob dois aspectos diferenciados. O primeiro advindo de reduções de emissões em um aterro sanitário, na cidade de São Paulo, o segundo relacionado à silvicultura, no interior do mesmo Estado.

Palavras-chave: Mercado de carbono, MDL, desenvolvimento sustentável. 
Calestini, Eduardo Del Nery. A Questão dos Créditos de Carbono e sua Viabilidade Econômica Ambiental / Eduardo Del Nery Calestini; orientador: Sidneide Manfredini - São Paulo, Brasil, 2012. 203p.

\begin{abstract}
Climate change caused by man induced the formation of a market that follows activities that claim to include elements of sustainable development. The Clean Development Mechanism $(\mathrm{CDM})$ is one of the Kyoto Protocol flexibilization instruments in order to facilitate the achievement of greenhouse gases (GHGs) emission reducing goals defined for the countries which have ratified it, treating of development and implementation of projects in order to reduce GHGs emission in developing countries, financed by developed countries, in exchange for credits to be deducted from their commitments to reduce emissions.
\end{abstract}

Projects that qualify for CDM project status must meet a series of procedures to receive the United Nation (UN) approval and consequently, certify the achieved reductions.

This study aims to examine which are the requirements for implementation of a CDM and discuss the actual promotion of the device sustainability as well as economic and environmental viability, as defined in article 12 of the Kyoto Protocol. In fulfillment of this task it was necessary to analyze the background of the CDM, as follows: Global climate changes, the UN Framework Convention on Climate Change and the Kyoto Protocol. Next, two projects were analyzed using CDM under two different aspects. The first about emission reductions in a landfill, in the city of Sao Paulo, the second related to growing eucalyptus, in the countryside of the same state.

Keywords: Carbon Market, CDM, Sustainable Development. 


\section{LISTA DE ILUSTRAÇÕES}

Figura 1: Esquema simplificado do ciclo do carbono

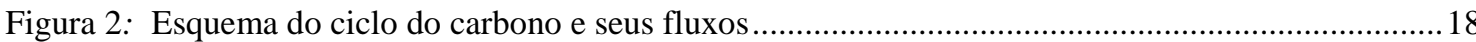

Figura 3: Balanço energético global a partir da energia luminosa proveniente do sol.

Figura 4: Alterações antropogênicas no ciclo do carbono resultantes do aumento no uso de combustíveis fósseis e mudança de padrões de ocupação do solo. As setas indicam a magnitude média de perturbação26

Figura 5: Número de atividades de projeto no âmbito do MDL no mundo

Figura 6: Participação no total de atividades de projeto no âmbito do MDL no mundo

Figura 7: Participação no Potencial de Redução de emissões para o primeiro período de obtenção de créditos

Figura 8: Distribuição das atividades de projeto no Brasil por escopo setorial

Figura 9 - Geração de Resíduos Sólidos Urbanos no Brasil

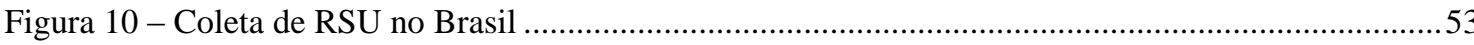

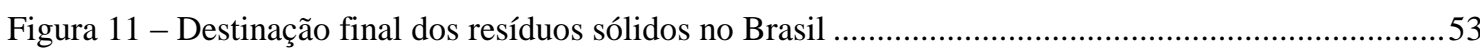

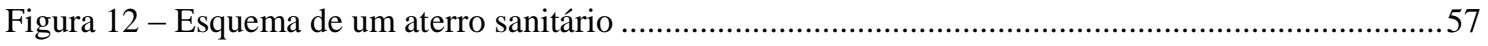

Figura 13 - Modelo esquemático de um aterro controlado ...............................................................58

Figura 14 - Modelo esquemático de um aterro sanitário.............................................................58

Figura 15: Divisão político administrativa dos municípios do Estado de São Paulo-SP..........................60

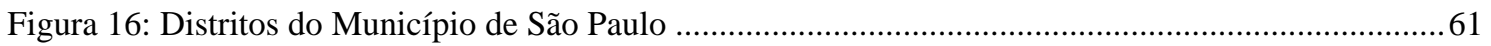

Figura 17: Região de Perus, Município de São Paulo-SP......................................................................62

Figura 18: Aterro Sanitário Bandeirantes - SP (A área em vermelho corresponde aos limites do aterro sanitário)

Figura 19: Aterro Bandeirantes: comparação entre $\mathrm{tCO}_{2} \mathrm{e}$ estimadas no documento de concepção dos projetos (DCPs) e efetivamente geradas nos Relatórios de Monitoramento.

Figura 20: Mapa do Estado de Minas Gerais

Figura 21: Região do Projeto Plantar - Cidades de Curvelo, Felixlândia e Morada Nova de Minas. .......70

Figura 22: Região do Projeto Plantar (satélite) - Cidades de Curvelo, Felixlândia e Morada Nova de Minas

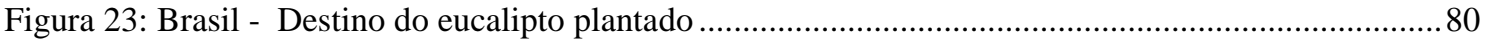

Figura 24: Área plantada de eucalipto no Brasil até 2002 .................................................................81

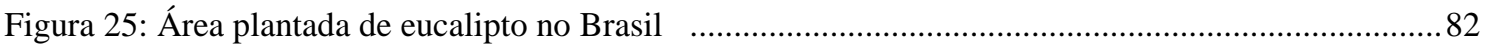


Figura 26: Projeção da área de eucalipto destinada à produção de carvão vegetal. Fonte: SBS, 2009 ......84

Figura 27: Projeção da venda de créditos de carbono originado da área de eucalipto destinada à produção

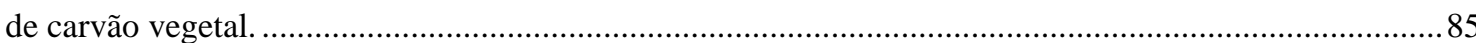



Figura 29: Percentual da área da silvicultura por Estados da federação - Brasil. ....................................88

Figura 30: Setores econômicos atendidos pela produção da silvicultura no Brasil. ...............................89

Figura 31: Exemplo de uma redução de GEE de um projeto de MDL em um aterro sanitário ................ 154

Figura 32: Esquema para entendimento do conceito de adcionalidade .......................................... 155

Figura 33: Prazo para submissão, divulgação e aprovação de projeto de MDL ................................... 166

Figura 34: Prazo para projetos aprovado com ressalvas............................................................ 168

Figura 35: Procedimento para obtenção de Carta de Aprovação em projetos com revisão:..................... 169 


\section{LISTA DE TABELAS}

Tabela 1: Padrões de Consumo de produtos selecionados em países desenvolvidos e em desenvolvimento

Tabela 2: Consumo de Combustíveis e Eletricidade em 1988 (toneladas equivalentes de petróleo) .......... 12

Tabela 3: Concentração de alguns gases causadores do efeito estufa na atmosfera ...............................23

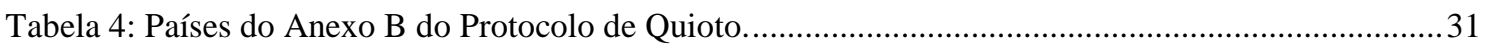

Tabela 5: Distribuição das atividades de projeto no Brasil por tipo de projeto ......................................47

Tabela 6: População, Taxa de Crescimento, Total de Moradias da região de Perus ................................63

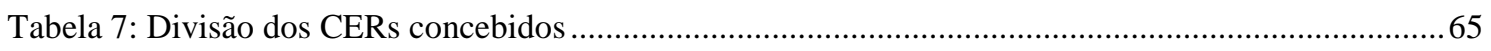

Tabela 8: Participantes do Projeto de MDL do aterro sanitário Bandeirantes .........................................66

Tabela 9: Classificação e Uso do solo nas áreas do projeto Plantar. .....................................................71

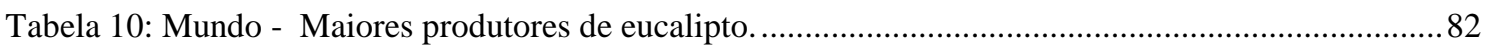

Tabela 11: Taxa de crescimento das plantações de eucalipto nos últimos cinco anos ...........................83

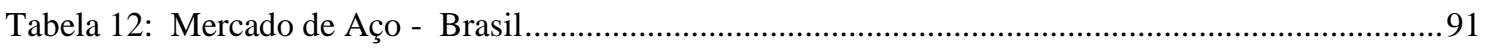

Tabela 13: Flutuação do emprego formal do município de Curvelo- Jan/ 2009 à jun/ 2009................... 141

Tabela 14: Variação dos índices de emprego - Minas Gerais........................................................... 142 
AND Autoridade Nacional Designada

CE Conselho Executivo

CIMGC Comissão Interministerial de Mudança Global do Clima

CIN Comissão Internacional de negociação

CONAMA Conselho Nacional do Meio Ambiente

COP Conferência das Partes

CQNUMC Convenção-quadro das Nações Unidas sobre Mudança do Clima

DCP Documento de Concepção do Projeto

EIA Estudo de Impacto Ambiental

EOD Entidade Operacional Designada

GEE Gases precursores do efeito estufa

GEF Fundo Global para o Meio Ambiente - do inglês Global Environment

Facility

FBMC Fórum Brasileiro de Mudanças Climáticas

IET Comércio Internacional de Emissões - do inglês International

Emission Trading

IPCC Painel Intergovernamental de Mudanças Climáticas - do inglês

Intergovernamental Panel on Climate Change 
JI Implementação Conjunta - do inglês Joint Implementation

LULUCF Uso da terra, mudança no uso da terra e florestas - do inglês Land

Use, Land Use Change and Forestaition

MCT Ministério da Ciência e Tecnologia

MDL Mecanismo de Desenvolvimento Limpo

MMA Ministério do Meio Ambiente

MOP Reunião das Partes - do inglês Meeting of Parties

OMC Organização Mundial do Comércio

OMM Organização Meteorológica Mundial

ONU Organização das Nações Unidas

PDD Documento de concepção do projeto - do inglês Project Design

Document

PNMA Lei da Política Nacional do Meio Ambiente

PNUMA Programa das Nações Unidas para o Meio Ambiente

RCE Redução Certificada de Emissões

RIMA Relatório de Impacto Ambiental

RSU Resíduos Sólidos Urbanos

SBI Órgão Subsidiário de Implementação - do inglês Body for

Implementation

SBSTA Órgão Subsidiário de Assessoramento Científico e Tecnológico - do 
inglês Subsidiary Body for Scientific and Technological Advice

UE União Européia

UNFCCC Convenção-Quadro das Nações Unidas sobre Mudança do Clima -

do inglês United Nations Framework Convention on Climate Change

UTB Usina Temelétrica Bandeirantes 


\section{Sumário}

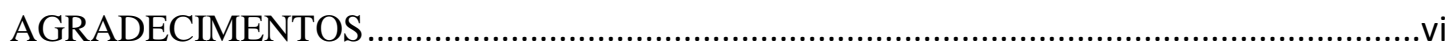

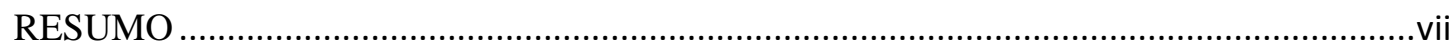

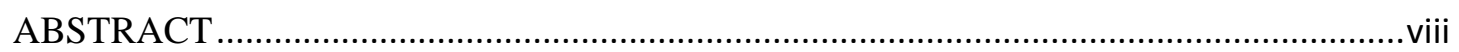

LISTA DE ILUSTRAÇÕES .................................................................................

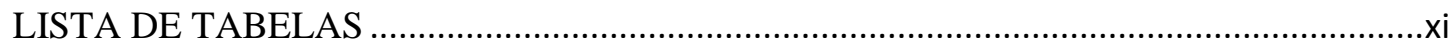

LISTA DE ABREVIATURAS E SIGLAS .......................................................................ii

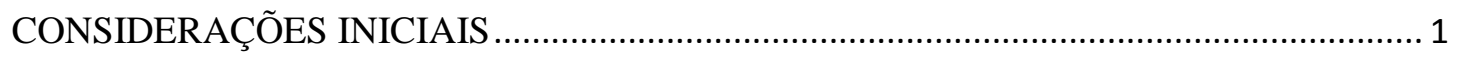

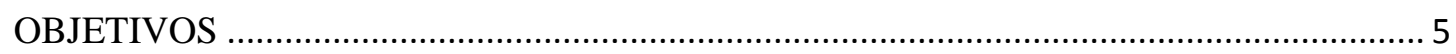

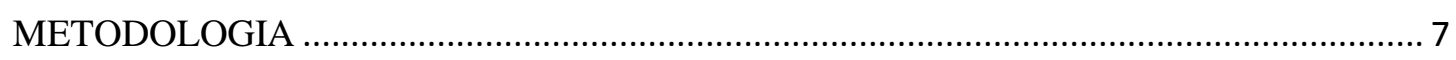

CAPÍTULO I - A CRISE AMBIENTAL E A SUSTENTABILIDADE ............................. 9

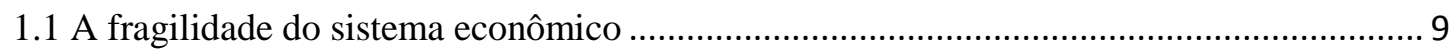

1.2 A percepção sistêmicas dos problemas ambientais ........................................................ 13

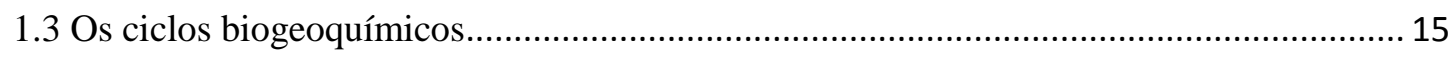

1.5 A questão climática: As emissões de $\mathrm{CO}_{2}$ e o efeito estufa. ............................................. 20

1.6 A Convenção-Quadro das Nações Unidas Sobre a Mudança do Clima............................ 27

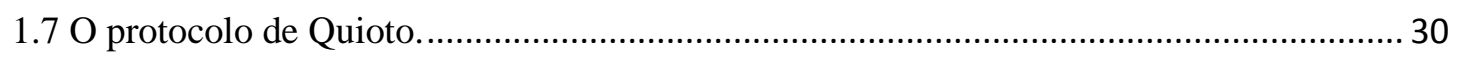

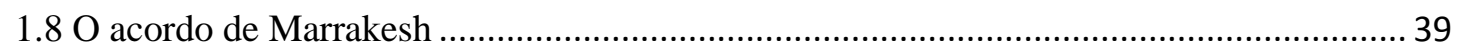

CAPÍTULO II - O MECANISMO DE DESENVOLVIMENTO LIMPO ....................... 42

2.1 Conceito de Mecanismo de Desenvolvimento Limpo (MDL) ........................................ 42

2.2 Dados preliminares de MDL no Brasil e no Mundo ........................................................ 44

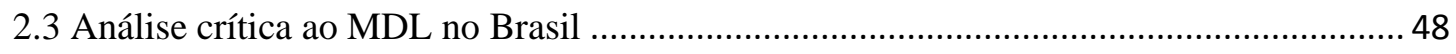




\section{CAPÍTULO III - ESTUDO DE CASO: ANÁLISE DE PROJETOS DE MDL EM}

3.1 Breve relato da política pública de resíduos sólidos no Brasil ......................................... 52

3.2 Caracterização do projeto MDL do Aterro Sanitário Bandeirantes .................................. 56

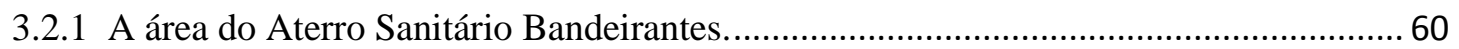

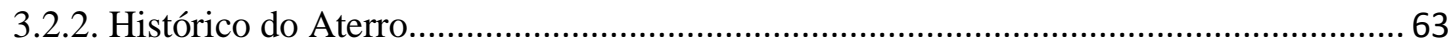

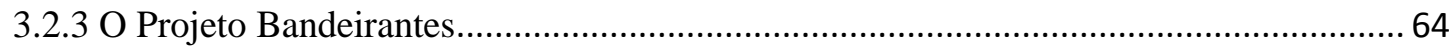

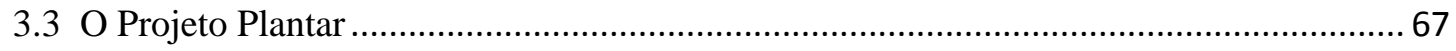

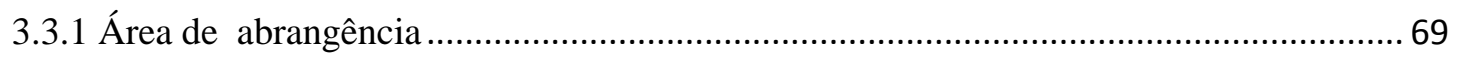



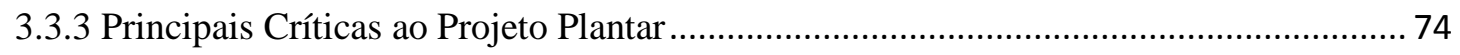

CAPÍTULO IV - ANÁLISE DA MONOCULTURA DE SILVICULTURA ................... 78

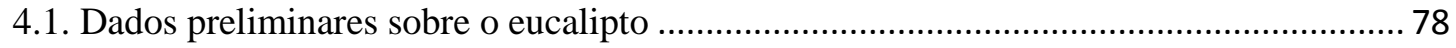

4.2 O panorama atual da Silvicultura no Brasil - O eucalipto é a resolução dos problemas

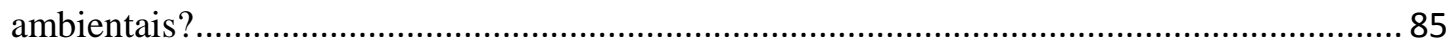

4.3 O mercado de florestas no Brasil e sua sustentabilidade.................................................. 93

4.4 Os problemas ambientais decorrentes da utilização da monocultura de eucalipto............. 98

CAPÍTULO V - ANÁLISE COMPARATIVA DOS PASSIVOS AMBIENTAIS E PRESTAÇÃO DO SERVIÇO AMBIENTAL. ............................................................ 121

5.1 Passivo Ambiental: A monocultura de silvicultura de eucalipto e o aterro sanitário

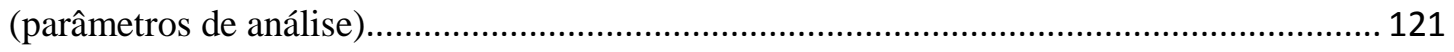

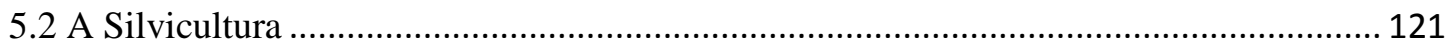

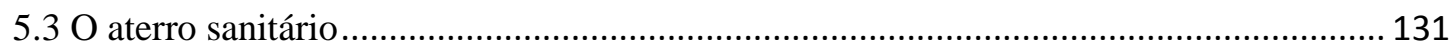




\section{ANEXO I - PROCEDIMENTOS PARA GERAÇÃO DAS REDUÇÕES}

CERTIFICADAS DE EMISSÕES - RCEs 150

A. Geração das Reduções Certificadas de Emissão - RCEs 150

A.1 Os critérios de elegibilidade 150

A.2 Os critérios de sustentabilidade. 158

A.3 Ciclos do Projeto de MDL 159

REFERÊNCIAS BIBLIOGRÁFICAS 173 


\section{CONSIDERAÇÕES INICIAIS}

A virada do milênio, tem sido marcada por grandes transformações, ocasionando mudanças de paradigmas, no que tange às estruturas sociais, comportamentos e valores.

Uma implantação tecnológica e contínua, a partir da evolução da microeletrônica, da informática, das telecomunicações, das biotecnologias e da utilização de novos materiais, favorece a crescente globalização transnacional dos mercados (PAULA, 1997).

Em contrapartida, o que se verifica é o aumento do individualismo, os conflitos de forma generalizada (tanto no campo étnico, social, religioso), o desemprego e principalmente a ampliação do abismo entre ricos e pobres.

A tão enaltecida globalização, que encurta a distância e dinamiza os fluxos de mercadorias, serviços e pessoas, traz consigo uma característica paradoxal, qual seja: a fragmentação global. Fragmentação esta que é o resultado do acúmulo de capitais às custas da exploração desenfreada dos recursos naturais e da mão de obra.

De forma geral, os problemas anteriormente mencionados convergem para a questão ambiental, devendo ser entendidos, por sua vez, como problemas sistêmicos, interligados e interdependentes, que integram uma mesma e grave crise de percepção (CAPRA, 1997).

Em outras palavras, os seres humanos não conseguem enxergar a conectividade de suas interferências antrópicas no meio e quando ao menos consegue identificar um determinado impacto, o faz de forma localizada e sem a devida interdependência com outras ações.

Disto decorre a fragilidade de nosso atual modelo econômico de desenvolvimento baseado única e exclusivamente na visão de mundo analítica cartesiana mecanicista e na física newtoniana, que concebem o universo como uma máquina cujos fenômenos somente podem ser adequadamente compreendidos quando fragmentados em partes definidas (CAPRA, 1997). 
O que se vê, portanto, é que o modo de produção econômico capitalista é essencialmente paradoxal, uma vez que não respeita a capacidade de suporte dos aportes naturais, tanto na obtenção de matérias-primas, quanto no descarte dos resíduos no meio ambiente.

Da mesma forma, não pensa na manutenção do próprio sistema, já que precisa necessariamente dos recursos naturais para alimentar novamente o sistema produtivo.

O Homem, por meio de sua visão antropocêntrica, ignora a capacidade de suporte dos sistemas naturais, interferindo, nos diversos fluxos ecológicos, causando mudanças imprevisíveis e em muitos casos totalmente irreversíveis (BOFF, 2004).

Essa visão antropocêntrica, utilitarista e reducionista do ambiente enaltece a humanidade como ente acima dos sistemas naturais e parte isolada e de controle dos mesmos. Os Homens continuam a se sentir acima de todas as coisas e de todos os seres com os quais compartilhamos o planeta, e agir como se fôssemos o centro do universo e o ápice do processo evolutivo (BOFF, 2004).

O fato é que as interferências humanas estão sendo sentidas pela sociedade de forma generalizada e globalizada. Ao contrário da globalização econômica, que fragmenta o sistema social, as respostas naturais são socializadas para todos os habitantes do planeta.

A atividade econômica humana tem alterado de forma significativa o balanço energético terrestre. Quando os processos industriais queimam combustíveis fósseis são liberadas gigantescas quantidades do $\mathrm{CO}_{2}$ na atmosfera. Nas queimadas florestais o processo se repete, havendo a liberação de $\mathrm{CO}_{2}$ que estava aprisionado no bioma. Nas atividades de pecuária e agricultura o mesmo acontece com outros gases de efeito estufa (metano e óxido nitroso, dentre outros). 
Tais alterações afetam de forma direta e indireta os ciclos biogeoquímicos, que são os pilares de sustentação dos sistemas naturais do planeta. $\mathrm{O}$ ciclo que está diretamente relacionado a esse processo é o ciclo do carbono.

Apesar dos impactos climáticos decorrentes do aumento da concentração do $\mathrm{CO}_{2}$ na atmosfera serem controversos, muitos cientistas aceitam a tese de que a duplicação da concentração do gás na atmosfera em relação ao nível pré-industrial pode ocasionar várias alterações ambientais sérias (IPCC, 1996).

Os cenários energéticos realizados pelo IPCC - International Pannel on Climate Change (IPCC, 1996) estabelecem previsões pessimistas, mostrando que se não forem adotadas reduções nas emissões de gases de efeito estufa (GEE), as emissões globais de $\mathrm{CO}_{2}$ para a atmosfera irão aumentar de 7,4 GtC/ano em 1997 para aproximadamente 26 GtC/ano em 2.100.

Nesse contexto, surge a necessidade de se criar mecanismos que estimulem as discussões sobre o tema e que incentivem as reduções de emissões dos GEE. A assinatura do Protocolo de Quioto foi o ponto de partida para o estabelecimento de metas internacionais de reduções de GEE, que são fundamentais pilares para a criação de um mercado de carbono.

O Protocolo de Quioto é um tratado internacional, ratificado em 15 de março de 1998, que tem como objetivo central a redução das emissões de gases poluentes, denominados GEE. O documento entrou oficialmente em vigor no dia 16 de fevereiro de 2005 , após ter sido discutido e negociado em 1997, na cidade de Quioto.

Os países que ratificaram tal instrumento tem a obrigatoriedade de redução em 5,2\%, à emissão de gases poluentes, entre os anos de 2008 e 2012 (primeira fase do acordo).

Sinteticamente, o acordo traz à baila três "mecanismos de flexibilidade" que permitem os países membros cumprir com as exigências de redução de emissões, fora de seus territórios. Dois desses mecanismos correspondem somente a países do Anexo I (países desenvolvidos) desse tratado: a Implantação Conjunta (Joint Implemention) e o Comércio de Emissões 
(Emission Trading); o terceiro, o Mecanismo de Desenvolvimento Limpo-MDL (Clean Development Mechanism), permite atividades entre o Norte e o Sul, com o objetivo de apoiar o desenvolvimento sustentável.

O Protocolo de Quioto é um "Mercado Regulado", também chamado Compliance, no qual os países possuem metas de reduções a serem cumpridas de forma obrigatória. Nesse mercado após um projeto de MDL obter reduções certificadas de emissão (RCE) tais títulos podem ser comercializados em bolsa de valores ou contratos firmados entre as partes interessadas.

Ainda existe um Mercado Voluntário, onde empresas, ONGs, instituições, governos, ou mesmo cidadãos, tomam a iniciativa de reduzir as emissões voluntariamente. Os créditos de carbono (VERs - Verified Emission Reduction) podem ser gerados em qualquer lugar do mundo e são auditados por uma entidade independente do sistema das Nações Unidas, não valendo como redução de metas dos países.

O destaque para esses créditos é que são menos burocráticos e podem ser eleitos outros mecanismos de redução para a obtenção desses. O principal mercado é o Chicago Climate Exchange, nos EUA.

Além dos mercados apresentados tem-se também os chamados Fundos Voluntários que não fazem parte do mecanismo de mercado, ou seja, não geram crédito de carbono, sendo que o valor da doação não pode ser descontado da meta de redução dos países doadores. Os principais Fundos são o "Forest Carbon Partnership Facility", do Banco Mundial e o Fundo Amazônia, do governo brasileiro.

Cabe ser ressaltado que o presente trabalho se limitará a análise do mecanismo contido no Protocolo de Quioto. 


\section{OBJETIVOS}

A promoção do desenvolvimento sustentável é condição de elegibilidade para quaisquer candidaturas a créditos de carbono, em outras palavras, qualquer empresa que queira obter créditos de carbono necessita ajustar sua produção a critérios mínimos de sustentabilidade.

Conceitualmente, desenvolvimento sustentável é aquele que contempla às presentes gerações sem comprometer a possibilidade de as gerações futuras atenderem às suas próprias necessidades e integrando três pilares fundamentais: ambiental, social e econômico.

Diante da publicidade notória da percepção que os recursos naturais são esgotáveis e que, por conseguinte, há necessidade de que seja estabelecido um equilíbrio entre as ações humanas e a preservação/conservação do meio ambiente torna-se imprescindível a busca pelo alcance do desenvolvimento sustentável do planeta.

O Homem coloca em risco sua própria existência quando configura sua estrutura linear de desenvolvimento com base na retirada de recursos naturais e queima de combustíveis fósseis como carvão e petróleo desde a Revolução Industrial no século XVIII.

É nesse contexto que se estabelecem tratados internacionais como a Convenção do Clima e o Protocolo de Quioto com a finalidade de alcançar o desenvolvimento sustentável por meio do mecanismo de desenvolvimento limpo, denominado de MDL.

Projetos do MDL geram a possibilidade de trazer uma grande quantidade de benefícios de ordem local e regional. Isso inclui benefícios ambientais, sociais e econômicos como água e ar mais limpos, geração de empregos, redução da pobreza, diminuição do desmatamento e da perda da biodiversidade, aporte de capital estrangeiro, e o acesso a tecnologias "verdes". 
Ampla é a variedade e quantidade de estudos sobre a temática das reduções de emissões de $\mathrm{CO}_{2}$ e mercado de carbono, entretanto o presente estudo visa dar uma visão generalizada de como se obter as RCE (Redução Certificada de Emissões)e discutir a eficácia real dos créditos de carbono obtidos a partir de projetos de reflorestamento com silvicultura e utilização do gás metano em aterros sanitários comparando-os e analisando a prestação do serviço ambiental em escala local e regional. 


\section{METODOLOGIA}

Este trabalho está baseado em revisão bibliográfica, realizada em livros, artigos, documentos técnicos nacionais e internacionais, e em análises críticas das informações obtidas.

Dessa forma, a pesquisa terá seus referenciais baseados na metodologia de pesquisa qualitativa. Cabe ser ressaltado que nas pesquisas do tipo qualitativa se utilizam uma grande variedade de procedimentos e instrumento de coleta de dados, destacando-se a análise de documentos e outras técnicas.

Para que se possam alcançar os objetivos da presente proposta de pesquisa, serão propostos os seguintes procedimentos metodológicos:

- Levantamento e revisão bibliográfica:

Foi realizada uma revisão bibliográfica sobre os principais temas relacionados à pesquisa, com o objetivo de confrontar dados e coletar de dois projetos distintos de MDL, realizados no Brasil:

A) Usina Termelétrica Bandeirantes UTB (Aterro Sanitário Bandeirantes), localizada no município de São Paulo - SP. Para isso realizou-se levantamento de dados bibliográficos e análise da promoção da sustentabilidade ambiental em decorrência da obtenção de créditos de carbono.

B) Projeto de MDL de reflorestamento denominado Projeto Plantar, localizado na região central do Estado de Minas Gerais. Necessário, portanto, levantamento de 
dados bibliográficos e análise da promoção da sustentabilidade ambiental em decorrência da obtenção de créditos de carbono.

- Análise dos dados obtidos e comparação entre os projetos de MDL

Nessa parte específica do trabalho tem-se o confronto dos passivos ambientais de ambos os projetos. 


\section{CAPÍTULO I - A CRISE AMBIENTAL E A SUSTENTABILIDADE}

1.1 A fragilidade do sistema econômico

Comparando a idade do planeta Terra (cerca de 4,5bilhões de anos) com o tempo de existência humana (em torno de 100 a 120 mil anos), verifica-se que esta última se constitui em um dos mais recentes capítulos da história evolutiva de nosso planeta. Nessa curta jornada o Homem sempre interagiu com o meio que o circunda, utilizando e modificando os recursos naturais disponíveis (CAPRA, 1997).

Como qualquer outra espécie que habita o planeta, o Homem manteve, de uma maneira genérica (evidente que ocorreram impactos com o advento da agricultura), um equilíbrio com os ecossistemas naturais que integrava, até meados do século XVIII.

Desse ponto em diante, as transformações humanas passaram a ser significativas e impactantes aos demais ecossistemas (desenvolvimento da indústria como, por exemplo, a utilização de carvão e petróleo) limitando, inclusive, o próprio desenvolvimento da atividade econômica humana, uma vez que as próprias atividades entram em processo constante de impacto com a natureza, pondo em risco o próprio modelo de desenvolvimento projetado.

Indubitavelmente as questões de organização econômicas estão relacionadas com as dimensões ambientais, haja vista que o condicionamento ecológico, representado pela finitude dos fluxos de matéria e energia da Terra, regula tudo o que o ser humano faz e pode fazer para a satisfação de suas necessidades (CAVALCANTI, 1996).

Para corroborar com o pensamento anteriormente ventilado se destaca as lições de (ROHDE, 1994) que demonstra a insustentabilidade do sistema econômico, baseada em quatro fatores básicos: crescimento populacional, depleção dos recursos naturais, contemplação de sistemas produtivos que utilizam tecnologias poluentes de baixa eficácia energética atrelada a um sistema de valores que propicia a expansão ilimitada do consumo material. 
Essa posição contraria a lógica econômica capitalista que apenas considera o fluxo das atividades não se preocupando com as fontes ou até mesmo os rejeitos por ele produzidos.

Ainda, destaca o autor, em outro fragmento, o posicionamento da teoria econômica vigente que prevê a acumulação cada vez mais rápida de materiais, energia e riqueza gerando a modificação dos ciclos biogeoquímicos fundamentais destruindo os sistemas de sustentação da vida. (ROHDE, 1994)

Dessa forma a transição desse mundo desintegrado para um em que o desenvolvimento seja sustentado (com sua implícita melhoria da qualidade de vida) exige radical migração da situação presente de insustentabilidade planetária para outro modelo civilizatório (ROHDE, 1994).

O conceito desenvolvimento sustentável sinaliza uma alternativa às teorias e aos modelos tradicionais do desenvolvimento, desgastadas numa série infinita de frustrações.

Na realidade, o sistema econômico deve ser entendido como um subsistema do sistema ecológico e a ele subordinado. Dessa forma, o sistema econômico tradicional do século XX apresenta sinais incontestáveis de fragilidade, pois ultrapassa os limites suportados pelos sistemas naturais (CAPRA, 1997).

A prova cabal da fragilidade do sistema econômico, é o estilo de vida dos denominados países desenvolvidos. Nesses países temos um padrão de consumo exacerbado, embasado no chamado padrão de qualidade de vida.

A discrepância entre países do hemisfério norte e sul pode ser vista em números e estatísticas. De acordo com o Relatório sobre Desenvolvimento Humano, o fluxo líquido de recursos do sul para o norte foi de 239 bilhões de dólares entre 1984 e 1989, bem como o protecionismo dos países desenvolvidos na agricultura custa cerca de 100 bilhões de dólares anuais aos países menos favorecidos (UNDP,1991). 
Podemos ainda chamar atenção para o abismo entre os países desenvolvidos e subdesenvolvidos, emergentes do globo quando comparamos o consumo per capita de materiais e energia, ficando evidente que os padrões de consumo dos países industrializados não podem ser sustentado a longo prazo e muito menos estendidos ao resto do mundo (SACHS, 1994) (Tabelas 1 e 2) .

Tabela 1: Padrões de Consumo de produtos selecionados em países desenvolvidos e em desenvolvimento

\begin{tabular}{|c|c|c|c|c|c|c|}
\hline \multirow[t]{2}{*}{ Produtos } & \multirow[t]{2}{*}{ Ano } & \multirow[t]{2}{*}{$\begin{array}{c}\text { Total } \\
\text { Mundial }\end{array}$} & \multicolumn{2}{|c|}{$\begin{array}{c}\text { \% de Participação } \\
\text { Mundial }\end{array}$} & \multicolumn{2}{|c|}{$\begin{array}{c}\text { Consumo } \\
\text { Per Capita (kg) }\end{array}$} \\
\hline & & & Des. & Em Des. & Des. & Em Des \\
\hline Cereais & 1987 & 1801.33 & 47.6 & 52.4 & 716.7 & 246.6 \\
\hline Leite & 1987 & 532.88 & 71.7 & 28.3 & 319.2 & 39.4 \\
\hline Carne & 1987 & 113.51 & 63.8 & 36.2 & 60.6 & 10.7 \\
\hline Toras & 1988 & 2410.15 & 45.5 & 54.5 & 887.6 & 338.6 \\
\hline Tábuas & 1988 & 337.99 & 77.9 & 22.1 & 213.2 & 19.2 \\
\hline Papel & 1988 & 223.69 & 81.3 & 18.7 & 147.8 & 10.6 \\
\hline Cobre & 1987 & 10.35 & 85.5 & 14.5 & 7.4 & 0.4 \\
\hline Ferro e Aço & 1987 & 699.14 & 80.2 & 19.8 & 469.3 & 36.1 \\
\hline Alumínio & 1987 & 21.63 & 85.6 & 14.4 & 15.5 & 0.8 \\
\hline Automóveis & 1986 & 370.2 & 91.5 & 8.5 & 0.283 & 0.012 \\
\hline $\begin{array}{l}\text { Veículos } \\
\text { Comerciais }\end{array}$ & 1986 & 105.2 & 85.1 & 14.9 & 0.075 & 0.006 \\
\hline $\begin{array}{l}\text { Des. - países } \\
\text { Em Des. - pa } \\
\text { Fonte: Adap } \\
\text { Pesquisa e D }\end{array}$ & $\begin{array}{l}\text { senvolv } \\
\text { sem de } \\
\text { do Re } \\
\text { avolvin }\end{array}$ & $\begin{array}{l}\text { los. } \\
\text { envolvime } \\
\text { ário pre } \\
\text { nto da În }\end{array}$ & $\begin{array}{l}\text { Io pe } \\
\text { Boml }\end{array}$ & tetari & CNU & . 101 \\
\hline
\end{tabular}

É de fácil percepção que o consumo dos países em desenvolvimento é desproporcional ao dos países desenvolvidos. Dessa forma temos a drenagem dos recursos naturais para esses pontos do planeta, em detrimento da grande maioria dos habitantes do globo que não possuem condições mínimas de sobrevivência como o acesso a água potável e alimentos, moradia, higiene dentre outras.

Pode-se chamar atenção que a desproporção se dá desde produtos primários como cereais, leite e carne até mais elaborados como bens de consumo duráveis. 
Tabela 2: Consumo de Combustíveis e Eletricidade em 1988 (toneladas equivalentes de petróleo)

\begin{tabular}{llcccc}
\hline \multicolumn{1}{c}{ Item } & \multicolumn{1}{c}{$\begin{array}{c}\text { Total Mundial } \\
(\mathbf{M M})\end{array}$} & \multicolumn{2}{c}{$\begin{array}{c}\text { \% de Participação } \\
\text { Mundial }\end{array}$} & \multicolumn{2}{c}{$\begin{array}{c}\text { Consumo Per Capita } \\
(\text { Kg) }\end{array}$} \\
\hline $\begin{array}{l}\text { Combustíveis Sólidos } \\
\begin{array}{l}\text { Combustíveis } \\
\text { Líquidos }\end{array}\end{array}$ & 2309.12 & Des. & Em Des. & Des. & Em Des. \\
Diesel & 2745.65 & 66.3 & 33.7 & 1278.3 & 198.9 \\
Gasolina & $(756.67)$ & 75.1 & 24.9 & 1719.6 & 174.6 \\
Gás & $(725.5)$ & 71.6 & 28.4 & $(452.5)$ & $(54.9)$ \\
Eletricidade & 1611.35 & 81.9 & 18.1 & $(495.8)$ & $(33.6)$ \\
Total & 343.13 & 85.2 & 14.8 & 1146.5 & 60.8 \\
\hline
\end{tabular}

Des. - países desenvolvidos.

Em Des. - países em desenvolvimento

Fonte: Adaptado do Relatório preparado para a secretaria da CNUMAD pelo Instituto Indira Gandhi de Pesquisa e Desenvolvimento da Índia, Bombaim.

E quando realizamos uma análise no tocante ao consumo de combustíveis e eletricidade percebemos que a diferença de consumo chega a ser de no mínimo quase dez vezes entre os desenvolvidos e aqueles que estão marginalizados.

Ainda que o sistema econômico fosse baseado na ideia de distribuição de renda em massa, coisa que não o é estaríamos diante de um grande dilema a ser enfrentado: ao enquadrarmos o sistema econômico tradicional sob a perspectiva do consumo aos referidos marginais (habitantes) desse sistema, ocasionaríamos uma expansão econômica global, levando a necessidade de uma maior utilização de recursos naturais, para atender ao padrão de qualidade de vida dessa sociedade de consumo, que por sua vez ocasionariam maiores impactos ambientais.

Ou seja, o sistema econômico é concebido de forma anacrônica, não respeitando as condições naturais de obtenção dos recursos e disposição adequada de seus rejeitos. Assim, mesmo que houvesse uma equidade socioeconômica entre os habitantes do planeta, esbarraríamos na questão dos impactos ambientais, que em última análise seria o fator limitante do acesso ao tão desejado padrão de qualidade de vida (países desenvolvidos). 
Nessa perspectiva recorre-se à indagação, sobre a contradição inerente aos modos de produção que vieram se consolidando - preservação dos recursos naturais face à_demanda crescente por produtos de transformação destes recursos. (CAPRA, 1997)

Sendo assim, temos a aceitação de um discurso ecológico da necessidade de mudança ou transformação do sistema produtivo concebido. Entretanto, a dúvida que paira sobre tal problemática é a seguinte: o sistema capitalista concebido hoje comporta tal mudança?

Mesmo estando no centro do discurso ambientalista, a questão da sustentabilidade ainda não se constitui em consenso conceitual e sequer se questiona como poderia se enquadrar no cenário econômico atual (STAHEL,1994).

Daí a necessidade do enfrentamento das questões: Desenvolvimento significa necessariamente crescimento? Em que ponto efetivamente estamos na linha de desenvolvimento? Será que existe linearidade no desenvolvimento?

1.2 A percepção sistêmicas dos problemas ambientais

A virada do milênio tem sido marcada por grandes transformações, ocasionando uma nova discussão e mudanças de paradigmas, no que tange as estruturas sociais, comportamentos e valores.

Com a queda do sistema socialista e o fim do Welfare State, bem como a substituição do modelo fordista por estruturas flexíveis de produção, baseadas em novos métodos de gerenciamento de fluxos e estoques e do emprego da mão de obra, bem como os novos adventos tecnológicos, a partir da evolução da microeletrônica, da informática, das telecomunicações, das biotecnologias e da utilização de novos materiais, tudo isso favorece a crescente globalização transnacional dos mercados (PAULA, 1997). 
Em contrapartida, acentua-se o individualismo, os conflitos de forma generalizada (tanto no campo étnico, racial, social, religioso), o desemprego e principalmente o abismo entre ricos e pobres.

A globalização, que encurta as distâncias, dinamiza os fluxos de mercadorias, serviços e pessoas e traz consigo uma característica paradoxal qual seja: a fragmentação global, que é o resultado do acúmulo de capitais disseminando miséria e pobreza absoluta.

Se reforce aqui novamente a carência de nosso atual modelo econômico de desenvolvimento baseado única e exclusivamente na visão de mundo analítica cartesiana mecanicista e na física newtoniana, que concebem o universo como uma máquina cujos fenômenos somente podem ser adequadamente compreendidos quando fragmentados em partes definidas (CAPRA, 1997).

O planeta Terra deve ser analisado como um organismo vivo, sendo suas características ligadas entre si, compondo um sistema, que não deve ser interpretado pela soma de seus componentes, mas sim pela interação e interdependência entre eles, que estão em constante evolução. Tudo está estreitamente ligado em nosso planeta, havendo, por conseguinte, um equilíbrio tênue entre tais ligações, bem como a característica cíclica da retroalimentação desses sistemas.

Importante frisar-se que todos os organismos na natureza produzem resíduos, mas o que constituí resíduo para uma espécie é considerado alimento para outra, havendo um constante equilíbrio sem resíduos (LOVELOCK, 2006).

Portanto, o modo de produção econômico é essencialmente paradoxal, uma vez que não respeita a capacidade de suporte dos aportes naturais, tanto na obtenção de matérias-primas, quanto no descarte dos resíduos no meio ambiente. Da mesma forma não propõe a manutenção do próprio sistema, já que precisa necessariamente de mais recursos naturais para alimentar o sistema produtivo. 
Todo sistema terrestre tem a capacidade de suportar determinadas perturbações. Entretanto, tal capacidade tem seus limites e estão sendo excedidos pelo modo de produção linear industrial conhecido atualmente.

Em outras palavras, o Homem, por meio de sua visão antropocêntrica, ignora a capacidade de suporte dos sistemas naturais, interferindo, veementemente, nos diversos fluxos ecológicos, causando mudanças imprevisíveis (ou propositalmente ignoradas) e em muitos casos totalmente irreversíveis.

Essa visão antropocêntrica, utilitarista e reducionista do ambiente enaltece a humanidade como ente acima dos sistemas naturais e parte isolada e de controle dos mesmos. Os Homens continuam a se sentir acima de todas as coisas e de todos os seres com os quais compartilhamos o planeta, e agir como se fôssemos o centro do universo e o ápice do processo evolutivo (BOFF, 1996).

Sem nenhum posicionamento catastrófico ou até mesmo alarmista, o fato é que tais interferências vem sendo sentidas pela sociedade de forma generalizada e globalizada. E ao contrário da globalização econômica citada anteriormente no início deste tópico, que fragmenta o sistema social, as respostas ambientais são socializadas para todos os habitantes do planeta.

\subsection{Os ciclos biogeoquímicos}

Energia e matéria são conceitos elementares a vida do planeta Terra. Os raios solares proporcionam condições necessárias para que haja síntese de matéria orgânica pelos seres autótrofos e sua decomposição, bem como retorno ao meio como elementos inorgânicos pela ação de microconsumidores heterótrofos (BRAGA, et al, 2005).

Ressalte-se que os elementos essenciais para que os seres vivos participem de ciclos de processos de reciclagem de matéria, recebem o nome de biogeoquímicos. Bio, porque os 
organismos vivos interagem no processo de síntese orgânica e decomposição dos elementos; geo, porque o meio terrestre é a fonte dos elementos, e químicos, porque são ciclos de elementos químicos (BRAGA, et al, 2005).

Os ciclos biogeoquímicos são processos de ordem natural que por mecanismos diversos reciclam vários elementos em diferentes formas químicas do meio ambiente para os organismos, fazendo logo após a dinâmica inversa, trazendo os elementos dos organismos para o meio ambiente. Podem ser entendidos como movimentos cíclicos de transição entre os meios bióticos e abióticos. A biogeoquímica é, portanto, a ciência que estuda a troca ou a circulação de matéria entre os componentes vivos e físico-químicos da biosfera (ODUM, 1971).

Três são os tipos de ciclos biogeoquímicos. Os dois primeiros referem-se ao ciclo dos elementos vitais (macro e micronutrientes) e o último relacionado a um composto vital, a água. (BRAGA, et al, 2005). Assim temos o ciclo hidrológico e os ciclos sedimentares e gasosos. O reservatório dos dois últimos são respectivamente, a litosfera e a atmosfera.

\section{$1.4 \mathrm{O}$ ciclo do carbono}

O elemento carbono (C) é o principal constituinte de tudo o que é orgânico e embora o dióxido de carbono $\left(\mathrm{CO}_{2}\right)$ represente apenas $0,032 \%$ dos gases que compõe a atmosfera, o carbono é um elemento que nos últimos anos tem provocado mudanças profundas em todo o mundo.

O elemento carbono é encontrado na atmosfera na forma de gás originado quase todo ele do processo de respiração dos seres vivos (79\%) pelo qual se completa o que chamamos de "Ciclo do carbono". A seguir as figuras 1 e 2 ilustram o ciclo biogeoquímico do carbono.

O Ciclo do carbono se inicia a partir do momento em que as plantas, ou outros organismos autótrofos, absorvem o gás carbônico da atmosfera e o utilizam na fotossíntese (ou quimiossíntese no caso de alguns organismos) incorporando-o às suas moléculas. 
Por meio da fotossíntese e da respiração o carbono passa de sua fase inorgânica à fase orgânica e volta para fase inorgânica, completando, assim, seu ciclo biogeoquímico (BRAGA, et al, 2005).

Em seguida, o carbono passa para o próximo nível trófico quando os animais herbívoros ingerem as plantas e absorvem parte do carbono incorporado na forma de açúcares.

Uma parcela do carbono fotossintetizado pelas plantas será absorvida pelos organismos decompositores, ou ainda, devolvida diretamente à atmosfera como no caso de uma queimada. Ao ser ingerido pelos animais herbívoros o carbono será devolvido à atmosfera através da respiração ou, também, através da decomposição desses organismos.

A equação da fotossíntese é uma simplificação de um conjunto de aproximadamente 80 a 100 reações químicas. Observe-se dois pontos fundamentais: primeiro a energia solar é armazenada como energia química nas moléculas orgânicas ; segundo, a fixação do carbono em sua forma orgânica indica que a fotossíntese é a base da vida na Terra (BRAGA, et al, 2005).

Figura 1: Esquema simplificado do ciclo do carbono

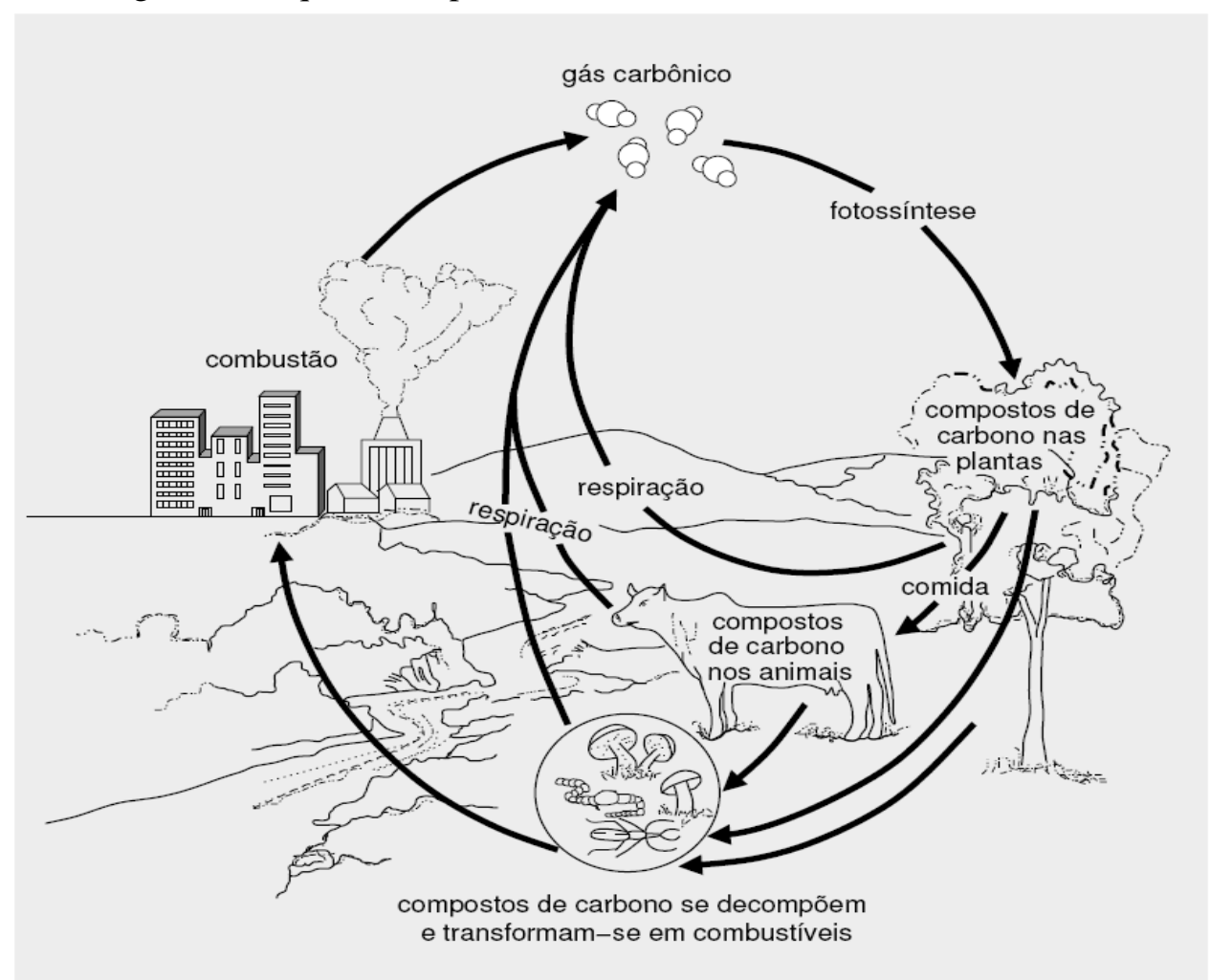

Fonte: CONTI (1998). 
Figura 2: Esquema do ciclo do carbono e seus fluxos

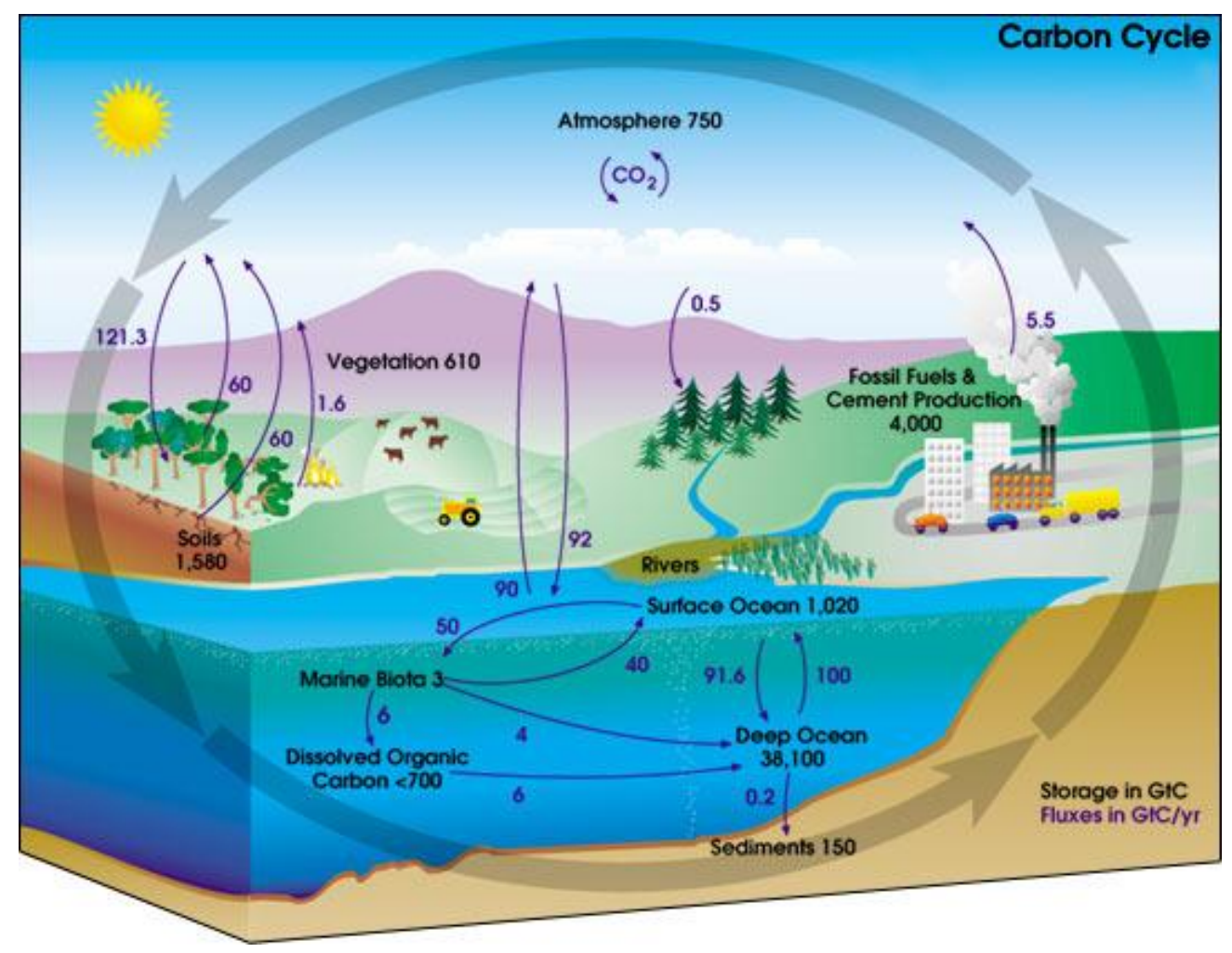

Fonte: NASA, 2006

Percebe-se que a quantidade de carbono fixado no solo sob vegetação nativa, corresponde a aproximadamente $2 / 3$ do total fixado pelo bioma. $\mathrm{O}$ desmatamento permite que uma maior quantidade de radiação incida sobre a superfície do solo, provocando um aquecimento que irá promover a intensificação do processo de mineralização da matéria orgânica - processo denominado de erosão solar.

Cerca de $60 \%$ do carbono do planeta está estocado na crosta terrestre, na forma dos chamados combustíveis fósseis e de rochas sedimentares de origem animal como calcáreas e fosfatadas, e se constituem nos recursos naturais mais pressionados pelos processos produtivos.

Importante ressaltar a existência da interação entre o $\mathrm{CO}_{2}$ atmosférico e o aquático (Figura 2). Os oceanos também são grandes reservatórios de gás carbônico realizando uma troca constante deste com a atmosfera em um processo recíproco e contínuo. A reação química de 
difusão entre os dois importantes reservatórios, cuja direção e intensidade dependem da maior ou menor concentração do gás carbônico (KORMONDY, 1996).

Dessa forma, havendo concentração de $\mathrm{CO}_{2}$ na atmosfera, parte desse $\mathrm{CO}_{2}$ será absorvida pelo oceano, ficando dissolvido na água (BRAGA, et al, 2005). Os ciclos biogeoquímicos não se referem simplesmente a fluxos de matéria, mas também de energia.

O planeta desde sua origem vem vivenciando um processo de entropia crescente: dissipação de energia - resfriamento. O resfriamento do magma, possibilitou a aproximação dos átomos e o estabelecimento de ligações químicas, que passaram a armazenar parte da energia que seria dissipada (movimento anti-entropia). As interações entre atmosfera e litosfera promoveram a ruptura das ligações químicas dos minerais que constituem as rochas - processo de intemperismo, liberando a energia das ligações químicas e solutos que iriam se acumular em última análise, no oceano (entropia crescente).

O solo surge com um novo ajuste, nas relações entre atmosfera e litosfera. Acumulando minerais secundários com elevadas densidades de cargas superficiais, resultantes do processo de intemperismo, o solo passa a reter parte dos solutos que seriam carreados para o sistema de drenagem. $\mathrm{O}$ aumento na concentração de íons no sistema coloidal que constitui o solo irá bloquear os processos de intemperismo químico (movimento anti-entropia). Este equilíbrio solo-atmosfera, tenderia a se romper ao longo do tempo, uma vez que as precipitações atmosféricas promoveriam lixiviação, que redundaria em diminuição na concentração de íons do complexo sortivo e consequente retomada do intemperismo.

O movimento anti-entropia mais significativo ocorrido no planeta é o da biossíntese. Não se trata de conter a dissipação de energia, mas de absorver energia cósmica e armazená-la em compostos de C. Este sistema extremamente eficiente deu origem a biosfera. $\mathrm{O}$ vigor deste sistema não pode ser avaliado somente pelos biomas atuais. Há que se que se considerar os depósitos de combustíveis fósseis e as rochas sedimentares de origem orgânica (calcárias e fosfatadas), que retém mais de $60 \%$ do $\mathrm{C}$ do planeta. 
Além do $\mathrm{C}, \mathrm{H}$ e $\mathrm{O}$, os biomas se valem de grande parte dos íons que seriam lixiviados do solo, na produção da matéria orgânica específica, evitando que a concentração de sais nos oceanos possa vir a ser limitante para a vida.

Muito além das mudanças relacionadas ao efeito estufa, há que se considerar, a partir do carbono fixado na litosfera, que a evolução das espécies foi fortemente marcada pela redução progressiva dos teores de C. Ou seja, mantidas as taxas de elevação dos teores da carbono na atmosfera atuais, estaríamos condenando à extinção uma quantidade incalculável de espécies .

1.5 A questão climática: as emissões de $\mathrm{CO}_{2}$ e o efeito estufa.

O efeito estufa terrestre tem tal denominação por "assemelhar-se" às estufas de plantas, que são projetadas por tetos e paredes de vidro transparente. Tal fato permite a entrada dos raios de solares, bem como o aquecimento do ambiente interno. Mas, sendo uma estufa totalmente lacrada, o calor "entra" no recinto, ali permanecendo, fazendo com que a temperatura interna da estufa seja maior do que a temperatura externa (Figura 3).

Figura 3: Balanço energético global a partir da energia luminosa proveniente do sol.

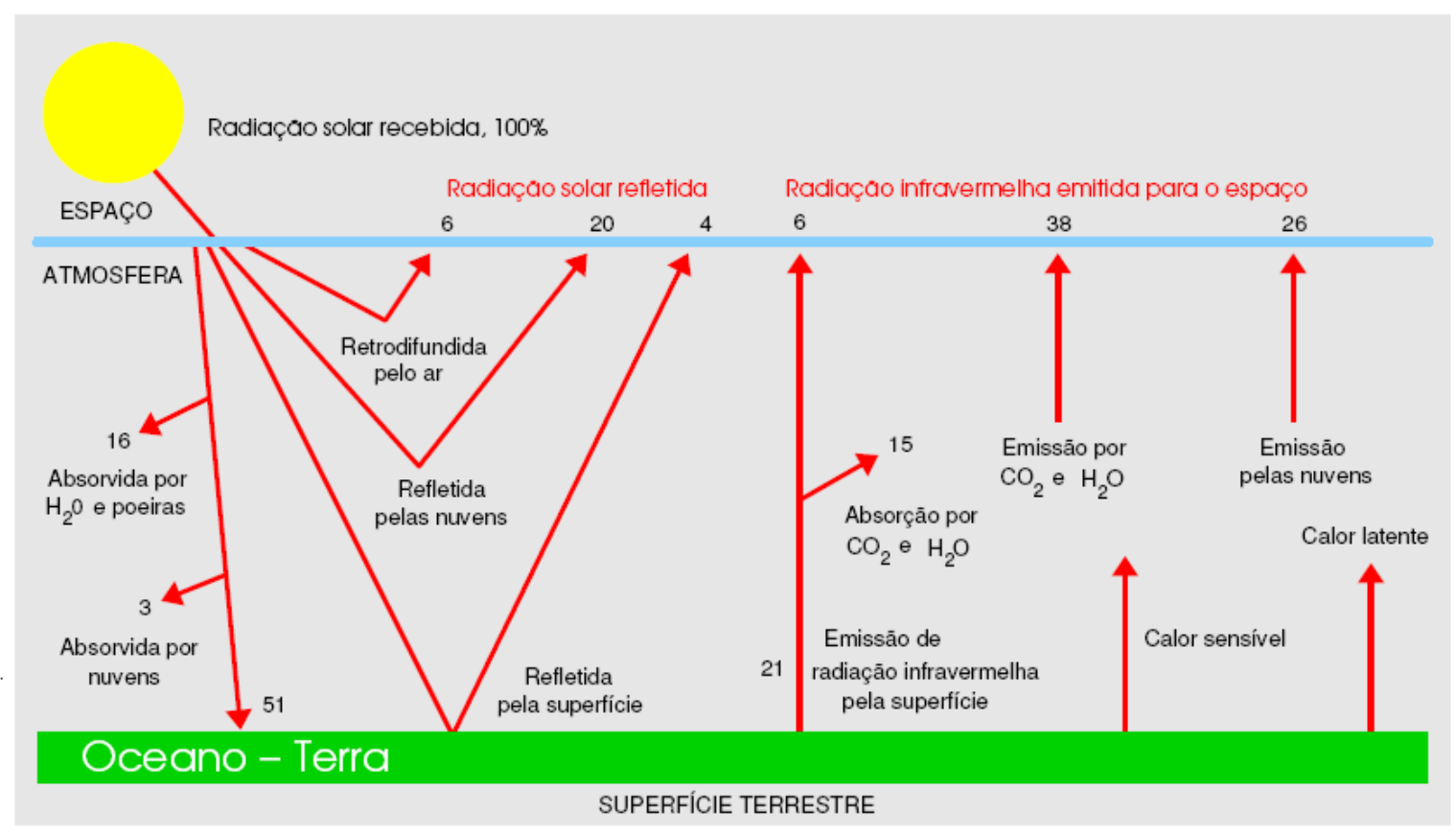

Fonte: Modificado de KIEHL \& TRENBERTH (1997) apud MARTINS (2004). 
Da mesma forma é a atmosfera terrestre. A energia da radiação solar alcança a atmosfera na forma de radiação luminosa. Uma parte desta radiação é refletida pela atmosfera, outra é absorvida por ela e uma terceira parte a atravessa e alcança a superfície terrestre. A superfície, por sua vez, reflete uma parcela da radiação eletromagnética de ondas luminosas e absorve o restante. As radiações absorvidas participam de processos físicos e sua energia transforma-se resultando, ao final, na emissão pela Terra de calor, sob forma de radiação térmica (ondas longas) (GOLDEMBERG, 1998).

A temperatura da Terra é mantida graças a atmosfera que a envolve. Caso não houvesse o efeito estufa, a temperatura da Terra seria muito inferior às registradas hoje (BASTOS \& FREITAS, 1999).

Os gases responsáveis pelo efeito estufa (chamados de gases do efeito estufa - GEE, ou em inglês Greenhouse Gases - GHG) são geralmente compostos de moléculas que se encontram naturalmente na atmosfera e os mais relevantes são: dióxido de carbono $\left(\mathrm{CO}_{2}\right)$; vapor de água $\left(\mathrm{H}_{2} \mathrm{O}\right)$; metano $\left(\mathrm{CH}_{4}\right)$; ozônio $\left(\mathrm{O}_{3}\right)$ e óxido nitroso $\left(\mathrm{N}_{2} \mathrm{O}\right)$, hexafluoreto de enxofre $\left(\mathrm{SF}_{6}\right)$, os clorofluorcarbonos (CFC), representando menos de 1/10 de $1 \%$ da atmosfera, que é composta principalmente de oxigênio $\mathrm{O}_{2}(21 \%)$ e nitrogênio $\mathrm{N}_{2}(78 \%)$.

O vapor d'água é o mais importante gás natural causador do efeito estufa devido à sua abundância. Porém, sua quantidade na atmosfera não é diretamente afetada pela atividade humana. Já o $\mathrm{CO}_{2}$, que é o segundo gás mais importante para o efeito estufa, vem sendo lançado na atmosfera tanto de maneira natural (por exemplo, as atividades dos vulcões) quanto pela ação do homem (por exemplo, os desmatamentos) (UNEP, 2002).

A atividade econômica humana tem alterado de forma significativa o balanço energético terrestre. Quando os processos industriais queimam combustíveis fósseis são liberadas gigantescas quantidades de $\mathrm{CO}_{2}$ na atmosfera, nas queimadas florestais o processo se repete, havendo a liberação de $\mathrm{CO}_{2}$ que estava aprisionado nas árvores. Nas atividades de pecuária e 
agricultura o mesmo acontece com outros gases de efeito estufa (metano e óxido nitroso, dentre outros).

Estima-se que o ciclo natural de carbono na natureza seja de 20 anos. Culturas anuais como a cana, reduzem este ciclo drasticamente. Além disto, o uso de grande quantidade de calcário, para neutralizar a acidez e compensar os efeitos nocivos das altas concentrações de $\mathrm{K}$ presentes no vinhoto utilizado na fertilização, tornam o balanço de $\mathrm{C}$, neste cultivo altamente negativo. Tal alteração afeta substancialmente, de forma direta e indireta, os ciclos biogeoquímicos, que são os pilares de sustentação dos sistemas naturais do planeta.

As elevadas emissões de gases de efeito estufa estão aumentando a capacidade da atmosfera de reter o calor refletido na superfície, perturbando a forma pela qual o clima estabelece seu equilíbrio. Nosso modelo industrial, baseado na utilização intensiva de combustíveis fósseis, e nossas necessidades alimentares crescentes estão, na verdade, engrossando o cobertor que recobre a Terra. Se antes o clima mudava o comportamento dos seres humanos, gerando fenômenos adaptativos ou migratórios, agora são os seres humanos que estão alterando as condições climáticas (CAPRA, 1997).

O nível das alterações de temperatura é extremamente incerto, haja vista que os condicionantes para determinação dessa mudança são os sistemas muito complexos, os oceanos e a atmosfera (TURNER, PEARCE \& BATEMAN,1994). A Tabela 3 mostra a concentração dos gases de efeito estufa na atmosfera antes e depois da Revolução Industrial. 
Tabela 3: Concentração de alguns gases causadores do efeito estufa na atmosfera

\begin{tabular}{|c|c|c|c|c|}
\hline \multirow[b]{2}{*}{ Gás de estufa } & \multicolumn{2}{|c|}{ Concentração } & \multirow[b]{2}{*}{$\begin{array}{l}\text { Taxa anual de } \\
\text { mudança de } \\
\text { concentração }\end{array}$} & \multirow[b]{2}{*}{$\begin{array}{c}\text { Tempo de vida } \\
\text { na atmosfera }\end{array}$} \\
\hline & $\begin{array}{c}\text { Pré-industrial } \\
(1750)\end{array}$ & Após 1998 & & \\
\hline Dióxido de Carbono $\left(\mathrm{CO}_{2}\right)$ & $280 \mathrm{ppm}$ & $365 \mathrm{ppm}$ & $1,5 \mathrm{ppm} /$ ano & 5 a 200 anos \\
\hline Metano $\left(\mathrm{CH}_{4}\right)$ & $770 \mathrm{ppb}$ & $1.745 \mathrm{ppb}$ & $7 \mathrm{ppb} / \mathrm{ano}$ & 12 anos \\
\hline Óxido Nitriso $\left(\mathrm{N}_{2} \mathrm{O}\right)$ & $270 \mathrm{ppb}$ & $314 \mathrm{ppb}$ & $0,8 \mathrm{ppb} /$ ano & 114 anos \\
\hline CFC-11 & Zero & $268 \mathrm{ppt}$ & $-1,4 \mathrm{ppt}$ & 45 anos \\
\hline HFC-23 & Zero & $14 \mathrm{ppt}$ & $0,5 \mathrm{ppt} /$ ano & 260 anos \\
\hline Perflurometanos (CF) & $40 \mathrm{ppt}$ & $80 \mathrm{ppt}$ & $1 \mathrm{ppt} /$ ano & $>50.000$ anos \\
\hline
\end{tabular}

Apesar da discordância de parte minoritária da comunidade científica acerca da utilização da análise química das bolhas de ar contidas nos cilindros de gelo retirado das estações de medição, bem como sobre o aumento da concentração de $\mathrm{CO}_{2}$ atmosférico ser decorrente de causas naturais e não por eventos antrópicos (HIEB \& HIEB, 2006), foi somente pela análise química dessas bolhas aprisionada nos cilindros de gelo (ice core) que se tornou possível a comparação das diferentes concentrações de gases de efeito estufa na atmosfera, desde o último período glacial.

Impactos climáticos decorrentes do aumento da concentração de $\mathrm{CO}_{2}$ na atmosfera são controversos e muitos cientistas aceitam a tese de que a duplicação da concentração do gás na atmosfera em relação ao nível pré-industrial pode ocasionar várias alterações ambientais.

Durante a época glacial a concentração de $\mathrm{CO}_{2}$ era de 200 ppm, elevando-se paulatinamente até 250 ppm 8000 anos atrás, seguido de um aumento de mais 25 ppm nos 7.000 anos seguintes (IPCC, 2000).

Entre o último milênio e o início da revolução industrial, a concentração de $\mathrm{CO}_{2}$ variou entre $275 \mathrm{ppm}$ e $285 \mathrm{ppm}$. Tais alterações ocorreram de maneira progressiva e os índices de oscilação no reservatório atmosférico de carbono, salvo raríssimas exceções, excedeu a poucas gigatoneladas de carbono (GtC) por década. De 1850 a 1998, $270 \mathrm{GtC}$ foram lançadas na 
atmosfera pela queima de combustíveis fósseis e cimento (FRIEDLINGSTEIN, 2001) (Figura 4).

Com o aumento do uso de combustíveis fósseis, elevou-se a concentração do gás carbônico na atmosfera de 280 ppm, na era pré-industrialização, para 365 ppm em 1995 (KEELING \& WHORF, 2005).

Os combustíveis fósseis, como, por exemplo, o petróleo, são frutos da deposição de biomassa acumulada no subsolo, por milhares de anos. A extração bem como a utilização por meio da combustão dessa biomassa acumulada libera o carbono armazenado para a atmosfera em um espaço de tempo muito inferior que o tempo que o carbono atmosférico leva para se transformar em petróleo. O uso de rochas carbonáticas, calcáreo calcítico ou dolomítico, em larga escala, como corretivos do solo, também concorre para liberar para a atmosfera o carbono fixado na crosta terrestre.

Outra fonte de carbono na atmosfera são os desmatamentos e as queimadas que acabam por liberar para a atmosfera o carbono que havia sido fixado pelo processo de fotossíntese. O acúmulo de gás carbônico gasoso na atmosfera se deve, portanto, a diferença entre as escalas de tempo de uso e acúmulo de carbono, provocando uma forte perturbação no ciclo ideal do carbono gerando, por conseguinte, um desbalanceamento do ciclo.

A Figura 4 mostra um esquema dos fluxos globais de carbono, bem como as alterações antropogênicas no ciclo deste elemento, resultantes do aumento no uso de combustíveis fósseis e mudança de padrões de ocupação do solo.

A perda de carbono para atmosfera pode sofrer processo de aceleração com a alteração do uso do solo em uma determinada região. Ou seja, modificar o padrão de cobertura vegetal de uma determinada área por outra altera o comportamento e o ciclo do carbono no solo alongando ou encurtando seu ciclo de aprisionamento. 
Estudos mostram que se o desmatamento na região amazônica for mantido, entre 2 e 5 milhões de hectares ao ano a floresta poderá desaparecer nos próximos 75 anos (ANDREUX \&CERRI, 1989). Dessa forma, a mudança do padrão vegetal ou do uso do solo pode dobrar a perda de carbono para a atmosfera que antes estava estocada no solo e na vegetação.

A opção de modelos lineares de produção e o consumismo generalizados estabelecem uma demanda cada vez maior pela utilização de energia, que em sua grande maioria, está atrelada a queima de combustíveis fósseis havendo, por conseguinte, uma emissão cada vez maior de gases de efeito estufa. Pesquisas revelam que 97\% dos GEE emitidos em 1997, tiveram origem nas nações industrializadas, resultado, principalmente, da queima de combustíveis fósseis, sobretudo para geração de energia e atividades industriais (ANDRADE \& COSTA, 2008).

Das emissões globais de GEE, 23\% são causadas pelo desflorestamento, e a maior parte disso provém de países em desenvolvimento. Só na América Latina, bem mais de dois terços do total de emissões devem-se ao desmatamento/queimadas. Porém, os países têm responsabilidades comuns, mas distintas: somente os Estados Unidos respondem por $21 \%$ do total de emissões mundiais, embora abriguem apenas $4 \%$ da população do planeta. Em contraposição, 136 países em desenvolvimento são responsáveis, coletivamente, por $24 \%$ das emissões globais. (ANDRADE \& COSTA, 2008). 
Figura 4: Alterações antropogênicas no ciclo do carbono resultantes do aumento no uso de combustíveis fósseis e mudança de padrões de ocupação do solo. As setas indicam a magnitude média de perturbação

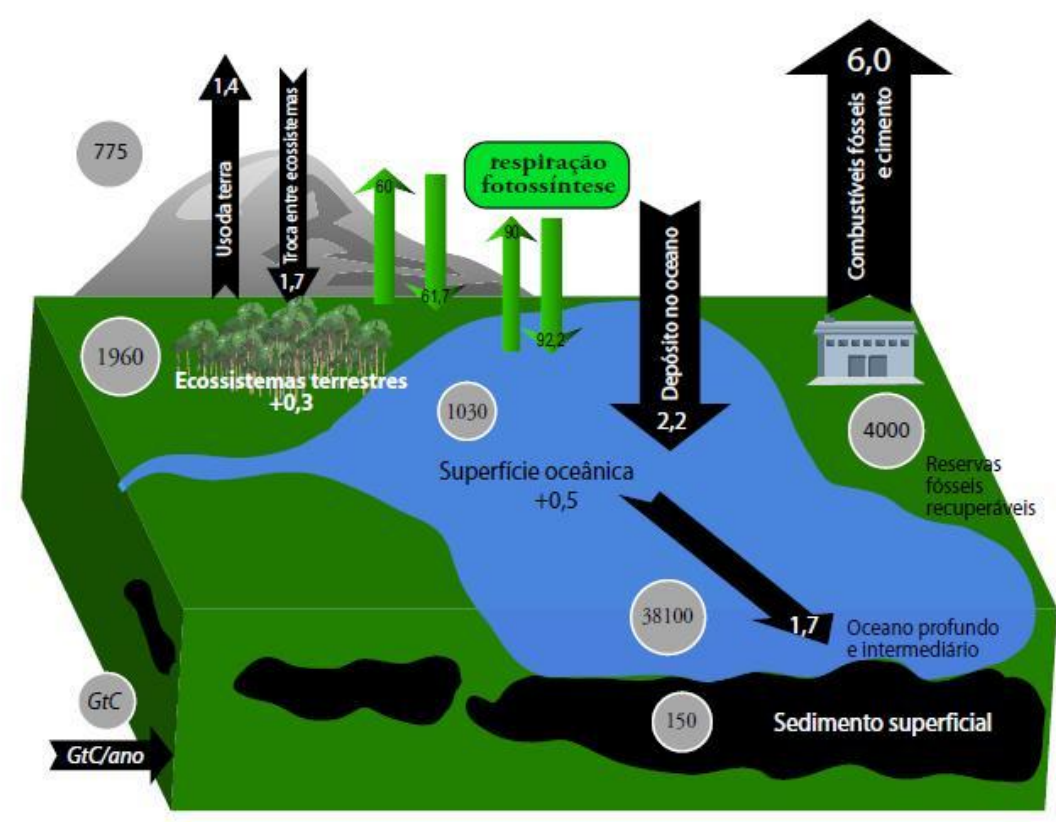

Fonte: Technology Opportunities to Reduce U.S. Greenhouse Gas Emissions, modificado de IPCC (1995).

Entretanto, modelos e cenários climáticos sofisticados indicam que os países também têm vulnerabilidades comuns, porém distintas. A suscetibilidade comparativa a impactos climáticos adversos também se encontra ao longo do eixo Norte-Sul, mas numa relação inversa à responsabilidade histórica. Estudos recentes do provável impacto da mudança climática na produção regional agrícola pressupõem impactos positivos para os Estados Unidos, Japão e partes da Europa, e consideráveis consequências negativas para a África Subssariana e para o subcontinente indiano. Dados de 2001 indicam que os Estados Unidos emitiam 20 toneladas métricas de CO2 per capita/ano, enquanto na Índia, a emissão é de 1,05 toneladas per capita/ano (FISCHER, 2001).

Só para que se possa ter uma ideia da problemática que tange as emissões de $\mathrm{CO}_{2}$ citaremos, brevemente, o caso chinês. A China apresenta um crescimento anual de quase $10 \%$ 
desde a década de 80 . O país tornou-se a terceira maior economia do mundo e tirou quase meio bilhão de pessoas da pobreza. Entretanto, esse processo significou o aumento da poluição num nível que torna insustentável o desenvolvimento chinês no longo prazo (PNUD, 2010).

A expansão chinesa gerou degradações ao meio ambiente. "A emissão total de gasesestufa da China cresceu rapidamente com a industrialização e a urbanização ao longo das últimas décadas. Desde 1970 a 2007, o volume total subiu sete vezes. Em 2007, as emissões de $\mathrm{CO}_{2}$ da China ultrapassaram as dos Estados Unidos e são hoje as maiores do mundo" (PNUD, 2010).

Os chineses lançaram 6 bilhões de toneladas de gases-estufa ao ano, contra 1 bilhão no início dos anos 70. Tratando-se de um país extremamente populoso, apresenta emissões per capita menores que as dos países desenvolvidos — mas deve-se considerar que estas cresceram $381 \%$ no período, bem mais que as do planeta como um todo (17\%), segundo dados da Agência Internacional de Energia (PNUD, 2010).

1.6 A Convenção-Quadro das Nações Unidas Sobre a Mudança do Clima.

As mudanças globais sobre o clima passaram a ter destaque no debate internacional a partir da década de 1970. A precursora do debate moderno e das negociações sobre mudanças climáticas globais foi a histórica Conferência Mundial sobre o Ambiente Humano, em Estocolmo, em junho de 1972. Durante a Conferência, deu-se pela primeira vez, o reconhecimento global dos riscos do meio ambiente e da necessidade de um esforço coletivo dos governos e dos setores produtivos para alteração do sistema produtivo em vigência (BHANDARI, 1998).

Em 1988 foi realizada a primeira conferência mundial sobre o clima, na cidade de Toronto, Canadá, inaugurando a discussão internacional à cerca da previsão e prevenção das 
mudanças climáticas de causas antrópicas que poderiam vir a comprometer o bem-estar da humanidade.

Nessa conferência houve a criação do IPCC (Painel Intergovernamental sobre Mudança do Clima) que teve e tem como principal objetivo a revisão da produção científica na área climática, bem como o fornecimento de subsídios as partes dos tratados internacionais que tratam sobre a problemática.

Importante ser ressaltado que o IPCC teve sua primeira contribuição expressiva no ano de 1990, quando da publicação de seu relatório sobre as mudanças climáticas, confirmando tal fenômeno, o que foi um passo significativo para a o convencimento das diversas nações globais sobre a delicada e importante questão do clima, facilitando a negociação de um tratado internacional sobre a problemática. A partir daí, criou-se um comitê intergovernamental de negociações com mandato para elaborar uma Convenção-Quadro da ONU sobre mudanças do clima.

Esse comitê concluiu seus trabalhos apresentando, em 1992, na sede da ONU, em Nova York, o texto final da Convenção do Clima, que foi levada para assinatura na Conferência das Nações Unidas para o Meio Ambiente, sediada no Brasil, na cidade do Rio de Janeiro, entrando em vigor em 21 de março de 1994.

Passados 20 anos da Declaração de Estocolmo houve a necessidade de uma nova reunião Internacional entre os Estados, não somente para se analisar a situação atual da proteção ambiental no mundo, mas também para observar quais as mudanças ocorridas nas últimas duas décadas.

Denominada de Conferência das Nações Unidas para o Meio Ambiente, o evento teve sede no Brasil, na cidade do Rio de Janeiro, em 1992 teve como principal mérito reunir tanto representantes de Estados, como de Organizações Internacionais e Organizações Não Governamentais. 
Para tratar sobre a temática do efeito estufa e suas repercussões mundiais foi estabelecida, durante essa conferência a Convenção Quadro das Nações Unidas sobre Mudanças Climáticas (em inglês, United Nations Framework Convention on Climate Change - UFCCC).

A convenção do clima teve como meta principal propor obrigações aos países signatários de realizarem esforços conjuntos e reconhecer o direito das partes ao desenvolvimento sustentável e a prioridade dos países não desenvolvidos erradicarem a pobreza e outras preocupações do século XIX que os países desenvolvidos já superaram há várias décadas (moradia adequada, saúde, alimentação e educação a população) (SABBAG, 2009).

Ou seja, o objetivo da Convenção foi estabilizar as concentrações dos gases de efeito estufa na atmosfera em nível seguro, garantindo a continuidade da produção de alimentos e permitindo a sustentabilidade do desenvolvimento econômico-social das Partes.

Outro ponto que deve ser cuidadosamente destacado é que a Convenção estabeleceu para países desenvolvidos o dever de iniciativa no combate as mudanças climáticas e seus efeitos, instituindo o retorno de suas emissões de gases de efeito estufa por volta do ano 2000 , aos níveis anteriores a 1990.

A Convenção apresenta alguns instrumentos que possibilitam o alcance de seu objetivo, bem como prevê diversas obrigações às partes. Cabe lembrar que o órgão máximo da Convenção é a Conferência das Partes (COP), criada em seu artigo $7^{\circ}$ com mandato para proferir decisões, em suas reuniões anuais, para a implementação da Convenção.

No ano de 1995, a primeira Conferência das Partes (COP 1) é realizada na cidade de Berlim, chegando-se a conclusão de que os países desenvolvidos não conseguiriam atingir os índices estabelecidos para o ano de 2000, sendo assinado, nessa Conferência, o mandato de Berlim, que estabelece entre outras metas, a revisão dos compromissos para o ano de 2000. Dentre esses compromissos destacam-se o estabelecimento, para países desenvolvidos, de metas quantitativas de redução de emissões de gases de efeito estufa para 2005, 2010 e 2020, bem como o dever de descreverem as políticas e medidas necessárias para alcançar as metas, com um 
prazo até a $3^{\text {a }}$ Conferência das Partes (COP 3), que seria realizada em 1997. Passado dois anos de intensas negociações foi assinado na $3^{a}$ Conferência das Partes (COP 3) o protocolo de Quioto, que entrou em vigência apenas em 2005, após a ratificação russa em novembro de 2004.

1.7 O protocolo de Quioto.

Esse protocolo compromete uma série de nações (Anexo I) da Convenção do Clima, em sua esmagadora maioria países industrializados, a reduzir suas emissões em média 5\% - em relação aos níveis de 1990 - para o período de 2008 a 2012 (Tabela 4).

Cabe ser ressaltado que os 5\% corresponde a uma média, sendo que os compromissos de emissão variam de 8\% abaixo a 10\% acima dos níveis de 1990. Enquanto o Japão e o Canadá devem reduzir suas emissões em 6\% do nível de 1990, a Islândia está autorizada a aumentar suas emissões em 10\%, o que influencia de forma brutal o comércio de emissões, já que os compradores mais ávidos de créditos de carbono provavelmente se encontrarão em países com metas elevadas de redução de emissão, gerando uma boa demanda no mercado de carbono (SABBAG, 2009). No entanto, argumenta-se que seria necessária uma redução de $60 \%$ das emissões para se alcançar um nível seguro de concentração de gases de efeito estufa na atmosfera (SABBAG, 2009).

O Protocolo só entrou em vigor em 2005, depois que a Rússia aceitou a ratificação, em novembro de 2004, uma vez que a validade do documento só se daria quando fosse ratificado por pelo menos 55 países e que representassem, no mínimo, 55\% das emissões feitas em 1990.

Cerca de 100 países já ratificaram o documento, mas os Estados Unidos, o maior emissor de gases poluentes do mundo $(36,1 \%)$, não assinaram, alegando que a redução poderia acarretar em recessão e que as teorias sobre aquecimento global são questionáveis. 
A Austrália, que relutou em assinar o protocolo, aderiu ao acordo em dezembro de 2007, durante a Conferência das Nações Unidas. Com a decisão australiana, os Estados Unidos ficam isolados em relação ao resto dos países desenvolvidos.

Para facilitar o cumprimento de parte das metas estabelecidas para as Partes do Anexo I, levando em consideração que o cumprimento dessas metas exigiria consideráveis esforços econômicos, o protocolo estabeleceu três mecanismos de flexibilização: a Implementação Conjunta (Joint Implemention), o Comércio de Emissões (Emission Trading) e o Mecanismo de Desenvolvimento Limpo-MDL (Clean Development Mechanism) (SABBAG, 2009).

Tabela 4: Países do Anexo B do Protocolo de Quioto.

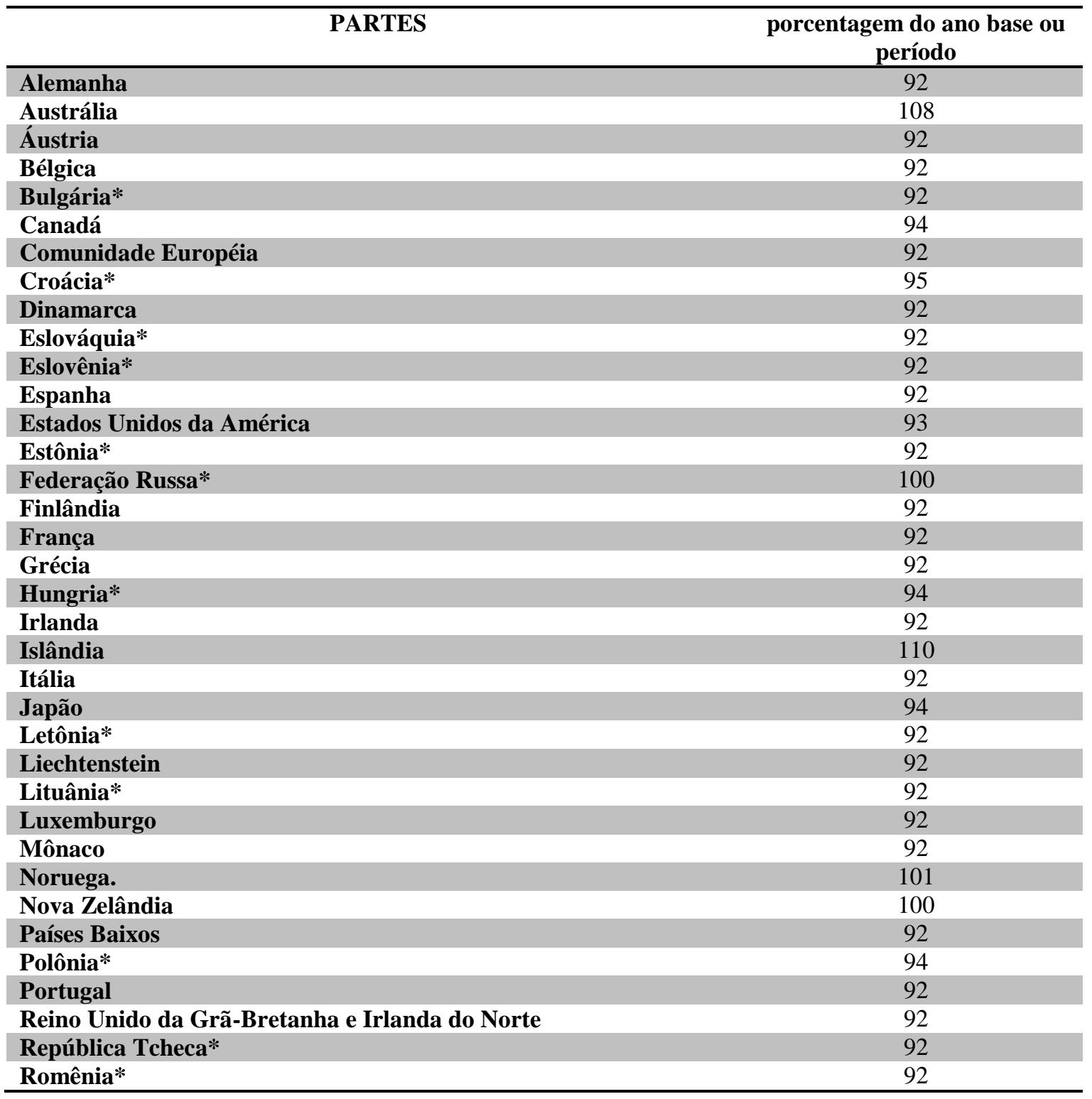




\begin{tabular}{lc}
\hline Suécia & 92 \\
Suíça & 92 \\
Ucrânia* & 100 \\
\hline
\end{tabular}

* Países em processo de transição para uma economia de mercado.

Fonte: Protocolo de Quioto 1997

A Implementação Conjunta, nos termos do artigo $6^{\circ}$ do Protocolo de Quioto, consiste numa atividade de projeto de redução de emissão de gases de efeito estufa que é implementada por duas Partes constantes do Anexo I, em outras palavras, é a iniciativa conjunta entre dois países desenvolvidos para conseguirem atingir suas metas estipuladas de forma mais favorável economicamente.

Artigo $6^{\circ}$

"A fim de cumprir os compromissos assumidos sob o Artigo 3, qualquer Parte incluída no Anexo I pode transferir para ou adquirir de qualquer outra dessas Partes unidades de redução de emissões resultantes de projetos visando a redução das emissões antrópicas por fontes ou o aumento das remoções antrópicas por sumidouros de gases de efeito estufa em qualquer setor da economia, desde que:

(a) O projeto tenha a aprovação das Partes envolvidas;

(b) O projeto promova uma redução das emissões por fontes ou um aumento das remoções por sumidouros que sejam adicionais aos que ocorreriam na sua ausência;

(c) A Parte não adquira nenhuma unidade de redução de emissões se não estiver em conformidade com suas obrigações assumidas sob os Artigos 5 e 7; e

(d) A aquisição de unidades de redução de emissões seja suplementar às ações domésticas realizadas com o fim de cumprir os compromissos previstos no Artigo 3.

2. A Conferência das Partes na qualidade de reunião das Partes deste Protocolo pode, em sua primeira sessão ou assim que seja viável a partir de então, aprimorar diretrizes 
para a implementação deste Artigo, incluindo para verificação e elaboração de relatórios.

3. Uma Parte incluída no Anexo I pode autorizar entidades jurídicas a participarem, sob sua responsabilidade, de ações que promovam a geração, a transferência ou a aquisição, sob este Artigo, de unidades de redução de emissões.

4. Se uma questão de implementação por uma Parte incluída no Anexo I das exigências mencionadas neste parágrafo é identificada de acordo com as disposições pertinentes do Artigo 8, as transferências e aquisições de unidades de redução de emissões podem continuar a ser feitas depois de ter sido identificada a questão, desde que quaisquer dessas unidades não sejam usadas pela Parte para atender os seus compromissos assumidos sob o Artigo 3 até que seja resolvida qualquer questão de cumprimento." (PROTOCOLO DE QUIOTO, 2005).

Já o Comércio de Emissões criado pelo artigo 17 do Protocolo de Quioto, permite que as Partes do anexo I, negociem entre si parte de suas permissões de emissão, como forma de conseguirem atingir suas metas. Importante destacar, que ao contrário da Implementação Conjunta, o Comércio de Emissões não prevê a utilização de atividades de projetos. Dessa forma um país que não tivesse atingido sua meta de redução poderia comprar uma quota de emissão de outro país que a superou (SABBAG, 2009).

Artigo 17. "A Conferência das Partes deve definir os princípios, as modalidades, regras e diretrizes apropriados, em particular para verificação, elaboração de relatórios e prestação de contas do comércio de emissões. As Partes incluídas no Anexo B podem participar do comércio de emissões com o objetivo de cumprir os compromissos assumidos sob o Artigo 3. Tal comércio deve ser suplementar às ações domésticas com vistas a atender os compromissos quantificados de limitação e redução de emissões, assumidos sob esse Artigo." (PROTOCOLO DE QUIOTO, 2005). 
O MDL, criado pelo artigo $12^{\circ}$ do Protocolo de Quioto, é o único mecanismo de flexibilização que envolve a possibilidade de participação de países em desenvolvimento no mercado primário de carbono no âmbito do Protocolo de Quioto.

Artigo 12

1. Fica definido um mecanismo de desenvolvimento limpo.

2. O objetivo do mecanismo de desenvolvimento limpo deve ser assistir às Partes não incluídas no Anexo I para que atinjam o desenvolvimento sustentável e contribuam para o objetivo final da Convenção, e assistir às Partes incluídas no Anexo I para que cumpram seus compromissos quantificados de limitação e redução de emissões, assumidos no Artigo 3.

3. Sob o mecanismo de desenvolvimento limpo:

(a) As Partes não incluídas no Anexo I beneficiar-se-ão de atividades de projetos que resultem em reduções certificadas de emissões; $e$

(b) As Partes incluídas no Anexo I podem utilizar as reduções certificadas de emissões, resultantes de tais atividades de projetos, para contribuir com o cumprimento de parte de seus compromissos quantificados de limitação e redução de emissões, assumidos no Artigo 3, como determinado pela Conferência das Partes na qualidade de reunião das Partes deste Protocolo.

4. O mecanismo de desenvolvimento limpo deve sujeitar-se à autoridade e orientação da Conferência das Partes na qualidade de reunião das Partes deste Protocolo e à supervisão de um conselho executivo do mecanismo de desenvolvimento limpo. 
5. As reduções de emissões resultantes de cada atividade de projeto devem ser certificadas por entidades operacionais a serem designadas pela Conferência das Partes na qualidade de reunião das Partes deste Protocolo, com base em:

(a) Participação voluntária aprovada por cada Parte envolvida;

(b) Benefícios reais, mensuráveis e de longo prazo relacionados com a mitigação da mudança do clima, $e$

(c) Reduções de emissões que sejam adicionais as que ocorreriam na ausência da atividade certificada de projeto.

6. O mecanismo de desenvolvimento limpo deve prestar assistência quanto à obtenção de fundos para atividades certificadas de projetos quando necessário.

7. A Conferência das Partes na qualidade de reunião das Partes deste Protocolo deve, em sua primeira sessão, elaborar modalidades e procedimentos com o objetivo de assegurar transparência, eficiência e prestação de contas das atividades de projetos por meio de auditorias e verificações independentes.

8. A Conferência das Partes na qualidade de reunião das Partes deste Protocolo deve assegurar que uma fração dos fundos advindos de atividades de projetos certificadas seja utilizada para cobrir despesas administrativas, assim como assistir às Partes países em desenvolvimento que sejam particularmente vulneráveis aos efeitos adversos da mudança do clima para fazer face aos custos de adaptação.

9. A participação no mecanismo de desenvolvimento limpo, incluindo nas atividades mencionadas no parágrafo 3(a) acima e na aquisição de reduções certificadas de emissão, pode envolver entidades privadas elou públicas e deve sujeitar-se a qualquer orientação que possa ser dada pelo conselho executivo do mecanismo de desenvolvimento limpo. 
10. Reduções certificadas de emissões obtidas durante o período do ano 2000 até o início do primeiro período de compromisso podem ser utilizadas para auxiliar no cumprimento das responsabilidades relativas ao primeiro periodo de compromisso" (PROTOCOLO DE QUIOTO, 2005).

Por meio desse mecanismo são implantadas atividades de projetos de redução de emissão ou redução de gases de efeito estufa, gerando, proporcionalmente, créditos de carbonos, os quais podem ser utilizados por países desenvolvidos ou economias em transição no cumprimento de suas metas definidas no art. $3^{\circ}$ e anexo B do Protocolo de Quioto.

Jacoby, Schmalensee e Wing (1999) identificaram cinco aspectos-chave da arquitetura do Protocolo de Quioto: (JACOBY, SCHMALENSE \& WING, 1999 apud ANDRADE \& COSTA 2008)

“(i) Negociações de limites de emissões visando ao curto prazo.

(ii) Novos comprometimentos baseados em dados recentes.

(iii) Provisão para o Comércio de Emissõe.

(iv) Estabilização atmosférica como objetivo central.

(v) Alocação de ônus influenciada pela capacidade de pagamento.”

(i) Negociações de limites de emissões visando ao curto prazo - As metas de emissões foram projetadas para serem cumpridas em um período de comprometimento (20082012). Na impossibilidade de cumprimento dessas metas, ou até mesmo de revisão dos compromissos, serão estabelecidas negociações rotativas. Ainda importante ressaltar que o protocolo de Quioto prevê outros períodos de redução de emissões e aponta que as negociações 
para um segundo período de negociação deverão começar com antecedência mínima de sete anos do primeiro período.

(ii) Novos comprometimentos baseados em dados recentes. - Duas são as exceções para que os compromissos de redução de emissões não sejam estabelecidos o ano base de 1990 . Primeira: as antigas nações socialistas que passam por uma transição para economia de mercado poderão optar por outro ano como ano base. Segunda: para contabilização das emissões de HFCs, PFCs e $\mathrm{SF}_{6}$, as partes podem escolher como ano base 1990 ou 1995.

(iii) Provisão para o Comércio de Emissões. - Para que haja uma estabilização das emissões dos gases de efeito estufa é necessário uma implementação de um comércio de emissões que seria o grande estímulo para a redução pois passaria a haver uma moeda de troca entre as nações.

(iv) Estabilização atmosférica como objetivo central. - O foco central da Convenção Climática é a estabilização das concentrações atmosféricas de gases de efeito estufa. As discussões estão focadas no intervalo entre 450 e 650 ppm.

(v) Alocação de ônus influenciada pela capacidade de pagamento.

A CQNUMC divide os países em três categorias e um agregado:

- Anexo II: grupo que inclui as nações ricas. Assemelha-se ao conjunto de países membros da OCDE, em 1990;

- Economias em Transição: o grupo abrange os países da Europa Oriental e a maioria dos países da antiga União Soviética, que têm rendas muito mais baixas que a maioria dos países da OCDE;

- Anexo I: esse agregado é a combinação do Anexo II e das Economias em Transição; 
- Não-Anexo I: o mundo em desenvolvimento, alguns com renda per capita similar aos países menos bem sucedidos das Economias em Transição, porém, a maioria é muito mais pobre.

Complementarmente, uma divisão é feita dentro do próprio Anexo I: às Economias em Transição foram dados certos graus de flexibilidade, presumivelmente para levar em consideração seu baixo status econômico dentro do grupo do Anexo I.

As diferenças de renda também perpassam outras partes da operacionalização do Protocolo, como a assistência aos países em desenvolvimento, que, em tese, inclui assistência na obtenção e análise de dados, ajuda financeira aos países mais vulneráveis às mudanças climáticas e transferência de tecnologia.

Dessa forma, o protocolo estabelece uma série de iniciativas que devem ser observadas para a redução das emissões de gases de efeito estufa. O Quadro 1 traz de forma resumida as principais medidas para atender as reduções das emissões.

Quadro 1: Iniciativas para atendimento das reduções de emissões de gases de efeito estufa prevista no Protocolo de Quioto.

- Aumento da eficiência energética em setores relevantes da economia;

- Proteção e aumento de sumidouros e reservatórios de gases de efeito estufa sobre o meio ambiente como as florestas;

- Promoção de práticas sustentáveis de manejo florestal, florestamento e reflorestamento;

- Promoção de formas sustentáveis de agricultura;

- Pesquisa, promoção, desenvolvimento e aumento do uso de formas novas e renováveis de energia;

- Promoção e pesquisa de tecnologias de seqüestro de dióxido de carbono;

- Promoção e pesquisa de tecnologias ambientalmente seguras, que sejam avançadas e inovadoras;

- Redução gradual ou eliminação de incentivos fiscais, de isenções tributárias e tarifárias e 
de subsídios para todos os setores emissores de gases de efeito estufa que sejam contrários ao objetivo do protocolo;

- Convenção e aplicação de instrumentos de mercado que reduzam as emissões de gases poluentes;

- Estímulo a reformas adequadas em setores relevantes, visando a promoção de políticas e medidas que limitem ou reduzam emissões de gases de efeito estufa;

- Limitação e/ou redução de emissões de metano por meio de sua recuperação e utilização no tratamento de resíduos, bem como na produção, no transporte e na distribuição de energia;

- Cooperação, compartilhamento de informações sobre novas tecnologias adotadas.

Fonte: http://www.uol.br

$1.8 \mathrm{O}$ acordo de Marrakesh

O Acordo de Marrakesh define as regras operacionais para LULUCF (Land Use, Land Use Change and Forestry), para os mecanismos de flexibilização e para os Artigos 5, 7 e 8, que tratam, respectivamente, da definição do sistema nacional para o inventário de emissões, das informações adicionais à Convenção derivadas do Protocolo e do processo de revisão das comunicações nacionais (SABBAG, 2009).

Regras de limitação com relação à utilização de créditos oriundos de florestas e agricultura foram estabelecidas, incluindo, ainda, a instituição de uma nova unidade de medição (RMU - Removal Unit) que não poderá ser transferida para períodos de cumprimento futuros (banking). A transferência de outras unidades (AAU/CER/ERU) para períodos futuros de compromissos será permitida, porém créditos gerados por MDL e JI terão limites máximos para transferência. A transferência de AAU/CER/ERU/RMU entre as Partes do ANEXO I será irrestrita (SABBAG, 2009). 
Fundos internacionais foram estabelecidos para auxiliar os países menos desenvolvidos se adaptar aos efeitos das mudanças climáticas, entre eles o Fundo de Adaptação que será mantido com uma taxa de $2 \%$ sobre os projetos de MDL.

Em se tratando de mecanismo de desenvolvimento limpo a principal decisão tomada foi a decisão 17/CP.7, chamada de "Modalidades e Procedimentos do Mecanismo de Desenvolvimento Limpo", posteriormente ratificada na COP/MOP1(Decisão 3/CMP.1).

Sem sombra de dúvida essa decisão dá encerramento a um extenso período de negociações inaugurando uma evolução no que tange ao mercado de carbono, garantindo aos investidores maior segurança jurídica ao estabelecer regras procedimentais claras sobre a geração e titularidade de créditos de carbono (SABBAG, 2009).

Essa decisão confere amplos poderes para que os países em desenvolvimento que hospedem projetos de MDL, aprovem seus projetos pelo instrumento conhecido como Carta de Aprovação, reconhecendo, por conseguinte, que o projeto será indispensável para o desenvolvimento sustentável do Estado e que será implantado voluntariamente.

Ainda, tal decisão enfatiza que as atividades de projeto do mecanismo de desenvolvimento limpo devem conduzir à transferência de tecnologia e know-how ambientalmente seguros e saudáveis, além do exigido no âmbito do Artigo 4, parágrafo 5, da Convenção e do Artigo 10 do Protocolo de Quioto.

Regulamentou, ainda, a criação do Comitê Executivo do MDL. Este Conselho será licenciado a estar autorizando a aprovação de metodologias de linhas de base, planos de monitoramento e limites para projetos, acreditando entidades operacionais, desenvolvendo e mantendo registros dos projetos de MDL.

Necessário se ressaltar que a Decisão 15/CP.7, retificada pela Decisão 2/CMP.1 que definiu os princípios, natureza e instrumentalidade dos mecanismos criados pelo Protocolo de Quioto. 
Os dois mais importantes pontos do acordo foram a definição dos requisitos de participação em atividades de MDL, nos artigos 28 a 34 do Anexo da Decisão 17/CP.7 e os procedimentos para a autorização do ciclo de projeto do MDL (SABAGG, 2009).

Esses acordos reforçaram os princípios e objetivos do Protocolo para regulamentar, de maneira pormenorizada, as atividades de projeto de MDL (SABAGG, 2009). 


\section{CAPÍTULO II - O MECANISMO DE DESENVOLVIMENTO LIMPO}

\subsection{Conceito de Mecanismo de Desenvolvimento Limpo (MDL)}

Com o Protocolo de Quioto criou-se a possibilidade para que o mercado possa auxiliar no processo de redução das emissões de Gases de efeito estufa, por meio de criação de um valor comercializável para essas reduções, semelhante aos mecanismos existentes para alguns gases poluidores na Europa e Estados Unidos (ROCHA, 2003).

Sob essa ótica, foram estabelecidos mecanismos de flexibilização, entre eles o CDM Clean Development Mechanism que em português recebeu a seguinte versão: mecanismo de desenvolvimento limpo (MDL - Artigo 12 do Protocolo de Quioto).

A ideia central do MDL consiste em que cada tonelada de $\mathrm{CO}_{2}$ deixada de ser emitida ou retirada da atmosfera por um país em desenvolvimento poderá ser negociada no mercado mundial, criando um novo meio para redução das emissões globais. Os países do ANEXO I do Protocolo de Quioto estabelecerão em seus territórios metas para redução de $\mathrm{CO}_{2}$ junto aos principais emissores.

As empresas alocadas nesses países que não conseguirem ou não forem adeptas a tais reduções de emissões poderão adquirir os Certificados de Emissões Reduzidas (CER) em países em desenvolvimento e utilizar tais certificações para cumprimento de suas respectivas metas.

Já os países em desenvolvimento deverão utilizar o MDL para promover seu desenvolvimento sustentável. Dessa forma, os projetos de MDL forma divididos da seguinte forma:

- Fontes renováveis e alternativas de energia;

- Eficiência / conservação de energia; e,

- Reflorestamento e estabelecimento de novas florestas 
Um projeto de MDL, tendo cumprido todo seu processo, gera um título comercializável em mercado de valores denominado de Reduções Certificadas de Emissão. Irá se trabalhar nesse capítulo com alguns elementos desses projetos, para que possa ser realizada uma abordagem crítica de seus elementos. As demais fases procedimentais acerca da geração de RCEs estão presentes no Anexo desse trabalho.

Os elementos essenciais para que um projeto de MDL se torne efetivo é que o mesmo contemple os critérios de elegibilidade, sustentabilidade e o ciclo do projeto de MDL.

O critério de elegibilidade se traduz nos seguintes elementos:

a) Voluntariedade - Respeitando-se a soberania do Estado não deverá haver imposição internacional alguma a eleição do projeto, devendo o país designar uma autoridade nacional, que no caso brasileiro, é o Ministério da Ciência e Tecnologia.

b) Benefícios reais, mensuráveis e de longo prazo relacionados com a mitigação da mudança do clima - só serão consideradas as reduções se atenderem os critérios de adicionalidade e estiverem abaixo do nível de emissão calculado como a linha base.

c) Adicionalidade - um projeto de MDL será adicional quando sua implementação reduzir as emissões de GEE por certa fonte de emissão inferior a linha de base (estimativa da quantidade de gases de efeito estufa GEE emitida por atividades econômicas e da sociedade, ou seja, é a referência para calcular a redução das emissões de GEE quando implantado um projeto de MDL).

O segundo critério de análise é o da sustentabilidade. Esse critério deve observar os cincos aspectos elencados pela própria autoridade brasileira designada, qual seja sustentabilidade ambiental local, o desenvolvimento das condições de trabalho e a geração líquida de empregos, a distribuição de renda, capacitação e desenvolvimento tecnológico, bem como a integração regional e a articulação com outros setores. 
Ressalte-se que não há da obrigatoriedade do projeto de MDL contemplar todos os cinco parâmetros acima indicados, pois isso variará conforme o escopo de cada atividade de projeto proposta no âmbito do MDL.

O último elemento essencial para o cumprimento do projeto de MDL é o ciclo do projeto. Esse elemento trata das questões técnicas para obtenção das RCEs. Nessa etapa irá se demonstrar os requisitos do documento de concepção do projeto que se aprovado, gera RCEs (para obtenção mais detalhadas sobre o procedimento de obtenção de RCEs vide Anexo I dessa pesquisa).

a) Documento de concepção do projeto - Deverá conter metodologia para estimativa da linha de base e monitoramento antecipadamente aceitos pelo Conselho Executivo do MDL, opção de escolha da duração do projeto (máximo de sete anos, com possibilidade de duas renovações por igual prazo, ou o máximo de dez anos, sem possibilidade de renovação, salvo períodos específicos em projetos florestais), cálculo estimativo da quantidade/volume de gases de efeito estufa emitidos pela fonte e cálculo estimativo das futuras emissões permitindo demonstrar as adicionalidades e plano de monitoramento das reduções de emissão de gases efeito estufa ou de ou absorção de gás carbônico em decorrência da atividade de projeto.

Dessa forma, atendendo aos critérios e procedimentos anteriores se tem a aprovação de um projeto de MDL.

2.2 Dados preliminares de MDL no Brasil e no Mundo

Conforme destacado anteriormente, uma atividade de projeto entra no sistema do MDL quando há validação por uma Entidade Operacional Designada (EOD).

Um total de 5897 projetos, no mundo, encontrava-se em alguma fase do ciclo de projetos do MDL, sendo 2.067 já registrados pelo Conselho Executivo do MDL e $3.830 \mathrm{em}$ 
outras fases do ciclo (MCT, 2011) (Figura 5). As Figuras 6 e 7 mostram o status atual das atividades de projeto em estágio de validação, aprovação e registro.

O Brasil ocupa o $3^{\circ}$ lugar em número de atividades de projeto, com 440 projetos (7\%), sendo que em primeiro lugar encontra-se a China com 2197 (37\%) e, em segundo, a Índia com 1575 projetos (27\%), (MCT, 2011) (Figura 5).

Sendo responsável pela redução de $378.905 .623 \mathrm{tCO}_{2}$, o que corresponde a $6 \%$ do total mundial para o primeiro período de obtenção de créditos, o Brasil ocupa a terceira posição no tocante às reduções de emissões associadas aos projetos no ciclo do MDL, que podem ser de no máximo 10 anos para projetos de período fixo ou de 7 anos para projetos de período renovável (os projetos são renováveis por no máximo três períodos de 7 anos dando um total de 21 anos) (MCT, 2011).

A China ocupa o primeiro lugar com 3.176.106.595 $\mathrm{tCO}_{2}$ e a serem reduzidas (47\%), seguida pela Índia com 1.549.754.994 de $\mathrm{tCO}_{2} \mathrm{e}(23 \%)$ de emissões projetadas para o primeiro período de obtenção de créditos (MCT, 2011).

Figura 5: Número de atividades de projeto no âmbito do MDL no mundo

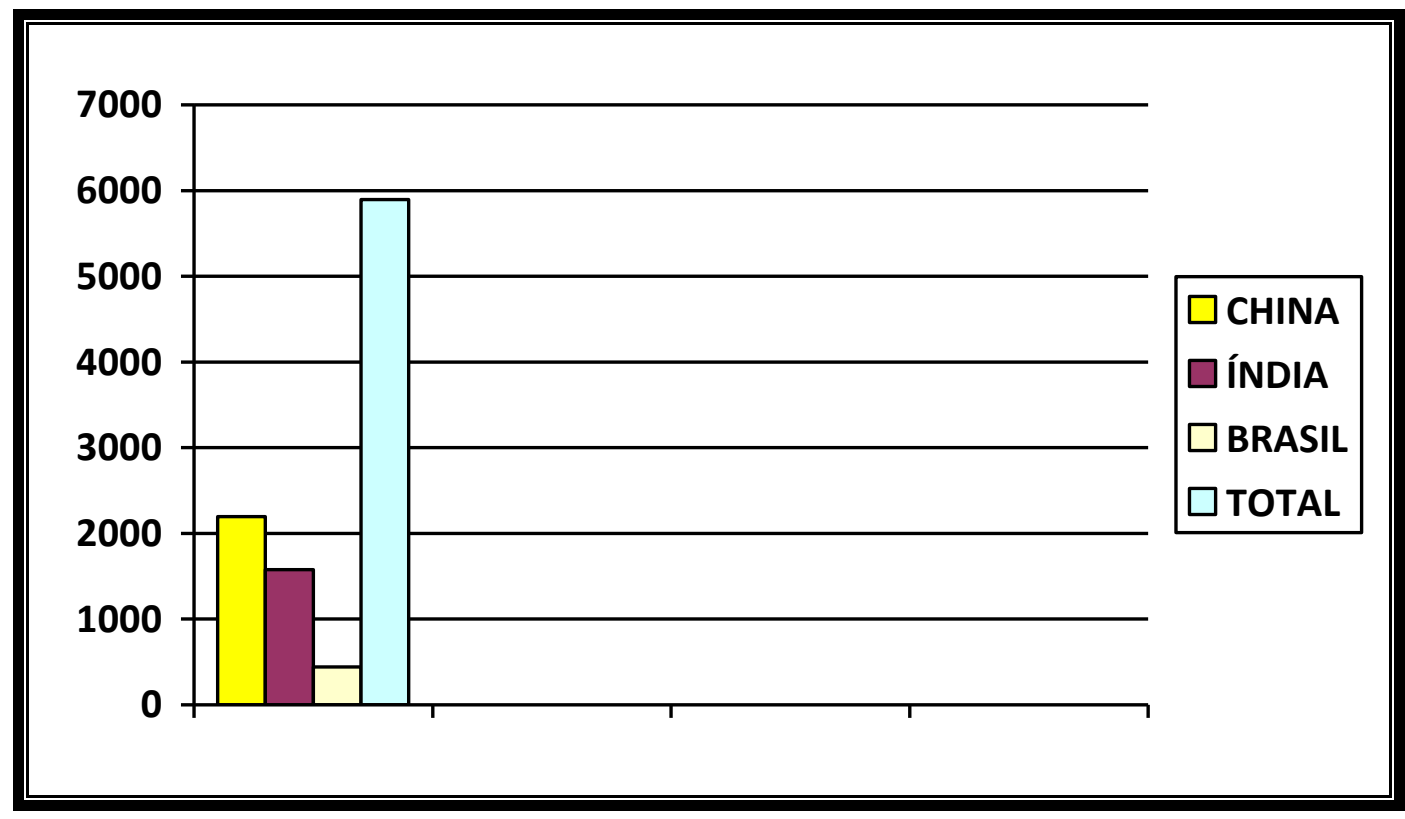

Fonte: Ministério da Ciência e Tecnologia, 2011 
Figura 6: Participação no total de atividades de projeto no âmbito do MDL no mundo

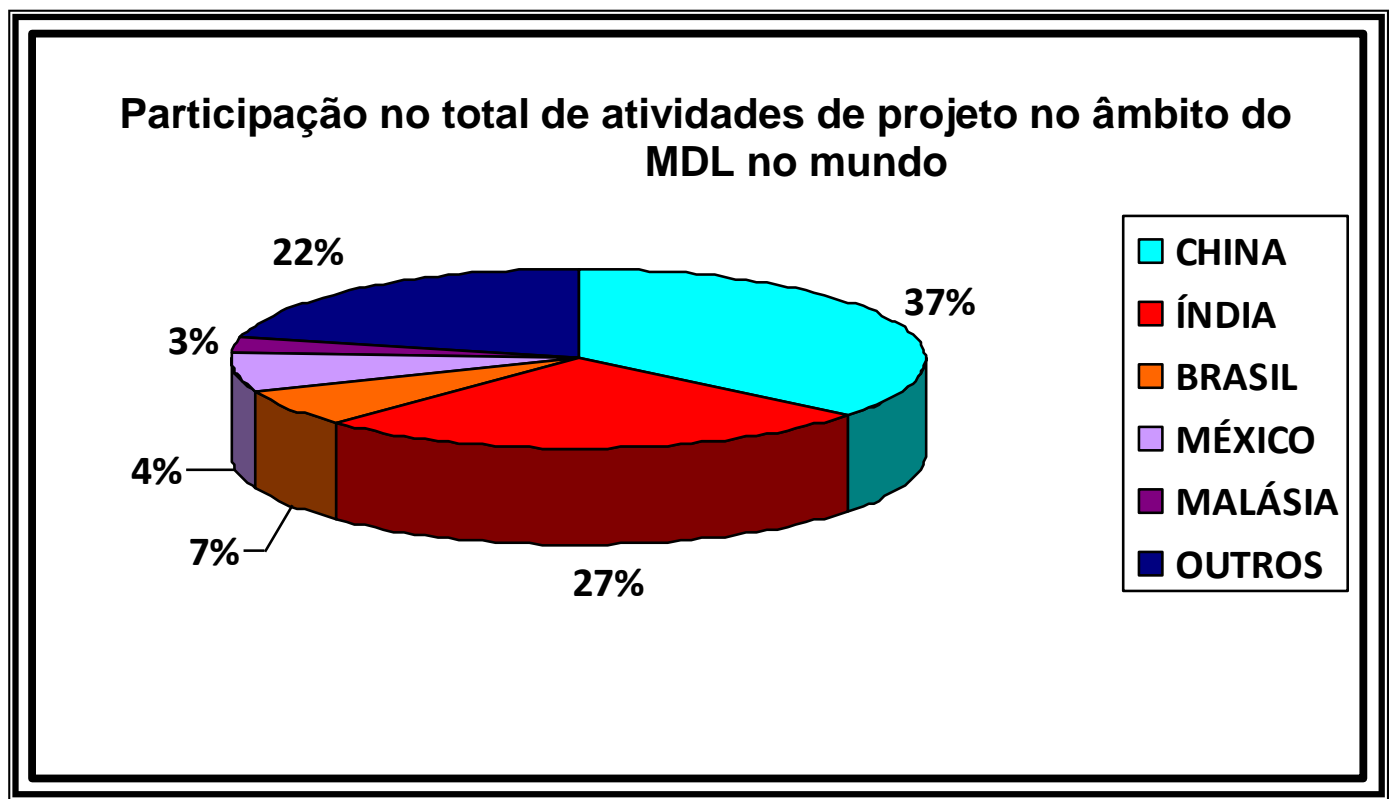

Fonte: Ministério da Ciência e Tecnologia, 2011

Figura 7: Participação no Potencial de Redução de emissões para o primeiro período de obtenção de créditos

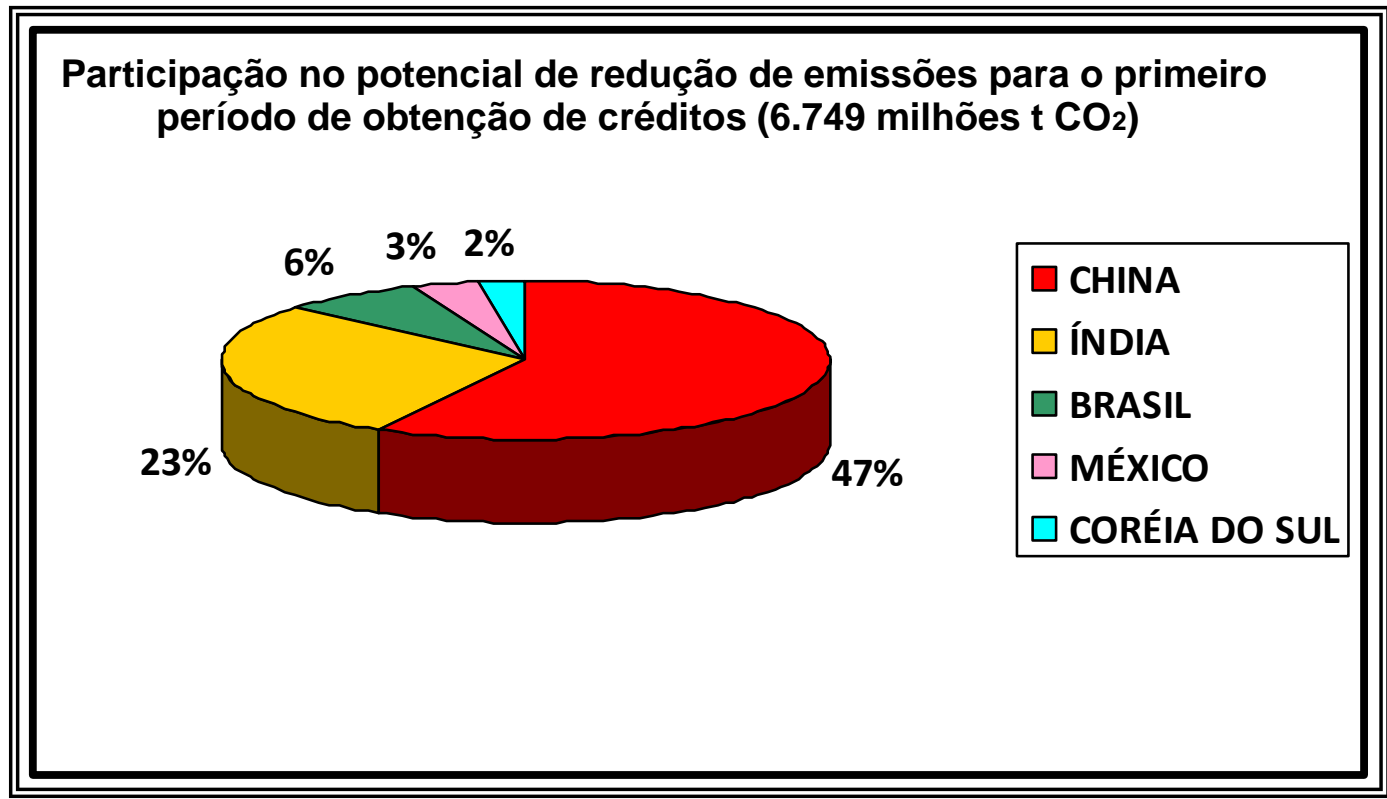

Fonte: Ministério da Ciência e Tecnologia, 2011 
Com relação aos escopos setoriais que mais têm atraído o interesse dos participantes de projetos no Brasil há uma nítida predominância das atividades de projeto está no setor energético (MCT, 2011) (Figura 8).

Figura 8: Distribuição das atividades de projeto no Brasil por escopo setorial

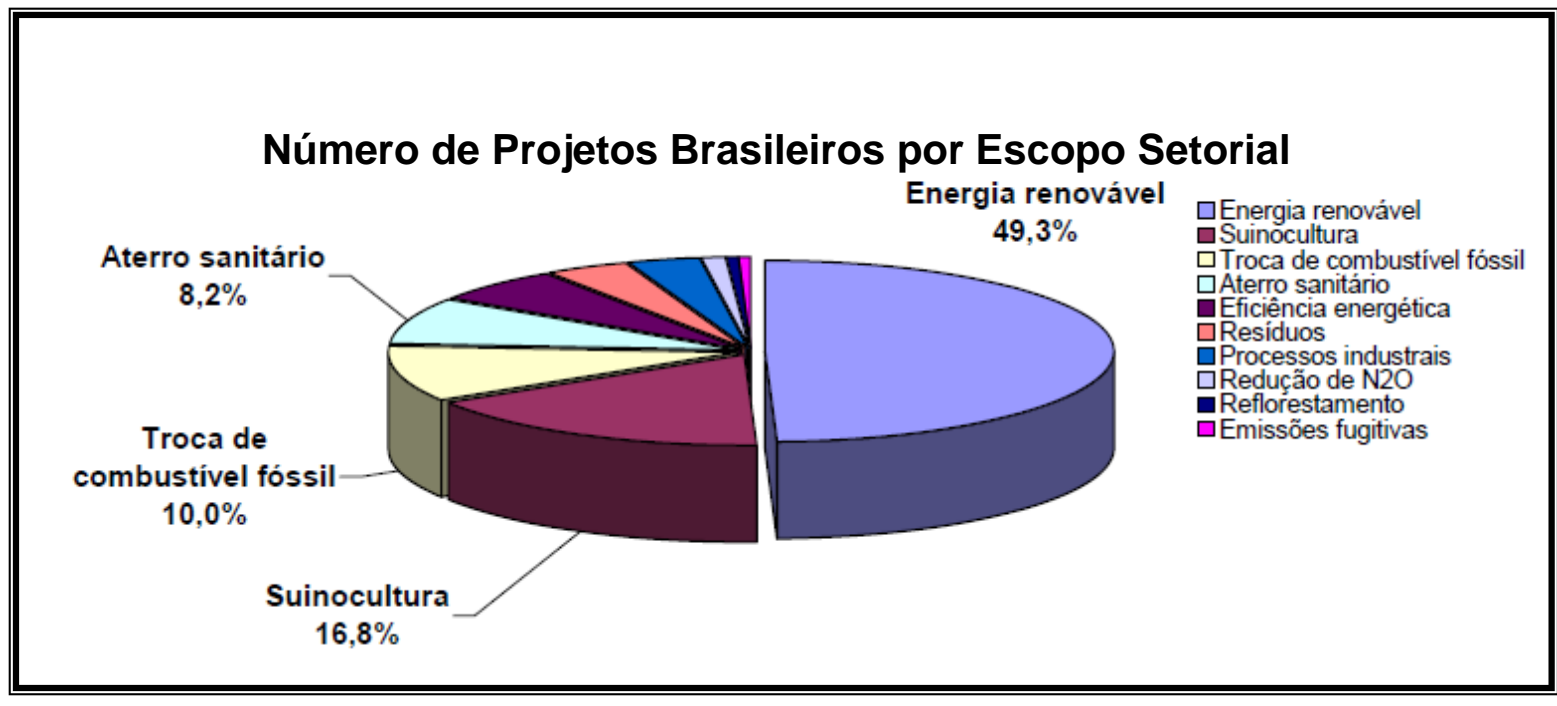

Fonte: Ministério da Ciência e Tecnologia, 2011

A tabela 5 mostra que o maior número de projetos brasileiros é desenvolvido na área de geração de energia e suinocultura, os quais representam a maioria das atividades de projeto (66\% somados) (MCT, 2011).

Tabela 5: Distribuição das atividades de projeto no Brasil por tipo de projeto

\begin{tabular}{|c|c|c|c|c|c|c|}
\hline $\begin{array}{c}\text { Projetos em } \\
\text { Validação/Aprovação }\end{array}$ & $\begin{array}{c}\text { Número } \\
\text { de } \\
\text { projetos }\end{array}$ & $\begin{array}{c}\text { Redução } \\
\text { anual de } \\
\text { emissão }\end{array}$ & $\begin{array}{c}\text { Redução de } \\
\text { emissão no } \\
1^{\circ} \text { período } \\
\text { de obtenção } \\
\text { de crédito }\end{array}$ & $\begin{array}{c}\text { Número } \\
\text { de } \\
\text { projetos }\end{array}$ & $\begin{array}{c}\text { Redução } \\
\text { anual de } \\
\text { emissão }\end{array}$ & $\begin{array}{c}\text { Redução de } \\
\text { emissão no } \\
1^{0} \text { período } \\
\text { de obtenção } \\
\text { de crédito }\end{array}$ \\
\hline Energia renovável & 217 & 18.556 .339 & 136.175 .839 & $49,3 \%$ & $38,6 \%$ & $35,9 \%$ \\
\hline Aterro Sanitário & 36 & 11.327 .606 & 84.210 .095 & $8,2 \%$ & $23,6 \%$ & $22,2 \%$ \\
\hline Redução de $\mathrm{N}_{2} \mathrm{O}$ & 5 & 6.373 .896 & 44.617 .272 & $1,1 \%$ & $13,3 \%$ & $11,8 \%$ \\
\hline Suinocultura & 74 & 4.140 .069 & 38.617 .535 & $16,8 \%$ & $8,6 \%$ & $10,2 \%$ \\
\hline $\begin{array}{l}\text { Troca de combustível } \\
\text { fóssil }\end{array}$ & 44 & 3.271 .516 & 27.382 .490 & $10,0 \%$ & $6,8 \%$ & $7,2 \%$ \\
\hline Eficiência Energética & 28 & 2.027 .173 & 19.853 .258 & $6,4 \%$ & $4,2 \%$ & $5,2 \%$ \\
\hline Reflorestamento & 2 & 434.438 & 13.033 .140 & $0,5 \%$ & $0,9 \%$ & $3,4 \%$ \\
\hline Processos industriais & 14 & 1.002 .940 & 7.449 .083 & $3,2 \%$ & $2,1 \%$ & $2,0 \%$ \\
\hline Resíduos & 17 & 646.833 & 5.002 .110 & $3,9 \%$ & $1,3 \%$ & $1,3 \%$ \\
\hline Emissões fugitivas & 3 & 269.181 & 2.564 .802 & $0,7 \%$ & $0,6 \%$ & $0,7 \%$ \\
\hline
\end{tabular}

Fonte: Ministério da Ciência e Tecnologia, 2011 
Os escopos que mais reduzirão emissões de $\mathrm{CO}_{2}$ são os de energia renovável, aterro sanitário e redução de $\mathrm{N}_{2} \mathrm{O}$, totalizando $70 \%$ do total de emissões de $\mathrm{CO}_{2}$ e a serem reduzidas no primeiro período de obtenção de créditos. Esses três setores apresentam um potencial de redução de emissões de 265.003.206 $\mathrm{tCO}_{2}$ e durante o primeiro período de obtenção de créditos (MCT, 2011).

\subsection{Análise crítica ao MDL no Brasil}

Apesar da apresentação do texto ser algo simplicista o mecanismo de MDL possui algumas complexidades e fatores que devem ser analisados com maior atenção.

Primeiramente, sem dúvida, o MDL é um processo que visa a sustentabilidade ambiental e que compactua com os preceitos de desenvolvimento sustentável discutidos nas inúmeras conferências sobre meio ambiente, promovidas em âmbito internacional.

$\mathrm{O}$ aspecto análise mais crítico começa pelo critério de elegibilidade. Na tabela 5 observa-se que os projetos de MDL no Brasil se concentram na área de energia renovável seguida das áreas de aterro sanitário, redução de $\mathrm{N}_{2} \mathrm{O}$, suinocultura e troca de combustíveis fósseis.

É extremamente importante compreender a realidade dos números apresentados. Elegibilidade das partes significa dizer que os Estados Nacionais não podem impor a outro a implementação de um projeto de MDL, ou de certa atividade inerente ao mesmo, independentemente de seu grau de desenvolvimento econômico. Entretanto, o que se vê é que existem esforços no sentido de aceitarem projetos que contemplem determinados setores em detrimento de outros.

Assim, os projetos de MDL no âmbito do protocolo de Quioto contemplam grandes projetos estruturais, havendo, por conseguinte, uma concentração muito grande de renda e 
capital nas mãos de grandes corporações envolvidas nos mesmos, em detrimento da pulverização de outras de ações que poderiam ser eleitas no âmbito do MDL e que praticariam efetivamente os preceitos contidos no critério de sustentabilidade que passa pelo desenvolvimento ambiental local, o desenvolvimento das condições de trabalho e a geração líquida de empregos, a distribuição de renda, dentre outros.

Evidentemente que países como a China, que possuem uma matriz energética baseada em carvão mineral, obtém maior vantagem na confecção de projetos de MDL, principalmente na substituição dessa matriz, algo que não acontece no Brasil, por predomínio de hidroeletricidade na matriz energética. Entretanto, o que se vê é que, muitas vezes, o governo brasileiro, principalmente na última década, vem apresentando um retrocesso ambiental no que tange a matriz energética diminuindo a hidroeletricidade em detrimento do aumento das termelétricas a base de carvão mineral.

Ou seja, enquanto se tem esforços no mundo, como o caso chinês, que concentra suas energias na mudança da matriz energética, principalmente para energia renováveis como a solar e eólica, no Brasil, o que se observa é um retrocesso na utilização das matrizes energéticas.

Exemplo emblemático é a "substituição" de coque de carvão por eucalipto na fabricação de ferro gusa no Brasil. Muitas corporações vendem esta alternativa como sustentável, uma vez que reduziria a exploração do carvão fóssil e seria renovável. Entretanto, o que se verifica de fato, é a manutenção da obsolescência do parque industrial siderúrgico que é altamente impactante nos recursos naturais.

Os projetos de energia renovável foram os mais expressivos no mundo em 2011, gerando $45 \%$ de todos os créditos comercializados. O setor eólico aparece como o grande dominante, respondendo por $30 \%$ do total do mercado, conforme demonstra o relatório State of the Voluntary Carbon Markets 2012. O relatório também registra o aumento da participação de projetos de Redução de Emissões por Desmatamento e Degradação (REDD), alcançando 9\%. 
É necessário se frisar que há, nos últimos anos, um aumento expressivo da participação de projetos por reflorestamento. Tal dado se mostra preocupante, uma vez que tais projetos dificilmente contribuem de forma efetiva, para o desenvolvimento sustentável local e para a adicionalidade.

Cabe ressaltar que um projeto é considerado "adicional" quando traz benefícios que não ocorreriam se o mesmo não existisse. Ou seja, no caso de reflorestamentos já ocorridos, o projeto não apresenta a adicionalidade, pois o reflorestamento já existia na ausência do projeto.

Outra crítica a ser realizada sobre o MDL passa pela estrutura procedimental do próprio mecanismo. É inevitável não ressaltar a burocracia do mecanismo de obtenção de RCEs. Mas além do problema burocrático procedimental a estrutura para obtenção da aprovação do MDL também demonstra falhas técnicas.

Como se sabe a competência para julgamento do MDL, no Brasil, pertence ao MCT que corresponde à autoridade designada. A crítica que se faz, concentra-se não na análise do procedimento em si, mas no descaso do cumprimento de alguns requisitos das partes envolvidas.

$\mathrm{Na}$ realidade um projeto de MDL para receber a aprovação deve contemplar os requisitos de elegibilidade, sustentabilidade e ciclo do projeto. Pois bem, a crítica em questão, está no fato da entidade designada ser órgão político que detém comissão técnica indicada para exercer cargos de confiança, e que não contempla a discussão entre as diferentes partes envolvidas no processo.

Dessa maneira, em muitas ocasiões, por se tratar de um órgão político, existem apreciações aceleradas sobre alguns projetos, encurtando o diálogo das partes envolvidas e atendendo a anseios de grupos corporativos específicos em detrimento de outros setores envolvidos. 
Outra indagação que se faz ao MDL é que este não contempla os agentes que são responsáveis pela manutenção durante décadas, quiçá séculos, dos recursos naturais como as comunidades indígenas, ribeirinhas e outros povos que sempre preservaram em sua forma de viver a manutenção desses recursos em detrimento do sistema corporativo que padece de crises e cria a necessidade da instauração de uma nova commodity para se reinventar. Trata-se do mecanismo de apropriação típico do sistema capitalista que tenta se modificar para atender aos anseios do próprio capital.

Por fim, devido à realidade brasileira procedimental ser altamente burocratizada, há uma crítica muito constante e de fácil constatação, qual seja o encarecimento dos custos processuais ou transacionais. 


\section{CAPÍTULO III - ESTUDO DE CASO: ANÁLISE DE PROJETOS DE MDL EM ATERRO SANITÁRIO E EM SILVICULTURA.}

3.1 Breve relato da política pública de resíduos sólidos no Brasil

Antes mesmo de realizar uma análise do caso concreto em questão, é necessário tecer alguns comentários sobre a questão das políticas públicas brasileiras, nas últimas décadas, em relação aos resíduos sólidos.

Não é de hoje a constatação de que a maioria dos municípios brasileiros dispõe seus resíduos sólidos domiciliares sem controle algum, ocasionando consequências como a contaminação do solo, das águas superficiais e dos respectivos lençóis freáticos, do ar, bem como a criação de focos de organismos patogênicos, vetores de transmissão de doenças, com sérios impactos na saúde pública.

Na verdade, o crescimento dos resíduos sólidos urbanos - RSU, no Brasil, registrou um aumento expressivo de 2009 para 2010 (Figura 9), superando a taxa de crescimento urbano populacional do país, que segundo estimativas do IBGE no censo realizado em 2010 ficou na casa um ponto percentual (IBGE, 2010).

Figura 9 - Geração de Resíduos Sólidos Urbanos no Brasil
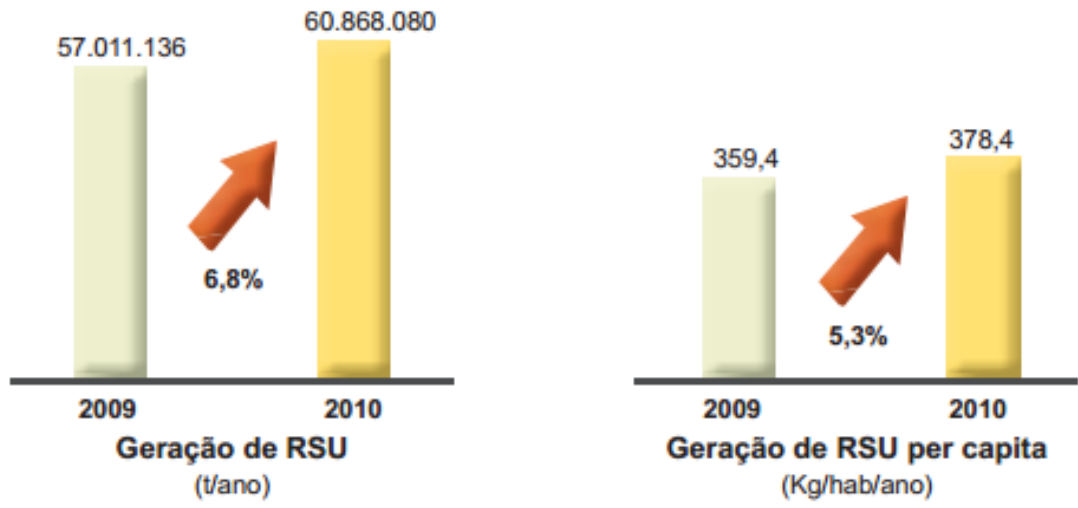

Fonte: Pesquisas ABRELPE 2009 e 2010 e IBGE (contagem da população 2009 e Censo 2010) 
A Figura 10 mostra que houve um aumento de 7,7\% na quantidade de RSU coletados em 2010, conforme demonstrado pela comparação com o total coletado em 2009. Na comparação entre o índice de crescimento da geração de RSU com o índice de crescimento da coleta, percebe-se que este último foi ligeiramente maior do que o primeiro, o que demonstra um discreto aumento na cobertura dos serviços de coleta de RSU no país.

Figura 10 - Coleta de RSU no Brasil
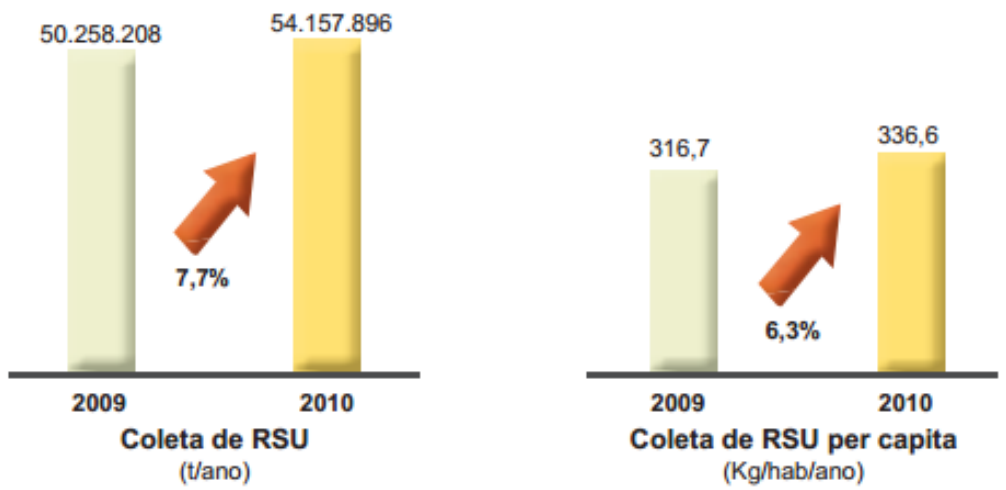

Fonte: Pesquisas ABRELPE 2009 e 2010 e IBGE (contagem da população 2009 e Censo 2010)

Conforme pode ser observado na Figura 11, em termos percentuais, houve uma discreta evolução na destinação adequada dos RSU no ano de 2010, em comparação ao ano de 2009. No entanto, a quantidade de RSU destinados inadequadamente cresceu e quase $\mathbf{2 3}$ milhões de toneladas de RSU seguiram para lixões ou aterros controlados, trazendo consideráveis danos ao meio ambiente. (grifos nossos)

Figura 11 - Destinação final dos resíduos sólidos no Brasil
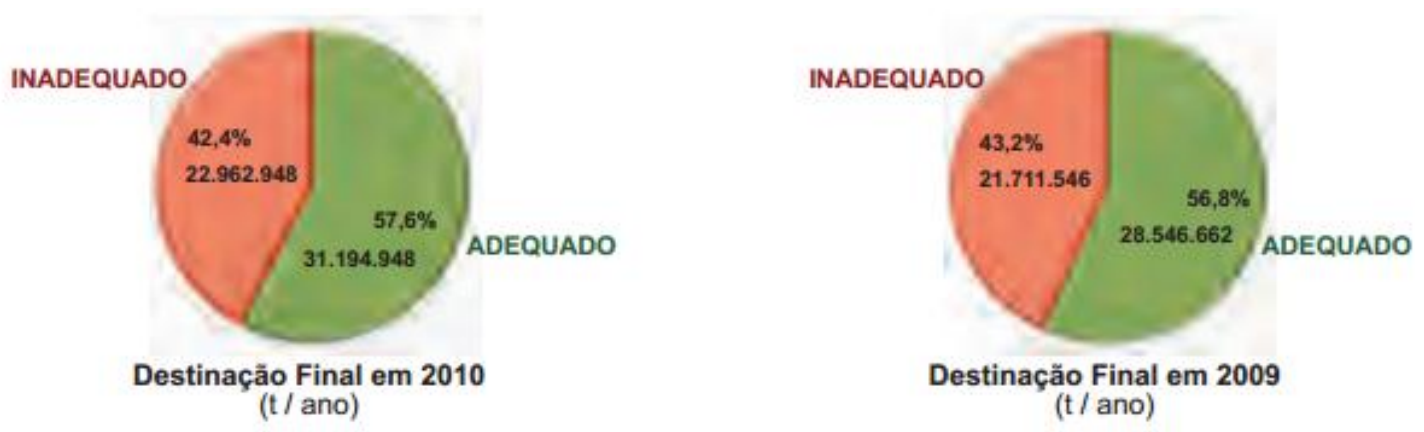

Fonte: Pesquisas ABRELPE 2010 e 2009 
O manejo inadequado dos RSU gera desperdícios, desigualdades sociais, contribui para ameaça constante à saúde pública e intensifica a degradação ambiental, comprometendo a qualidade de vida das populações, especialmente nos grandes e médios centros urbanos. Nesses grandes centros, especialmente nas Regiões Metropolitanas, o que se verifica é a carência de locais apropriados para disposição adequada dos RSU.

Ressalte-se que $61 \%$ dos municípios brasileiros ainda fazem uso de unidades de destinação inadequada de resíduos, encaminhando-os para lixões e aterros controlados, que pouco se diferenciam dos lixões, uma vez que ambos não possuem o conjunto de sistemas e medidas necessários para proteção do meio ambiente contra danos e degradações (ABRELPE, 2010).

No Brasil, até promulgação da Política Nacional de Resíduos Sólidos, em 2010, não houve diretrizes ou definições políticas para a área RSU em âmbito nacional. Para ser exato o que se tinha eram legislações pontuais e genéricas. Tal panorama associa-se à escassez de recursos técnicos e financeiros para o equacionamento do problema.

O que se tem, em verdade, são intervenções pontuais e desconcentradas, para ser mais imprecisas, desarticuladas sem direcionamento específico, com sobreposição de competências dos diferentes agentes públicos e baixa eficiência do processo decisório, demonstrando que o setor público carece de unidade quando o assunto é política pública para RSU.

Além do crescimento dos RSU e consequentemente de sua destinação inadequada, chame-se atenção que nos últimos anos, houve mudanças significativas em sua composição e características, aumentando o grau de sua periculosidade (OMS, 2010; EPA, 2010).

Tais alterações são resultados dos modelos de desenvolvimento pautados pela obsolescência programada dos produtos, pelo modismo e pela mudança nos padrões de consumo excessivo e supérfluo. 
A situação evidencia a urgência em se adotar um sistema de manejo adequado dos resíduos, definindo uma política para a gestão e o gerenciamento, que assegure a melhoria continuada do nível de qualidade de vida, promova práticas recomendadas para a saúde pública e proteja o meio ambiente contra as fontes poluidoras.

O quadro apresentado na cidade de São Paulo mostra que o investimento da administração municipal não vai ao encontro da gestão integrada e sustentável dos RSU quando se trata dos resíduos domiciliares e que essa problemática necessita ser enfrentada em suas dimensões da sustentabilidade urbana, socioambiental e financeira. (JACOB \& BESEN, 2011).

Torna-se necessário definir estratégias para promover a redução de resíduos nas fontes geradoras, por meio de educação ambiental permanente, a coleta seletiva com inclusão de catadores e metas de redução de disposição de resíduos no solo, por meio de um plano de gestão abrangente, integrado e pactuado com a sociedade. (JACOB \& BESEN, 2011).

Dessa forma o que se tem na cidade de São Paulo é ausência de política pública, de estratégias e de uma visão de planejamento para o equacionamento da gestão dos resíduos. É consenso entre os especialistas na área de resíduos sólidos a urgência em equacionar o problema do tratamento e da destinação final do lixo. 
3.2 Caracterização do projeto MDL do Aterro Sanitário Bandeirantes

Antes mesmo de iniciar a caracterização do projeto de MDL do aterro sanitário Bandeirantes é necessário realizarmos um esclarecimento de ordem técnica acerca da definição de aterro sanitário, aterro controlado e lixão.

A Associação Brasileira de Normas Técnicas (ABNT 1984) define aterro sanitário como conjunto de "técnicas de disposição de RSU no solo, sem causar danos à saúde pública e sua segurança, minimizando os impactos ambientais, método este que utiliza princípios de engenharia para confinar os resíduos sólidos a menor área possível e reduzi-los ao menor volume permissível, cobrindo-os com uma camada de terra na conclusão de cada jornada de trabalho, ou a intervalos menores se for necessário”.

Tal técnica diminui a proliferação de micro e macro vetores, minimizando os riscos de contaminação direta, além de permitir o controle efetivo da poluição do ar, fumaça e odores, por meio da drenagem de gases, reduzindo os riscos de incêndio, a poluição das águas superficiais e subterrâneas, por meio da utilização tecidos sintéticos que impermeabilizam o solo e drenagem do material percolado, gerando a possibilidade de destinar ou dar tratamento a produção de chorume (líquido resultante da decomposição do resíduo orgânico).

A figura 12 mostra de forma esquemática o funcionamento de um aterro sanitário, caracterizando uma célula dessa obra de engenharia. Destaque para o sistema de drenagem que envolve o dreno de gás ( produção pela decomposição dos resíduos), a drenagem pluvial ou superficial (a água de chuva de ser captada para que não haja muita infiltração na célula) e a drenagem do chorume e o sistema de impermeabilização com a utilização de mantas, argila, tecidos sintéticos, impermeabilizantes de polietileno de alta densidade (PEAD) que revestem o aterro sanitário. 
Figura 12 - Esquema de um aterro sanitário

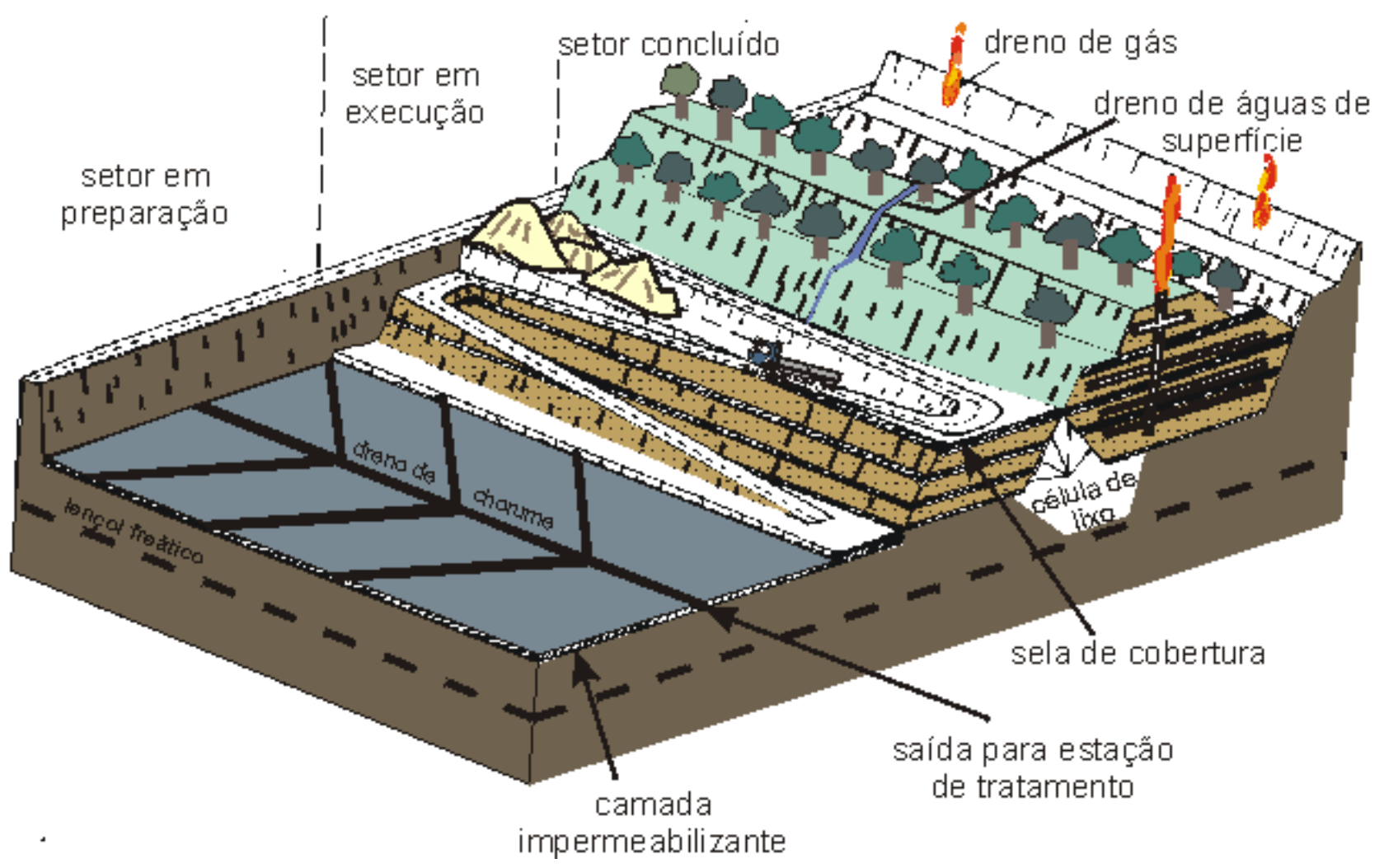

Fonte: (Proin/Capes \& Unesp/IGCE, 1999).

A diferença básica entre um aterro sanitário e um aterro controlado é que no último não existe efetivamente a coleta e tratamento do chorume, assim como da drenagem e queima do biogás. Na realidade o único controle que existe é apenas a vetores mecânicos. Diversos estudiosos criticam a existência do aterro controlado e de sua definição por acreditarem que este é um lixão, não devendo, sequer que existir tal diferenciação de classificação.

As Figuras 13 e 14 apresentam um comparativo entre um aterro sanitário e um aterro controlado, mostrando e ressaltando as diferenças acima relatadas. 
Figura 13 - Modelo esquemático de um aterro controlado

\section{Aterro Controlado}

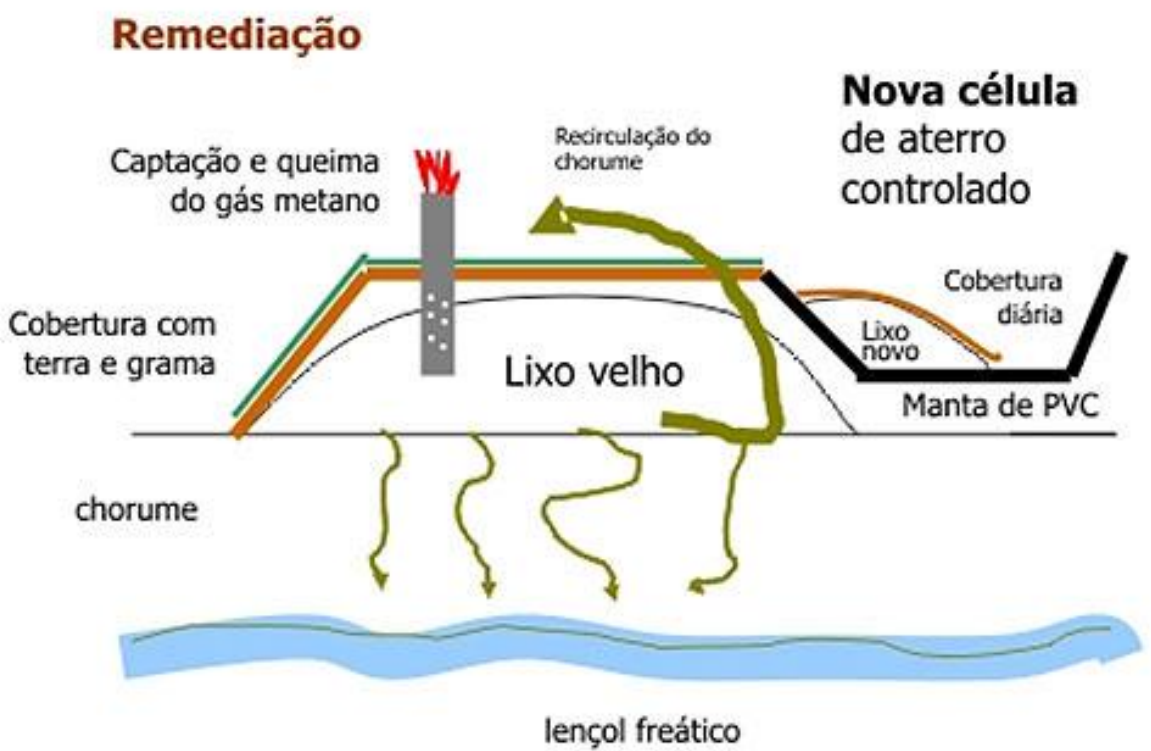

Fonte: Plano de Gestão Integrada de Resíduos Sólidos de Santa Rita do Sapucaí -2008

Figura 14 - Modelo esquemático de um aterro sanitário

\section{Aterro Sanitário}

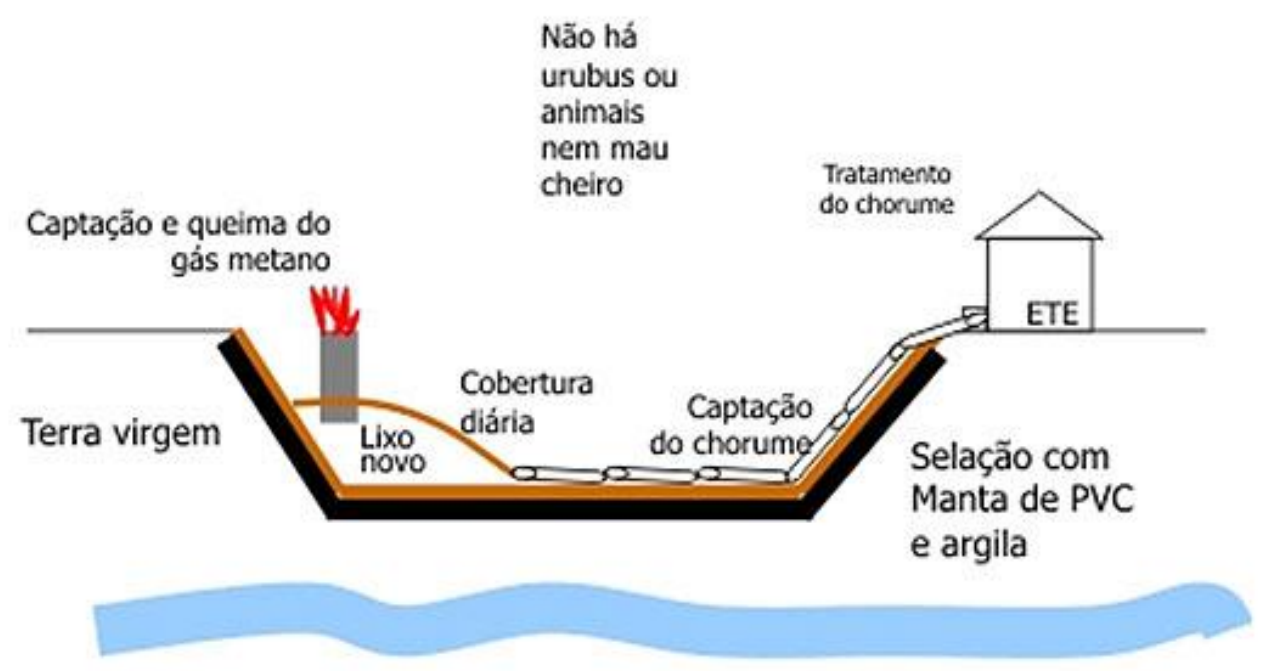

Não há contaminação do lençol freático

Fonte: Plano de Gestão Integrada de Resíduos Sólidos de Santa Rita do Sapucaí -2008 
É de fácil constatação que no aterro sanitário existem técnicas que visam coibir a contaminação, bem como a permeabilização do chorume, enquanto no aterro controlado, a única preocupação é apenas a cobertura do RSU, não havendo que se falar em técnica adequada de disposição dos resíduos sólidos. Mesmo havendo consenso de que o aterro controlado é uma destinação inadequada dos RSU sua utilização é verificada em larga escala no Brasil, principalmente nos municípios que coletam até 50 toneladas/dia de RSU. O lixão, por sua vez, é uma forma ambientalmente inadequada de disposição de RSU no solo, acarretando problemas à saúde pública e um impacto ambiental de dimensão incalculável.

Dentre os diversos setores para a análise de projetos no âmbito do MDL, se destaca o aterro sanitário, por apresentar maior relação custo-benefício ambiental. Ainda que o aporte inicial de capital investido seja mais alto, os projetos têm longa duração. Cabe ser ressaltado que o gás metano é 21 vezes mais impactante que o $\mathrm{CO}_{2}$ (DUARTE, 2006).

Os projetos de MDL no Brasil começaram em junho de 2004, com a aprovação do projeto da Nova Gerar na Baixada Fluminense do Rio de Janeiro e do Projeto Soteropolitano, Veja, na capital Baiana, ambos com o objetivo de gerar energia através do aproveitamento de biogás produzido em aterro sanitário (UNFCCC).

Os créditos de carbono são uma fonte economicamente viável para implantação de sistemas de geração de energia elétrica em aterros sanitários e de recuperação ambiental de lixões.

Os projetos do MDL atrelados a aterros sanitários foram os primeiros a serem implementados e estão entre os mais significativos pelo fato de adicionarem a problemática das mudanças climáticas os pontos relacionados às questões socioambientais fundamentais e de difícil resolução (SOUZA, 2007).

O Mecanismo de Desenvolvimento Limpo (MDL) empregado à Redução de Emissões de Gases gerados em aterros sanitários antevê o cumprimento de estudos de viabilidade técnica, social, institucional e econômica para municípios brasileiros (IBAM, 2007). 


\subsubsection{A área do Aterro Sanitário Bandeirantes.}

$\mathrm{O}$ aterro sanitário Bandeirantes tem como coordenadas geográficas $23^{\circ} 25^{\prime} 35^{\prime \prime} \mathrm{S}$ e 46 45'22"W, situando na zona norte da cidade de São Paulo, no km 26,5 da Rodovia dos Bandeirantes, estrada que conecta a cidade de São Paulo a Campinas.

As Figuras 15 e 16 a seguir mostram respectivamente a caracterização da área do município de São Paulo e a região do entorno do empreendimento objeto de estudo deste trabalho.

Figura 15: Divisão político administrativa dos municípios do Estado de São Paulo-SP

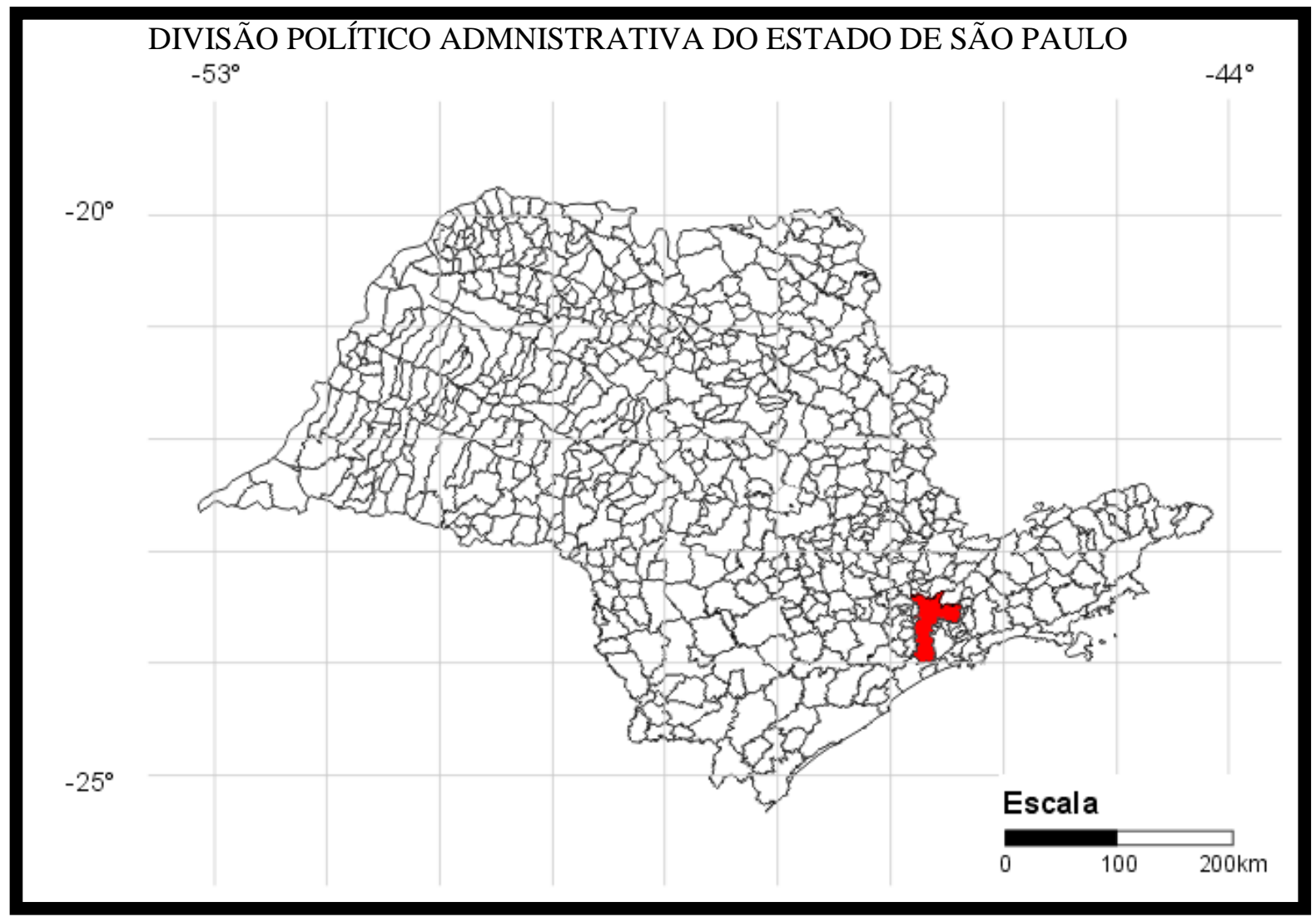

Fonte: IBGE, 2009 
Figura 16: Distritos do Município de São Paulo

\section{DISTRITOS DO MUNICÍPIO DE SÃO PAULO}

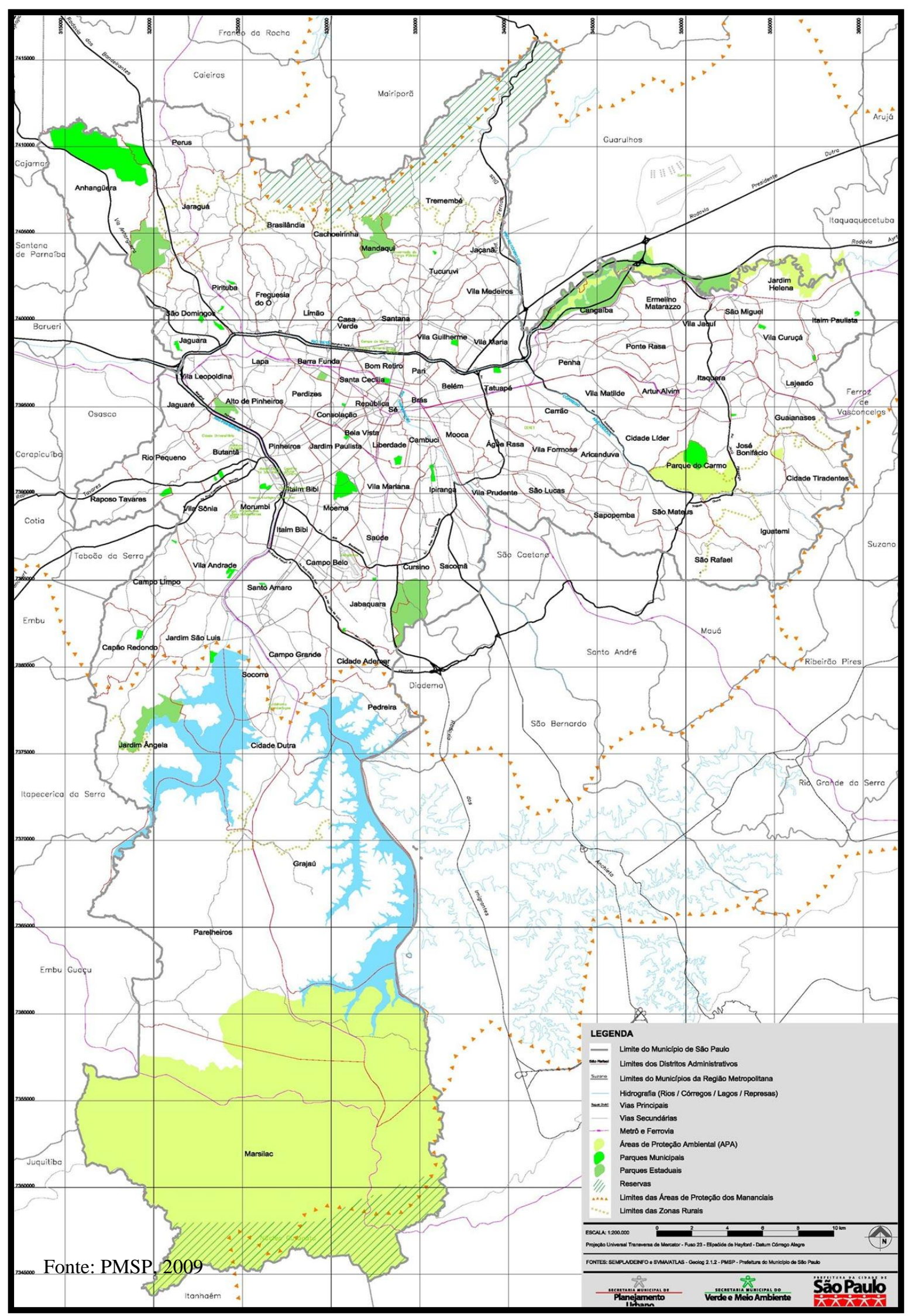


Figura 17: Região de Perus, Município de São Paulo-SP

REGIÃO DE PERUS SÃO PAULO - SP

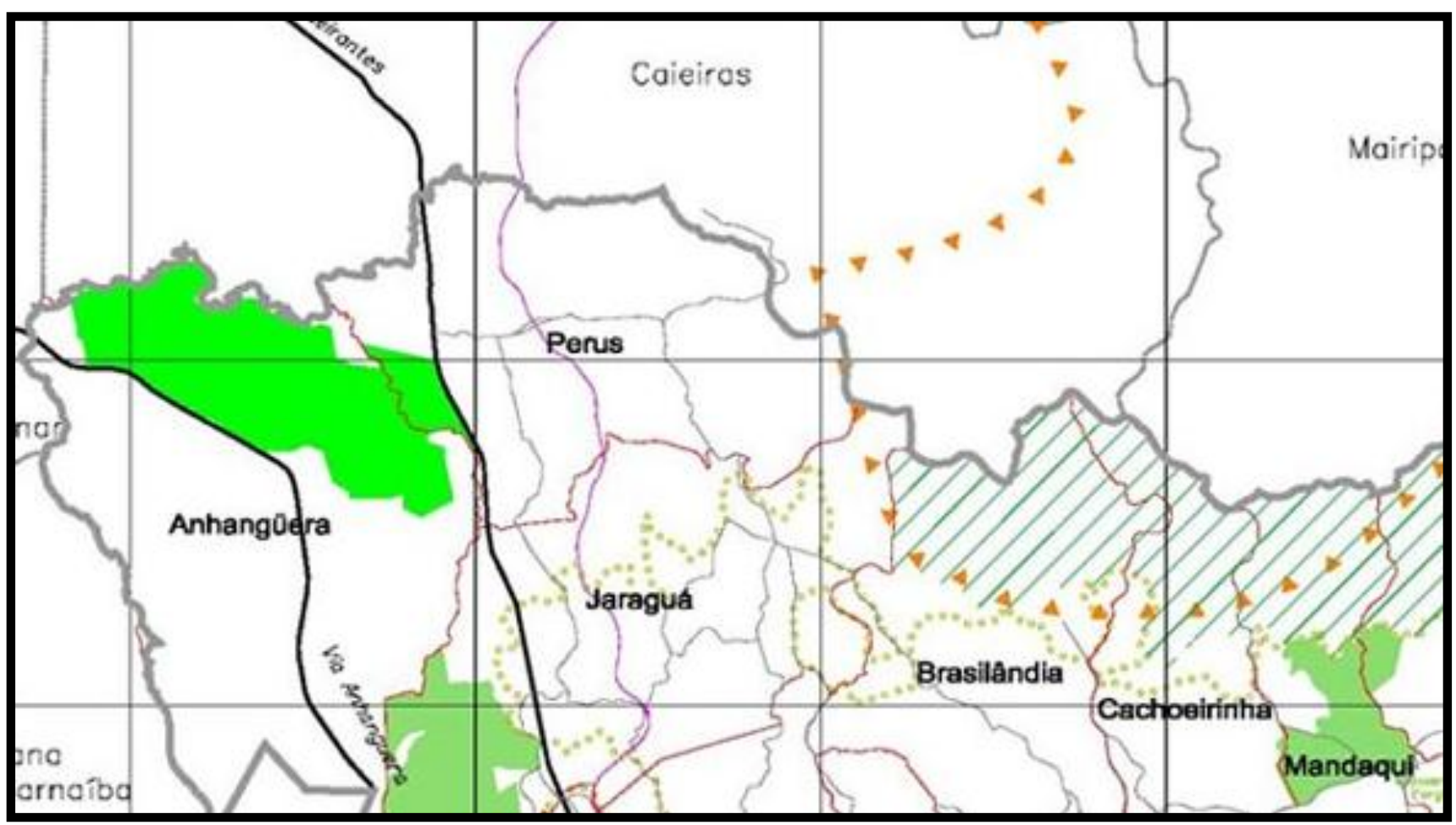

Fonte: PMSP, 2009

Figura 18: Aterro Sanitário Bandeirantes - SP (A área em vermelho corresponde aos limites do aterro sanitário)

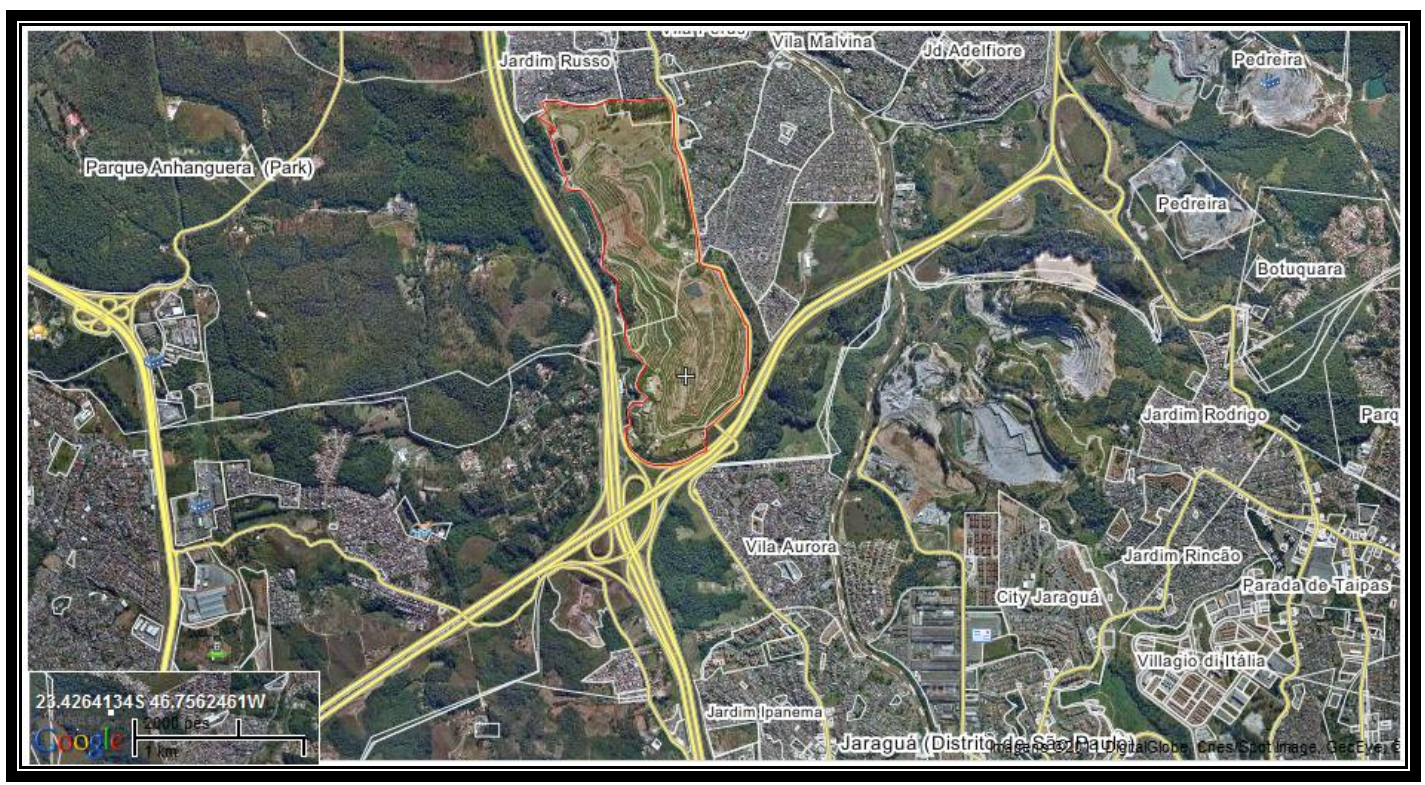

Fonte: Google Maps, 2011 
Este aterro cobre uma área de aproximadamente 1,35 milhões de $\mathrm{m}^{2}$, possuindo como fronteira norte a região urbana de Perus, localizada na zona oeste da cidade de São Paulo (Figura 17 e 18).

Perus é o bairro mais setentrional de São Paulo, situado na região do Vale do Rio Juquery e da Serra Cantareira.

A Subprefeitura de Perus abarca, cerca de 110 mil habitantes entre os distritos de Perus e Anhanguera. O distrito de Perus tem 65.581 habitantes e Anhanguera registra 71.148.

Tabela 6: População, Taxa de Crescimento, Total de Moradias da região de Perus

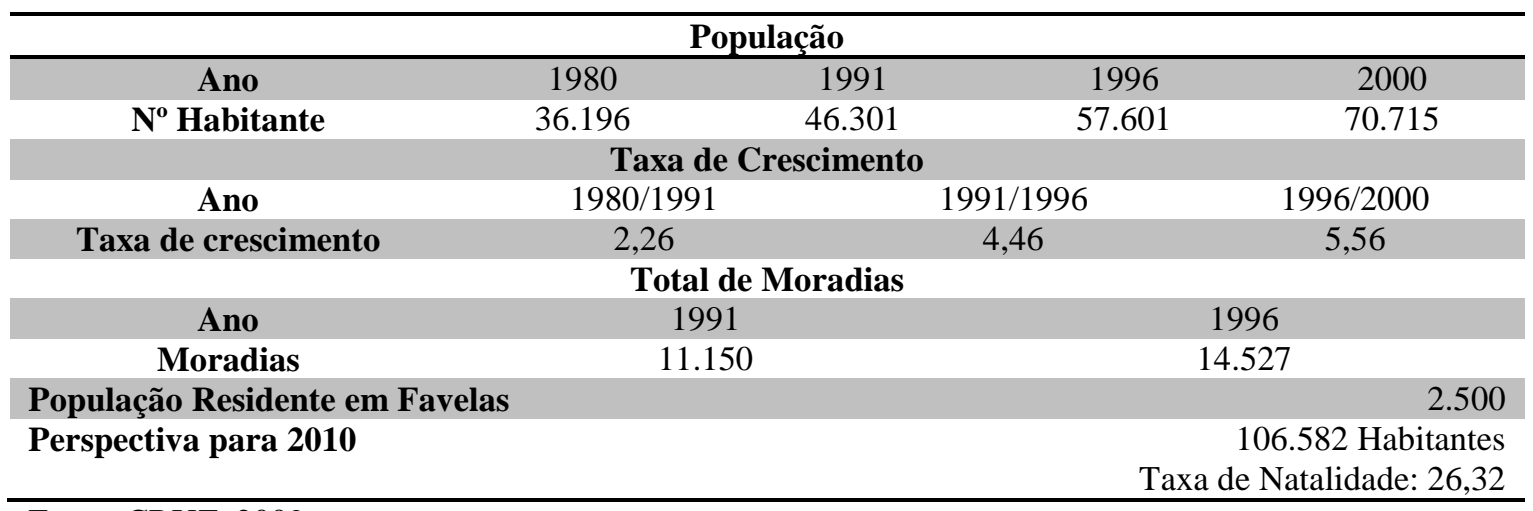

Fonte: CRUZ, 2009

\subsubsection{Histórico do Aterro}

A operação deste aterro foi iniciada no ano de 1979. No início da década de 80, o aterro recebia cerca de 4.000 a 5.000 toneladas de resíduos por dia (BARREIRA, L. P., PHILIPPI JR, 2001). O aterro foi desativado no ano de 2006, devido a sua capacidade de 30 milhões de toneladas terem sido ultrapassadas, e assim, sua vida útil ter chegado ao fim (PDD, 2005). 
Os resíduos sólidos do aterro eram originários, principalmente da região de transbordo Ponte Pequena e das Subprefeituras de Perus, Pirituba/Jaraguá e da Freguesia do Ó (PAVAN \& PARENTE, 2006) e (CETESB, 2005).

Devido à grande concentração de resíduos sólidos que este aterro possui, ele pode ser visto como um grande biorreator decorrente da biodegradação da matéria orgânica existente no lixo, em ambiente anaeróbio. Desta reação de biodegradabilidade, resulta a geração do biogás de lixo, que é composto essencialmente de $\mathrm{CO}_{2}$ (dióxido de carbono) e $\mathrm{CH} 4$ (metano) (FERRUCCIO, 2003).

Mas, somente em 2003 iniciou-se a captação de gás do aterro, com o objetivo de geração de energia. Por meio de uma parceria Público Privada, a Prefeitura Municipal de São Paulo, bem como a Biogás tomaram a frente do projeto para obtenção de energia.

Entre os parceiros do projeto estão: Biogás Arcadis Logos Engenharia (grupo Arcadis), empresa holandesa especializada em engenharia, gestão de projetos e consultoria; a Heleno \& Fonseca SA, empresa brasileira de construção; e Van der Wiel, outra empresa holandesa atuando nos domínios de transporte, infraestrutura técnica e ambiental especializada em projetos de desgaseificação (PDD, 2005). A Prefeitura de São Paulo foi adicionada como participante, uma vez que é proprietária de 50\% das reduções de emissão geradas pelo projeto (PDD, 2005).

\subsubsection{O Projeto Bandeirantes}

O Projeto de MDL para o aterro sanitário Bandeirantes só foi viável graças a capacidade que os aterros sanitários possuem produzir gás metano, mesmo muitos anos após o encerramento das atividades operacionais do empreendimento. No sítio em questão a média anual de redução de toneladas de $\mathrm{CO}_{2}$ é da ordem de 1.070.629 (PDD, 2005). 
Cabe ser ressaltado que o grupo Itaú Unibanco é responsável pela gestão energética do biogás que tem capacidade para gerar energia elétrica de $22 \mathrm{MW}$. A quantidade estimada de reduções de Gases de Efeito Estufa (GEE) pelo projeto é da ordem de 7.494 .404 toneladas de $\mathrm{CO}_{2}$ e para o primeiro período (7 anos) de obtenção de créditos (CRUZ \& PAULINO, 2010).

O projeto Bandeirantes de Gás de Aterro e Geração de Energia, que tem uma vida operacional esperada de 21 anos, teve como clientes a KFW Bankengruppe (empresa alemã) e a Fortis (empresa holandesa) como compradoras de seus créditos.

Em 2001, o Grupo Biogás Energia Ambiental S.A foi o vencedor do processo de licitação para exploração do uso do biogás do aterro municipal Bandeirantes. A concessão de serviço público determina que a empresa repasse 50\% dos RCEs emitidos à PMSP e pague uma taxa mensal a título de exploração do uso da área e de exploração do biogás, Tabela 7 (CRUZ \& PAULINO, 2010).

A Biogás Energia Ambiental S.A. (Tabela 8), que é fruto da composição de três diferentes grupos empresariais distintos (Heleno \& Fonseca Construtécnica S/A; Arcadis Logos Energia S/A e Van Der Wiel), foi estabelecida em 2004, após a assinatura do contrato de concessão com a Prefeitura Municipal de São Paulo para exploração de gás do Aterro Sanitário Bandeirantes (PDD, 2005).

Tabela 7: Divisão dos CERs concebidos

\begin{tabular}{|c|c|c|c|c|c|}
\hline \multirow[b]{2}{*}{ Período } & \multicolumn{5}{|c|}{ Aterro Bandeirantes } \\
\hline & $\begin{array}{c}\text { CERs } \\
\text { emitidos }\end{array}$ & $2 \%$ UNFCCC & Distribuição & PMSP & Biogás \\
\hline Jan 04/ Fev 06 & 1.150 .144 & 23.003 & 1.127 .141 & 563.571 & 563.570 \\
\hline Mar 06/ Set 06 & 377.234 & 7.545 & 369.689 & 184.845 & 184.844 \\
\hline Out 06/ Dez 06 & 142.928 & 2.859 & 140.069 & 70.035 & 70.034 \\
\hline Jan 07/ Jun 07 & 356.638 & 7.133 & 349.505 & 174.753 & 174.752 \\
\hline Jul 07/Out 07 & 249.612 & 4.992 & 244.620 & 122.310 & 122.310 \\
\hline Nov 07/Dez07 & 120.514 & 2.410 & 118.104 & 59.052 & 59.052 \\
\hline Jan 08/ Mar 08 & 181.273 & 3.625 & 177.648 & 88.824 & 88.824 \\
\hline Abr 08/Jun 08 & 150.553 & 3.011 & 147.542 & 73.771 & 73.771 \\
\hline Total & 2.728 .896 & 54.578 & 2.674 .318 & 1.337 .160 & 1.337 .158 \\
\hline
\end{tabular}

Fonte: CRUZ, 200 
Tabela 8: Participantes do Projeto de MDL do aterro sanitário Bandeirantes

\begin{tabular}{cc}
\hline Participantes & Setor de atuação \\
\hline $\begin{array}{c}\text { Heleno e Fonseca } \\
\text { Construtécnica S/A }\end{array}$ & $\begin{array}{c}\text { Atua no segmento de construção de obras civis e } \\
\text { no desenvolvimento de projetos de implantação } \\
\text { e gestão de operação de aterros sanitários } \\
\text { Arcadis Logos } \\
\text { Energia S/A }\end{array}$ \\
$\begin{array}{c}\text { Com foco direcionado à estruturação de negócios e } \\
\text { desenvolvimento de projetos, criada dentro de } \\
\text { conceitos do novo modelo para o setor energético } \\
\text { em implantação no Brasil }\end{array}$ \\
Van Der Wiel & $\begin{array}{c}\text { Segmentos: transportes, infraestrutura e tecnologia } \\
\text { ambiental }\end{array}$ \\
\hline Fonte: CRUZ, 2009 &
\end{tabular}

A empresa Biogás Energia Ambiental S/A captura e direciona o gás obtido no aterro sanitário à moto-geradores de até $12.000 \mathrm{~m}^{3} / \mathrm{h}$ de biogás, com um conteúdo mínimo de $50 \%$ de metano, por 24h/dia em 365 dias/ano (PDD,2005). O biogás produzido é empregado para ativar 24 conjuntos motogeradores de $925 \mathrm{Kw} /$ conjunto correspondendo a uma potência líquida de $20.000 \mathrm{Kw}$, energia satisfatória para abastecer aproximadamente 400.000 habitantes (ITAÚ UNIBANCO HOLDING AS, 2006).

Ao se realizar uma comparação com a descrição contida nos documentos de concepção dos projetos, DCPs, nos quais é feita uma estimativa de geração de $\mathrm{tCO}_{2} \mathrm{e}$, com os valores mencionados nos relatórios de monitoramento, a geração efetiva de reduções não cumpre com a estimativa prevista, tendo um rendimento de menos da metade da meta estabelecida (CRUZ \& PAULINO, 2010) (Figura 19).

Um dos motivos que pode explicar esse descompasso de valores estimados versus gerados é a composição do lixo, que apesar de em sua grande parte ser de matéria orgânica (que originará o biogás), têm-se outros materiais adjuntos e devido à cidade de São Paulo ainda não ter uma coleta seletiva satisfatória, resíduos de diferente natureza acabaram depositados no aterro, prejudicando iniciativas como estas de geração de energia através da captura do biogás (CRUZ \& PAULINO, 2010). 
Figura 19: Aterro Bandeirantes: comparação entre $\mathrm{tCO}_{2} \mathrm{e}$ estimadas no documento de concepção dos projetos (DCPs) e efetivamente geradas nos Relatórios de Monitoramento.

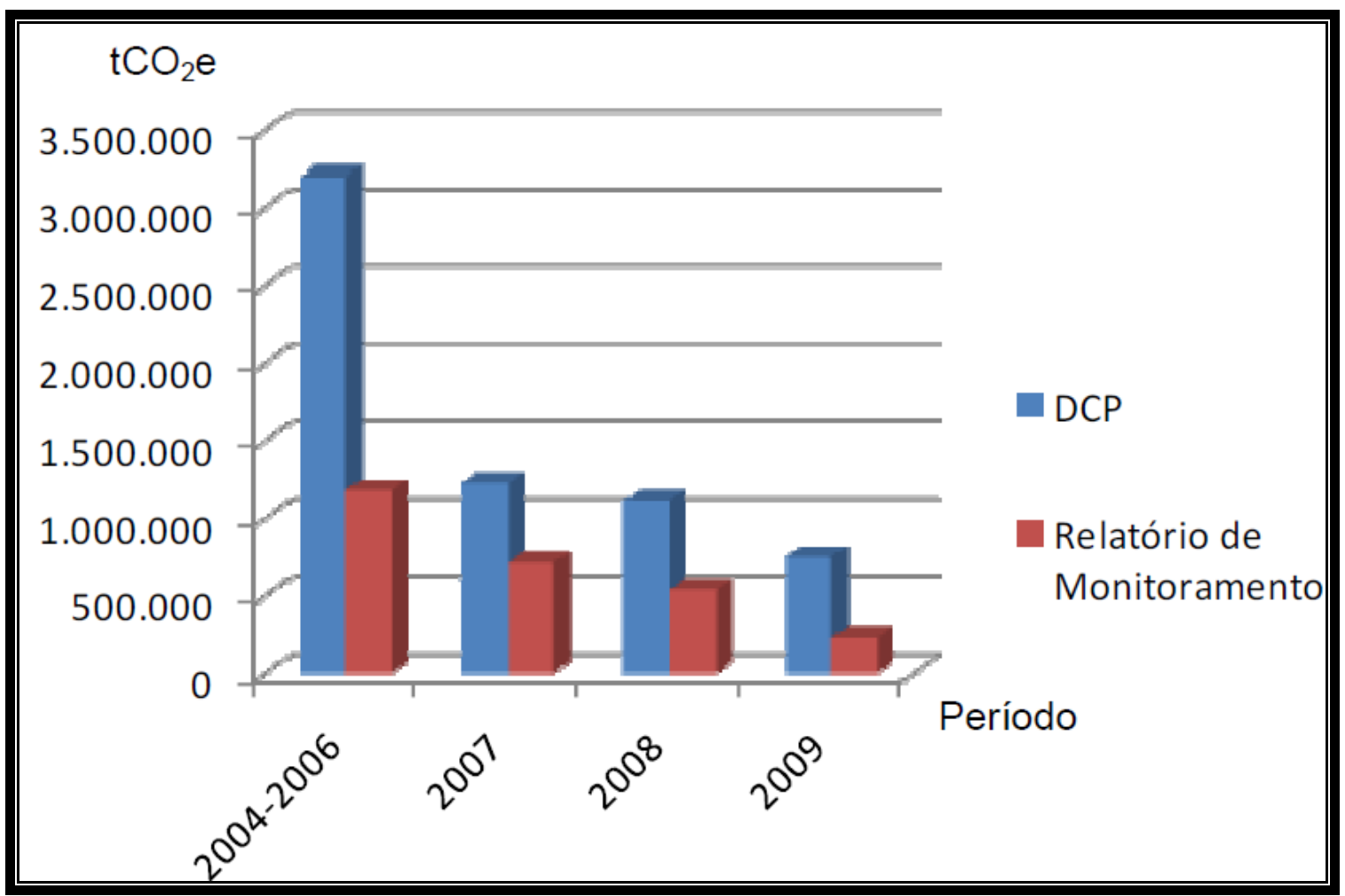

Fonte: CRUZ, 2009

\subsection{O Projeto Plantar}

O Projeto Plantar é fruto de uma parceria conjunta entre o Protocol Carbon Fund (PCF), instituto do Banco Mundial, e Plantar Siderúrgica S.A, empresa do Grupo Plantar. Estão diretamente ligadas ao projeto duas empresas do grupo a Plantar S.A. Reflorestamentos que é a responsável pelo suprimento de madeira de eucalipto que abastece os fornos da Plantar Siderúrgica S.A. Essa madeira renovável é, atualmente, a única fonte termorredutora para a fabricação de ferro gusa. 
Com o fim dos incentivos fiscais do Governo Estadual para o plantio de eucaliptos, ocorrido em meados da década de 1990, a utilização de carvão vegetal renovável como matériaprima para a indústria siderúrgica havia se tornado impraticável do ponto de vista econômico.

Tal projeto visou a utilização dos benefícios ligados ao MDL, em especial o financiamento estrangeiro para o desenvolvimento de novas tecnologias, para a viabilização da produção de ferro gusa tendo o carvão vegetal à base de eucalipto como matéria-prima termorredutora.

A parceria com o Banco Mundial só foi estabelecida em 2002 quando foi cumprida pela Empresa a exigência do Banco de que esta adequasse sua produção à práticas em termos de responsabilidade socioambiental vigentes no mundo.

É nessa realidade que a empresa intensifica a busca pela certificação de suas atividades de acordo com as normas ISO e, principalmente, adequação do seu manejo florestal no intuito de obter a certificação FSC (VENTURA \& ANDRADE, 2008).

O Projeto compreende o estabelecimento de aproximadamente 21.800 hectares de plantações de eucalipto dedicadas à produção de carvão vegetal, um biocombustível sólido e renovável, que serão utilizados na produção de aproximadamente 240.000 toneladas/ano de ferro gusa.

Visa contribuir para a mitigação do aquecimento global e deverá reduzir a concentração de $\mathrm{CO}_{2}$ equivalente na atmosfera em mais de 12 milhões de toneladas, por meio de sumidouros de carbono e pelas reduções de emissão na indústria. Aproximadamente metade da área dos plantios ocorreu em áreas de pastagens implantadas antes de 1990, e a outra metade em áreas de florestas de eucalipto que se encontrava em sua última rotação e que também foram implantadas antes de 1990. 


\subsection{1 Área de abrangência}

O Projeto Plantar abrange a área plantada para reflorestamento que se localiza nas Unidades de Curvelo (MG02), Felixlândia (MG03) e Morada Nova de Minas (MG04), todas no Estado de Minas Gerais que totalizam 21.845,31 hectares (Figuras 20 a 22).

Figura 20: Mapa do Estado de Minas Gerais

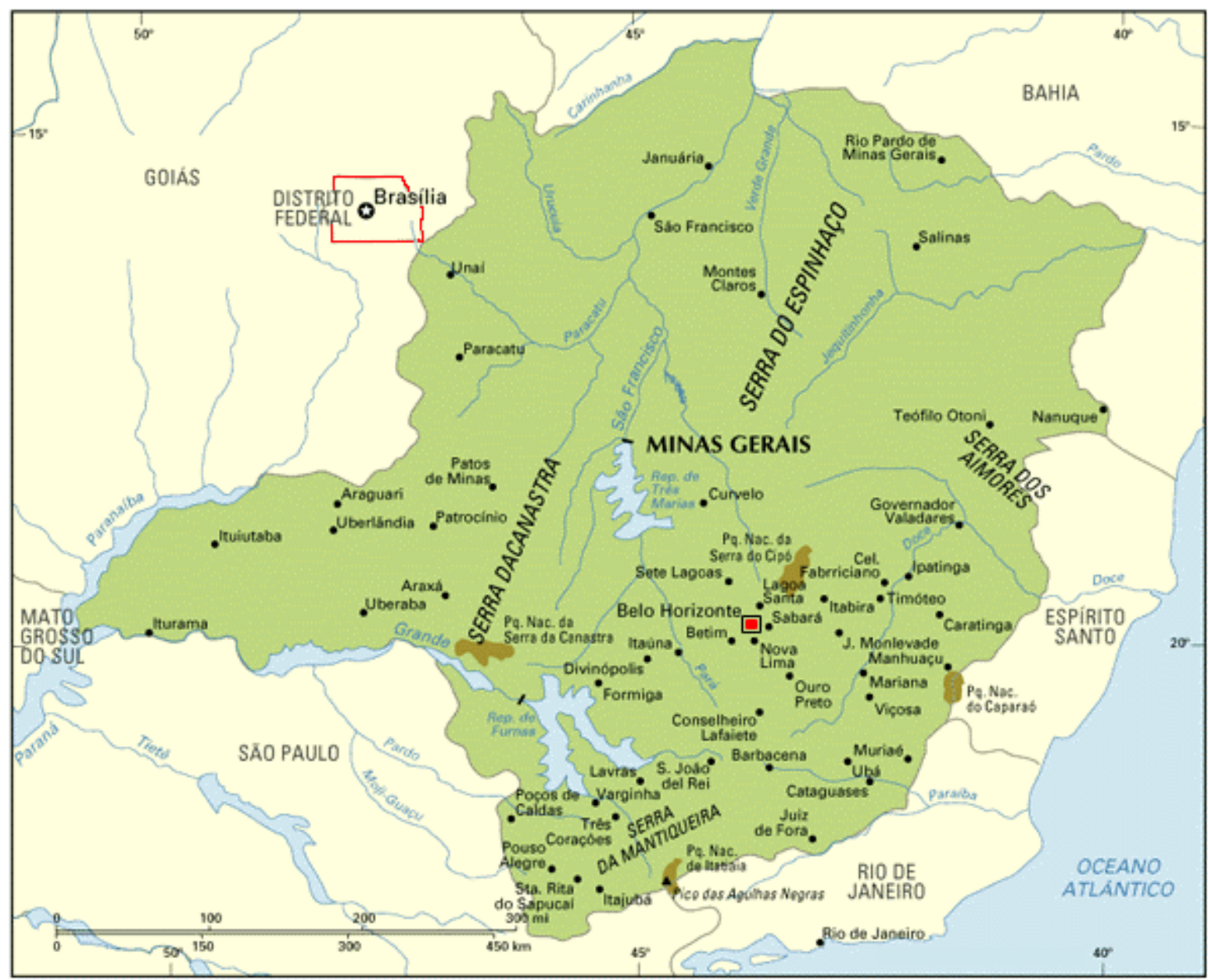

Fonte: Estado de Minas Gerais, 2009 
Figura 21: Região do Projeto Plantar - Cidades de Curvelo, Felixlândia e Morada Nova de Minas.

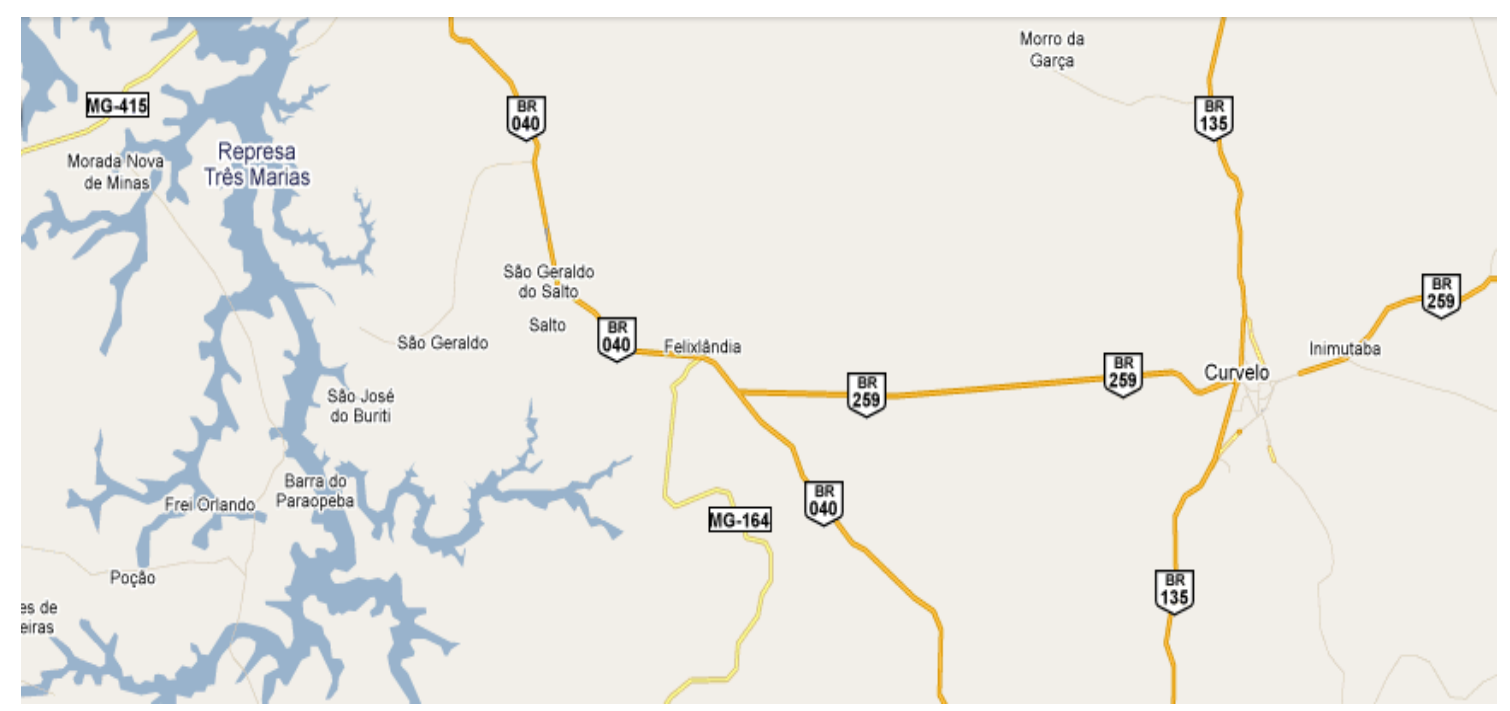

Fonte: Google Maps 2011

Figura 22: Região do Projeto Plantar (satélite) - Cidades de Curvelo, Felixlândia e Morada Nova de Minas

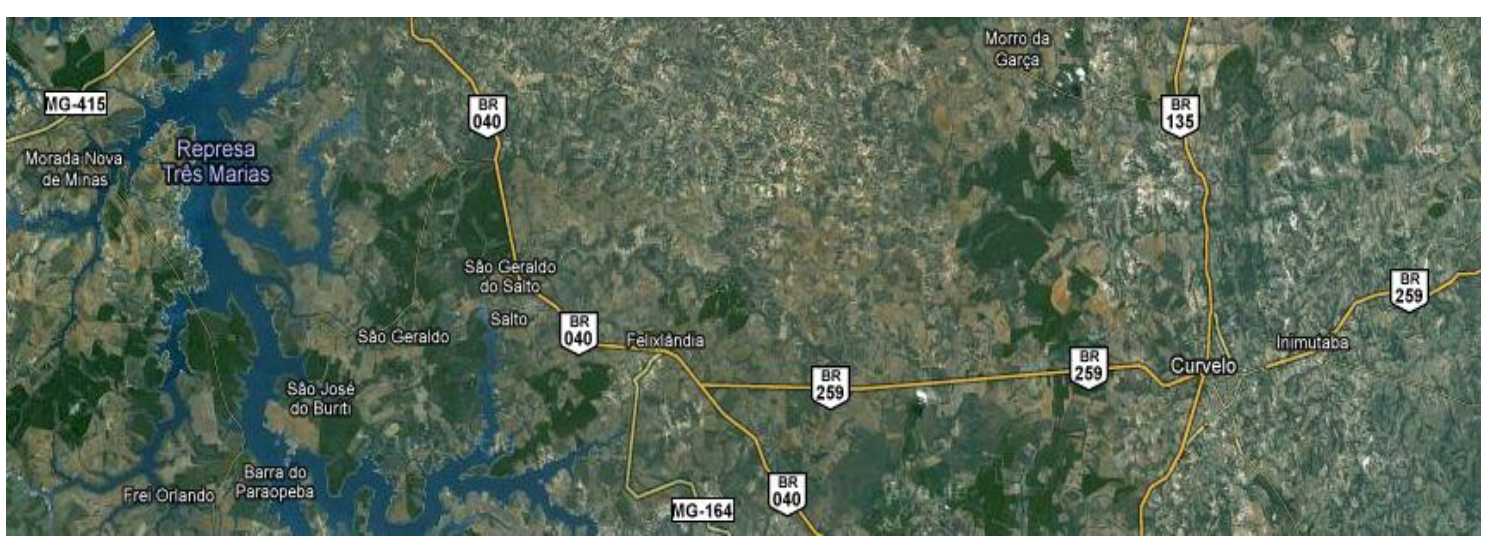

Fonte: Google Maps 2011 
A Tabela 9 apresenta os detalhes de uso e ocupação do solo das três áreas do projeto, conforme a certificação do FSC (GRUPO PLANTAR, 2010).

Tabela 9: Classificação e Uso do solo nas áreas do projeto Plantar.

\begin{tabular}{|c|c|c|c|c|c|c|c|}
\hline \multirow{3}{*}{\multicolumn{2}{|c|}{ Propriedade/ Município }} & \multicolumn{6}{|c|}{ Classificação - Uso e Ocupação do solo } \\
\hline & & \multirow[t]{2}{*}{$\begin{array}{l}\text { Áreas de } \\
\text { plantio } \\
\text { (ha) }\end{array}$} & \multicolumn{3}{|c|}{$\begin{array}{c}\text { Áreas de } \\
\text { Conservação/ Preservação } \\
\text { (ha) }\end{array}$} & \multirow[t]{2}{*}{$\begin{array}{l}\text { Outros } \\
\text { (ha) }\end{array}$} & \multirow[t]{2}{*}{$\begin{array}{l}\text { Total } \\
\text { (ha) }\end{array}$} \\
\hline & & & $\mathrm{RL}$ & APP & AC & & \\
\hline$\stackrel{⿱ ⺌}{\stackrel{O}{0}}$ & $\begin{array}{l}\text { Faz. Buenos } \\
\text { Aires/Outras } \\
\text { Curvelo e } \\
\text { Felixlândia }\end{array}$ & $9.660,61$ & $2.960,75$ & 300,66 & 307,23 & 969,55 & $14.198,80$ \\
\hline \multirow{2}{*}{$\stackrel{\text { 岁 }}{\stackrel{0}{0}}$} & $\begin{array}{l}\text { Faz. Jacaré } \\
\text { Felixlândia }\end{array}$ & $6.240,01$ & $2.148,92$ & 223,98 & 941,75 & 576,99 & $10.131,65$ \\
\hline & $\begin{array}{c}\text { Faz.Riachão } \\
\text { Felixlândia }\end{array}$ & 45,21 & 130,00 & 28,81 & 0,00 & 450,46 & 654,48 \\
\hline \multirow{2}{*}{ 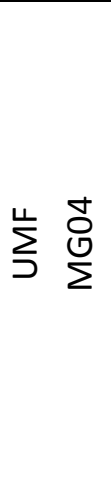 } & $\begin{array}{l}\text { Faz. Buriti } \\
\text { Grande } \\
\text { Morada Nova } \\
\text { de Minas e } \\
\text { Biquinhas }\end{array}$ & $5.328,48$ & $1.770,92$ & 732,97 & 289,20 & 453,78 & $8.575,35$ \\
\hline & $\begin{array}{c}\text { Faz. } \\
\text { Vitória/Guariba } \\
\text { Morada Nova } \\
\text { de Minas }\end{array}$ & 571,00 & 144,01 & 5,05 & 0,00 & 0,00 & 720,06 \\
\hline \multicolumn{2}{|r|}{ TOTAL } & $21.845,31$ & $7.154,6$ & 1291,47 & 1538,18 & 2450,78 & $34.280,34$ \\
\hline
\end{tabular}

Fonte: Grupo Plantar, 2010 


\subsubsection{O entendimento do Projeto Plantar}

Considera-se que o Projeto Plantar inaugurou o mercado de créditos de carbono no Brasil (IETA, 2006). O Projeto Plantar, de acordo com seus idealizadores teria sido escolhido pelo PCF em virtude da grande possibilidade de replicação de sua metodologia em siderúrgicas localizadas em outros países do mundo (GRUPO BANCO MUNDIAL, 2002).

O Brasil é um dos poucos países do mundo que possuem tecnologia em escala necessária para produção de ferro e aço à base de carvão vegetal. Cabe ser ressaltado que o coque proveniente de carvão mineral, além de não renovável, tem um alto custo ambiental e social em sua extração e processamento, uma vez que há emissão de carbono e a contaminação por enxofre. O carvão vegetal, por sua vez, sendo extraído de florestas plantadas, representa um recurso renovável e praticamente inesgotável de recursos, desde que adotadas técnicas adequadas de manejo florestal (AMS, 2001).

Por sua vez, o incentivo do MDL, com suas receitas advindas da comercialização dos créditos de carbono, representaria uma importante fonte de recursos externos para promover o desenvolvimento limpo e sustentável da siderurgia, evitando-se o uso de fontes de energia nãorenováveis ou fósseis.

Desde sua concepção original, o Projeto Plantar tem como objetivo geral "reduzir as emissões de gases do efeito estufa por meio do estabelecimento de plantios sustentáveis de florestas de eucaliptos para suprir o uso de carvão vegetal na produção de ferro primário (GRUPO PLANTAR, 2007).

A concepção do Projeto prevê a redução de GEE e remoção de gás carbônico por meio de quatro atividades parcialmente integradas:

- Atividade Florestal: remoção e estoque de gás carbônico $\left(\mathrm{CO}_{2}\right)$ em 23.100 hectares de plantios sustentáveis de eucalipto. 
- Atividade de Carbonização: redução das emissões de metano $\left(\mathrm{CH}_{4}\right)$ no processo de produção do carvão vegetal, através de melhorias na eficiência do processo de produção.

- Atividade de Produção de Ferro Gusa: emissões de $\mathrm{CO}_{2}$ que foram evitadas através da utilização de carvão vegetal renovável (carbo-neutro) ao invés de coque ou biomassa nãorenovável no processo de produção do ferro gusa.

- Atividade de Regeneração do Cerrado: regeneração induzida de aproximadamente 400 hectares de vegetação nativa de cerrado, atividade piloto que poderá ou não reivindicar créditos de carbono (GRUPO PLANTAR, 2008).

O Projeto pretende a busca tanto da redução das emissões de GEE quanto a remoção de $\mathrm{CO}_{2}$ da atmosfera. As atividades acima descritas envolvem todo o processo produtivo do ferro gusa, desde o plantio de eucalipto, que será utilizado como fonte de energia para os fornos, até o estágio produtivo propriamente dito (VENTURA \& ANDRADE, 2008).

Conforme preconiza a Decisão 19 do Protocolo de Kyoto, os créditos de atividades florestais são contabilizados separadamente daqueles originários das atividades industriais. Por essa razão, a Plantar sentiu a necessidade de separar a metodologia de seu Projeto Global, para fins de apresentação à Autoridade Nacional Designada (AND) brasileira e ao Conselho Executivo de MDL, em três projetos distintos:

1) Mitigação de emissões de metano na produção de carvão vegetal;

2) Reflorestamento como fonte renovável de suprimento de madeira para uso industrial;

3) Mitigação de $\mathrm{CO}_{2}$ no processo de produção de ferro gusa, através do uso de carvão vegetal renovável (carbon-neutro) como fonte de energia termo-redutora (MCT, 2007). 


\subsubsection{Principais Críticas ao Projeto Plantar}

A legitimidade do Projeto Plantar é contestada por vários setores da sociedade ressaltando que os argumentos do Projeto Plantar são insuficientes enquanto projeto de MDL, pois não contribuem para a minimização das mudanças climáticas nem gera desenvolvimento sustentável para o Brasil.

Os setores que criticam e são contrários ao Projeto Plantar são compostos por representantes do estado de Minas Gerais, Bahia, Espírito Santo e Rio de Janeiro. Entre seus integrantes encontram-se: associações de geógrafos; pesquisadores da UFMG e da UFES; vereadores; deputados; organizações ambientalistas; organizações de defesa dos direitos humanos, dos direitos dos índios, de famílias carvoeiras e de trabalhadores de forma geral; associações de moradores; grupos de luta pelo campo e pela terra; e sindicatos de trabalhadores rurais.

Para esses setores existe uma incompatibilidade entre a monocultura do eucalipto e, de todos os projetos a ela relacionados, e o desenvolvimento sustentável. A seguir será realizada uma análise dos principais pontos que compõem os argumentos contrários ao Projeto Plantar.

\section{A)Incompatibilidade entre monocultura de eucaliptos e desenvolvimento sustentável}

O Mecanismo de Desenvolvimento Limpo tem como preceito basilar a contribuição para o desenvolvimento sustentável do país executante. No entanto, segundo os setores envolvidos que são contrários ao Projeto existem muitos impactos sociais e ambientais causados por estes projetos e pela indústria da silvicultura (monocultura de árvores). Por isso, esses projetos são totalmente inadequados para um mecanismo como o MDL, que reivindica ser promotor de desenvolvimento sustentável (SUPTILZ et al, 2004). 
Dessa forma a contínua expansão da monocultura de eucalipto em larga escala causa impactos negativos de caráter social, econômico, ambiental e cultural para as comunidades locais, pois há um conflito nítido no uso da terra entre o projeto e as comunidades tradicionais, ocasionando desemprego, uma vez que o ciclo efetivo de mão de obra dessa cultura se concentra no plantio e no corte, havendo um intervalo de dois anos. Ainda, sendo o eucalipto uma espécie exótica, não permite a sobrevivência da fauna e da flora local, acabando com a biodiversidade e o uso de agrotóxicos nas plantações causa danos à água e ao solo, prejudicando, por conseguinte, as populações locais (ACPO et al, 2003; AGB et al, 2003; SPUTITZ et al, 2004; WRM, 2006; OVERBEEK, 2007b).

B) Contestabilidade da certificação FSC para comprovar a sustentabilidade das plantações de eucalipto

Em realidade, a relação dos críticos para com a Plantar iniciou-se com uma investigação à respeito da certificação FSC, onde se concluiu pela necessidade de revisão nos critérios e princípios utilizados pelo selo.

Os certificados do selo "verde" FSC que supostamente estabelecem que o manejo das plantações deve ser ambientalmente adequado, socialmente responsável e economicamente viável, são altamente questionáveis (SUPTITZ, 2004).

Durante todo o processo de coleta de dados e informações sobre as estratégias de regulação de conflitos socioambientais utilizados pela Plantar, constatou-se grande interação entre o Projeto Plantar e a certificação das florestas da Plantar pelo FSC. No próprio Documento de Concepção do Projeto, a Plantar declara que a certificação de bom manejo florestal seria uma comprovação da sustentabilidade de suas plantações. (VENTURA \& ANDRADE, 2008)

O "acaso" de ter sido escolhida como uma das empresas representantes, no Brasil, de uma análise detalhada sobre o manejo florestal de plantações em larga escala, justamente no momento em que estava pleiteando financiamento, via um dos órgãos de um dos principais 
atores globais do mercado de carbono mundial, o PCF do Banco Mundial, trouxe repercussões à Plantar (VENTURA \& ANDRADE, 2008).

Definitivamente, a empresa, seu processo de certificação e seu projeto de MDL foram colocados à prova para serem analisados por toda uma gama de atores sociais que compõem a governança ambiental global. Em nível global, as críticas dos movimentos e organizações socioambientalistas solicitando a revisão dos critérios de certificação ligados às plantações florestais parecem estar surtindo efeito. Tanto isso é verdade que se iniciou, em 2004, um processo global de revisão do princípio 10 da certificação FSC (FSC BRASIL, 2008b).

C) Descaso da empresa em relação às partes interessadas tanto no momento de obter a certificação FSC quanto para legitimar seu projeto de $M D L$

A ausência de contato entre a empresa e seus stakeholders, não apenas no que se refere à oitiva das partes interessadas, requisito básico obrigatório para um projeto de MDL, como também durante o processo de certificação FSC, que exige a realização de audiências públicas envolvendo esses atores sociais, seria mais uma contestação dos críticos ao Projeto em análise.

Ainda, afirmam os críticos existir uma série de conflitos como restrições impostas pela Plantar sobre a tradição de deixar o gado solto para pastar; contaminação de água com agrotóxicos, ocasionando a falta generalizada de água; poucos empregos oferecidos à comunidade local; geração de "clima de medo" na população, afirmando que o futuro da empresa e o da comunidade dependem da aprovação do Projeto; desvio de estrada tradicionalmente usada pela comunidade, sem a efetiva consulta (VENTURA \& ANDRADE, 2008). 
D) Críticas à gestão socioambiental da Plantar.

Os críticos ressaltam que a empresa possui um enorme passivo ambiental, ligado, especialmente, aos impactos negativos da eucaliptocultura e à utilização de carvão vegetal de madeira nativa, bem como um passivo trabalhista envolvendo a atividade carvoeira (condições e segurança do trabalho) e florestal.

Ainda destaca-se que o aumento da mecanização nas monoculturas diminui, a cada dia, o número de empregados (ACPO et al, 2003; AGB et al, 2003; SPUTITZ et al, 2004; WRM, 2006; OVERBEEK, 2007b). 


\section{CAPÍTULO IV - ANÁLISE DA MONOCULTURA DE SILVICULTURA}

\subsection{Dados preliminares sobre o eucalipto}

O eucalipto foi encontrado pelos ingleses na Austrália, por volta de 1788. É uma espécie arbórea pertencente à família das Mirtáceas e nativa desse país. A disseminação de sementes de eucalipto no mundo deu início no século XIX. Com mais de 700 espécies, no Brasil predominam as espécies de 20 a 60 metros de altura, mas há espécies de tamanho maior capazes de atingir 90 metros de altura.

O grande gênero Eucalyptus tem mais de 600 espécies, ocorrendo em zonas de baixa latitude até latitudes de $40^{\circ}$ sul. Cerca de 20 espécies são plantadas em larga escala no mundo (Lima, 1996), nas mais distintas condições ambientais, com amplas variações latitudinais, indo do clima temperado até o semiárido e com posicionamentos altimétricos muito variáveis.

No Brasil, seu cultivo em escala econômica deu-se a partir de 1904, através do trabalho do agrônomo silvicultor Edmundo Navarro de Andrade, para atender a demanda da Companhia Paulista de Estradas de Ferro (VALVERDE, 2007).

A exploração comercial no Brasil se deu no início do século XX, sendo inserida como monocultura dedicada a suprir a lenha para combustíveis das locomotivas e dormentes para trilhos das companhias ferroviárias.

A reformulação do Código Florestal Brasileiro, em 1965, o surgimento de órgãos como a Instituição Fiscal para Reflorestamento (FISET), em 1966 e o Instituto Brasileiro de Desenvolvimento Florestal (IBDF), em 1967, configuraram a base para uma nova política florestal no País (BINKOWISK \& FILIPP, 2009). 
Dessa forma, é na metade do século XX que o governo brasileiro intensifica a política de apoio fiscal para o reflorestamento financiando as grandes indústrias siderúrgicas e de papel e celulose.

O Governo Federal, em 2000, apresenta o Programa Nacional de Florestas (PNF), dois anos após lança o Programa de Plantio Comercial e Recuperação de Florestas (PROFLORA) e no mesmo ano introduz o Programa Nacional de Agricultura Familiar - PRONAF Florestal, ambos com o objetivo de dar oportunidade à linhas de crédito e custeio para os plantios florestais.

Nessa mesma linha existe o Financiamento Direto a Empreendimentos (FINEM), onde a instituição financiadora é o Banco Nacional de Desenvolvimento Econômico e Social (BNDES); entre 1991 e 2001, o BNDES investiu cerca de US\$ 435 milhões no setor de base florestal. Outro financiador é o Banco do Brasil que lançou em 2005 o "BB Florestal", com o objetivo de criar novas oportunidades de investimentos florestais de longo prazo (BINKOWISK \& FILIPP, 2009).

Por seu crescimento rápido, aceita cortes contínuos e fornece matéria-prima para diversos fins, tendo, por conseguinte, se tornado uma das principais espécies para o cultivo de madeira, visando o mercado consumidor.

No Brasil, o período de crescimento vegetal do eucalipto é de 7 anos, enquanto que em países de clima temperado a arbórea tem um ciclo de vida de 50 anos (DALCOMUNI,1990). Entretanto, por volta do terceiro a quinto ano, já tolera um primeiro corte do tronco para o aproveitamento da madeira, em seguida retornam a vegetar.

Mais de 70\%, de todo eucalipto plantado no Brasil é utilizado na produção de papel e transformado em carvão vegetal, esse carvão é utilizado principalmente em siderúrgicas, no lugar do carvão mineral (Figura 23). 
O Estado brasileiro atualmente com a maior área plantada dessa espécie é o Estado de Minas Gerais.

A Sociedade Brasileira de Silvicultura (SBS, 2002), retrata que a área plantada de eucalipto no Brasil, correspondia a 1.77 milhões há, no ano de 2002. Em 34 anos, a área plantada de eucalipto aumentou em quase sete vezes, em relação a área plantada em 1966. (Figura 24).

Figura 23: Brasil - Destino do eucalipto plantado

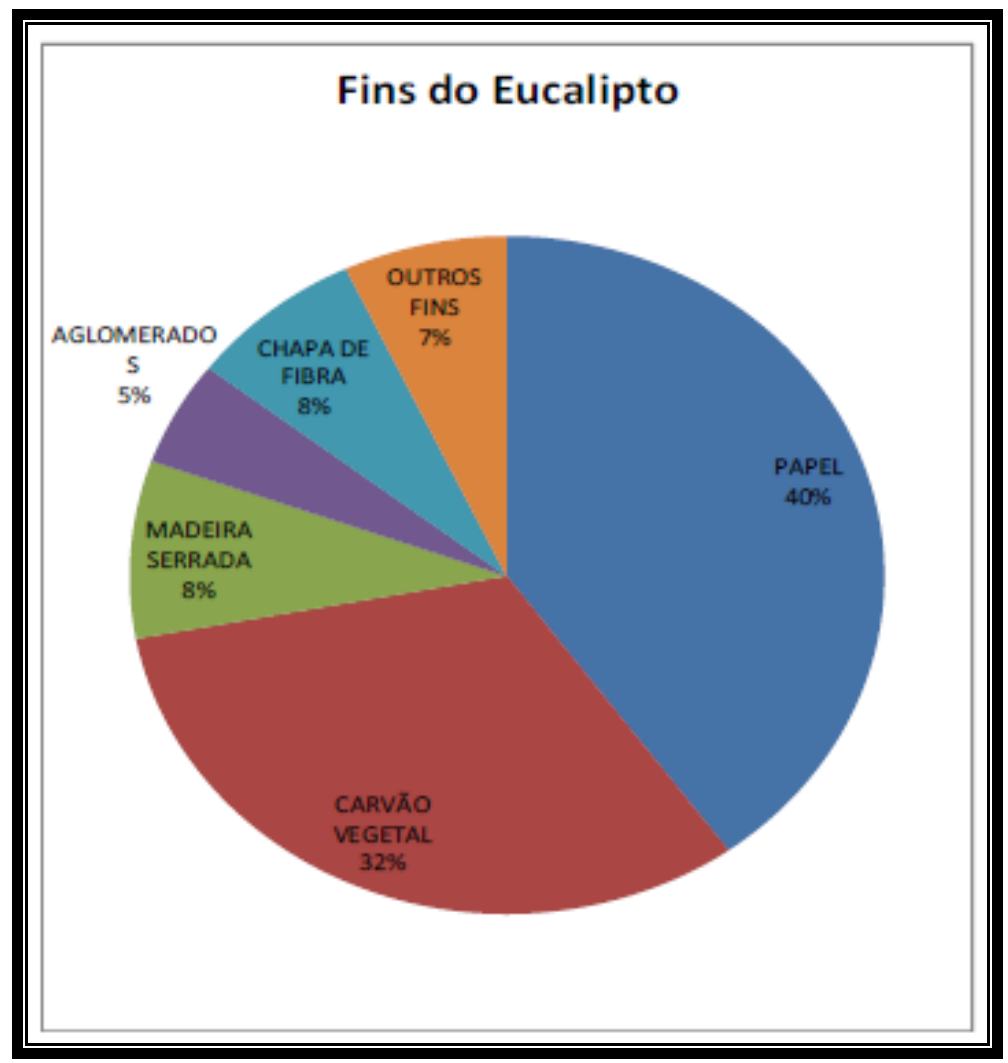

Fonte: SBS, 2007

Em 2009, a área total de florestas de eucalipto plantadas, atingiu 4.576.000 ha, como mostrado (Figura 24). Como se pode observar (Figura 25), o aumento da plantação de eucalipto, teve um ritmo menos acelerado entre os anos de 2008 e 2009, em relação aos anos anteriores, 
haja vista a crise financeira internacional, que afetou a economia mundial, reduzindo expressivamente a demanda dos mercados compradores das cadeias produtivas baseadas em madeiras de eucalipto (SBS, 2010).

Figura 24: Área plantada de eucalipto no Brasil até 2002

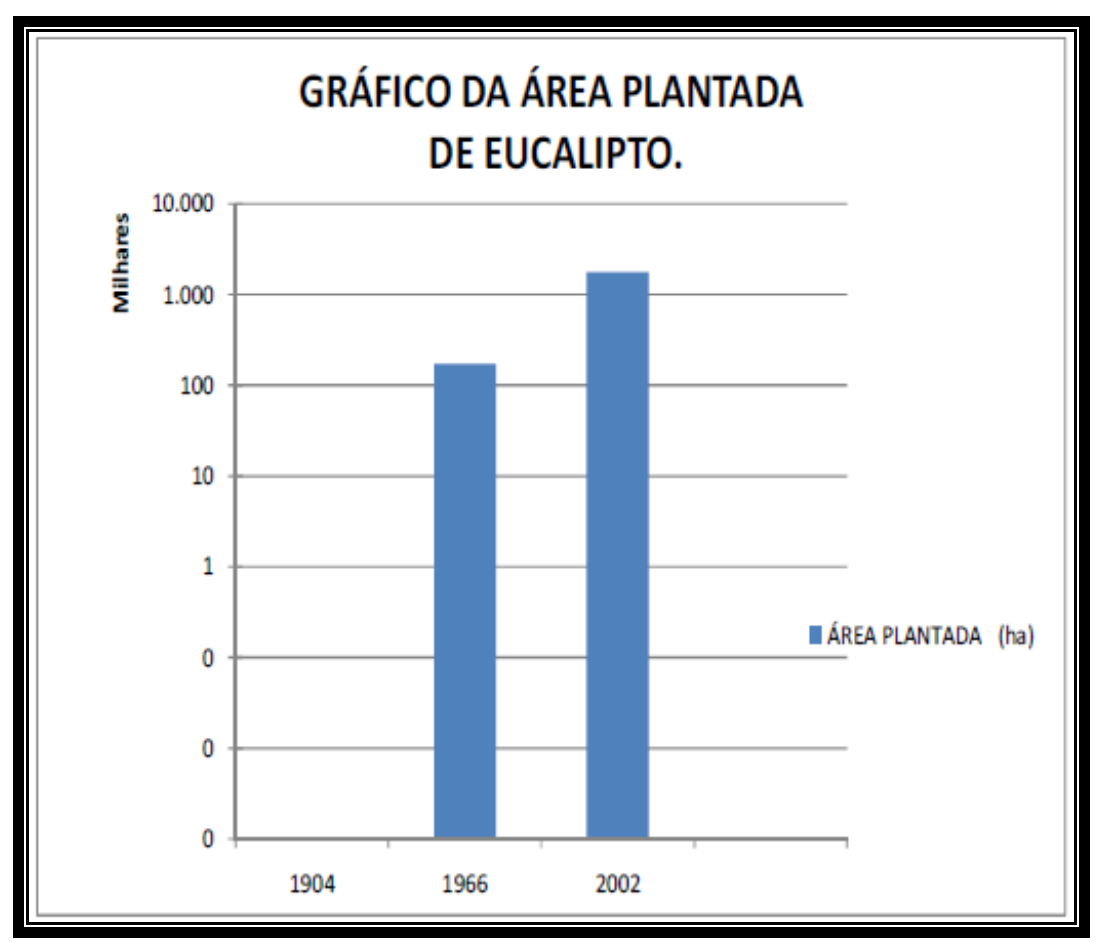

Fonte: SBS, 2002 
Figura 25: Área plantada de eucalipto no Brasil

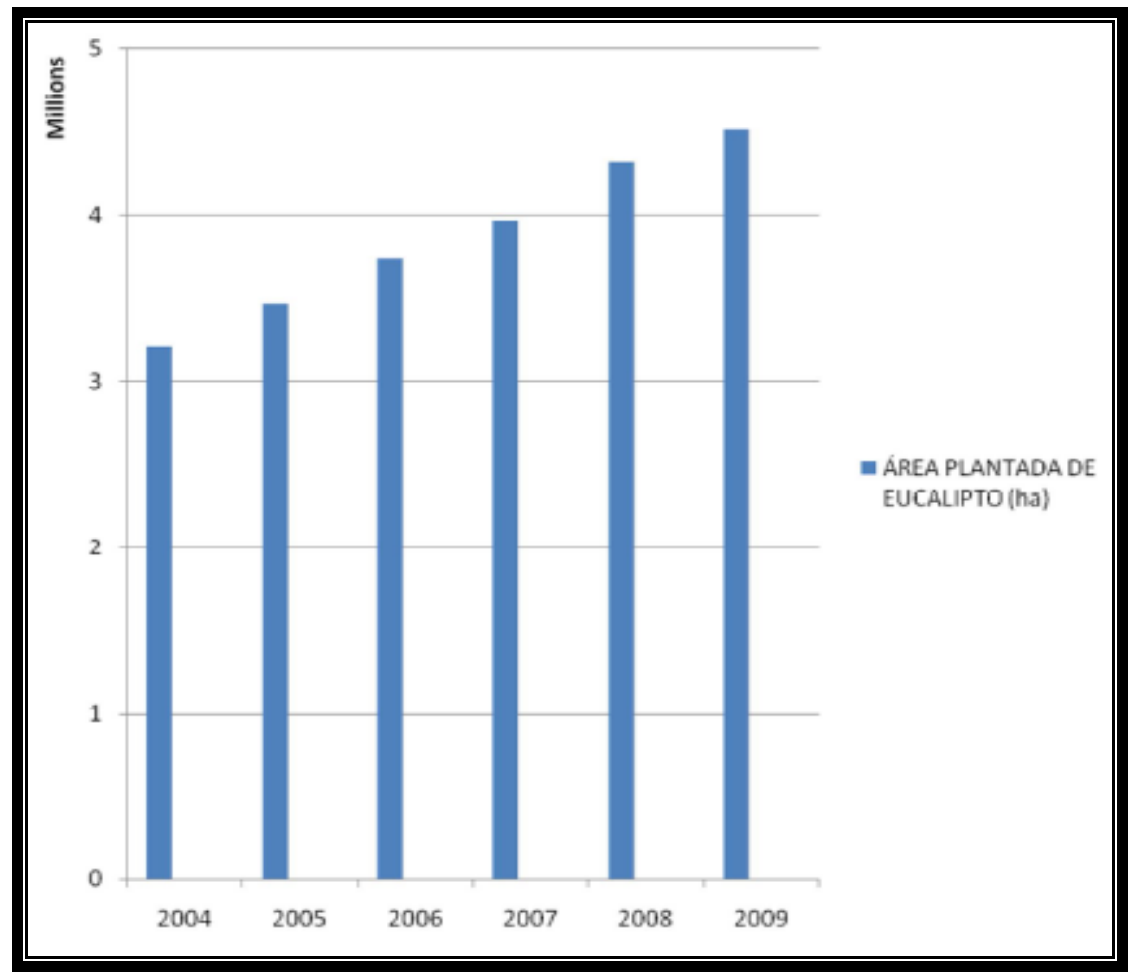

Fonte: SBS, 2009

O Brasil é um dos principais produtores de eucalipto do mundo (SBS, 2009) (Tabela $10)$.

Tabela 10: Mundo - Maiores produtores de eucalipto.

\begin{tabular}{|c|c|}
\hline PAÍS & EUCALÍPTO* (1000 há) \\
\hline INDIA & 9200 \\
\hline BRASIL & 4500 \\
\hline PORTUGAL & 1000 \\
\hline ÁFRICA DO SUL & 900 \\
\hline PERÚ & 680 \\
\hline VIETNÃ & 650 \\
\hline TAILÂNDIA & 640 \\
\hline CHILE & 540 \\
\hline INDONÉSIA & 330 \\
\hline VENEZUELA & 90 \\
\hline
\end{tabular}

Fonte: SBS, 2009 
A taxa de crescimento das plantações de eucalipto nos últimos cinco anos foi de $30 \%$ no Brasil. (Tabela 11)

Tabela 11: Taxa de crescimento das plantações de eucalipto nos últimos cinco anos

\begin{tabular}{|c|c|c|c|c|c|}
\hline \multirow[b]{2}{*}{ UF } & \multicolumn{5}{|c|}{ Área de eucalipto plantada (ha) } \\
\hline & 2005 & 2006 & 2007 & 2008 & 2009 \\
\hline MG & 1.119 .259 & 1.181 .429 & 1.218 .212 & 1.278 .210 & 1.292 .150 \\
\hline SP & 798.522 & 915.841 & 911.908 & 1.001 .080 & 1.029 .620 \\
\hline PR & 114.996 & 121.908 & 123.078 & 142.430 & 157.920 \\
\hline BA & 527.386 & 540.172 & 550.127 & 587.610 & 628.440 \\
\hline SC & 61.166 & 70.341 & 74.008 & 77.440 & 108.140 \\
\hline RS & 179.690 & 184.245 & 222.245 & 277.320 & 271.980 \\
\hline MS & 113.432 & 119.319 & 207.687 & 265.250 & 290.890 \\
\hline ES & 204.035 & 207.800 & 208.819 & 210.410 & 204.570 \\
\hline PA & 106.033 & 115.806 & 126.286 & 136.290 & 139.720 \\
\hline MA & 60.745 & 93.285 & 106.802 & 111.120 & 137.360 \\
\hline GO & 47.542 & 49.637 & 51.279 & 56.880 & 57.940 \\
\hline $\mathbf{A P}$ & 62.087 & 58.473 & 58.874 & 63.310 & 62.880 \\
\hline MT & 42.417 & 46.146 & 57.151 & 58.580 & 61.510 \\
\hline TO & 2.124 & 13.901 & 21.655 & 31.920 & 44.310 \\
\hline OUTROS & 25.285 & 27.491 & 31.588 & 27.580 & 28.280 \\
\hline TOTAL & 3.464 .719 & 3.745 .794 & 3.969 .719 & 4.325 .430 & 4.515 .710 \\
\hline
\end{tabular}

Fonte: SBS, 2009 
Entretanto, nem todo o eucalipto plantado é revertido em créditos de carbono, somente são revertidos os destinados ao setor energético (32\%). Segundo a SBS, até o ano de 2015 haverá um crescimento de $1,4 \%$ por ano, na transformação do eucalipto em carvão vegetal (Figura 26) (SBS, 2010).

A Figura 26, mostra uma projeção de valores gerados para cada ano, através dos créditos de carbono, oriundos da área que será cultivada até 2015. Esses valores foram obtidos da seguinte forma, cada crédito de carbono gerado, pode ser vendido por cerca de 20 euros, logo foi calculado quantos créditos de carbono geraria a área de eucalipto destinado ao carvão vegetal, e multiplicado por 20 euros (SBS, 2010).

Dessa forma, é nítido, que a monocultura de silvicultura no país faz parte das principais culturas do agronegócio brasileiro, sobretudo para fornecimento de matérias primas para o setor siderúrgico e de papel e celulose.

Figura 26: Projeção da área de eucalipto destinada à produção de carvão vegetal.

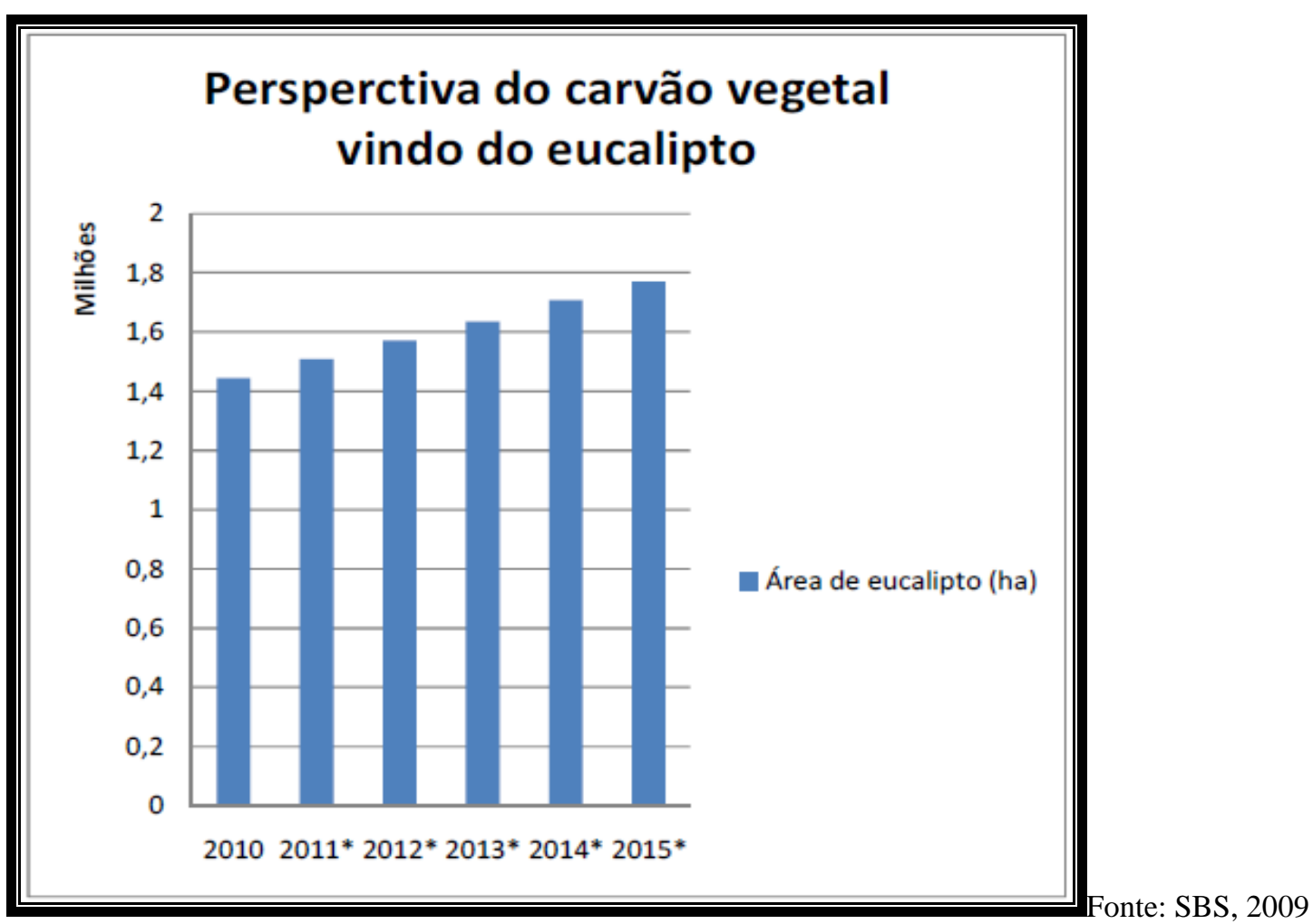


Figura 27: Projeção da venda de créditos de carbono originado da área de eucalipto destinada à produção de carvão vegetal.

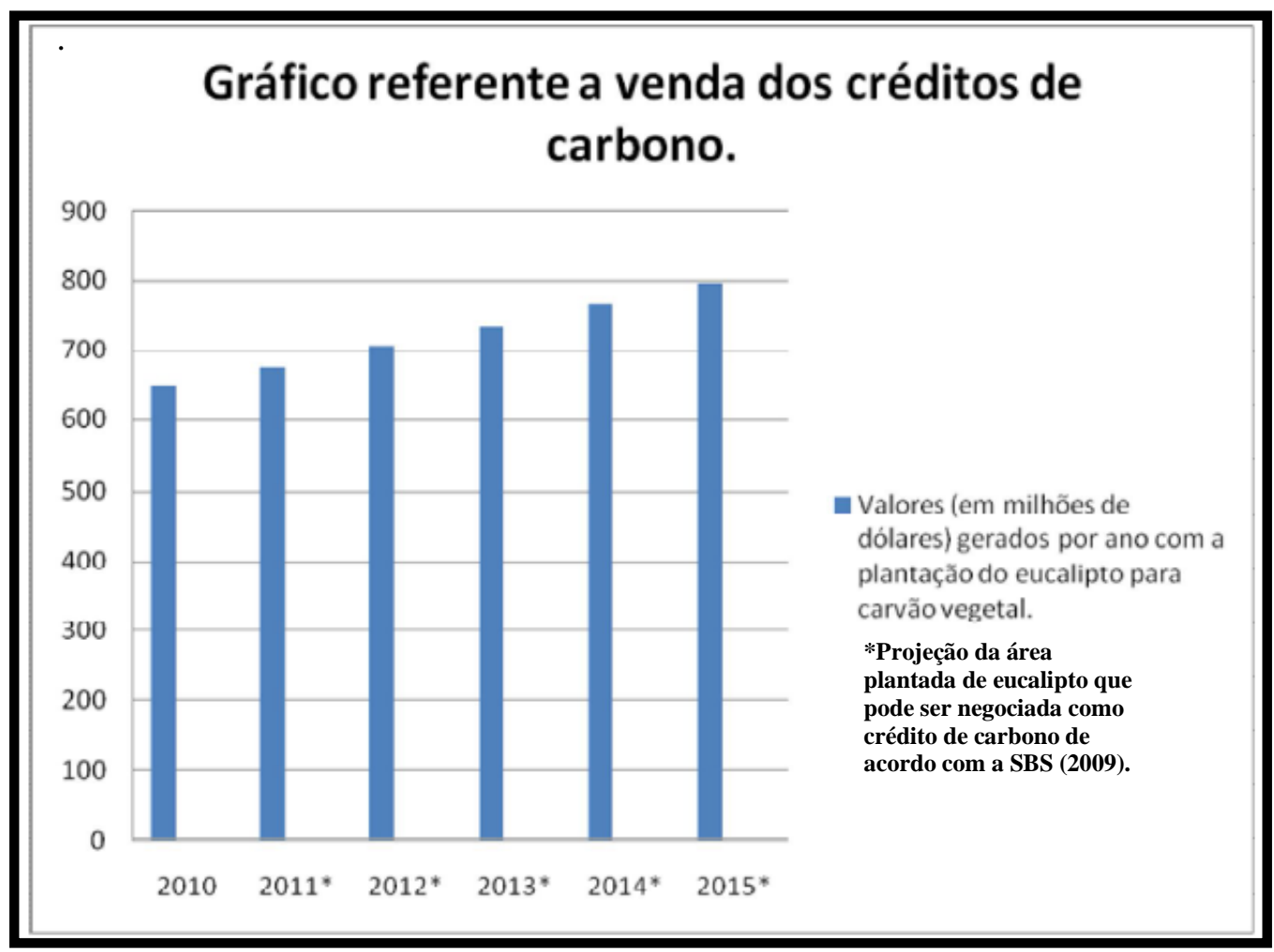

Fonte: SBS, 2009

4.2 O panorama atual da Silvicultura no Brasil - O eucalipto é a resolução dos problemas ambientais?

Nessa parte da pesquisa foi realizada uma análise em decorrência da utilização da monocultura da silvicultura no Brasil. Para tanto, levantou-se dados específicos sobre alguns setores em que o eucalipto figura como matéria prima, bem como o comportamento geral do mercado.

Dessa forma, o que se busca é demonstrar uma análise crítica sobre a utilização da monocultura de silvicultura no Brasil e os possíveis interesses na sua implantação, expansão e manutenção.

Em 2010, a área ocupada por plantios florestais de Eucalyptus e Pinus no Brasil totalizou 6.510 .693 ha, sendo $73 \%$ correspondente à área de plantios de Eucalyptus e $27 \%$ a 
plantios de Pinus. No período 2005-2010, o crescimento acumulado foi de 23\%, ou seja, 3,5\% ao ano (ABRAF, 2011) (Figura 28).

Importante se destacar que o crescimento dos plantios florestais em 2010 foi considerado pelo setor de papel e celulose e siderúrgico como modesto, se comparado ao quinquênio anterior, em decorrência da crise americana e global de 2008.

A maior concentração de plantios florestais (Eucalyptus e Pinus) ocorre nas regiões sul e sudeste do país $(75,2 \%)$, onde também estão localizadas as principais unidades industriais dos segmentos de celulose, papel, painéis de madeira industrializada e siderurgia a carvão vegetal. (ABRAF, 2011).

Minas Gerais, São Paulo, Paraná, Bahia, Santa Catarina, Rio Grande do Sul e Mato Grosso do Sul destacaram-se no cenário nacional como os estados detentores de $88 \%$ da área total de plantios florestais (ABRAF, 2011) (Figura 29).

Figura 28: Área de plantio de silvicultura no Brasil.

\section{TOTAL (EUCALYPTUS + PINUS)}

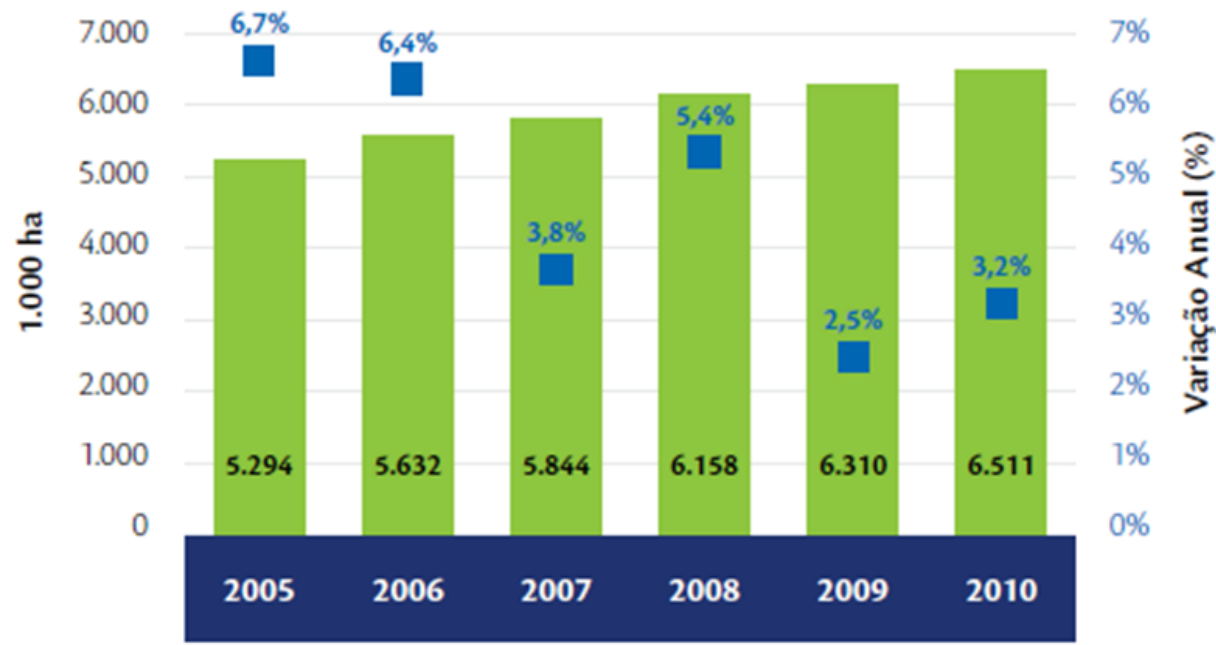

Fonte: ABRAF, 2011 
No que tange ao histórico da atividade de silvicultura no país pode ser destacado três períodos bem diferenciados. O primeiro (1960-1980) foi o de introdução e fundamentalmente estruturador do setor florestal, resultado de uma política governamental de concessão de incentivos fiscais para formação de plantios florestais.

O segundo momento (1980 - 2000) foi o amadurecimento profissional do setor florestal. Momento em que houve a maturação das primeiras iniciativas do setor que foram impulsionadas pelos incentivos governamentais realizados anteriormente.

No terceiro período (2000-2010) ocorreu a consolidação do setor florestal no Brasil, bem como a ampliação das áreas de plantios e de processos de desenvolvimento tecnológico.

No Brasil, 37,5\% de toda a madeira produzida é utilizada para a produção de celulose. A produção de serrados, painéis e compensados consome $15,8 \%, 7,8 \%$ e 3,5\%, respectivamente. O restante $(35,4 \%)$ é destinado à produção de lenha, carvão vegetal e outros produtos florestais (ABRAF, 2011).

Percebe-se, portanto, uma alta demanda de madeira pelos setores de papel e celulose, bem como carvão vegetal que juntos correspondem por mais de $70 \%$ da utilização de madeira produzida.

O gráfico, a seguir, demonstra esquematicamente, a utilização de madeira no Brasil pelos diversos setores industriais (Figura 30). Os produtos como lenha, carvão vegetal e painéis de madeira industrializada, concentram-se no mercado interno enquanto os demais produtos destinam-se ao mercado externo.

Boa parte dos produtos secundários (móveis, papel, pisos, molduras, ferro e aço, etc.) também é exportada, demonstrando, assim, a importância do cenário internacional para o setor florestal brasileiro. 
Figura 29: Percentual da área da silvicultura por Estados da federação - Brasil.

\begin{tabular}{|c|c|}
\hline UF & Total (ba) \\
\hline MC & 1536310 \\
\hline$\$$ & $120<x$ \\
\hline $\mathrm{Pa}$ & 8.7.231 \\
\hline $\mathrm{BA}$ & $\operatorname{csan} 4$ \\
\hline$s c$ & (4.7.9) \\
\hline as & แ.ตท \\
\hline MS & 322042 \\
\hline ES & 207.41 \\
\hline $\mathrm{MA}$ & 16arse \\
\hline $\mathrm{Ma}$ & 15นตอ3 \\
\hline$\infty 0$ & 7060 \\
\hline$A$ & 22334 \\
\hline$M T$ & 61950 \\
\hline to & $42 m 2$ \\
\hline a & 37025 \\
\hline Qutes & 4050 \\
\hline Tocal & 6.510 .603 \\
\hline
\end{tabular}

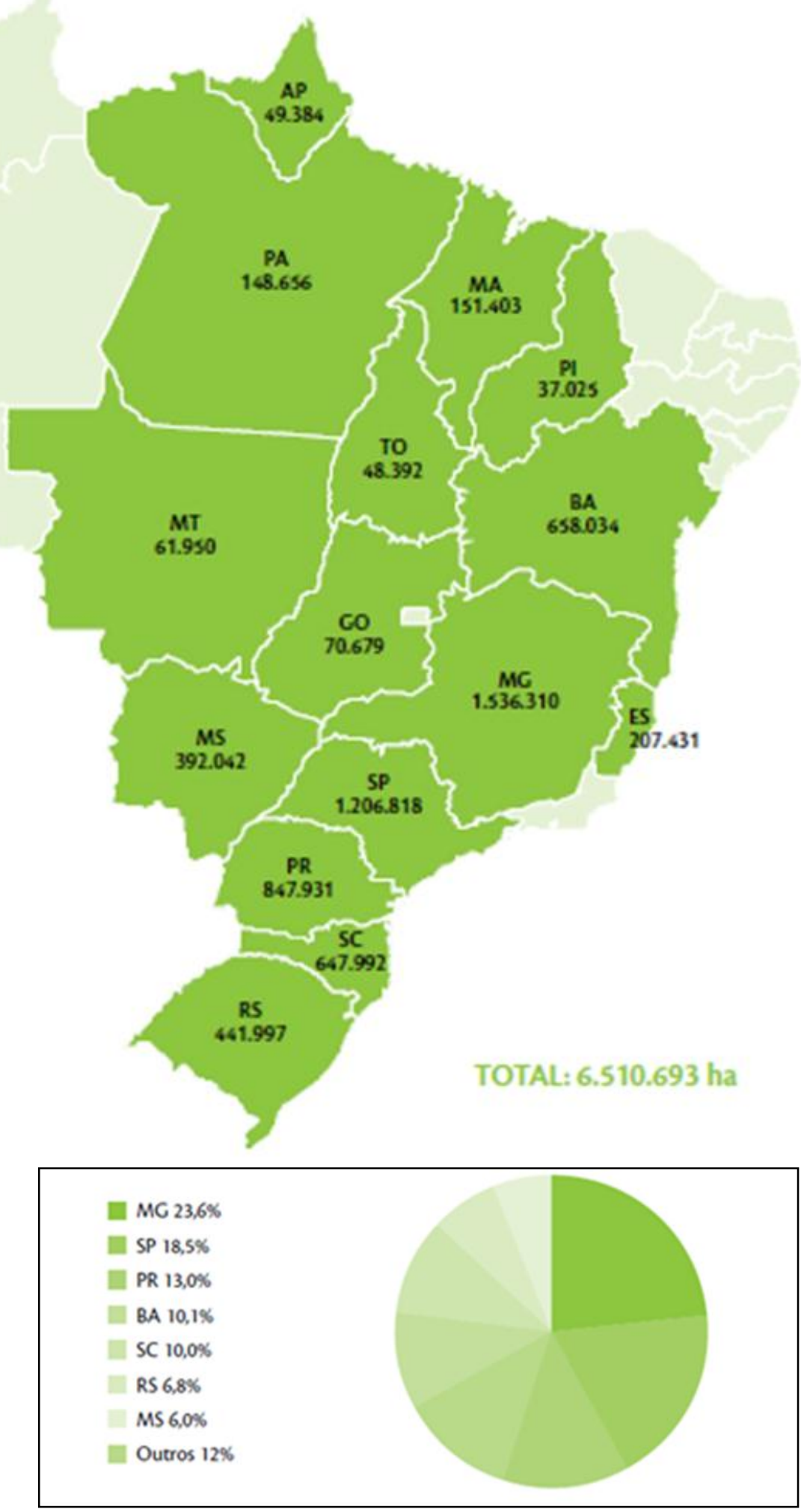

Fonte: ABRAF, 2011 
Figura 30: Setores econômicos atendidos pela produção da silvicultura no Brasil.

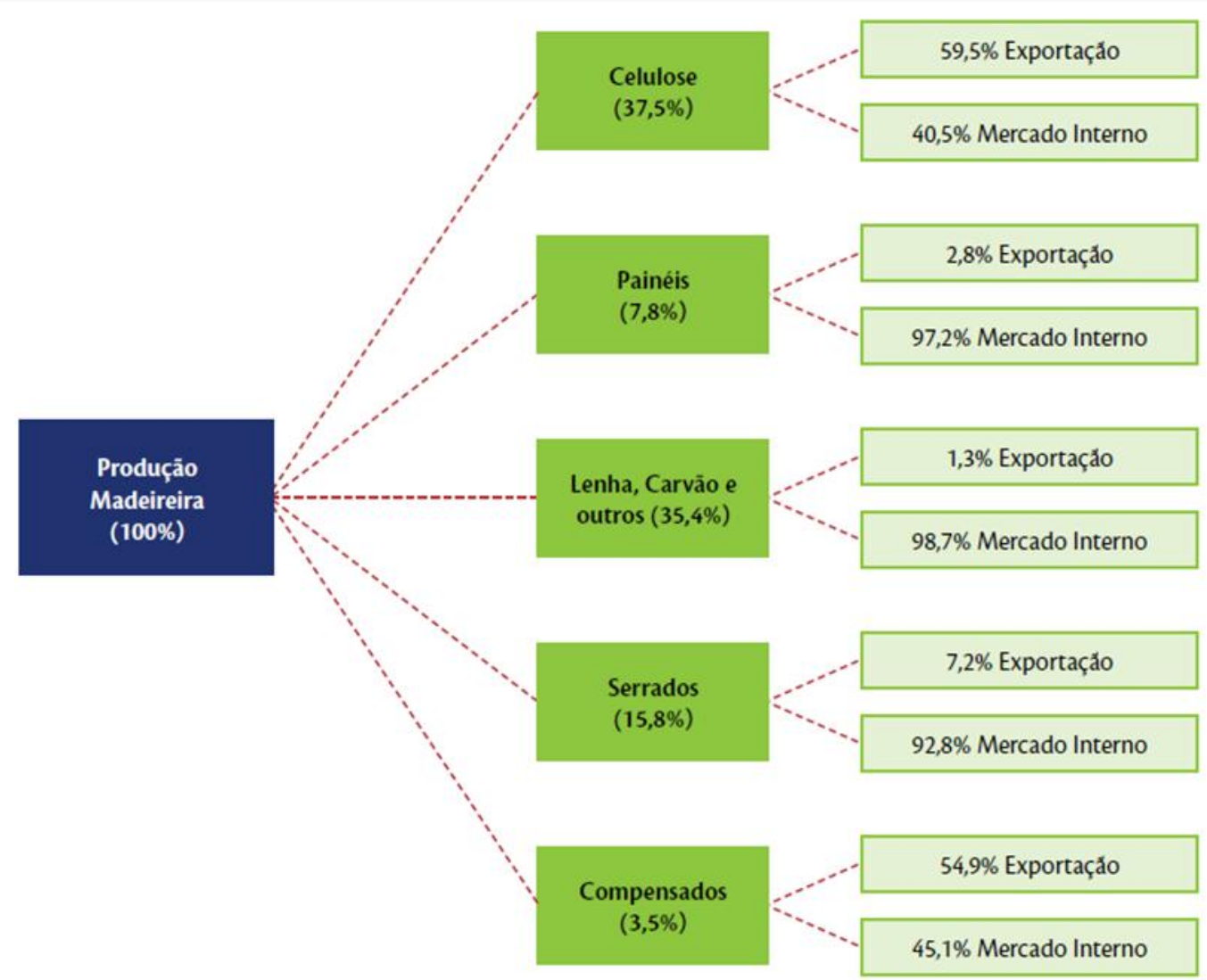

Fonte: ABRAF, 2011

Para que se possa realizar uma análise mais pormenorizada dos aspectos da monocultura de silvicultura de eucalipto no Brasil, se faz necessário o balanço de alguns resultados de alguns setores que envolvem essa atividade no país.

Dessa maneira destacam-se os seguintes setores:

- Papel e Celulose

A produção brasileira de celulose de fibra curta (Eucalyptus) surge com o intuito de substituição de importação ao produto importado da Europa e dos Estados Unidos. Entretanto, diante do alto poder competitivo, superior ao de países líderes de produção, houve um aumento vertiginoso da produção do gênero no país.

Apesar da análise conjuntural não ser a ideal, uma vez que o setor, como muitos outros da economia, foi atingido pela crise americana de proporções mundiais, os resultados do setor 
de celulose e papel em 2010 indicaram avanços significativos tanto na consolidação do Brasil no mercado externo quanto no crescimento doméstico.

A produção de celulose nacional totalizou 14,1 milhões de toneladas em 2010, crescimento de 4,5\% em relação ao ano anterior. O patamar atual de produção coloca o Brasil no $4^{\circ}$ lugar do ranking mundial dos produtores de celulose (ABRAF, 2011).

No mesmo período, o consumo interno atingiu 6,1 milhões de toneladas, 9,1\% superior ao registrado em 2009. No mercado externo Europa e China continuam sendo os dois maiores destinos da produção brasileira (ABRAF, 2011).

De acordo com a Associação Brasileira de Celulose e Papel, as empresas brasileiras produziram 9,8 milhões de toneladas de papel em 2010. Desse total, quase metade correspondeu a papéis para imprimir e escrever, ao passo que a produção de papel para embalagens totalizou 4,8 milhões de toneladas (BRACELPA, 2011).

Ainda, há uma previsão em investimentos na ordem de US\$ 20 bilhões nos próximos dez anos, visando à ampliação da base florestal e ao aumento da produção de celulose e papel para atender à crescente demanda interna e à expansão dos mercados externos emergentes (BRACELPA, 2011).

- Siderurgia a Carvão Vegetal

Segundo estimativas do Instituto Aço Brasil o país possui um parque produtor de aço composto por 28 (vinte e oito) usinas, sendo que 13 (treze) integradas (a partir do minério de ferro) e 15(quinze) semi-integradas (a partir do processo de ferro gusa com a sucata), administradas por 10 (dez) grupos empresariais, sendo o $7^{\circ}$ maior exportador de aço do mundo, negócio capaz de movimentar U\$ 337 milhões por ano (IABR 2011) (Tabela 12). 
Tabela 12: Mercado de Aço - Brasil

\section{DADOS DE MERCADO - 2010}

Parque produtor de aço: 28 usinas, sendo que 13 integradas (a partir do minério de ferro) e 15 semiintegradas (a partir do processo de ferro gusa com a sucata), administradas por 10 grupos empresariais.

Capacidade instalada: 44,6 milhões de t/ano de aço bruto

Produção Aço Bruto: 32,9 milhões de t

Produtos siderúrgicos: 31,8 milhões de t

Produtos siderúrgicos: 31,8 milhões de $t$

Consumo aparente: 26,1 milhões de $t$

Número de colaboradores: 142.226

Saldo comercial: US\$337 milhões - 1,7\% do saldo comercial do país

$15^{\circ}$ Exportador mundial de aço (exportações diretas)

$7^{\circ}$ Maior exportador líquido de aço (exp - imp): 3,1 milhões de $t$

Exporta para mais de 100 países

Exportações indiretas (aço contido em bens): 2,7 milhões de $t$

Consumo per capita de aço no Brasil: 152 quilos de aço bruto/habitante

Principais setores consumidores de aço: Construção Civil; Automotivo; Bens de capital, Máquinas e Equipamentos (incluindo Agrícolas); Utilidades Domésticas e Comerciais.

Fonte: açobrasil.org.br 2010.

Tais números se referem ao ano base de 2010, e mostram uma defasagem de mercado em relação a anos anteriores por conta da crise de 2008 que afetou de forma brutal o setor em análise. No Brasil a produção anual foi de apenas $1 / 3$ da capacidade instalada e somente $56,0 \%$ dos fornos funcionaram. No polo de Carajás (Maranhão-Pará), maior exportador nacional, apenas $30 \%$ dos fornos foram ligados e a produção atingiu 59,0\% da capacidade instalada. Em Minas Gerais, maior produtor nacional, apenas metade dos fornos estavam desligados e a produção atingiu 41,0\% da capacidade (ABRAF, 2011).

O maior comprador continuou sendo os Estados Unidos. A China, segundo maior país importador, reduziu as compras do gusa nacional em 78,0\%, adquirindo apenas 261 mil toneladas contra 1,2 milhão em 2009 (ABRAF,2011). 
Apesar dos números do setor os problemas ambientais associados à produção de ferro e aço são o consumo de água, a contaminação dos corpos d'água pelos efluentes industriais e a poluição atmosférica.

Grandes volumes de água usados pelas usinas se devem ao resfriamento dos equipamentos. Inúmeros são os efluentes e resíduos sólidos provenientes do processo de obtenção do aço pelas usinas, bem como o lançamento na atmosfera de uma quantidade de poluentes como monóxido de carbono (CO), óxidos de nitrogênio (NOx), óxidos de enxofre (SOx), gás sulfídrico $\left(\mathrm{H}_{2} \mathrm{~S}\right)$, dióxido de carbono $\left(\mathrm{CO}_{2}\right)$, metano $\left(\mathrm{CH}_{4}\right)$, etano $\left(\mathrm{C}_{2} \mathrm{H}_{6}\right)$, material particulado e diferentes hidrocarbonetos orgânicos, como o benzeno. Cabe lembrar que o $\mathrm{CO}_{2} \mathrm{e}$ $\mathrm{CH}_{4}$ contribuem para o aumento da quantidade de carbono na atmosfera e, consequentemente, para as mudanças climáticas.

- Carvão vegetal

O Brasil é o maior produtor mundial de carvão vegetal. Os principais consumidores são os setores de ferro-gusa, aço e ferros-liga e, em menor escala, o comércio e o consumidor residencial. Atualmente, aproximadamente $55,0 \%$ da produção brasileira de carvão vegetal ainda é proveniente de florestas nativas (ABRAF,2011).

O ferro-gusa é um produto intermediário pelo qual passa praticamente todo o ferro utilizado na produção do aço, obtido a partir da fusão de minério de ferro em altos-fornos, onde carvão vegetal ou carvão vegetal (coque) são utilizados como fontes de energia e agentes de redução.

Para a economia florestal, a gama de empresas mais relevante no quesito consumo de carvão vegetal faz referência aos produtores independentes de ferro-gusa, os quais são fornecedores de matéria-prima para a indústria do aço. Em 2010, foram produzidos 11,6 milhões de $\mathrm{m}^{3}$ de carvão vegetal a partir de florestas plantadas, dos quais $66,2 \%$ foram consumidos pelos "guseiros" independentes (ABRAF,2011). 
No sudeste do Brasil a produção de carvão vegetal vem sendo substituída por monoculturas de produção de eucalipto tendo em vista a diminuição dos custos com a obtenção de madeira que são retiradas de locais cada vez mais distantes, bem como a pressão de organismos nacionais e internacionais ambientais.

Apesar dos pontos positivos a monocultura de eucalipto é altamente favorecedora de uma concentração fundiária, em detrimento da utilização da terra pelas comunidades locais, exploração da mão de obra, bem como a contaminação do solo pelo uso intensivo de agrotóxicos e redução da biodiversidade.

Em outros termos, o eucalipto é um dos grandes responsáveis pelo fracasso da Revolução Verde concebida nas décadas de 1960 e 1970 . Na verdade quando se refere ao termo fracasso, tem se a análise do ponto de vista social e humano, pois do ponto de vista do capital, ou do agronegócio ele é sem dúvida, uma das culturas de destaque no país.

Na região da Amazônia Oriental, por exemplo, a siderurgia favoreceu a concentração fundiária através de dois mecanismos principais. Em primeiro lugar, existe a concentração direta, uma vez que muitas empresas na região acabam por adquirir largas extensões de terra para a instalação de monoculturas. Denúncias de movimentos sociais e casos relatados na mídia indicam que muitas dessas aquisições são feitas através de grilagem e violência contra posseiros. A segunda contribuição se dá de forma indireta, pois como as carvoarias compram madeira de terceiros, elas baratearam o custo da limpeza dos terrenos, favorecendo a expansão das pastagens (MONTEIRO, 1994).

4.3 O mercado de florestas no Brasil e sua sustentabilidade

O mercado de florestas no Brasil é altamente atrativo do ponto de vista econômico e gera um capital significativo para o PIB nacional. Chama-se a atenção para a concentração 
desse mercado em zonas cuja a economia pode ter uma escala maior devido a infraestrutura de transporte e consumo desse produto.

As empresas têm três opções básicas para organizar o abastecimento de matériasprimas: produção própria (verticalizada); produção mediante contrato com terceiros (integração) ou aquisição no mercado. (SCHEJTMAN,1998)

Com relação ao uso da madeira destacam-se a existência de quatro formas distintas, que caracterizam os seguintes tipos de indústria (ABRAF,2011):

“- Indústria primária: realiza apenas um processamento sobre a matéria-prima (madeira), transformando-a em madeira laminada, serrada e imunizada, além de carvão vegetal e cavaco.

- Indústria secundária: utiliza produtos obtidos do desdobramento da matéria-prima (processo primário) para obter o produto final (processo secundário), destinado ao consumidor final ou outras indústrias do setor terciário.

- Indústria terciária: gera inúmeros produtos de maior valor agregado, altamente especializados, para atender às diversas necessidades do consumidor final.

- Indústria integrada (verticalizada): possui dois ou mais níveis de agregação industrial (primária, secundária elou terciária) na fabricação de seu produto final, como as indústrias de celulose e papel integradas, que compreendem uma fase primária de produção de cavaco, a fase secundária de produção da celulose, e a fase terciária de produção do papel. Já as indústrias de painéis de madeira industrializada possuem a etapa primária de produção de cavaco, e a secundária de transformação em painéis de MDP, MDF, HDF, OSB, etc."

As dimensões continentais do Brasil favoreceram o desenvolvimento do parque industrial de base florestal ao longo de todo o seu território. Entretanto, as empresas tendem a se concentrar em regiões onde aspectos regionais e logísticos favorecem a geração de economias 
de escala. As regiões onde ocorrem as concentrações de empresas ligadas ao setor de base florestal (clusters), cuja principal fonte de matéria-prima é o Eucalyptus (ABRAF, 2011).

Vistos os números e o comportamento geral do mercado de silvicultura em alguns de seus principais setores, irá se realizar, nesse momento, a interpretação dessas informações anteriormente ventiladas.

Em primeiro momento, deve-se ter claro que os números mostram uma parcela da realidade da qual se quer tratar e devem ser analisados, com cautela e reflexão, e não como expressão absoluta da verdade.

Aliás, são indicadores de fenômenos e não a transcrição em si desses. Portanto, importante se frisar que fazem parte de uma pequena parcela da realidade. Nesse sentido, como ressaltado anteriormente nesse trabalho, se faz necessário uma reflexão mais sistêmica dos fenômenos e a compreensão de que há vários elementos interligados.

Os números apresentados são basicamente de cunho econômico e chamam a atenção para o desenvolvimento do mercado da monocultura de silvicultura no Brasil. Dessa maneira devemos entender que o "desenvolvimento" retratado por esses indicadores estão inseridos na concepção capitalista de desenvolvimento, ou seja, a obtenção de lucros.

Entretanto, desenvolvimento não é uma palavra de acepção única e comporta diversas interpretações pelos diferentes agentes que atuam na questão da expansão da produção de eucalipto. Ou seja, existem concepções e práticas muito ambíguas sobre a ideia de desenvolvimento.

Cabe ressaltar qual é a verdadeira acepção para o desenvolvimento em questão? Desenvolver-se significa apenas o caráter econômico de geração de riqueza?

O desenvolvimento sustentável tem como uma das premissas fundamentais o reconhecimento da insustentabilidade ou inadequação econômica, social e ambiental do padrão de desenvolvimento das sociedades contemporâneas. (SCHMITT, 1995) 
Para (BINKOWISK \& FILIPP, 2009) existe um cenário complexo, onde se visualiza diferentes forças atuando, porém, ao pensarmos especificamente sobre a questão da expansão da produção de eucalipto, percebemos que uma das principais disputas refere-se à tentativa de impor diferentes concepções e práticas sobre a ideia de desenvolvimento.

Por meio da criação de políticas públicas para incentivar os cultivos da silvicultura, o Estado tem como centro de seu discurso desenvolvimento econômico, traduzidos em geração de empregos, arrecadação de impostos, melhoria de infra-estrutura regional e local (BINKOWISK \& FILIPP, 2009).

Mas é diante desse ponto exclusivo de análise que a comunidade quase sempre é deixada para último plano. Na verdade, ao analisar a ótica do desenvolvimento o Estado vislumbra na iniciativa privada a possibilidade de implantação de uma estrutura que não teve ou não tem condições de apresentar a população, quer muitas vezes pelos recursos necessários para o projeto, quer outras, como em muitas vezes, no caso brasileiro, por falta de vontade política ou incompetência gerencial.

Destaca-se que na situação descrita anteriormente o Estado não é o detentor de uma política pública de longo prazo, mas sim de um plano de governo, que atende a interesses momentâneos de determinados estamentos políticos e que, infelizmente, são colocados acima dos verdadeiros interesses coletivos.

$\mathrm{Na}$ realidade essa situação é constantemente reiterada, ou seja, se institucionaliza desequilíbrios ambientais, em nome de uma política "desenvolvimentista" que trará benefícios para o ciclo econômico local.

No caso, as atividades florestais só seriam consideradas sustentáveis, se realmente assegurassem as garantias difusas sociais, ambientais, econômicas e culturais do desenvolvimento, o que é a transcrição da noção de sustentabilidade dos sistemas, ou do desenvolvimento sustentável do planeta. 
Acontece que em muitos casos, o que tais medidas estatais refletem é a pura fórmula do sistema que autoriza institucionalmente a concentração fundiária em uma monocultura voltada para os anseios do capital.

Repete-se algo que historicamente já se conhece. O Brasil passou por grandes ciclos econômicos como o da cana-de-açúcar, baseados no sistema de plantation, em que existia uma concentração fundiária e de renda, nas mãos dos senhores de engenho, monocultura agrícola, mão-de-obra escrava e uma economia baseada na exportação.

Evidente que o Brasil superou a escravidão negra, mas que essa deixou sequelas até os dias atuais em todos os setores de nossa sociedade, e que tecnicamente esta não existe mais, entretanto, devido ao atendimento aos anseios do capital, muitos trabalhadores desse tipo de culturas são explorados e considerados em situação análogas a de escravo.

A concentração fundiária no país ainda é uma triste realidade e que o pilar sustentador desta são monoculturas agrícolas como a do eucalipto que visam a atender exclusivamente os anseios do mercado, em detrimento das condições sociais da grande parcela da população brasileira dessa forma do ponto de vista prático pouco se alterou.

Dessa maneira as comunidades locais devem ser livres para optarem, da melhor forma possível e articulada, por seus processos de desenvolvimento autônomos. Portanto, o Estado deve levar em consideração os valores culturais, sociais e ambientais dessa comunidade em questão.

Cada localidade, comunidade, municipalidade, sub-região, região poderá e deverá optar por um processo de desenvolvimento que respeite seus valores e recursos específicos e melhor participação do processo mundial de desenvolvimento (BINKOWISK \& FILIPP, 2009).

Para que as decisões do Estado possam ser efetivadas e, portanto, realizar seu objetivo maior de manutenção do sistema, é necessário que ele se proteja sob a capa da neutralidade, de mediador dos interesses conflitantes, com uma posição "acima" das classes (NETO, 1995). 
Por fim, o Estado deve ser mediador dos conflitos existentes entre os diversos setores sociais, mas nunca incentivador de medidas que visem a acumulação do capital nas mãos de poucos, bem como a exclusão social.

4.4 Os problemas ambientais decorrentes da utilização da monocultura de eucalipto.

De maneira geral as empresas que fomentam o setor da monocultura de eucalipto no Brasil advogam o emprego de determinada cultura baseado nos seguintes argumentos a seguir transcritos (ARACRUZ, 2010):

atende às necessidades de consumo de madeira e contribui para preservar as florestas e sua contribuição para o desenvolvimento sustentável do Brasil é crescente, ajudando a proteger o meio ambiente, sendo elemento fundamental na mitigação das mudanças climáticas globais;

seu consumo de água é semelhante ao das florestas nativas, além de suas raízes não alcançarem a superfície dos lençóis freáticos;

pode ser cultivado em terrenos de baixa fertilidade natural, não exigindo grande quantidade de nutrientes e defensivos agrícolas, comparado a outras culturas e, também, não requer grandes movimentos da superfície do solo;

seguindo manejo adequado, suas culturas propiciam proteção contra erosão e não afetam a biodiversidade, refutando a acusação de que elas criam "desertos verdes";

Para que se possam analisar as assertivas destacadas anteriormente deve-se realizar uma análise mais crítica e sistematizada de tais conceitos, uma vez que possuem limitações do ponto de vista metodológico.

Como ressaltado anteriormente no corpo da presente pesquisa, quando o objeto de estudo for meio ambiente é necessário se fazer uma análise sistêmica e não fragmentada, ou seja, não 
se trata da análise da cultura do eucalipto em si, mas todas as suas inferências no meio em que esta se localiza.

Em diversos estudos encomendados pelas empresas do setor que se utilizam do eucalipto como fonte de matéria prima se constata parâmetros exclusivos de análise para justificar a sustentabilidade da monocultura de eucalipto, sem que haja essa interação sistêmica de analise do meio.

O meio ambiente, por sua vez, não é algo desconectado da realidade, mas sim esta própria, com suas hierarquias específicas e uma conectividade de inúmeras facetas. A análise pura e exclusiva de uma dessas facetas em separado não dá ideia ou exprime a realidade de um todo.

Dividir nesse caso, é negar a existência de uma realidade muito complexa, sistêmica e interativa, que comporta análises abrangentes. Esse é a realidade mais árdua do campo de análise do meio ambiente, negá-la e simplesmente anulá-la. Sem dúvida, é o que o torna o mais intrigante, prazeroso e rico campo de análise científica.

Realmente, o que se aplica é a metodologia da subdivisão, com detalhes tão específicos que se perde a noção do todo. Utiliza-se o método de "dividir para conhecer" a realidade, como se o conhecimento do meio ambiente fosse uma simples soma de suas partes (BRANCO, 1989).

Esse conceito equivocado de estudar o meio ambiente foi apropriado pelo pensamento neoliberal, servindo para justificar os empreendimentos impactantes e permitir a expansão de atividades mediante a transferência para o conjunto da sociedade das suas consequências e de seus custos. Este equívoco, adotado sem nenhum compromisso com os interesses públicos, também está permitindo - a partir de sua crítica - que muitos estudiosos concluírem que é justamente nas relações de interdependência entre as partes da natureza que está a principal fonte do conhecimento (MATTES \& TAGNIN, 2009).

Dessa forma, os impactos gerados pelas atividades agrícolas intensivas em grandes propriedades têm repercussões e efeitos que normalmente, vão muito além dos limites das 
propriedades dos empreendedores, podendo afetar outros ecossistemas e comunidades vizinhas ou localizadas a grandes distâncias (MATTES \& TAGNIN, 2009).

Nesse momento realizar-se-á uma análise mais aprofundada dos elementos ressaltados anteriormente.

a) Atendimento às necessidades de consumo de madeira e contribuição para preservação das florestas e sua contribuição para o desenvolvimento sustentável do Brasil é crescente, ajudando a proteger o meio ambiente, sendo elemento fundamental na mitigação das mudanças climáticas globais;

Nesse tópico específico deve-se ressaltar, sem a sombra de dúvida, que do ponto de vista da sustentabilidade o eucalipto como fonte de matéria prima em substituição a madeira nativa deve ser uma das soluções apresentadas.

No que tange especificamente ao setor de ferro-gusa a substituição de carvão mineral (coque), por carvão vegetal oriundo de eucalipto proveniente de florestas industriais é muito menos poluente em termos de emissão de $\mathrm{CO}_{2}$ atmosférico.

Acontece que o discurso das empresas do setor é bem distante das práticas e ações efetivamente empregadas.

O que se observa é a expansão progressiva da monocultura de eucalipto para atendimento da demanda de mercado, ou seja, há uma forte pressão das "florestas plantadas" em detrimento de áreas cobertas por matas nativas.

Entre 1997 e 2006 o percentual de carvão vegetal produzido no país a partir de mata nativa passou de 24,6\% para 49\% (AMS, 2007). Na Amazônia Oriental pesquisadores da UFPA indicam que cerca de $60 \%$ do carvão que abastece essas guseiras é feito sem o devido 
licenciamento (CAMARGO, 2006); para o IBAMA, esse percentual chega a quase $80 \%$ (BRASIL, 2005).

Existem vários parâmetros para se calcular a necessidade de terra e diferentes autores utilizam valores diferentes. Considerando a média nacional de uso de madeira (ANDRADE et al., 2003), se toda a produção de ferro-gusa do Brasil dependesse de carvão vegetal, seria necessário derrubar todo ano uma área de aproximadamente 7.463,73 mil ha, o equivalente a 1,7 vezes o estado do Rio de Janeiro. (MILANEZ \& PORTO, 2008)

Na realidade o que se tem é no fundo uma substituição de matas nativas, que foram previamente degradadas por outras culturas anteriormente (como por exemplo a monocultura de soja e a pecuária extensiva de corte de gado que retira a mata nativa para a introdução de pastagens para o gado) por implemento de florestas industriais de eucaliptos.

Dessa forma pelo aumento da demanda cada vez maior por madeira reflorestada o que há na verdade é a implantação dessa monocultura que se expande cada vez mais em direção as matas nativas e áreas que são legalmente protegidas.

Para que se tenha uma ideia dessa problemática ressalte-se que a nova redação do Código Florestal, em discussão atualmente na câmara dos deputados, prevê a utilização de áreas de plantio em topos de morros, que pela legislação vigente, é eminentemente proibida.

De fato, um dos maiores motivos de atuações e multas impostas as empresas do setor são no plantio de reflorestamentos em áreas de proteção permanente.

Por fim, o que se percebe é que a produção de carvão vegetal de madeira nativa aumenta, por conseguinte, o desmatamento e a perda da diversidade, estabelecendo-se um nítido consorcio entre desmatamento e aumento das áreas de reflorestamento, dando origem ainda mais aos conflitos socioambientais. 
Tal problemática vem sendo paulatinamente discutida, uma vez que a introdução de plantas exóticas é considerada uma das principais causas de ameaças à biodiversidade nativa e também por criar formas de conflitos entre distintos usos que se fazem em cada região.

Na realidade as atividades humanas passam a transformar os ecossistemas modificando sua estrutura e seu funcionamento. Desta forma, é alterada a capacidade de promover serviços e bens. A introdução de alguns cultivos poderá levar à perda de outros potenciais usos, tais como produção ecologicamente correta (agroecologica, orgânica etc.), turismo, entre outros (CHOMENKO, 2007).

Também se deve ter presente que as atividades de silvicultura levam a uma série de impactos indiretos, que normalmente não são internalizados no computo dos processos produtivos como efeitos adversos, tais como danos causados às estradas e rodovias por onde transitam caminhões e máquinas agrícolas (cuja restauração e manutenção são realizados com recursos públicos, que poderiam ser direcionados para outros fins com muito maior abrangência e importância social), além do monitoramento ambiental para acompanhar a evolução das mudanças nos ecossistemas. Estes custos acabam sendo socializados pela população em geral, e o recurso financeiro dispendido para redução destes impactos acaba sendo retirado de outras finalidades de interesse comum a toda sociedade (CHOMENKO, 2007).

Gradativamente os investimentos por parte das multinacionais plantadoras de eucalipto são incentivados pela iniciativa Pública por meio de incentivos fiscais, linhas de crédito diferenciadas, sob a bandeira de desenvolvimento sustentável.

$\mathrm{Na}$ realidade a produtividade sustentável alegada mascara uma complexa teia de diferentes impactos ambientais. O exemplo do cerrado brasileiro, mais especificamente no estado de Minas Gerais, mostra que determinadas regiões eram historicamente constituídas pela produção de alimentos por meio de lavouras e a criação de gado extensiva, estabelecendo uma população de agricultores e uma diversidade de práticas de uso da terra e da fauna e da flora foi 
expropriada pela demanda industrial de matéria prima pelas siderúrgicas do estado (TALPO, 2011).

Embora teoricamente considerado recurso coletivo por causa dos múltiplos jogos de interesses na sociedade, os recursos naturais passam a ser objeto de apropriação privada por ação dessas empresas e por outros usos diversos. Isso remete para o reconhecimento do meio ambiente como um campo de tensão permanente entre interesses individuais e coletivos (MAIA, 2009).

Os interesses individuais podem ser caracterizados como sendo aqueles que orientam ações e práticas nas quais prevalece a lógica do uso privado dos bens públicos. Este modo de uso dos recursos naturais pode acarretar danos ao meio ambiente, na medida em que afeta sua disponibilidade para outros segmentos da sociedade e incorre em prejuízos no que refere ao uso comum dos recursos (SCOTTO \& LIMONCIC, 1997).

No caso específico da produção monocultura de eucalipto fica evidente que os interesses do capital privado não observam questões coletivas locais o que gera, por conseguinte, um aumento da tensão pelo uso do solo nas regiões em que este é implantado.

b) Consumo de água do eucalipto é semelhante ao das florestas nativas, além de suas raízes não alcançarem a superfície dos lençóis freáticos.

Essa, sem sombra de dúvida, é uma das questões mais conturbadas em torno das monoculturas de eucalipto. Estudos mostram valores elevados de perda hídrica, sendo por isto responsável pela redução da umidade do solo e destruição dos processos de recarga da água subterrânea, contribuindo para a desestabilização do ciclo hidrológico. (JAYAL, 1995 apud LIMA, 1996) 
Esclareça-se nesse ponto que a análise da questão hídrica referente ao eucalipto não pode ser levada em conta a comparação com outros tipos de culturas isoladas ou até mesmo com outras florestas nativas que não façam parte do contexto em que este está inserido.

$\mathrm{Na}$ verdade a questão central para compreensão é o entendimento do comportamento e interação florestal com os próprios componentes florestais e o meio ambiente e se esta interação contribui para a conservação da biodiversidade (MATTES \& TAGNIN, 2009).

O aumento das áreas de eucalipto está em franca expansão. Nesses sistemas monocultores foi determinada perdas de solo e água durante quatro anos em Areia Quartzosa cultivada com Eucalyptus grandis (LIMA, 1996). Conclui o autor que as perdas para o primeiro ano foram de 1,0 a 6,5 $\mathrm{tha}^{-1}$ ano $^{-1} \mathrm{e}$, para o quarto ano, de 0,01 a $0,14 \mathrm{t} \mathrm{ha}^{-1}$ ano $^{-1}$, observando-se uma diminuição acentuada de perdas de solo com o tempo de cultivo.

Desde 1936, estudos comprovam que a implantação de eucalipto na África do Sul exauriu a capacidade hídrica local, secando nascentes e reduzindo a vazão dos rios, conforme constatado pelo monitoramento de uma rede de mais de setenta estações implantadas para avaliar o impacto das plantações homogêneas de eucalipto e de Pinus sobre os recursos hídricos naquele país (WITT, 2001).

Não há mais discussões na África do Sul que a utilização de árvores como o pinus e o eucalipto tem grande impacto sobre o suprimento de água. Na realidade, o foco da discussão está centrado na dimensão do impacto, tendo em vista a variabilidade climática do país analisado, que dificulta resposta mais precisa (WITT, 2001).

A revista científica SCIENCE, editada pela American Association for the Advancement of Science (AAAS), publicou (vol.310, 23/12/2005, p. 1944-1947) um artigo sob o título "Trading Water for Carbon with Biological Carbon Sequestration" e assinado por ROBERT B. JACKSON, ESTEBAN G. JOBBÁGY' RONI AVISSAR, SOMNATH BAIDYA ROY, DAMIAN J. BARRETT, CHARLES W. COOK, KATHLEEN FARLEY, DAVID C. LE MAITRE, BRUCE A. MCCART ${ }^{7}$ E BRIAN C. MURRAY (SCIENCE, 2005 apud IGRE, 2012). 
$\mathrm{O}$ referido artigo destaca que a contagem do sequestro de carbono somente pela a introdução das árvores pode ser extremamente prejudicial, uma vez que não se leva em conta as reais consequências ambientais (SCIENCE, 2005 apud IGRE, 2012).

Retratam e comparam os autores o resultado de observações de campo com modelagem climática e econômica, afim de demonstrar perdas substanciais e altamente significativas no fluxo dos rios, salinização e acidificação elevados em consequência do florestamento. As plantações reduziram globalmente o fluxo fluvial por 227 milímetros por ano (52\%), e $13 \%$ dos rios secaram completamente durante no mínimo um ano. Modelagens regionais realizadas no EUA sugerem que o sequestro de carbono obtido com o plantio do eucalipto dificilmente poderia compensar tais perdas, podendo até intensifica-las (SCIENCE, 2005 apud IGRE, 2012).

Outros estudos demonstram os efeitos negativos das florestas plantadas com espécies exóticas sobre os recursos hídricos. As referências a seguir são significativas:

““Streamflow responses to afforestation with Eucalyptus grandis and Pinus patula and to felling in the Mokobulaan experimental catchments, South Africa" é o título de um artigo publicado por DAVID F. SCOTT E W. LESCH, ambos do Jonkershoek Forestry Reseacrh Centre (CSIR) em Stellenbosch, África do Sul, no Journal of Hydrology [v.199 (1997):360-377]

Os autores descrevem a redução do volume fluvial após florestamento de paisagens de campo com Eucalyptus grandis e Pinus patula nas áreas experimentais de drenagem de Mokobulaan e das escarpas de Mpumalanga e ainda, as respostas subsequentes ao abate das plantações. Florestamento com Eucalyptus causou um decréscimo significativo da descarga fluvial no terceiro ano após o plantio e no nono ano, o rio secou completamente. Os eucaliptos foram derrubados após 16 anos, mas o retorno pleno da descarga fluvial ainda não havia ocorrido no quinto ano subsequente. Florestamentos com Pinus igualmente resultaram em 
decréscimo da descarga fluvial a partir do quarto ano e o rio secou inteiramente no décimo segundo ano após o plantio" (IGRE, 2007).

Sob o titulo "Invasive alien trees and water resources in South Africa: case studies of the costs and benefits of management", publicado em Forest Ecology and Management 160 (2002) 143-159, os pesquisadores D.C. LE MAITRE, B.W. VAN WILGEN, C.M. GELDERBLOM, C. BAILEY, R.A. CHAPMAN E J.A. NELA, ligados ao CSIR Division of Water, Environment and Forestry Technology, P.O. Box 320, Stellenbosch 7599, South Africa e ao CSIR Division of Water, Environment and Forestry Technology, P.O. Box 395, Pretoria 0001, South Africa relatam que plantas exóticas invasivas estão reduzindo a descarga fluvial na África do Sul, em níveis de até 6,7\% de acordo com estudos realizados em larga escala. Segundo os autores, um programa efetivo capaz de colocar as invasões sob controle custaria cerca de US\$ 92 milhões por ano durante os próximos 20 anos. (IGRE, 2007).

$O$ artigo relata os estudos realizados nas bacias de Sonderend, Keurbooms, Upper Wilge e Sabie-Sand. As principais invasoras das bacias fluviais são o Pinus no Sonderend e Keurbooms, Eucalyptus no Upper Wilge e Pinus, entre outros, no Sabie-Sand. As invasões das bacias são dominadas por Acacia mearnsii e por A. dealbata. A primeira, conhecida no Brasil como "Acácia negra", já é plantada no nosso país em larga escala. Considerando-se a atual taxa de expansão das invasões, estima-se que a redução do volume de água dos ambientes lóticos atinja 41,5, 95,5, 25,1 e 22,3\%, respectivamente, em cada bacia, durante os próximos 23 anos. (IGRE, 2007).

V. C. MORAN, J. H. HOFFMANN, D. DONNELY, B. W. VAN WILGEN E H. G.ZIMMERMANN, em seu artigo "Biological Control of Alien, Invasive Pine Trees", (Pinus species) in South Africa", publicado em Proceedings of the X International Symposium on Biological Control of Weeds (4-14 July 1999, Montana State University, Bozeman, Montana, USA, descrevem um ambicioso programa de longo alcance, o "Working for Water", cujo custo é avaliado em US\$70 milhões por ano e empregando cerca de 42.000 pessoas, tendo objetivos 
fortemente conservacionistas e a meta de aumentar o suprimento de água para a África do Sul. O programa pretende aumentar as descargas fluviais pela remoção das espécies arbóreas invasivas, especialmente das espécies de Pinus, das bacias e dos cursos fluviais. (IGRE, 2007).

Importante se frisar que o eucalipto já foi utilizado para a realização da retirada de água do solo em diversas regiões do Brasil. Deve-se destacar o caso da City of São Paulo, conforme destacam alguns professores da Universidade Federal do Rio Grande do Sul em documento intitulado: Por que respeitar o zoneamento, extraído do sito da IGRE - Associação SócioAmbientalista:

Talvez o exemplo mais representativo seja o caso da empresa paulistana fundada em 1912 com o nome de "City of São Paulo Improvements and Freehold Land Company Limited ", a Companhia City, como ficou conhecida. A empresa contratou os urbanistas ingleses BARRY PARKER e RAYMOND UNWIN para o projeto de um bairro que ficaria conhecido como Jardim América. Previamente a isso, a Cia. City havia adquirido duas áreas que totalizavam aproximadamente $960.000 \mathrm{~m}^{2}$ e localizadas na antiga Chácara Bela Veneza e na Freguesia da Consolação que eram áreas inóspitas e inundadas em boa parte do ano por estarem situadas na várzea do Rio Pinheiros. Para drenar as terras próximas constantemente alagadas, a partir de 1927 foram plantados milhares de eucaliptos, que em poucos anos cumpriram a sua missão. Transformaram as áreas pantanosas influenciadas pelas enchentes do rio Pinheiros em bairros de grande valor e alta qualidade urbanística - o Jardim Europa e o Jardim América. Algumas destas árvores ainda estão lá testemunhando seu papel do passado.

No Brasil, além do já citado estudo de (LIMA,1996) pode-se destacar a contribuição de (SILVA \& GONÇALVES, 2004) que ressaltaram o incentivo da expansão da monocultura de eucalipto em Minas Gerais, na década de 1970, para áreas de chapadas, antes coberta por cerrados. 
Segundo os autores o governo federal tinha uma política de defesa de proteção ao bioma amazônico em detrimento das áreas de cerrado, pois o consideravam esse bioma um conjunto de árvores inúteis, baixas e tortas. (SILVA \& GONÇALVES, 2004).

Concluem que foi ignorado o verdadeiro papel hidrológico que as chapadas desta região têm na recarga hídrica, responsáveis pelo abastecimento do lençol freático que alimenta as nascentes e córregos e, por conseguinte, as bacias do São Francisco, Jequitinhonha e Pardo.

Os próprios autores destacaram a importância hídrica da região ao afirmarem (SILVA \& GONÇALVES, 2004):

"Essas chapadas fazem do cerrado a grande caixa d'água do território brasileiro, fato percebido pela sensibilidade do nosso grande Guimarães Rosa, nas duas passagens belíssimas do Grande Sertão Veredas. Os cerrados das chapadas transpiram entre 1,5 mm (na seca) e 2,5 mm (nas águas) de água por dia. Possuem cascas grossas, folhas coriáceas e portentoso sistema radicular, todos elementos que lhe propiciam uma grande capacidade de economia de água. $O$ que era considerado um defeito - a baixa altura de suas árvores -, na verdade, nas condições climáticas e de solo domínio do bioma, e do Norte de Minas em especial, se constitui numa grande virtude. A baixa produção de biomassa - as savanas produzem em média de 10 a 20 toneladas de biomassa por hectare - desses cerrados também é um fator de economia de água, o que permite que a chuva que cai se infiltre no solo e, assim, abasteça o lençol freático e as fontes, córregos, brejos e várzeas, que propiciaram a ocupação humana e a vida dos povos dos cerrados."

Dessa forma com a monocultura do eucalipto o que se vê é uma realidade bem distinta de análise, pois a transpiração deste é na ordem de $6 \mathrm{~mm}$ de água dia e produz uma quantidade de biomassa nessa localidade na ordem de 100 a 150 toneladas por hectare. Com a devida ressalva de que $2 / 3$ da biomassa dos seres vivos é constituída de água (SILVA \& GONÇALVES, 2004).

A conclusão do referente estudo é que: 
“ (..) a água contida na maior biomassa da monocultura era a água que, antes, quando havia ali o cerrado, alimentava o lençol freático que mantinha as nascentes e os córregos desses locais. Não é à toa, portanto, que as populações do cerrado vêm denunciando os estragos da monocultura, em especial sobre as fontes de água que abasteciam as comunidades pelas Gerais afora. Alguns cientistas querem desqualificar essa percepção certeira das comunidades rurais que sofrem na pele esse impacto, taxando-a de 'sem embasamento cientifico'. (...) O complexo reflorestador-siderúrgico-celulósico é, rigorosamente, do ponto de vista científico, agente de um modelo produtivo que impacta cerrados, água e gente e que de sustentável não tem nada. (...)”

No mesmo sentido é o posicionamento da ONU por meio de seu organismo internacional de agricultura (FAO 1987):

“En cualquier bosque, la interceptación representa la pérdida de agua más importante de todo el sistema. Esto se debe a que la mayoría del agua interceptada, se volverá a evaporar sin alcanzar el suelo. (...) En términos generales, los eucaliptos parecen interceptar entre un $11 \%$ y un $20 \%$ de la precipitación. Este valor es menor que en los pinos, pero superior a la vegetación baja. Los resultados de la comparación de los eucaliptos com otras especies de frondosas, son contradictorios. [obs.: como o índice de área foliar do eucalipto é tipicamente menor que o de outras espécies florestais, é de esperar que a perda total de água pluvial por interceptação do eucalipto seja menor que a de outras espécies florestais. (...) La plantación de extensos bosques de eucalipto en cualquier cuenca deforestada, reducirá sustancialmente la producción de agua de esa cuenca, y la tala de estos bosques la aumentará. El efecto de los eucaliptos sobre la reducción de la producción de agua, es probablemente menor que el de los pinos y mayor que el de otras especies de frondosas; pero todas las especies arbóreas, reducen la producción de agua en mayor proporción que el rastrojo y el pasto.

En consecuencia, cuando es importante la producción de agua de la cuenca o el estado de la capa freática en las tierras bajas adyacentes, debe considerarse muy cuidadosamente la situación antes de realizar grandes programas de repoblación forestal o dedeforestación."

Outros estudos com silvicultura de eucalipto mostram a questão do impacto hidrológico na região de sua respectiva implantação. Na região central de Belo Horizonte, Minas Gerais, 
mostrou-se a comprovação de que o eucalipto, na forma em que é cultivado e explorado no Município de Caeté, contribui diretamente para a aceleração de processos erosivos nas encostas (erosão laminar) e para a degradação da qualidade da água naquele município (SALGADO \& MAGALHÃES JR, 2006).

O consumo elevado de água não só pelo eucalipto em solo como o setor de papel e celulose representa um dos impactos mais contundentes, uma vez que utiliza-se em média $57 \mathrm{~m}^{3}$ de água para produzir uma tonelada de pasta celulósica. Assim, para atingir o montante transformado em 2005, foram gastos aproximadamente $577.191 .063 \mathrm{~m}^{3}$ de água. Considerando que o padrão médio de consumo das residências e estabelecimentos comerciais do estado de São Paulo é da ordem de $168 \mathrm{~m} / \mathrm{ano}$, o volume gasto pelas empresas produtoras de celulose seria suficiente para abastecer mais de 3 milhões e 400 mil domicílios, ou cerca de 11 milhões e 900 mil pessoas, em um mesmo período de tempo (LASCHEFSKI \& ASSIS 2006).

Através de vários processos fisiológicos comparativos entre distintos ecossistemas, constata-se que numa plantação florestal, embora os ganhos por fixação sejam mais elevados, o balanço líquido final é negativo, pois as perdas pelos processos de colheitas das árvores são muito maiores (CHOMENKO, 2007).

Considerando-se uma maior taxa de fixação de carbono nas árvores, comparativamente com outros ecossistemas, também logo se associam maiores perdas de água através de processos de transpiração, restringindo, desse modo, a disponibilidade para outros usos (águas superficiais ou subterrâneas). Esta perda pode resultar em danos extremamente críticos de disponibilização da água em diversas fases do ano, e com consequências adversas que podem ser da maior gravidade em relação tanto aos recursos ambientais quanto humanos. (CHOMENKO, 2007).

Pode-se tomar como exemplo estudo realizado no norte de Minas Gerais evidenciandose a ação subtrativa do eucalipto e do pinus, embora este último numa proporção menor, na 
recarga regional, no município de Grão Mogol, diminuindo-a em cerca de $230 \mathrm{~mm}$ de água anuais. (LIMA, 1990)

Cabe lembrar que a supressão da vegetação nativa do cerrado e implantação da floresta homogênea de eucalipto desequilibra o balanço hídrico local.

Estudos mostram que vegetação nativa da região está adaptada aos padrões hídricos e climáticos regionais, ao contrário do eucalipto e do pinus, apesar de terem produtividades muito superiores, não conseguindo equilibrar a sua demanda evapotranspirativa com a da vegetação nativa, ocasionando um decréscimo na recarga nas áreas de chapadas reflorestadas da ordem de $164 \mathrm{~mm} /$ ano. Assim contribuem para realçar ainda mais a escassez hídrica na região norte de Minas Gerais. (OLIVEIRA, MENEGASSE \& DUARTE, 2002)

Ainda para reforçar a tese da questão da alteração hídrica do plantio de monocultura de silvicultura temos um indicador biológico: a presença de alguns tipos de formigueiros nos eucaliptais.

Nas áreas reflorestadas com eucalipto são efetuados vários combates às formigas, especialmente as das espécies dos gêneros Atta e Acromyrmex, consideradas grandes pragas de do reflorestamento brasileiro. Os tipos de combate mais comuns são o localizado (utilização de formicidas sobre os ninhos) e o sistemático (as iscas formicidas).

Há estudos indicando que cerca de $75 \%$ dos custos e tempo gastos no manejo integrado de pragas em florestas plantadas, ou 30\% dos gastos totais até o terceiro ciclo eram destinados ao manejo integrado de formigas. O desfolhamento causado por formigas pode reduzir a produção de madeira no ano seguinte em um terço e, se isto ocorrer no primeiro ano de plantio, a perda total do ciclo pode chegar a $13 \%$ da colheita. Em ecossistemas tropicais as formigas consomem em média $15 \%$ da produção florestal. A presença maciça desse inseto também é indicativa de ambiente mais seco ou de alteração hídrica local (ANJOS, 1993). 
Dessa forma inúmeros estudos conclusivos mostram a temática da perda hídrica pela utilização da silvicultura de eucalipto, não podendo de forma alguma, serem desconsiderados quando da implantação dessas em uma área específica.

Além do mais, conforme já ressaltado anteriormente no corpo desse trabalho, não se deve deixar de levar em consideração a percepção das comunidades locais, que por meio da experiência vivida relatam grandes constatações, que muitas vezes são mais elucidativas e racionais do que os caracteres "científicos" dados a pesquisas burocratas e financiados por grupos com interesses obscuros na implantação dessas monoculturas.

c) O eucalipto pode ser cultivado em terrenos de baixa fertilidade natural, não exigindo grande quantidade de nutrientes e defensivos agrícolas, comparado a outras culturas e, também, não requer grandes movimentos da superfície do solo;

Com relação ao argumento acima ventilado deve-se tomar cautela com as afirmações corriqueiramente tecidas a cerca do tema. Primeiramente, o uso de nutrientes do solo e quantidade de defensivos agrícolas está diretamente ligado à relação que se faz entre a cultura eleita para o plantio e a colheita que se "espera" obter desse investimento.

Importante ser ressaltado que a cultura de eucalipto como outras monoculturas está atrelada a um modo capitalista de produção, onde se visa o lucro acima de qualquer outro elemento de análise.

As plantações de eucalipto e pinus, desenvolvidas em grandes áreas de monocultivo, são altamente dependentes de agroquímicos. Como em qualquer outra monocultura, a contaminação dos solos e da água superficial e subterrânea não pode ser evitada, mesmo quando os produtos químicos são aplicados de forma controlada (SCHLESINGER, 2008). 
Alguns estudos mostram que em decorrência de ciclos acelerados de cultivo do eucalipto o solo entra em grande processo de degradação, bem como se acentua a perda hídrica das microbacias onde se estabelece o cultivo.

Entrevistas com moradores de regiões que foram intensamente modificadas pela implantação da cultura de eucalipto mostram a questão da degradação do solo e a utilização de cargas excessivas de agrotóxicos, conforme se destaca no trabalho de alguns autores (LASCHEFSKI \& ASSIS, 2006):

"Além disso, em decorrência dos ciclos acelerados de crescimento dos plantios-entre 5 e 7 anos -, estabelece-se um regime de águas profundamente alterado em comparação com as condições naturais. Alguns moradores entrevistados em 2004 nos municípios de Curvelo e Felixlândia confirmaram a disponibilidade súbita de muita água após o corte raso de plantios próximos às veredas. Porém, em função das altas cargas de sólidos em suspensão e de agroquímicos oriundos dos solos descobertos nas áreas desmatadas, a água era inadequada para o uso doméstico. Assim, pode-se constatar que as plantações de eucalipto causam alterações significativas, incluindo áreas além dos seus limites."

Sendo assim, no plantio do eucalipto são utilizados produtos químicos (herbicidas) para a eliminação das plantas daninhas, as chamadas plantas invasoras, principalmente na fase inicial do seu cultivo e agrotóxicos para enfrentar o ataque das pragas, como é o caso do fungo chrysoporthe cubensis e podem ser empregadas tanto nas áreas de cultivo e produção de mudas, nos viveiros (SOUZA, 2007).

O esgotamento do solo se deve pelas atividades de silvicultura ter suas erosões concentradas nas camadas superficiais do solo onde se verificam os fenômenos biológicos mais importantes para a decomposição da matéria orgânica e para o desenvolvimento da vegetação, isso provoca a perda dos nutrientes e o seu empobrecimento (MATTES \& TAGNIN, 2009). 
Os materiais transportados acabam sendo conduzidos para os corpos d’água, alterando a sua qualidade, provocando a eutrofização das águas. A contaminação das águas também se dá pelo transporte de agrotóxicos e fertilizantes transportados juntamente com as partículas dos materiais carreados (MATTES \& TAGNIN, 2009).

O plantio de "florestas de eucaliptos" em substituição da vegetação natural provoca uma desestruturação do equilíbrio natural dos solos e perda da biodiversidade local e regional.

Os autores citados anteriormente destacam que em relação ao plantio de eucaliptos no bioma dos pampas gaúchos, por exemplo, os impactos (físicos e químicos) provocados por essas culturas, se manifestam, portanto, tanto na área de plantio propriamente dita, contribuindo para a degradação dos solos, como nos cursos d’água, alterando a sua qualidade e influindo na vida aquática, além dos efeitos secundários decorrentes em toda a cadeia ecológica (MATTES \& TAGNIN, 2009).

Outro relato da utilização de agrotóxicos e outros defensivos agrícolas por parte da silvicultura foi realizada pelo Defensor Público do Estado de São Paulo, Wagner Giron de La Torre que ao conceder entrevista na revista IHU online ressaltou o trabalho da Defensoria Pública do Estado de São Paulo no município de São Luiz do Paraitinga:

“Nós da Defensoria Pública de São Paulo na região do Vale do Paraíba, por meio de visitas locais de monocultura junto à população rural e campesina aqui da região, temos verificado que os principais impactos sócio-culturais do eucalipto têm se dado no secamento de recursos hídricos, no esgotamento de fontes de água, secamentos de cursos de rios, ribeirões e cachoeiras. Além disso, tem a contaminação do ecossistema, principalmente do solo e dos corpos hídricos, em função das toneladas de pesticidas, herbicidas à base de glifosato, utilizados no manejo do eucalipto, não só na época da semeadura das mudas clonadas, mas de seis em seis meses dentro das linhas eucaliptais para fazer a capina química. Tem ocorrido a morte de muitos peixes, equinos, bovinos e até de pessoas em função do glifosato. Tudo isso somado a 
grandes extensões de plantação de eucaliptos por milhões de hectares no Vale do Paraíba. São latifúndios recobertos de eucaliptos para a indústria de celulose. A defensoria pública tem constatado junto às populações rurais um enorme índice de êxodo rural, cerceamento das atividades culturais e tradicionais das populações, porque os latifúndios estão invadindo locais tidos como sagrados para os campesinos impedindo o desenvolvimento de atos devocionais, de feitura de rezas e orações. Os impactos são bastante amplos” (grifos nossos)

d) seguindo manejo adequado, suas culturas propiciam proteção contra erosão e não afetam a biodiversidade, refutando a acusação de que elas criam "desertos verdes"

Refuta-se tal argumento diante de uma simples observação de que toda monocultura em grande escala retira a biodiversidade de um determinado local, uma vez que ao substituir um bioma nativo, seja ele qual for, é por óbvio, a perda da pluralidade dos elementos biológicos.

Ou seja, a implantação de uma monocultura é a imposição de um determinado microambiente em relação a seu próprio macro, haja vista que numa única cultura não há a pluralidade de fornecedores, consumidores e decompositores.

Qualquer bioma é composto por várias tipologias de vegetação e de ecossistemas integrados e inter-relacionados e que funcionam de forma equilibrada. Significa que para assegurar a biodiversidade, é necessário que os seus espaços não sejam segmentados (MATTES \& TAGNIN, 2009). 
Ainda, mesmo que se utilizasse de um manejo adequado, coisa que não se traduz na realidade, conforme vimos, em diversos momentos, no corpo dessa obra seria impossível dizer que a silvicultura monocultora de eucalipto não afeta a biodiversidade do local.

Tal afirmativa leva crer que existe uma necessidade de se criar um "slogan", por parte das empresas do setor, em prol dessa atividade, como se fosse a única solução para se atingir a sustentabilidade ambiental.

Importante se frisar que tipo de sustentabilidade e quais os reais interesses desse tipo de discurso na ótica do capital. A expressão "deserto verde" surgiu tendo em vista não apenas a questão do déficit hídrico, empobrecimento e perda de solo, já anteriormente discutidos, mas também o baixo número de espécies vegetais e animais que o cultivo da monocultura de silvicultura de eucalipto proporciona.

Com relação ao efeito no solo envolvendo outros elementos, demonstra-se uma acidificação e uma maior concentração de algumas bases promovendo alguns câmbios químicos (acidificação, salinização, perda de nutrientes), que são irreversíveis, comprometendo seriamente a fertilidade e, portanto, o potencial produtivo dos solos. No que se refere à substituição da cobertura vegetal de ecossistemas por uma única espécie, há efeitos diretos e severos nas cadeias tróficas e perda da informação ecossistêmica e genética (CHOMENKO, 2007).

Deve-se chamar a atenção que processos erosivos também são decorrentes da alteração do balanço hídrico que a silvicultura pode causar na região de sua implantação. No caso específico do pampa gaúcho pode-se chamar a atenção para o processo de salinização.

Os índices pluviométricos são diferentes entre as regiões o que ocasiona menor disponibilidade de umas sobre outras. Nas regiões com grandes plantações de eucalipto pode haver uma redução do suprimento de água para os rios o que ocasiona graves consequências socioambientais. De fato o que ocorre é que as raízes mais profundas do eucalipto em relação a 
capins e ervas do campo movimentam depósitos de água subterrânea mais profunda, trazendo junto os sais lá acumulados, podendo ocasionar a salinização na região (BENCKE, 2008).

Ressalte-se que a implantação dos "desertos verdes" não gera perda direta somente da biodiversidade da fauna e flora, conforme ressaltado anteriormente, mas também quando da substituição da vegetação nativa descaracteriza por completo a paisagem da região, modificando dessa forma seu espaço geográfico.

Em áreas turísticas, onde não há o respeito pelo bioma local, isso pode comprometer a renda da localidade que deixará de receber seus turistas habituais em consequência da descaracterização da paisagem tradicional, o que gera impacto na economia local e principalmente afeta a população local que está diretamente ou indiretamente ligada a esse setor de serviços tal importante.

De tal forma, o que se observa é que se afirma muito por parte das grandes corporações que instalam a silvicultura, tanto no Brasil, quanto no mundo que se "houver um manejo adequado" a silvicultura é uma solução para vários problemas ambientais.

O que ocorre é que esse discurso é falho e na prática esse manejo não possui planejamento adequado e com respeito as legislações ambientais, bem como não resguarda localidades situadas próximas as matas ciliares e córregos de rios, conforme podemos observar na Figura 31.

O mapa retrata a cobertura e uso do solo da bacia hidrográfica do rio de Janeiro, localizada no estado de Minas Gerais. Observe que as áreas em amarelo denotam a expansão da silvicultura na região, uma vez que por seu formato retilíneo mostram o preparo para a instalação de silvicultura.

Ainda, importante destacar, que várias dessas regiões estão localizadas em áreas de mananciais ou até mesmo em áreas de preservação permanente, que são de fundamental 
importância para o desenvolvimento das matas ciliares que na área específica de cerrado dão origem as veredas.

Frise-se que a degradação dos buritizais estão relacionadas ou associadas ao "secamento", bem como ao assoreamento das nascentes. Tal evento é decorrente dos processos erosivos associado ao cultivo de eucalipto

Esse exemplo trazido pelo mapa do referido autor mostra mais uma vez que o discurso de manejo adequado nem sempre é respeitado. O que chama atenção que a área de estudo é limítrofe a área da plantação do Projeto Plantar, e que algumas dessas regiões pertencem ao projeto, denotando, mais uma vez, que a falta de planejamento do manejo atende na verdade a interesses econômicos bem distintos dos interesses ambientais e sociais.

Caso não haja planejamento da expansão da silvicultura pode-se ter um grande colapso dos biomas onde são implantadas. O pinus desvaloriza a terra e onera seu manejo, prejudicando as populações rurais (BENCKE, 2008). 


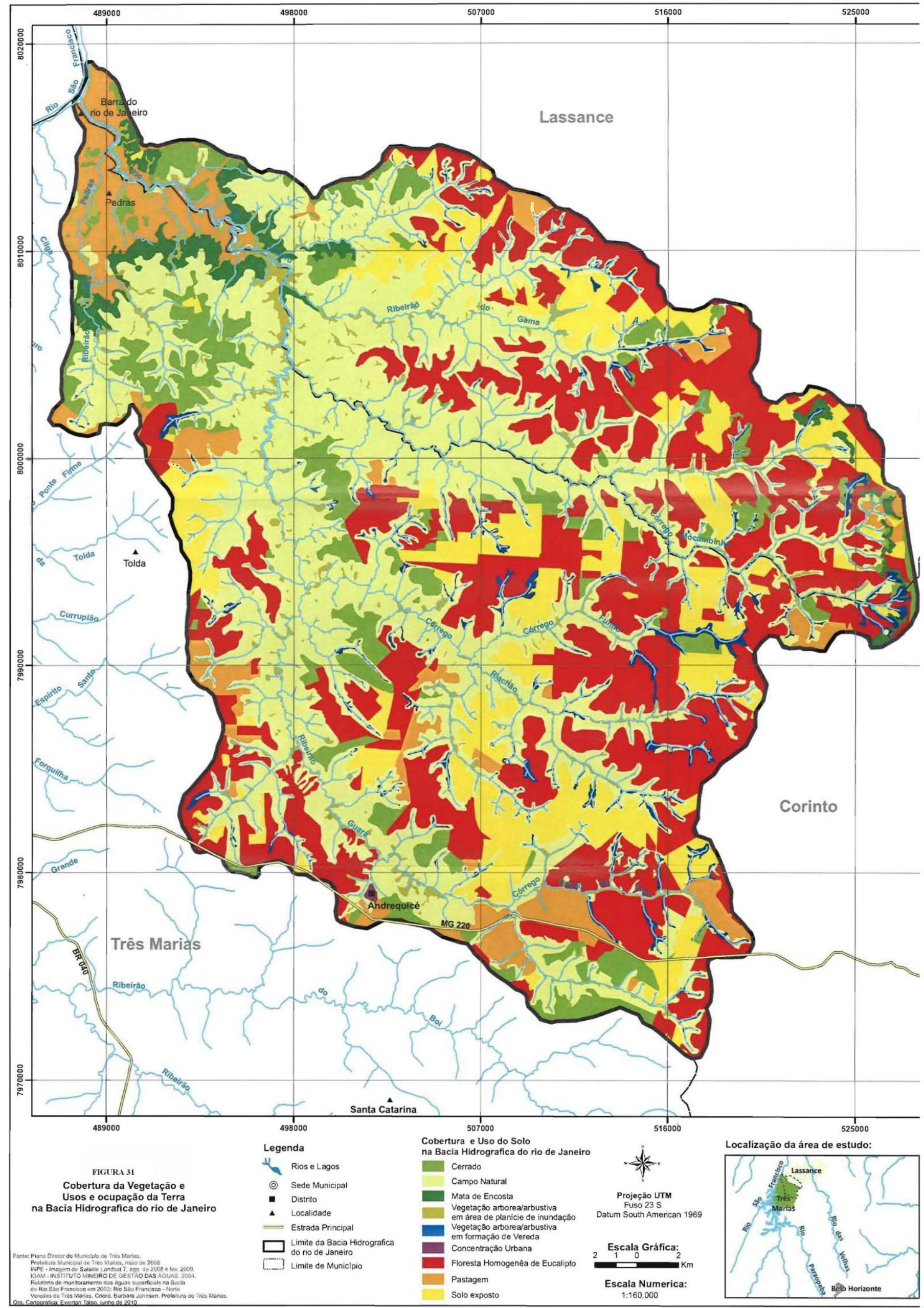


Destaque idêntico para a questão alelopatia que muitas vezes não é considerada no manejo de silviculturas que interfere muitas vezes de forma prejudicial em áreas do entorno desses empreendimentos agroflorestais. Define alelopatia como (RICE, 1984):

"A alelopatia é definida como qualquer efeito direto ou indireto, benéfico ou prejudicial, de uma planta ou de microrganismos sobre outra planta, mediante produção de compostos químicos que são liberados no ambiente."

Estudos mostram que a silvicultura pode gerar efeitos aleopáticos em culturas de leguminosas, conforme experimentos (PAULINO, et al.1987)

Os efeitos da incorporação de folhas ou raízes de eucalipto (Eucalyptus spp.) no desenvolvimento e nodulação das leguminosas forrageiras: soja perene (Neonotonia wightii cv. Tinaroo), desmódio (Desmodium intortum cv. Green leaf), galactia (Galactia striata cv. Yarana) e o capim-colonião (Panicum maximum cv. IZ 1) foram estudados em vasos em dois solos: Podzólico Vermelho-Amarelo variação Lara (de Nova Odessa, SP) e um Latossolo Vermelho-Escuro-orto (de Itapetininga, SP). Pelos resultados obtidos, contatou-se que no solo de Itapetininga, explorado anteriormente com eucalipto, havia efeito inibidor ao cultivo das forrageiras, ao passo que esse fato não ocorreu no solo de Nova Odessa, onde anteriormente não se cultivou eucalipto. A adição de folhas de eucalipto secas e picadas aos vasos resultou em efeitos aleopáticos prejudiciais às três leguminosas, sendo o desmódio o menos sensível e a soja perene a mais sensivel."

Reforçado está dessa forma o argumento sobre a importância de se manter significativa distância entre os maciços de eucaliptos e os espaços ocupados por vegetação nativa ou por outras atividades agropastoris, em especial as que se destinam a produção de alimentos e que tal atitude passa muitas vezes desapercebida ou é ignorada na introdução dessa monocultura. 


\section{CAPÍTULO V - ANÁLISE COMPARATIVA DOS PASSIVOS AMBIENTAIS E PRESTAÇÃO DO SERVIÇO AMBIENTAL.}

5.1 Passivo Ambiental: A monocultura de silvicultura de eucalipto e o aterro sanitário (parâmetros de análise)

O Passivo Ambiental pode ser conceituado como toda a agressão que se praticou e pratica contra o meio ambiente e consiste no valor de investimento necessário para reabilitá-lo, bem como multas e indenizações em potencial (IBRACON, 1995).

Ou seja, resulta em sacrifício de benefícios econômicos que devem ser assumidos para a recuperação e a proteção do meio ambiente, decorrente de uma conduta inadequada em relação às questões ambientais (RIBEIRO, 1995).

Nesse momento da pesquisa far-se-á uma comparação de passivos ambientais de monocultura de eucalipto e os aterros sanitários.

\subsection{A Silvicultura}

No que tange a monocultura de silvicultura de eucalipto destacam-se alguns passivos ambientais (já retratados no corpo da presente pesquisa) como a substituição da vegetação nativa gerando a perda da biodiversidade, erosão, desgaste, esgotamento do solo, perda hídrica (esgotamento de micro bacias), concentração fundiária, reprodução de relações de trabalho injustas e exploração da mão de obra.

Conforme ressaltado anteriormente, o discurso das empresas do setor que utilizam-se dessa monocultura como matéria prima é de que há uma preservação da vegetação natural em decorrência da utilização dos reflorestamentos o que diminui a pressão nessas áreas havendo, por conseguinte, um ganho ambiental. 
Entretanto, o discurso é apenas face de uma meia verdade. De fato, tal assertiva se justificaria se não fosse o fato de ser uma alimentação da própria ótica do capital. Na verdade, conforme demonstrado no corpo dessa pesquisa o que existe é um aumento das florestas plantadas em detrimento da perda da vegetação nativa. Nessa análise devemos chamar a atenção que não há uma relação direta entre aumento da floresta plantada e regeneração de áreas com vegetação nativa. Onde estaria o ganho ambiental?

Ou seja, existe uma substituição continua de matas nativas, que foram previamente degradadas por outras culturas por florestas industriais de eucaliptos. Além do mais é de suma importância se fazer uma análise que o modelo de sustentabilidade eleito pelo Protocolo de Quioto contempla apenas a grande agroindústria do papel, celulose e siderúrgica não havendo o benefício do crédito de carbono aos que mantém a floresta em pé, ou seja, não existe crédito de biodiversidade.

A metodologia utilizada para a aprovação de MDL no que tange ao reflorestamento não pode contemplar financiamento a tal tipo de atividade que não trará adicionalidade, uma vez que o ciclo do carbono é um ciclo de 20 anos e para que haja a efetiva estocagem no solo desse componente é necessário que se tenha um ciclo de igual ou maior valor que 20 anos de permanência no local, não como na maioria das vezes que é cortado em 7 anos após o plantio ou até mesmo 3 anos em alguns casos para utilização na confecção de ferro gusa. Dessa maneira não há que se falar em sequestro de carbono, por conseguinte não há créditos de carbono.

Evitar o desmatamento deveria ser a principal fonte de créditos de carbono. Dessa forma o sistema de MDL privilegia aqueles que desmataram durante décadas e que agora veem a necessidade, inclusive do próprio capital, para praticarem uma melhora e não contempla aqueles que sempre mantiveram a vegetação nativa.

Dessa forma é evidente que existe uma perda dupla da biodiversidade. Primeiro, a eleição do cultivo de uma monocultura, por si só já é a imposição de um sistema que suprime a diversidade biológica. Segundo, a pressão que as florestas plantadas exercem sobre a vegetação 
nativa diminuem cada vez mais o número de espécies e a perda da diversidade biológica desses biomas.

O esgotamento e a perda do solo estão intimamente ligados ao tipo de cultura e ao atendimento das necessidades da indústria do setor. Por óbvio não se contempla nesse sistema o respeito pelo tempo de cultura, muito menos os impactos que sua aceleração causa ao solo.

Conforme demostrado anteriormente o solo é altamente impactado pelo utilização desse tipo de monocultura. Além do mais, os processos convencionais, caracterizados por intensos revolvimento do solo, pode, num período de 15 a 23 anos, reduzir o estoque original de matéria orgânica do solo em até 50\% (EMPRAPA, 2007).

A perda hídrica, conforme explanado no capítulo anterior desta pesquisa, pela utilização da silvicultura de eucalipto é uma percepção não somente da comunidade científica, mas também das comunidades locais. Ou seja, em decorrência de ciclos acelerados de cultivo do eucalipto acentua a perda hídrica das microbacias onde se estabelece o cultivo.

Tais passivos ressaltados aqui já foram objeto de análise do capítulo anterior. Dessa forma a concentração dos esforços de análise ficará por conta da concentração fundiária, reprodução de relações de trabalho injustas e exploração da mão de obra, na implantação dessa monocultura na área de estudo. A justificativa se faz, uma vez que a categoria objeto de estudo em pauta é a própria sociedade.

Em muitas regiões do país as plantações de eucalipto são verdadeiras desmanteladoras das comunidades tradicionais e consequentemente provocam sua extinção. O impacto das monoculturas de eucaliptos não é só ambiental, social e/ou econômico, mas é também cultural.

A chegada das grandes empresas de celulose, no processo de aquisição de terras, acabou por incorporar diversos sítios de produção tradicional e consequentemente essa aquisição implicou na desagregação da agricultura familiar, que culmina com o fim dos grupos de vizinhanças. 
Os danos causados pela monocultura industrial de eucalipto sobre a agricultura familiar é extremamente violento. Em entrevista concedida a revista IHU On-Line, o coordenador do Movimento em Defesa dos Pequenos Agricultores - MDPA, Marcelo Henrique Santos Toledo confirma a alegação de que a silvicultura desagrega a agricultura familiar e é extremamente expropriatória: (TOLEDO, 2011)

"São Luís do Paraitinga já foi considerado como município celeiro do Vale do Paraíba, ou seja, mantinha uma produção agrícola voltada para a policultura de alimentos que abastecia diversas cidades dessa região, litoral norte e até mesmo o sul de Minas. No entanto, atualmente boa parte do seu território encontra-se invadido por milhares de hectares de árvores exóticas de eucalipto e, se não fosse a resistência da sociedade civil, especificamente a do meio rural, a sua articulação e resistência representados pelo Movimento em Defesa dos Pequenos Agricultores - MDPA, a situação seria muito pior. São Luís do Paraitinga estava se tornando um grande celeiro de eucalipto. As plantações extensivas de monocultivos de eucalipto usurpam terras de boa qualidade destinadas à agricultura e, até mesmo, à pecuária de leite. A cada dia que passa querem plantar mais e mais eucalipto. Ao se instalarem, muda tudo nos bairros/comunidades e o primeiro fator negativo é o da migração dos moradores rurais, entre outras mazelas.”

Observe-se que nessa análise o benefício é exclusivo apenas pelas grandes corporações envolvidas no processo da silvicultura, ou seja, desenvolvimento sustentável está longe de atingir o seu perseguido tripé (social, ambiental e econômico).

Dessa forma o que se tem é o destaque para o viés econômico que se beneficia de uma produtividade mais barata aos custos da expulsão de populações tradicionais que foram retiradas das áreas onde se desenvolve a silvicultura. 
Chame-se atenção que desenvolvimento deve estar atrelado a qualidade de vida da população do entorno, bem como da biodiversidade local e que a produtividade deve ser levada em conta ao benefício coletivo e de longo prazo.

Para corroborar com a redação acima ventilada destaca-se o pensamento de (MELGAREJO, 2007):

"Evidentemente, haverá um enorme empobrecimento do bioma, da qualidade de vida, das oportunidades e das possibilidades de desenvolvimento. Já a produtividade não pode ser examinada apenas do ponto de vista da rentabilidade obtida por pequeno número de empresas voltadas ao mercado externo. A produtividade deve ser considerada desde uma perspectiva mais ampla, examinando o desenvolvimento do território, a pluralidade de atividades, os sistemas locais de produção e a qualidade de vida das pessoas, em perspectiva de longo prazo. Uma comparação que leve em conta todos estes preceitos indicará que não é possível manter a produtividade, conservar ou recuperar o ambiente e, ao mesmo tempo, implantar estas megalavouras de eucalipto para exportação de pasta de celulose."

Pode-se ressaltar que a introdução da silvicultura pode levar a perda da identidade cultural das populações do entorno dos megaempreendimentos, haja vista que o padrão cultural é modificado pelo padrão econômico, ou seja, há a descaracterização dos elementos locais sem que exista uma compensação efetiva da melhora da qualidade de vida das populações locais.

Compactua dessa análise a respeitável professora que descreve a perda de identidade do gaúcho pela introdução da silvicultura na metade sul do Rio Grande do Sul, conforme se observa o trecho a seguir: (CHOMENKO, 2006)

A alteração em aspectos de cunho biótico implica a transformação do comportamento das populações humanas residentes na região, visto que é uma característica regional a integração estreita do ser humano com a natureza. Esta mudança comportamental leva há novos fatores que influenciam a própria cultura, podendo induzir à perda da identidade cultural destas populações humanas. Há que se salientar que esta situação 
pode levar à redução da autoestima das pessoas que tiveram seus vínculos tradicionais rompidos, inclusive colocando em risco a própria figura do "gaúcho", que é um tipo humano mundialmente conhecido e admirado".

Uma das alegações feitas pelas empresas do setor de papel e celulose e carvão vegetal para a implantação da silvicultura em determinadas regiões do Brasil é o fato de ser uma atividade altamente geradora de empregos.

$\mathrm{Na}$ realidade, tal fato é escuso e frequentemente equivocado. Deve-se destacar que a empregabilidade é sazonal e que nas últimas décadas tem se verificado uma diminuição nos postos de trabalho, principalmente no momento do corte da floresta homogênea.

Há um projeto, no campo das empresas internacionais, ambicioso da produção de eucalipto para celulose e direcionado aos chamados "países da periferia do sistema capitalista". Alguns países são selecionados a partir de suas características naturais e sociais. Isso é um projeto do mundo globalizado para ampliar a produção de celulose em função da alta demanda mundial por papel, e, consequentemente, por celulose (SUERTEGARAY, 2010).

Os países são escolhidos por conta do menor controle ambiental, menor regulação social e por demanda de terras com preço reduzido. Isso do ponto de vista econômico. Mas gera também grandes problemas sociais. Diferente do que apresentam as empresas de celulose, o trabalho é muito restrito à monocultura do eucalipto, ele é temporário, é de baixa renda e é produtor de miséria nas cidades que acolhem esta população que vai plantar o eucalipto porque todo o processo, inclusive de corte, tem sido mais mecanizado (SUERTEGARAY, 2010).

Para o corte tem-se utilizado maquinário extremamente especializado, com tecnologia de "corte inteligente" padronizando o tamanho do vegetal cortado, cerca de três metros, com uma produtividade média de cento e cinquenta árvores por hora, enfileirando-as para o transporte de tratores. Estima-se que o trabalho realizado manualmente empregaria de 35 a 40 pessoas por turno de trabalho (TALPO, 2011). 
Outro aspecto que deve ser destacado é que existe uma tendência de diminuição dos fornos convencionais de queima da madeira, no caso da obtenção do carvão vegetal, em detrimento da obtenção de fornos automáticos pelas indústrias siderúrgicas que conseguem atingir um poder calorífico maior que os fornos convencionais retendo a energia que é comercializada com as concessionárias de energias locais.

Faz-se necessário o destaque de que a otimização da produção envolve a implantação de tecnologia no processo o que demanda um grande aporte de investimento e capital forçando as empresas a obtenção de financiamentos o que gera, por conseguinte, uma queda na empregabilidade do setor.

Dessa forma, para se aumentar a produtividade além da implementação tecnológica cria-se necessidade do aumento das plantações que são multiplicadas não só pela nova aquisição de propriedades, mas também com o arrendamento de pequenas e médias propriedades que realizavam outros usos da terra, mas que agora se voltam a produção de eucalipto.

Ainda, importante se frisar, que o avanço dessas áreas pressiona diretamente as margens dos cursos d'água e as áreas de matas ciliares, gerando problema de assoreamento de rios diminuição da disponibilidade de água do lençol freático.

O desenvolvimento da silvicultura trouxe a homogeneização de usos diferenciados da terra, com o fim de antigas fazendas, pequenos sítios e ranchos, bem como do manejo da riqueza de biodiversidade como é caso do bioma do cerrado (PORTO GONÇALVES, 2006).

Estudos mostram que a cultura de eucalipto causa expropriação da terra e concentração fundiária, aumentando, por conseguinte, os impactos sociais nas regiões onde são implantadas, principalmente no que tange ao emprego das populações mais carentes e de baixa renda.

Na região do sul da Bahia, por exemplo, existe um autêntico "desastre socioambiental pela integração dos complexos siderúrgicos e da celulose em torno da monocultura do eucalipto 
e pinus, empobrecendo a diversidade biológica, além de causar impactos sociais e culturais, implicando em expropriação, desemprego, êxodo rural e fome” (KOOPMANS, 2005).

No caso ressaltado, o autor argumenta que a agropecuária gera, historicamente, na região, um emprego para cada 24,5 ha, enquanto que a eucaliptocultura trabalha com uma média de um para cada 63 ha. Dessa forma, o avanço do eucalipto gerou em 5 anos um saldo negativo de 11.934 empregos pela compra de terras efetuadas pelas empresas da região (KOOPMANS, 2005)

Em outro estado da federação relatos sobre empregos em regiões de atuação da Aracruz, no Estado do Espírito Santo, aponta que a empresa, na época que buscava financiamento, afirmava que cada hectare de plantação de eucalipto geraria em média quatro empregos diretos, portanto, com seus 247 mil hectares plantados deveria gerar 988 mil empregos. No entanto, gerou apenas 2.031, dados de 2004 (DAVID, 2006).

As pesquisas indicam que desde 1989 até os dias de hoje esta empresa gigantesca gerou 8.807 postos de trabalho, dos quais 2.031 diretos e 6.776 indiretos. Chama a atenção que em 1989 os empregos diretos eram 6.058, duas vezes mais que hoje e que desde que se iniciou a contar os indiretos em 1997, o número passou de 3.706 para quase a metade (DAVID, 2006).

No extremo sul, do Estado da Bahia, na cidade de Guaratinga, a prefeitura do município tomou a decisão inédita de limitar o plantio de eucalipto na região devido aos altos índices de desemprego gerados pelas empresas florestais que ocupam as terras para o plantio de eucalipto.

Em levantamento realizado pela prefeitura, em cada fazenda, ficam desempregadas cerca de 40 pessoas que trabalhavam direta ou indiretamente. O dinheiro oferecido pelas empresas para os donos da área é de aproximadamente cinco ou dez mil reais. Com ele os produtores rurais compram uma casa na cidade, e cerca de três meses depois estão passando necessidades. (PINTO, 2011) 
Outra questão é a exploração da mão de obra nas carvoarias muitas vezes chega a situações extremas, corriqueiramente havendo a manutenção de trabalhadores em situações análogas à escravidão. Muitas carvoarias inclusive foram incluídas na "Lista Suja" do Ministério do Trabalho e Emprego (MTE) (OIT, 2007).

A produção de carvão, na região do Carajás, como retrata (MONTEIRO, 2006):

"a produção de carvão reproduz mecanismos de superexploração da força de trabalho; amplia a pressão sobre a floresta; reforça as tensões sociais no campo e apesar de estar presente no discurso oficial como um dos elementos de uma pretensa racionalidade econômica modernizante é nitidamente conservadora, porquanto não se dissocia do latifúndio”.

O Ministério Público do Trabalho fiscaliza mais efetivamente o setor desde 1999 quando celebrou Termo de Ajustamento de Conduta com várias siderúrgicas brasileiras na tentativa de reverter o quadro de exploração da mão-de-obra nesses ambientes.

Entretanto, os mesmos não lograram êxito e começaram sucessivas autuações por parte do órgão governamental em relação as siderúrgicas. Situação mais crítica observou-se no norte do país.

Dessa forma, os empregos de carvoaria são de péssima qualidade, pois as condições de trabalho, moradia e estabilidade no emprego não têm níveis satisfatórios. Segundo, o autor o emprego (MONTEIRO, 1994):

"Não contam com garantias previdenciárias e trabalhistas, a remuneração mensal dificilmente ultrapassa o salário mínimo nacional, além do que estão sujeitos a mecanismos coercitivos de imobilização da força de trabalho".

Apesar da geração de empregos no setor, a remuneração percebida não modifica o perfil de renda da população contribuindo com a baixa qualidade de vida do empregado e sua família e a manutenção da concentração fundiária na região. 
Em algumas regiões do país como no Maranhão constatou-se diversas irregularidades nas carvoarias dentre elas o alojamento dos trabalhadores, em que em 9,3\% delas não havia cobertura (teto) ou era feita de lona; das instalações sanitárias que eram inexistentes ou apresentaram falta de privacidade em $22 \%$ dos locais verificados e, $20 \%$ da água potável à disposição dos trabalhadores não existia ou estava em acondicionamento inadequado (SALES \& DALMOLIN, 2008).

Ainda, o relatório mostra outros aspectos de ilegalidade e exploração da mão-de-obra como a retenção salarial (uma das situações que caracteriza o trabalho escravo), inadimplência quanto aos encargos sociais e salariais, sobre a produtividade, bem como a exploração do trabalho de crianças e adolescentes nas carvoarias a inexistência de exames médicos, falta de recolhimento de encargos trabalhistas e ausência de registro de emprego.

Outros exemplos de carvoarias que infringem as normas trabalhistas encontram-se no estado de Minas Gerais. Nesses ambientes são encontradas crianças que com pouca idade, por volta dos 6 a 7 anos conhecem todo o processo da produção de carvão, bem como se responsabilizam pelas etapas de carvoejamento. Os trabalhadores se alojam próximos aos fornos, em instalações improvisadas, cobertas por lonas, dormindo em catres e não dispõem de condições mínimas de higiene e saneamento básico (DIAS, 2002).

De todo o processo de produção de carvão vegetal, a etapa mais crítica que é a retirada do produto dos fornos, nessa fase, o trabalhador está mais exposto a altas temperaturas e aos gases da combustão da madeira, sob exigência de esforços físicos importantes (DIAS, 2002).

No tocante a concentração fundiária, novamente retoma-se para análise o exemplo do cerrado brasileiro. Esse bioma é extremamente rico em diversidade biológica, bem como cultural, vem se transformando numa área de expansão de grandes latifúndios produtivos pelas “enormes vantagens" oferecidas pela indústria do agronegócio.

Entretanto, destaque-se que tal vantagem tem apenas um único beneficiado, qual seja, a indústria. Estudo realizado por (PORTO GONÇALVES, 2006) ressalta a questão da utilização 
da expressão deserto verde, não apenas no tocante ao recurso hídrico, mas sim na expansão da monocultura de eucalipto:

“(...) compelidos pela exiguidade de terras, os camponeses se vêem obrigados a fazer uso dos recursos naturais com técnicas que desenvolveram e estavam adaptadas a terras disponíveis em grande extensão. Os camponeses do cerrado, se vêem, hoje, desapropriados por um modelo que, por sua própria lógica, não democratiza seus benefícios, seja pela elevada magnitude de capital que exige a acender a todo o pacote tecnológico; seja pelas enormes extensões de terras; seja, ainda, pela diminuição de preços agrícolas que provoca, impedindo que cheguem ao mercado aqueles que estão abaixo do nível de produtividade médio, sempre rebaixado pelas grandes empresas do agronegócio. Por sua vez, esse modelo transfere para a sociedade como um todo e até mesmo para gerações futuras sua enorme ineficiência energética global e seus danos ambientais diversos."

$5.3 \mathrm{O}$ aterro sanitário

No aspecto específico do aterro sanitário podemos chamar atenção para alguns passivos ambientais:

A. Poluição Sonora e Atmosférica;

B. Alteração da paisagem local e mudança na rotina dos moradores do entorno ao empreendimento;

C. Surgimento e proliferação de insetos e roedores e mau cheiro exalado pelos resíduos;

D. Risco a contaminação das águas;

E. Desvalorização dos terrenos no entorno do empreendimento. 


\section{A. Poluição Sonora e Atmosférica.}

A poluição sonora e atmosférica dos aterros sanitários se deve a movimentação do maquinário do aterro como tratores, retroescavadeiras e caminhões que circulam diuturnamente pelas unidades operacionais dos aterros sanitários.

Portanto, a poluição sonora advém do inúmero trânsito de carretas nas unidades de tratamento que possuem motores com alto poder impactante de ruídos, além é claro, de seu deslocamento levantar e dispersar a poeira das estradas e locais de acesso dos aterros que são de terra batida.

Assim o material particulado se dispersa para áreas em torno do empreendimento gerando incômodo e transtornos, principalmente irritação ocular e problemas nas vias respiratórias, principalmente de crianças e idosos.

\section{B. Alteração da paisagem local e mudança na rotina dos moradores do entorno ao empreendimento.}

Nessa seara chama-se a atenção para a descaracterização da área onde se instala o empreendimento do aterro sanitário. Qualquer obra de engenharia é motivo, por si só, pela a descaraterização de um ambiente, ainda mais tratando-se de um projeto grandioso como a construção de um aterro sanitário.

Evidente que o aterro sanitário é uma obra que causa um impacto no entorno em qualquer local ou situação que for instalado. Entretanto, a cidade de São Paulo, tendo aumentado sua população e consequentemente seu resíduo carece de estações de tratamento de seu lixo e necessita de áreas em seu entorno para a destinação adequada desse material que diariamente é produzido por seus habitantes. 
Isso altera sem dúvida alguma o cotidiano dos moradores que residem no local de instalação do empreendimento sanitário. No caso específico do aterro Bandeirantes, esse incômodo se estendia a pelo menos 120 mil habitantes da comunidade local que em sua grande maioria conviviam além do transtorno do aterro com a miséria e a falta de infraestrutura.

\section{Surgimento e proliferação de insetos e roedores e mau cheiro exalado pelos resíduos.}

Por mais que se tenha um controle rígido com relação a insetos e roedores em um aterro sanitário seria impossível eliminar esses tipos de animais de uma localidade que abriga uma quantidade de lixo significativa.

Além do mais, os resíduos além de serem propícios ao desenvolvimento desses animais muitas vezes os mesmos são transportados aos aterros o que praticamente impossibilita a eliminação total desses animais.

A técnica central do aterro sanitário consiste em aterrar os resíduos de forma a acondiciona-los no solo, sob cobertura de terra e tratamento dos percolados, por meio de drenos de chorume, bem como de drenos de gás.

O odor é característico do lixo em decomposição, mais precisamente do material orgânico em putrefação. Por mais que se criem barreiras de contenção para que esse odor fique no local de operação do empreendimento, ou que se aumente a velocidade da operação de aterramento o odor se dissipa devido a mudança da direção dos ventos, a alteração de temperatura, bem como a própria movimentação das carretas que levam o resíduo, em fase já avançada de putrefação, aos aterros sanitários.

\section{Risco a contaminação das águas}


Talvez esse seja a motivo mais crítico da implantação e operação de um aterro sanitário, o controle constante e a impermeabilização do mesmo para que não haja contaminação do lençol freático ou qualquer outro corpo d’água no entorno desses empreendimentos.

As técnicas de impermeabilização do aterro vão desde a utilização de tecidos sintéticos conhecidos como geomembranas, o encapsulamento de lençóis freáticos que estejam na áreade operação do empreendimento, o controle das águas pluviais e o monitoramento dos níveis de contaminação nos corpos d’ água.

Apesar de todas as técnicas utilizadas hoje estarem dentro de uma margem de segurança com alto grau de aceitação pela comunidade científica riscos são sempre possíveis, uma vez que todas essas implantações dependem da seriedade com que são introduzidas, instaladas e monitorada por parte dos agentes que as conduzem.

\section{E. Desvalorização dos terrenos no entorno do empreendimento}

Essa constatação não é apenas evidente para os moradores do entorno da região de instalação do empreendimento, mas é sentida por meio do reflexo do mercado imobiliário que é altamente especulativo e acompanha qualquer tipo de inovação, seja ela positiva, ou negativa, como no caso em tela.

Mais do que simples é a leitura de um empreendimento de aterro sanitário para o mercado de imóveis da região, a partir do momento do anúncio da possibilidade da instalação da obra o mercado reage com muito mau humor, pois é evidente que um futuro comprador de um imóvel localizado na região quer ter como vizinho um empreendimento com as características anteriores descritas.

No caso específico do empreendimento em estudo a operação do aterro na recepção dos resíduos está desativadas desde 2007, o que faz com que essa desvalorização seja revertida com o passar dos anos. 


\subsection{Serviço Ambiental Prestado}

Mecanismos de compensação e prêmios pela conservação e restauração de serviços ambientais podem ser importantes instrumentos para a promoção da sustentabilidade social, ambiental e econômica. Esses mecanismos podem servir como veículos para a geração dos meios e serviços necessários a uma qualidade de vida digna e sadia (BORN e TALOCCHI, 2002).

Instrumento de Compensação ou Prêmios por Serviços Ambientais tem como principal objetivo transferir recursos ou benefícios da parte que se beneficia para a parte que "ajuda" a natureza a produzir ou manter os seres vivos e as condições que garantem os processos ecológicos que necessitamos (BORN e TALOCCHI, 2002).

A prestação do serviço ambiental não está relacionada única e exclusivamente a interesses de um dos agentes do processo. Nesse sentido considerar o sequestro de carbono como categoria exclusiva de promoção da sustentabilidade seria um grande equívoco.

Equívoco esse que vem sendo cometido por inúmeras corporações do setor siderúrgico e de celulose que veem exclusivamente a obtenção de créditos de carbono como um elemento econômico financiador da sustentabilidade. Na verdade, o carbono sequestrado não é elemento suficiente, por si só, para a promoção da sustentabilidade.

Assim para que exista o direito de recebimento de um serviço ambiental prestado é necessário que a atitude daquele que o pleiteia esteja além da preservação da natureza, pois este último é obrigatoriedade de todos os cidadãos e pessoas jurídicas desse país.

Dessa forma se uma atitude individual ou coletiva vier a gerar um benefício coletivo e não apenas privado, ai sim, se justificaria a adoção de algum mecanismo para premiar aquele que realiza algo a mais que a média (BORN e TALOCCHI, 2002). 
Muitos técnicos têm falado que um dos benefícios da silvicultura será a captura de carbono e a contribuição para diminuir o aquecimento global. Porém, isto é uma forma de manipulação da opinião pública, pois omitem o restante da informação: ao cortarem estas árvores e realizarem o processo de industrialização da celulose até a obtenção do papel, este carbono será novamente emitido para a atmosfera.

Esta é a principal forma de aumento de gás carbônico contribuinte para o aquecimento global, que será proporcionada pelos empreendimentos de silvicultura baseada na produção de celulose.

Eticamente, o plantio de árvores somente pode ser contabilizado para a diminuição do aquecimento global se estivermos falando de árvores que serão plantadas e serão preservadas intocáveis, contribuindo efetivamente para a captura do gás carbônico presente na atmosfera. Sabe-se, entretanto, que esta não é a realidade da maioria dos projetos de silvicultura, não sendo diferente o projeto analisado nessa pesquisa.

Nesse tópico da pesquisa far-se-á uma análise comparativa entre os serviços ambientais prestados entre um projeto de silvicultura e a utilização do biogás de um aterro sanitário já desativado.

No tocante a silvicultura tem-se uma produção de eucalipto voltada para diferentes setores, dentre os destaques para o setor siderúrgico pela utilização do carvão vegetal e o setor de papel e celulose.

Dessa forma estamos falando de um ciclo vegetal de três anos para o setor de carvão vegetal e sete anos para o setor de papel e celulose. Em ambos, não se tem compensação ambiental pelo carbono sequestrado, haja vista, que o ciclo do carbono por completa se finda em vinte anos ou até mais e tais árvores são consumidas em tempo muito mais resumidos do que esse. 
Dai se retira a primeira indagação desse fato: o sequestro de carbono segue qual lógica de análise? A obtenção de créditos de carbono não contabiliza nesse cálculo que tais vegetais serão novamente inseridos no processo produtivo, antes mesmos, que consigam fixar o carbono no solo?

Outra análise que precisa ser necessariamente realizada é a diferenciação entre reflorestamento e florestamento que passa muitas vezes desapercebidas pela grande massa populacional e é objeto de atenção desses grandes complexos siderúrgicos e da indústria papeleira.

O reflorestamento é a implantação de florestas em áreas naturalmente florestais, ou seja, deve ser feito não apenas com o plantio de árvores, mas uma mistura de todas as espécies da região.

O florestamento é a implantação de florestas em áreas que não eram florestadas naturalmente. Deve-se ter o cuidado de ressaltar que a silvicultura quando implantada em áreas que antes não possuíam florestas substituem a vegetação nativa por uma floresta homogênea, o que veem sendo, paulatinamente, destacado no corpo dessa pesquisa.

Destaca o emérito professor e geógrafo (AB’SABER, 2012) mostrando sua indignação pelos defensores de liberalizações do Código Florestal Brasileiro:

"Os relatores do Código Florestal falam que as áreas muito desmatadas e degradadas poderiam ficar sujeitas a “(re)florestamento” por espécies homogêneas pensando em eucalipto e pinus. Uma prova de sua grande ignorância, pois não sabem a menor diferença entre reflorestamento e florestamento. Esse último, pretendido por eles, é um fato exclusivamente de interesse econômico empresarial, que infelizmente não pretende preservar biodiversidades. (...) Os eucaliptólogos perdem sentido ético quando alugam espaços por trinta anos de incautos proprietários, preferindo áreas dotadas ainda de solos tropicais férteis, do tipo dos oxissolos, e evitando as áreas degradadas de morros pelados reduzidas a trilhas de pisoteio, hipsométricas, semelhantes ao protótipo 
existente no Planalto do Alto Paraíba, em São Paulo. Isso ao arrendar terras de bisonhos proprietários, para uso em 30 anos, e sabendo que os donos da terra podem morrer quando se completar o prazo. Fato que cria um grande problema judicial para os herdeiros, sendo que ao fim de uma negociação as empresas cortam todas as árvores de eucaliptos ou pinus, deixando miríades de troncos no chão do espaço terrestre. Um cenário que impede a posterior reutilização das terras para atividades agrárias. Tudo isso deveria ser conhecido por aqueles que defendem ferozmente um Código Florestal liberalizante."

Nesse sentido o que se tem visto é que a implantação da silvicultura privilegia o florestamento de áreas novas ou até mesmo expandido para áreas com mata nativa e competindo, infelizmente, em muitos casos com essas.

Surge, portanto, a partir da leitura de tal fato a segunda indagação: se o estabelecimento da monocultura é uma atividade que não privilegia a biodiversidade como pode esta ser reconhecida como mecanismo de desenvolvimento limpo e, por conseguinte, ser merecedora da obtenção de crédito de carbono por parte das empresas?

A indagação nos chama a atenção da questão da análise do serviço ambiental prestado. Conforme discutido anteriormente é nítido que tal serviço não é prestado, ou se o fosse, não seria por completo, uma vez que atende a interesses econômicos, única e exclusivamente, de complexos corporativos dos setores siderúrgicos e de papel e celulose.

O que chama atenção de toda essa problemática é que o pequeno e médio proprietário que pratica uma agricultura tradicional conservando e preservando os espaços naturais não é contemplado dentre dessa ótica de análise, pois os assim chamados mecanismos de desenvolvimento limpo, não elegem os verdadeiros sequestradores de carbono, ou seja, aqueles que nunca desmataram e sempre mantiveram a vegetação original de pé, mas sim grandes corporações que historicamente sempre foram poluidores e os grandes responsáveis por grandes impactos ambientais. 
Não há que se falar, portanto, em serviço ambiental prestado por parte dos grandes grupos implantadores da atividade monocultura de silvicultura. A falsa alegação de sequestro de carbono deve ser mais amplamente observada, pois o que há, na verdade, é um descaso com a biodiversidade de vários biomas brasileiros, no caso específico dessa pesquisa o cerrado.

Outro ponto de análise que caracteriza a falta do serviço ambiental prestado é a questão social das comunidades tradicionais no que diz respeito a geração de novos empregos e a consequente expropriação dos pequenos e médios agricultores.

Nesse contexto destaca-se a política agrícola e de financiamento rural brasileira vinculada a um modelo de desenvolvimento que tem como um de seus pressupostos básicos a viabilização de um processo de modernização, que visa ao aumento da produção e produtividade agropecuária, à integração do setor à indústria e ao mercado externo, e à diminuição do pessoal ocupado, mediante o controle das condições naturais pela intensificação do uso de insumos químicos, maquinários e implementos agrícolas, previstos no "pacote" tecnológico da Revolução Verde (TURA e MATTOS, 2002).

Nessa perspectiva, o "atraso" tecnológico e a heterogeneidade socioambiental são tidos como obstáculos à formação e expansão da produção capitalista, cabendo à extensão rural a difusão e transferência de tecnologias "modernas", tendo como principal instrumento financeiro o crédito rural. (TURA e MATTOS, 2002)

Cabe ser ressaltado que muitos desses projetos e financiamentos para serem aprovados necessitam de orientações técnicas que não se dirigem nem à produção familiar rural, nem à preservação ambiental, mas aos grandes monocultivos voltados para a maximização dos resultados econômicos, com o uso intensivo de insumos químicos. A heterogeneidade dos ecossistemas regionais foi subordinada à meta política de resultados homogeneizadores, negando a tradição familiar rural de polivalência. Em sua maioria, os projetos financiados foram elaborados no escritório, sem a participação dos produtores, e de forma padronizada. Como consequência, não condiziam, necessariamente, com a disponibilidade de mão-de-obra, 
com os recursos naturais existentes, com a experiência acumulada do produtor, com os canais de comercialização e infraestrutura disponíveis e com o calendário agrícola regional, causando distorções técnicas e econômicas nos projetos e reduzindo os cultivos a sistemas simplificados, rompendo com as condições de complexidade, estabilidade e biodiversidade predominantes nos ecossistemas naturais e diminuindo sua capacidade de suportar impactos ambientais. (TURA e MATTOS, 2002)

O exemplo amazônico trazido pelos autores se estende, em muitos aspectos, as características do cerrado mineiro. Não é diferente a situação da implantação de grandes complexos de monocultura de silvicultura que são quase em sua totalidade financiado a juros muito abaixo de mercado pelo BNDES.

Ainda, todo esse financiamento que tem pelos órgãos governamentais um discurso desenvolvimentista, cumpre na verdade, a algo historicamente conhecido pela população brasileira, desde os tempos de colonização, intitulado "sistema plantation", onde se tem uma grande produtividade de uma determinada matéria prima, realizada por uma mão de obra escrava, ou extremamente barata, visando a exportação ou ao mercado externo. Na realidade, talvez a única mudança esteja no fato de que hoje as grandes corporações estejam instaladas no país para realizarem o beneficiamento da matéria prima e enviar o resultado desse beneficiamento, qual seja, o produto final para o mercado internacional.

Temos dessa forma, o seguinte cenário: incentivo governamental em desenvolvimento da monocultura de silvicultura em detrimento do abandono da pequena propriedade rural ou culturas tradicionais que são paulatinamente expropriadas pelo aumento da demanda do setor de ferro-gusa e papeleiro na região de estudo.

A expropriação de terras é nitidamente verificada na região, pois novas áreas vão sendo tomadas para o cultivo dessa monocultura e não se tem contrapartida uma "compensação social" dessa situação. Ou seja, o resultado é algo muito conhecido do mundo nos últimos quarenta 
anos, aumento dos grandes latifúndios monocultores em detrimento da escassez de alimentos e aumento da pobreza no mundo.

Dessa forma, o que se tem é um aumento do desemprego no setor, que mesmo quando o mercado encontra-se aquecido, emprega abaixo de suas promessas para conquistar financiamentos e aprovações para novos cultivos.

A Tabela 13 abaixo retrata a situação do desemprego de Curvelo, um dos municípios, onde se encontra a indústria objeto desta pesquisa.

Tabela 13: Flutuação do emprego formal do município de Curvelo- Jan/ 2009 à jun/ 2009.

\begin{tabular}{llll}
\hline ATIVIDADES & ADMITIDOS & DESLIGADOS & SALDO \\
\hline Extrativa Mineral & 25 & 30 & $(-5)$ \\
$\begin{array}{l}\text { Indústria de } \\
\text { Transformação }\end{array}$ & 327 & 305 & 22 \\
Construção Civil & 803 & & \\
Comércio & 673 & 459 & 344 \\
Serviços & 626 & 642 & 31 \\
Agropecuária & 1065 & 710 & $(-84)$ \\
Total Atividades & 3519 & 2257 & $(-1192)$ \\
\hline Fonte: CAGED/MTE & & 4403 & $(-884)$ \\
\hline
\end{tabular}

Cabe ser observado que a agropecuária foi o setor que mais reduziu postos de trabalho e que essa atividade tem participação muito expressiva a empresa objeto dessa pesquisa. Além da questão de mercado, como afirmado anteriormente, existe uma tendência cada vez mais crescente da redução de postos de trabalho devido ao implemento de maquinário e modernização da produção o que é um dos grandes responsáveis pela diminuição do emprego no setor.

A tabela 14 demonstrada a seguir comprova a tendência de redução do emprego no setor agropecuário, pois retrata uma realidade não somente a região do estudo mais a todo o Estado de Minas Gerais. 
Tabela 14: Variação dos índices de emprego - Minas Gerais.

\begin{tabular}{l|r|r|c}
\hline \multirow{2}{*}{$\begin{array}{c}\text { Setores de Atividade } \\
\text { Econômica }\end{array}$} & \multicolumn{2}{|c|}{ Saldo de Dezembro de 2011 } & $\mathbf{2 0 1 1}$ \\
\cline { 2 - 4 } & Variação Abs oluta & Variação Relativa (\%) & Variação Absoluta \\
\hline Extrativa Mineral & -25 & $-0,04$ & 5.325 \\
Indústria de Trans formação & -17.132 & $-1,99$ & 26.015 \\
SIUP & -111 & $-0,32$ & 360 \\
Construção Civil & -16.553 & $-4,82$ & 13.965 \\
Comércio & 1.226 & 0,14 & 47.170 \\
Serviços & -8.388 & $-0,56$ & 103.923 \\
Administração Pública & -946 & $-1,31$ & 2.361 \\
Agropecuária & -9.564 & $-3,37$ & 7.283 \\
\hline Total & $-\mathbf{5 1 . 4 9 3}$ & $\mathbf{- 1 , 2 8}$ & $\mathbf{2 0 6 . 4 0 2}$ \\
Fonte: Caged, Lei 4.923/65. & \multicolumn{3}{|c}{} \\
Nota: No cálculo do saldo acumulado de 2011 estão considerados os dados de declarações recebidas fora do prazo de janeiro a novembro 2011.
\end{tabular}

Perceptível que a agropecuária é um dos setores que apresenta maior redução de empregos na variação relativa, demonstrando a tendência de redução dos postos de trabalho no setor.

Por fim se faz a terceira e última indagação pelos fatos apresentados: se essa monocultura é exploratória, ambientalmente e socialmente, qual o sentido de se beneficiar algo que contraditoriamente é impactante nas populações e biomas locais?

No que diz respeito à obtenção de créditos de carbono em relação à transformação de gases metano em biogás se passa a analisar a situação fática.

Necessário, em primeiro momento, destacar que o aterro sanitário Bandeirantes é um empreendimento inoperante para o recebimento de resíduos desde 2007. O objeto dessa pesquisa não é comparar as atividades propriamente ditas, mas sim seus ganhos ambientais reais.

Dessa maneira, não se defende aqui a técnica de aterro sanitário em detrimento de outras, mesmo porque, sabe-se que o problema dos resíduos urbanos é de uma complexidade extrema e indubitavelmente necessita de uma gestão que passa por mais de uma técnica de engenharia para sua solução. 
Aliás, até pela característica dos resíduos urbanos no Brasil possuírem em sua composição cerca de $60 \%$ de material orgânico, o aterramento não seria a técnica mais adequada para o recebimento desse tipo de material, pois seria um grande desperdício de espaço, mas sim a compostagem desses resíduos que poderia oferecer um retorno a natureza em forma de adubo ou, no mínimo, regulador de solo.

Sabe-se que a concentração de metano teve um acréscimo em 1060 ppb (partes por bilhão) desde 1750 . Tal dado representa um aumento de $151 \%$ do total de emissões de metano no mundo, mais da metade é de origem antropogênica (aterros sanitários, agricultura de arroz, combustíveis fósseis e gado). Os aterros podem produzir de 6 a $20 \%$ desse total de metano (IPCC, 1996). Portanto, o aproveitamento do gás produzido em aterros é uma opção convidativa para a redução de gases do efeito estufa.

Os aterros sanitários são uma das maiores emissões de metano no mundo. O gás de aterro é produzido pela decomposição anaeróbica (sem a presença de oxigênio) de resíduos orgânicos. Este gás é composto por aproximadamente $50 \%$ de metano (CH4), 40\% de dióxido de carbono (CO2), 9\% de nitrogênio, e concentrações residuais de compostos orgânicos voláteis, poluentes perigosos e outros elementos. Ressalte-se que o metano tem um potencial de aquecimento global 21 vezes superior ao do dióxido de carbono (SILVA e CAMPOS, 2008).

O que se tem, portanto, é um empreendimento inoperante que recebeu durante sua operação desde 1979 a março de 2007 uma quantidade aproximada de 40 milhões de toneladas de resíduos. Cada tonelada de resíduo depositado em aterros sanitários gera em média 200 metros cúbicos de biogás. Em 2004, as reservas de gás metano foram estimadas em 2,4 bilhões de $\mathrm{m}^{3}$ de biogás. (MELLIS, 2004).

A usina entrou em operação em dezembro de 2003. Em setembro de 2007, o projeto viabilizou a venda por meio de leilão de créditos de carbono via bolsa de valores de 808.405 créditos de carbono da prefeitura de São Paulo acumulados pelo projeto Usina Termelétrica 
Bandeirantes até a data do evento, arrecadando mais de $\mathrm{R} \$ 34$ milhões para o poder público (ITAÚ UNIBANCO HOLDING AS, 2006).

A energia produzida na Usina Termoelétrica Bandeirantes pode chegar a 20 MW médios, o suficiente para abastecer uma cidade com 400 mil habitantes durante dez anos (ITAÚ UNIBANCO HOLDING AS, 2006).

Cabe ser ressaltado que com o fim das operações de recebimento de resíduos por parte do aterro sanitário a área se tornou um grande espaço aberto sem destinação. A população local no momento desde a desativação do aterro foi favorável à construção de um parque na localidade.

Entretanto, como ressaltado anteriormente, houve a opção para a instalação da usina termelétrica para a exploração do biogás e consequentemente a venda dos créditos de carbono. Importante se ressaltar que, sem sombra de dúvida, o grande beneficiário dessa instalação foi a corporação bancária e as grandes corporações a frente do negócio.

Numa análise primordial, poderia ser feita a comparação anteriormente tecida em relação a monocultura da silvicultura no outro projeto dessa pesquisa, demonstrado que os únicos beneficiários são as grandes corporações que coordenam os projetos.

Mas é necessário demonstrar a seguinte realidade fática. Independente da comparação do sequestro de carbono realizado em ambos projetos, algo que a presente pesquisa não tem a pretensão de vislumbrar, o fato de se converter a área em um parque, não haveria a possibilidade de gerar o montante de receita tanto para a iniciativa privada, como para esfera pública.

Ressalte-se dessa forma que a comercialização dos créditos trouxe para esse grande espaço sem utilização uma grande quantidade de capital que foi investido no entorno melhorando as condições de vida da população local. Note-se que a opção pela instalação, num primeiro momento, padeceria de demais investimentos futuros, que pela experiência da governança brasileira, infelizmente não seriam feitos. 
Foram realizados investimentos na rede básica de distribuição de energia que antes apresentava instabilidade no fornecimento. As ligações clandestinas, comumente chamadas de "gatos", que eram habituais na região antes da instalação da usina, foram substituídas por conexões em conformidade com padrões técnicos nacionais, aumentando a qualidade dos serviços de energia e principalmente a segurança dos usuários (ITAÚ UNIBANCO HOLDING AS, 2006).

A produção de créditos de carbono, estimada em 7,3 milhões de toneladas até 2015 (ITAÚ UNIBANCO HOLDING AS, 2006) irão gerar receita para o poder público, novamente, uma vez que metade dos créditos de carbono será destinada à Secretaria do Verde e do Meio Ambiente do município que deverão, necessariamente, em parte, ser utilizado na região do entorno do aterro sanitário.

Alguns projetos sociais começam a ser desenvolvidos na região, bem como a melhoria na infraestrutura de urbanização como centro de formações socioambiental, ciclovias, estações de recebimento de resíduos (coletas seletiva) denominadas ecopontos, reurbanização de avenidas e logradouros, recuperação de bacias hidrográficas, construção de praças e centros de convivência comunitários.

Por fim, o que se quer demonstrar aqui é que o fato da exploração de um aterro inativo por parte da inciativa público-privada, bem como a obtenção de créditos de carbono, gera um capital, que em parte, é aplicado no entorno e caso a atividade não existisse, teríamos apenas uma área de proporções significativas sem uso específico e muito provavelmente esquecida, uma vez que não haveria possibilidade de outro uso, senão um parque, uma vez que tal espaço possui um grande passivo ambiental.

Dessa forma a utilização desse capital obtido com a venda dos créditos de carbono é uma forma de minimizar os impactos sofridos pela população do entorno.

Evidente, portanto, que os dois projetos que obtiveram renda por meio da venda de créditos de carbono prestam serviços ambientais diferenciados, haja vista a monocultura de 
eucalipto ser expansiva, ou seja demanda novas áreas, invade e compete com a mata nativa dos locais onde se instala, aniquila e reduz a biodiversidade dos biomas, altera o balanço hídrico, é expropriatória (na medida que força os pequenos produtores rurais a deixarem suas terras) interfere nas relações sociais e de trabalho (tendo em vista a diminuição dos postos de trabalho, exploração da mão de obra e aniquilação de costumes locais). 


\section{CONSIDERAÇÕES FINAIS E RESULTADOS}

O sistema produtivo linear com base na retirada de recursos naturais e queima de combustíveis fósseis como carvão e petróleo ocasiona uma série de impactos ambientais, uma vez que não respeita a capacidade de suporte dos recursos naturais, tanto na obtenção de matérias-primas, quanto no descarte dos resíduos no meio ambiente.

Tais impactos ocasionam perturbações nos ambientes de uma forma global, como nos recursos hídricos, solos, biomas entre outros. É nesse contexto que se estabelecem tratados internacionais como a Convenção do Clima e o Protocolo de Quioto com a finalidade de alcançar o desenvolvimento sustentável por meio do mecanismo de desenvolvimento limpo, denominado de MDL.

Projetos do MDL geram a possibilidade de trazer uma grande quantidade de benefícios de ordem local e regional. Isso inclui benefícios ambientais, sociais e econômicos como água e ar mais limpos, geração de empregos, redução da pobreza, diminuição do desmatamento e da perda da biodiversidade, aporte de capital estrangeiro, e o acesso a tecnologias "verdes".

Os incentivos advindos dos MDL, com suas receitas advindas da comercialização dos créditos de carbono, representam uma importante fonte de recursos externos para promover o desenvolvimento limpo e sustentável.

Diante de tal realidade foram analisados dois projetos de MDL distintos. Duas situações bem distintas são verificadas. Primeiro, temos a monocultura de silvicultura que apesar de alguns pontos positivos é altamente favorecedora de uma concentração fundiária, em detrimento da utilização da terra pelas comunidades locais, exploração da mão de obra, bem como a contaminação do solo pelo uso intensivo de agrotóxicos e redução da biodiversidade.

Na realidade essa cultura é responsável pelo fracasso da melhor distribuição de renda e alimentos da Revolução Verde concebida nas décadas de 1960 e 1970. Evidente que tal 
fracasso, do ponto de vista social e humano, pois do ponto de vista do capital, ou do agronegócio ele é sem dúvida, uma das culturas de destaque no Brasil.

Dessa forma as grandes corporações envolvidas em megaprojetos de monocultura de silvicultura com a obtenção de recursos via MDL apresentam desenvolvimento e expansão econômica sob a alegação de sustentabilidade.

Realmente analisar o desenvolvimento sob a ótica estritamente do capital, as receitas obtidas pela venda dos créditos de carbono na monocultura de silvicultura são dignas de esforços para as corporações envolvidas. Mas os créditos obtidos via MDL, em sua essência, visam contemplar ações sustentáveis e devem contemplar, necessariamente, o desenvolvimento social e cultural de um determinado povo.

A segunda situação se tem aterro sanitário que encerrou suas operações de recebimento de resíduos tornando-se um grande espaço aberto sem destinação. A partir dessa realidade fática foi montada uma Usina Termelétrica para aproveitamento do biogás e obtenção dos créditos de carbono, via MDL.

Cabe ser ressaltado que tal iniciativa gerou um aporte de capital muito expressiva que em parte, é aplicado diretamente no entorno do empreendimento e caso a atividade não existisse, se teria apenas uma área de proporções significativas, sem uso específico e muito provavelmente esquecida, uma vez que não haveria possibilidade de outro uso, senão um parque, uma vez que tal espaço possui um grande passivo ambiental.

A utilização desse capital obtido com a venda dos créditos de carbono é uma forma de minimizar os impactos sofridos pela população do entorno desde o início das operações do aterro sanitário.

O capital obtido com a venda dos créditos compensou de melhor forma o passivo ambiental deixado à população, mesmo porque a área de aterro é infinitamente menor e não expansiva se comparada à área utilizada pela monocultura de silvicultura. 
Ambos os projetos obtiveram renda por meio da venda de créditos de carbono, mas prestaram serviços ambientais diferenciados, haja vista a monocultura de eucalipto ser expansiva, ou seja, demanda novas áreas, invade e compete com a mata nativa dos locais onde se instala, aniquila e reduz a biodiversidade dos biomas, altera o balanço hídrico, é expropriatória (na medida que força os pequenos produtores rurais a deixarem suas terras) interfere nas relações sociais e de trabalho (tendo em vista a diminuição dos postos de trabalho, exploração da mão de obra e aniquilação de costumes locais).

Importante se frisar que nenhum dos dois projetos atende ao objetivo de concorrer para a redução de emissões de carbono para a atmosfera. Ainda, ressalte-se que o ciclo do eucalipto em muitos casos, como na produção de carvão para a fabricação de ferro gusa, é muito curto, podendo chegar até três anos, o que não conseguiria reter o carbono no solo, visto que o ciclo desse gás na natureza é de pelo menos vinte anos.

No caso específico do aterro sanitário temos que a obtenção dos créditos se justifica, uma vez que caso não fosse realizada a conversão do gás metano em biogás, haveria uma emissão de metano para a atmosfera na ordem de vinte uma vezes maior que a própria queima deste gás, para transforma-lo em carbono. Logo, o que se tem é a transformação de um passivo ambiental em recurso energético e com uma minimização de emissões do gás carbônico para a atmosfera.

Dessa forma os MDL são instrumentos importantes para o estímulo da sustentabilidade, entretanto não podem ser financiadores de projetos que contrariem a sua própria essência e concepção, ou seja, a sustentabilidade. Devem ser, portanto, mecanismos que reproduzam um desenvolvimento racional baseado no tripé social, ambiental e econômico, não privilegiado este último, em detrimento dos dois primeiros. 


\section{ANEXO I - PROCEDIMENTOS PARA GERAÇÃO DAS REDUÇÕES CERTIFICADAS DE EMISSÕES - RCES}

A. Geração das Reduções Certificadas de Emissão - RCEs

Como ressaltado anteriormente a Decisão 17/CP.7 é a decisão que estabelece as regras de procedimentos para a plena implementação do artigo 12 do Protocolo de Quioto, ou seja, a implantação dos MDL(s).

Para que se possa entender os mecanismos do MDL são necessárias, prima face, o entendimento especial de dois critérios, quais sejam:

- Elegibilidade;

- Ciclo de projetos do MDL

A.1 Os critérios de elegibilidade

Os critérios de elegibilidade estão contidos no artigo 12.5 do Protocolo de Quioto:

“Art.12.5(...)

(a) Participação voluntária aprovada por cada Parte envolvida;

(b) Benefícios reais, mensuráveis e de longo prazo relacionados com a mitigação da mudança do clima, $e$

(c) Reduções de emissões que sejam adicionais as que ocorreriam na ausência da atividade certificada de projeto."(PROTOCOLO DE QUIOTO, 2005) 
"A participação voluntária aprovada por cada Parte envolvida” é o primeiro critério de elegibilidade e tem fundamento a soberania exercida por cada país membro, não há que se falar em imposição de projetos de MDL ou atividades a eles inerentes, sem que haja a aceitação da Parte em relação ao MDL.

Dessa forma país algum pode impor a outro a implementação de um projeto de MDL, ou de certa atividade inerente ao mesmo, independentemente de seu grau de desenvolvimento econômico. Em outras palavras, nenhum país desenvolvido poderá impor a um país em desenvolvimento a obrigatoriedade de implementar atividades de projetos de MDL ou viceversa (SABBAG, 2009).

De acordo com as normas estabelecidas nas Convenções das Partes, a participação em um projeto de MDL, necessariamente, deve ser voluntário. As Partes interessadas em participar do MDL devem, em primeiro lugar, designar uma autoridade nacional (DNA) que será responsável pela aprovação ou não dos projetos de MDL no país hospedeiro.

Na realidade a aceitação voluntária ocorre quando as Partes integrantes do projeto de MDL emitem um documento denominado Carta de Aprovação, autorizando os participantes do projeto nas atividades, atendendo, por conseguinte, o artigo 40 da Decisão 17 CP.7

Cada Parte, portanto, terá seu procedimento específico para a emissão da Carta de Aprovação.

No caso Brasileiro, o órgão responsável pela emissão da Carta de Autorização é o Ministério da Ciência e Tecnologia que é auxiliado pela Coordenação Geral de Mudanças Globais de Clima - CGMGC e pela Comissão Interministerial de Mudança Global do Clima CIMGC.

Com vistas a obter a aprovação das atividades de projeto no âmbito do Mecanismo de Desenvolvimento Limpo - MDL, seus proponentes nacionais deverão enviar à Secretaria 
Executiva da Comissão Interministerial, em versão impressa e eletrônica (com conteúdo idêntico), os seguintes documentos (MCT, 2008):

- Documento de Concepção de Projeto (em inglês e em português);

- Anexo III;

- Cartas-convite a comentários;

- Relatório de Validação (em inglês e em português);

- Declaração sobre responsável pela comunicação e dados para contato;

- Declaração sobre conformidade com a legislação ambiental;

- Declaração sobre conformidade com a legislação trabalhista;

- Declaração sobre a situação da Entidade Operacional Designada-EOD.

Os critérios dos "benefícios reais, mensuráveis e de longo prazo relacionados com a mitigação da mudança do clima", consistem na transcrição dos ideais do Protocolo de Quioto e da Convenção do Clima.

O MDL não seria instrumento eficaz de flexibilização econômica e proteção ambiental se não cumprisse esse critério, pois em nada atenderia para a mitigação dos efeitos adversos da mudança global do clima um instrumento que não reduzisse efetivamente as emissões de gases do efeito estufa ou removesse gás carbônico (SABAGG, 2009).

$\mathrm{Na}$ verdade só serão consideradas as reduções se atenderem os critérios de adicionalidade e estiverem abaixo do nível de emissão calculado como a linha base.

Ainda, analisando esse critério ressalte-se que longo prazo reflete o próprio tempo para a obtenção dos créditos de carbono que podem ser de sete anos, sendo renovável por idêntico período de tempo por até duas vezes, ou dez anos sem renovação de tempo, exceto os períodos diferenciados para projetos florestais. 
O critério de adicionalidade, expresso pelas "Reduções de emissões que sejam adicionais as que ocorreriam na ausência da atividade certificada de projeto" certamente é o de demonstração mais controversa e desafiadora quando da elaboração do Documento de Concepção do Projeto e do requerimento do registro ao Conselho Executivo, sendo o principal motivo pelo qual atividades de projeto costumam ter seu registro rejeitado pelo Conselho Executivo do MDL (SABAGG, 2009).

A Decisão 17/CP.7 definiu em seu artigo 43 e 44 respectivamente adicionalidade e linha de base (também conhecida como cenário de referência) da seguinte forma:

"Artigo 43. A atividade de projeto do MDL é adicional se reduzir as emissões antrópicas de gases de efeito estufa por fontes para níveis inferiores aos que teriam ocorrido na ausência da atividade de projeto do MDL registrada.

Artigo 44. A linha de base de uma atividade de projeto do MDL é o cenário que representa, de forma razoável, as emissões antrópicas de gases de efeito estufa por fontes que ocorreriam na ausência da atividade de projeto proposta A linha de base deve cobrir as emissões de todos os gases, setores e categorias de fontes listados no Anexo A que ocorram dentro do limite do projeto. Deve considerar-se que a linha de base representa, de forma razoável, as emissões antrópicas por fontes que ocorreriam na ausência da atividade de projeto proposta quando derivada com o uso de uma metodologia de linha de base mencionada nos parágrafos 37 e 38 acima."

Assim, um projeto de MDL será adicional quando sua implementação reduzir as emissões de GEE por certa fonte de emissão inferior a linha de base.

Por sua vez, linha de base é uma estimativa da quantidade de gases de efeito estufa GEE emitida por atividades econômicas e da sociedade. Exemplo: quantidade de gás metano $\mathrm{CH}_{4}$ emitida por um determinado aterro sanitário durante o ano de 2010. Ou seja, é a referência para 
calcular a redução das emissões de GEE quando implantado um projeto de MDL. A figura 5 mostra uma situação hipotética de redução de emissão de GEE com a metodologia de adicionalidade e linhas de base.

Necessário faz se aqui uma pequena constatação, a de que as linhas de base devem ser calculadas para cada projeto específico de MDL, sendo as respectivas metodologias aprovadas pelo Conselho Executivo do MDL, conforme previsão legal contida nos artigos 37 a 52 do referido documento.

A diferença entre as emissões da linha de base e as emissões verificadas após o início das atividades do projeto de MDL, incluindo as fugas, é chamada de adicionalidade. A Figura 6 expressa o conceito de adicionalidade de um MDL.

Figura 31: Exemplo de uma redução de GEE de um projeto de MDL em um aterro sanitário

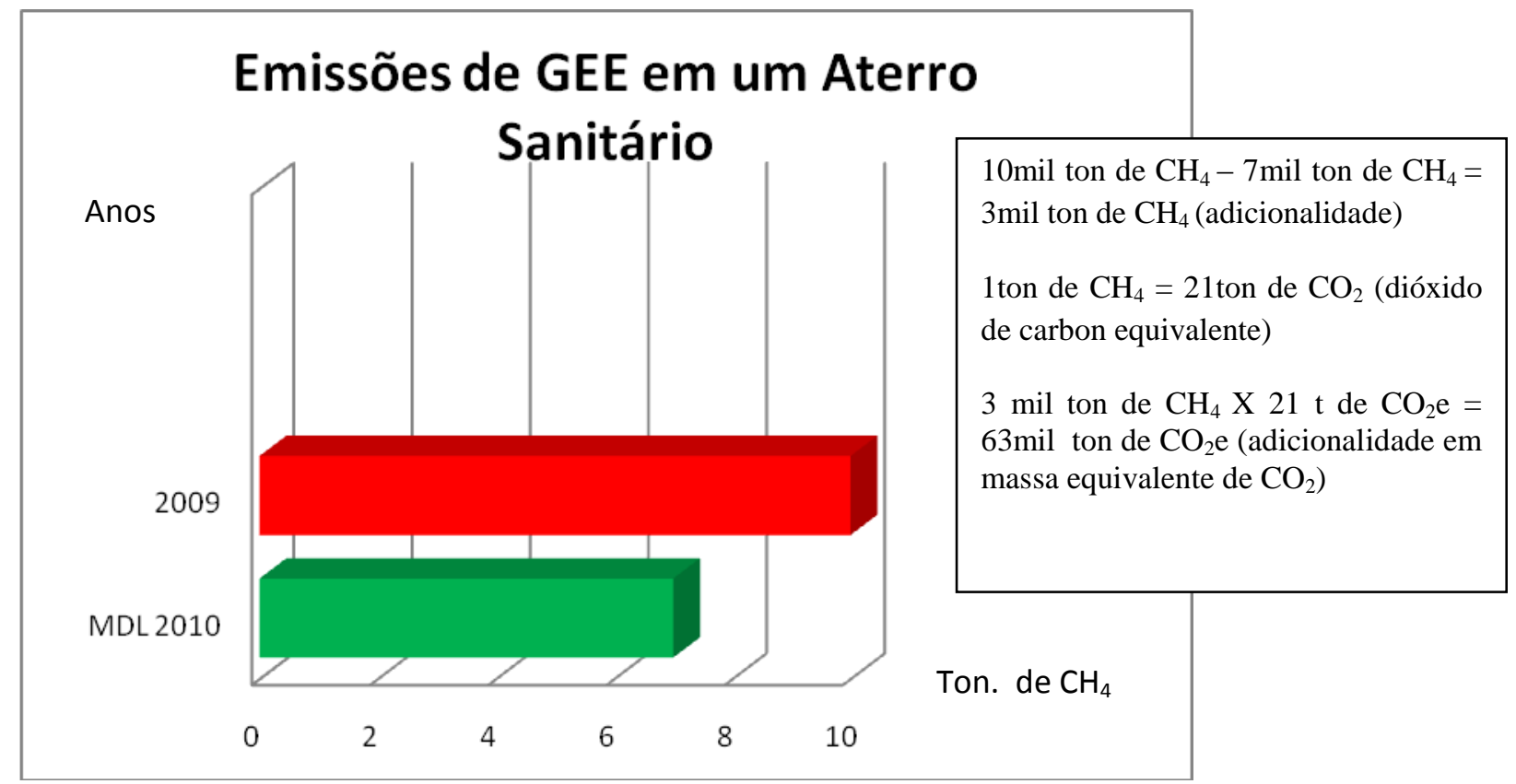

Fonte: Elaborado pelo autor 
Figura 32: Esquema para entendimento do conceito de adcionalidade

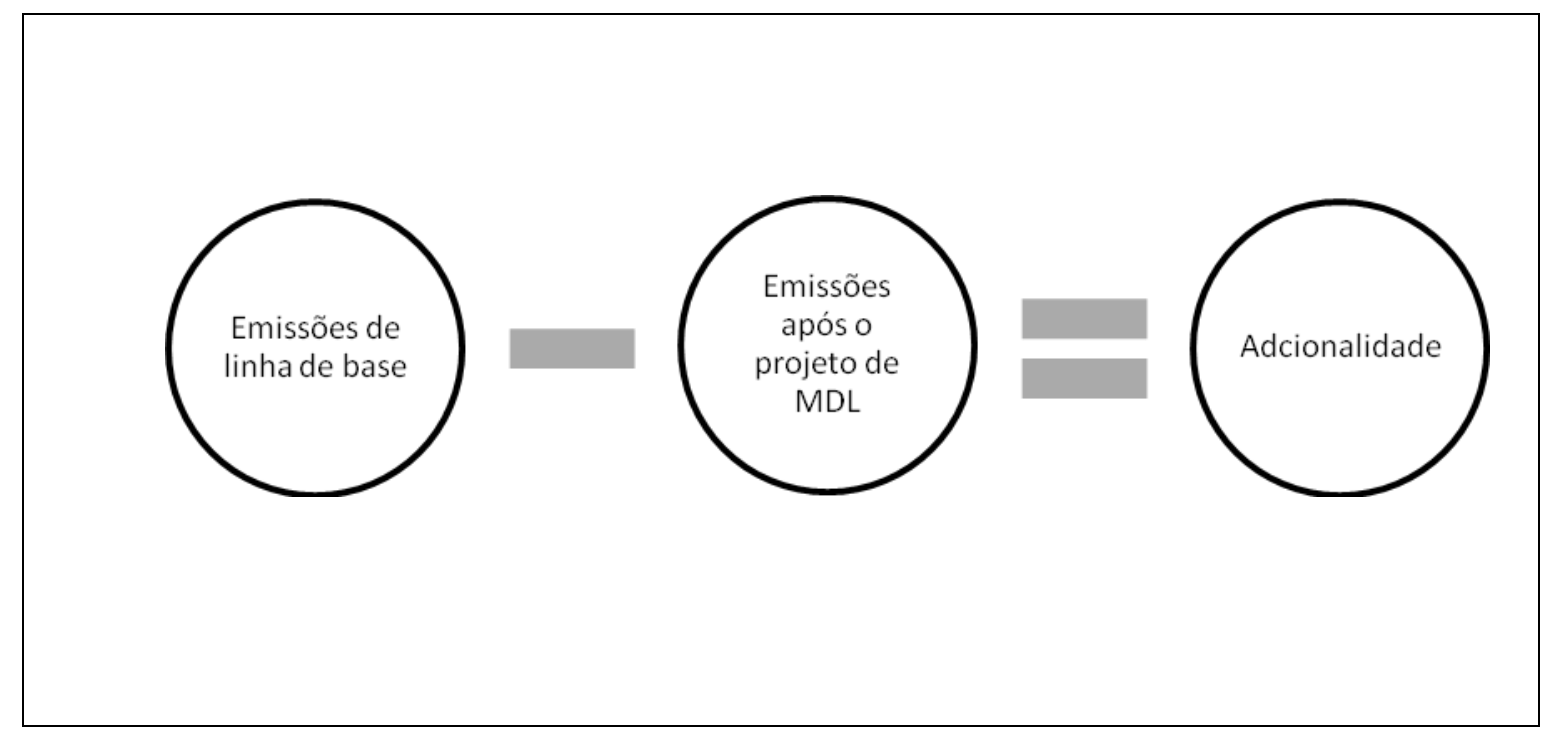

Fonte: o autor

Diante das dificuldades que os participantes dos projetos apresentaram para a comprovação da adicionalidade o Conselho Executivo publica o Tool for Demonstration and Assessment of Addiotionality que estabeleceu diretrizes para a comprovação do critério de adcionalidade (SABBAG, 2009).

De acordo com esse documento os participantes estão sujeitos a uma análise preliminar da atividade do projeto, devendo cumprir os seguintes requisitos:

- Identificação das alternativas ao projeto que cumpram as leis e as normas secundárias;

- Análise de investimentos (adicionalidade financeira);

- Análise das barreiras ao projeto;

- Análise do cenário comum de emissões; 
- Impacto do registro das atividades de projeto como um MDL.

O tool, ainda ressalta que o registro das atividades de projetos de MDL só seriam possíveis quando fosse comprovada que a exigência legal no país não é cumprida. (SABBAG, 2009).

Deve-se chamar atenção para atenção para análise do primeiro requisito preliminar trazido pelo tool. Nele temos a seguinte transcrição: "Identificação das alternativas ao projeto que cumpram as leis e as normas secundárias". Tal exigência poderia levar as seguintes interpretações:

Primeira, de que o projeto de MDL não pode estar acima das leis ambientais do país, uma vez que se as exigências legais, no tocante a seara ambiental, fossem desconsideradas, haveria uma inconformidade com a intenção da própria Convenção do Clima e o Protocolo de Quito, que exigem a publicação de leis mais restritas na área ambiental, em particular em relação aos efeitos no clima global (SABBAG, 2009).

Segunda, inviabilizar um incentivo financeiro ambiental sob a ótica do cumprimento de uma lei com validade, vigência e de baixíssima eficácia poderia comprometer os reais efeitos da mitigação de emissões de gases de efeito estufa (SABBAG, 2009).

Sob essa ótica qual seria a melhor posição? O que deve de fato prevalecer?

Sob tais questionamentos é necessário entender a natureza jurídica do direito ambiental. Sem sombra de dúvida, ele faz parte dos chamados direitos difusos, em que não há identificação de titularidade, ou seja, o direito ao meio ambiente transcende o coletivo, ele está acima até mesmo dele, é o planetário não pertencendo a um grupo específico, nem tampouco numerado.

Dessa forma o entendimento de que a adicionalidade pode ser considerada quando a exigência legal é em sua grande maioria deve prevalecer, haja vista que se a lei ambiental pátria de uma determinada localidade não é eficaz no combate aos danos ambientais causados, ou não 
inibe de forma efetiva a sua ocorrência, não haveria o porque de negar-se ou até mesmo afastar a aplicação de um projeto de MDL que tem como principal meta mitigar os impactos ambientais decorrentes das emissões de gases de efeito estufa, sendo um mecanismo voluntário e um incentivo financeiro para aquela região que por longos anos vinha descumprindo os preceitos legais e que "acorda", mesmo que tardiamente, ou até mesmo, impulsionada por uma razão financeira, a mudança de atitude para com o meio que a circunda.

No tocante a questão ambiental, os meios coercitivos de aplicação de normas não são os únicos mecanismos de eficácia legal da legislação, ao contrário, normas de caráter voluntário, que tenham como base a educação ambiental, ensejam, um melhor resultado na questão da mitigação dos impactos ambientais.

Logo, a voluntariedade dos aspectos legais costuma produzir um resultado mais efetivo quando a matéria a ser legislada é o meio ambiente. De forma alguma devendo a não imposição de normas severas no tocante a seara ambiental, entretanto, saliente-se que a voluntariedade da mitigação deve ser encarada como uma mudança de atitude do próprio cidadão que percebe, não pela imposição, mas pela realização de uma necessidade, a validade de seu dever cívico para com sua nação e sua mudança de postura com relação ao meio ambiente.

Ainda, existe corrente na literatura que defende a possibilidade de se exigir a implementação de um projeto de MDL, por meio de um termo de ajustamento de conduta TAC, como forma de compensação ambiental (SABBAG, 2009).

Tal corrente defende que a voluntariedade é do país anfitrião com relação a questão dos projetos de MDL e não a atividade de projeto propriamente dita. Correto o entendimento, uma vez que o fato da voluntariedade não é do idealizador do projeto, mas sim da parte membro. Nessa interpretação poderíamos entender que havendo um dano ambiental irreparável causado pelo proponente do projeto de MDL e este vindo a obter recursos advindos da venda dos créditos de carbono, nada mais justo que esses créditos sejam destinados a um fundo ambiental público que teria como principal meta a reparação do dano ambiental (SABBAG, 2009) 
A.2 Os critérios de sustentabilidade

A Comissão Interministerial de Mudanças Global do Clima e A Autoridade Nacional Designada Brasileira, exerceram a competência para estabelecer os critérios de sustentabilidade para projetos de MDL hospedados no Brasil.

O Anexo III, da Resolução 1/03 dá destaque as contribuições da atividade de projeto para cada um dos cinco aspectos: (MCT, 2008)

- $\quad$ sustentabilidade ambiental local;

- desenvolvimento das condições de trabalho e a geração líquida de empregos;

- distribuição de renda;

- capacitação e desenvolvimento tecnológico; $e$

- integração regional e a articulação com outros setores.

É importante dar ênfase às contribuições que podem ser, de fato, atribuídas à implementação da atividade de projeto, separando de forma clara dos outros possíveis benefícios advindos de outras atividades das empresas proponentes do projeto. Vale a pena observar que as reduções de emissões de gases de efeito estufa não se configuram como contribuição à sustentabilidade ambiental local, mas global (MCT, 2008).

As informações devem ser coerentes com as demais apresentadas nos outros documentos (DCP ou Relatório de Validação) devendo ser apresentadas objetivamente e de forma mais clara possível.

Ressalte-se que não há da obrigatoriedade do projeto de MDL contemplar todos os cinco parâmetros acima indicados, pois isso variará conforme o escopo de cada atividade de projeto proposta no âmbito do MDL.

Caso a Comissão Interministerial entenda que a atividade de projeto proposta no âmbito do MDL contribua para o Brasil atingir o seu desenvolvimento sustentável, emitirá uma Carta 
de Aprovação, caso contrário esta atividade poderá ser posta em revisão ou poderá ser aprovada com ressalvas (MCT, 2008).

A.3 Ciclos do Projeto de MDL

- $1^{\circ}$ Fase: Documento de concepção do projeto (PDD), em inglês e DCP, em português.

O Documento de Concepção do Projeto - PDD, em inglês- deve ser Estruturado e entregue atendendo os requisitos determinadas pelo Conselho Executivo do Mecanismo de Desenvolvimento Limpo.

O PDD deve ser entregue no formulário correspondente e em mesma versão que foi enviada à Entidade Operacional Designada para validação, que será encaminhada ao Conselho Executivo do MDL quando do requerimento para registro.

Existem formulários diferenciados de acordo com o tipo de projeto a ser desenvolvido: projeto de redução de emissões (grande escala e pequena escala) e projeto de florestamento e reflorestamento (grande escala e pequena escala).

Na versão em português pede-se especial atenção para que a tradução seja fiel à versão em inglês e que seja utilizada a nomenclatura oficial para as instituições e para os termos criados no âmbito do Protocolo de Quioto.

O documento de concepção do projeto deverá valer-se de uma metodologia para estimativa da linha de base e monitoramento antecipadamente aceitos pelo Conselho Executivo do MDL. A metodologia é de vital importância, uma vez que a quantidade de créditos de carbono a ser emitida a cada conclusão do ciclo do projeto dependerá proporcional e diretamente da linha de base calculada e da forma que se conduz o processo de monitoramento. 
Caso inexista metodologia aplicável à atividade de projeto a ser proposta no âmbito do MDL, os participantes de projeto deverão submeter uma nova metodologia para análise do Painel de Metodologia ou do Grupo de Trabalho de Florestamento ou Reflorestamento

Esse grupo de trabalho poderá recomendar a sua aprovação pelo Conselho Executivo do MDL. Em caso positivo, a metodologia cai em domínio público e pode ser utilizada por terceiros.

Após a metodologia tem se a escolha da duração do projeto indicando-se a data de início e término com a consequente do período de obtenção de créditos entre o máximo de sete anos, com possibilidade de duas renovações por igual prazo, ou o máximo de dez anos, sem possibilidade de renovação, salvo períodos específicos em projetos florestais.

Deverá ainda, o projeto apresentar cálculo estimativo da quantidade/volume de gases de efeito estufa emitidos pela fonte e cálculo estimativo das futuras emissões permitindo demonstrar as adicionalidades do projeto, bem como um Plano de Monitoramento das reduções de emissão de gases efeito estufa ou de ou absorção de gás carbônico em decorrência da atividade de projeto, ou seja, é a narrativa como as reduções de emissão serão mensuradas e contabilizadas pelos participantes do projeto. Essa medida tem como meta principal garantir a fiscalização e a certificação dessa atividade.

Tratará o DCP da análise dos impactos ambientais do projeto fazendo a indicação dos impactos ambientais considerados significativos pelos participantes do projeto.

Importante ser destacado que MDL não contêm uma lista de atividades de projeto. Dessa forma qualquer atividade de projeto que reduza ou absorva GEE, desde que observadas as exigências legais, podem ser elegíveis no âmbito do MDL. 
- $2^{\circ}$ Fase: Cartas-Convite

Devem ser enviadas as cópias das cartas-convite a comentários que foram enviadas aos atores envolvidos aos interessados e/ou afetados pelas atividades de projeto (MCT, 2008).

Se as atividades de projeto estiverem em apenas um ou vários municípios, no limite geográfico de apenas um só ente federativo (Estado / Distrito Federal), as cartas-convite devem ser enviadas, pelo menos, aos seguintes atores (stakeholders) (MCT, 2008):

a) Prefeitura de cada município envolvido;

b) Câmara dos vereadores de cada município envolvido;

c) Órgão ambiental estadual;

d) Órgão (ãos) ambiental (is) municipal (is);

e) Fórum Brasileiro de ONG's e Movimentos Sociais para o Meio Ambiente e Desenvolvimento - FBOMS;

f) Associações comunitárias cujas finalidades guardem relação direta ou indireta com a atividade de projeto;

g) Ministério Público estadual do estado envolvido ou, conforme o caso, o Ministério Público do Distrito Federal e Territórios;

h) Ministério Público Federal.

Se as atividades de projeto envolverem mais de um ente federativo, e forem submetidas à Comissão Interministerial em um único Documento de Concepção de Projeto, por meio de agrupamento (bundling), as cartas-convite devem ser enviadas, pelo menos, aos mesmos atores (stakeholders) acima descritos, para cada atividade de projeto incluída no agrupamento, considerando o limite geográfico de cada município e ente federativo envolvido (MCT, 2008). 
Estendendo-se o projeto pelos limites geográficos de mais de um estado da federação ou Comissão Interministerial de Mudança Global do Clima do Distrito Federal, mas que não envolva o agrupamento (bundling), e que seja submetida à CIMGC em um único DCP, por meio de agrupamento, as cartas-convite devem ser enviadas, pelo menos, aos seguintes destinatários: (MCT, 2008)

a) Governo de cada estado ou Distrito Federal envolvido;

b) Assembléia legislativa de cada estado envolvido ou, no caso do Distrito Federal, Câmara Legislativa;

c) Órgão ambiental federal;

d) Órgãos ambientais estaduais envolvidos;

e) Fórum Brasileiro de ONG's e Movimentos Sociais para o Meio Ambiente e Desenvolvimento - FBOMS

f) Entidades nacionais cujas finalidades guardem relação direta ou indireta com a atividade de projeto;

g) Ministério Público estadual dos estados envolvidos elou, conforme o caso, o Ministério Público do Distrito Federal e Territórios;

h) Ministério Público Federal.

Em todos as situações relatadas, as cartas-convite devem ser claramente endereçadas a cada um dos atores acima listados, devendo ser enviadas por correio, com aviso de recebimento, ou pessoalmente, pelo menos 15 (quinze) dias antes do início do processo de validação, de forma que eventuais comentários recebidos sejam incorporados no Relatório de Validação a ser submetido à Secretaria Executiva da Comissão Interministerial (MCT, 2008).

O prazo começa a ser contado no dia em que o Documento de Concepção de Projeto for disponibilizado para consulta aos stakeholders internacionais no sítio internet do MDL no Secretariado da Convenção do Clima (MCT, 2008).

As cartas-convites devem conter: (MCT, 2008) 
I - conter nome e tipo da atividade de projeto, conforme consta no documento de concepção de projeto $-D C P$

II - informar endereço eletrônico específico da página da internet onde poderão ser obtidas cópias, em português, da última versão disponível do DCP em questão, bem como da descrição da contribuição da atividade de projeto ao desenvolvimento sustentável, conforme Anexo III da Resolução $n^{\circ} 1$, garantindo que esta página permaneça acessível até, no mínimo, o término do processo de registro da atividade de projeto no Conselho Executivo do MDL; e

III - fornecer endereço para que os atores que não possuam acesso à internet possam solicitar, por escrito e em tempo hábil, ao proponente de projeto, cópia impressa da documentação mencionada no item anterior (MCT, 2008)

- $3^{\circ}$ Fase: Validação

Esta exigência da Autoridade Nacional Designada Brasileira se mostra distinta da maioria dos demais países em desenvolvimento, os quais não costumam exigir o relatório de validação previamente à emissão da Carta de Aprovação (SABAGG, 2009).

Tal procedimento permite que sejam submetidos à Comissão Interministerial projetos mais elaborados do ponto de vista técnico, visando evitar a analisar de toda e qualquer idéia de projeto que, na visão do proponente, seria elegível para o MDL. Desta forma, pretende-se aprovar projetos de MDL hospedados no Brasil já validados e que, portanto, possuam consistência técnica para futuro registro perante o Conselho Executivo do MDL, evitando a emissão de Cartas de Aprovação a projetos que venham a ser rejeitados pelo Conselho Executivo (SABAGG, 2009).

Conforme relata o Artigo 3, inciso III, da Resolução ${ }^{\circ}{ }^{1}$ : 
"O Relatório de Validação da atividade de projeto preparado pela Entidade Operacional Designada, na forma a ser submetida ao Conselho Executivo do MDL para registro, em inglês, também deve ser submetido à Comissão Interministerial"

Portanto é a validação é uma espécie de auditoria que analisa o cumprimento de todas as exigências aplicáveis ao MDL devendo a Entidade Operacional Designada realizar a emissão de um Relatório de Validação concluindo pela aprovação ou não do projeto, ao qual se dará publicidade.

O relatório deve fazer referência, de forma clara e inequívoca, à versão do PDD que está sendo analisada, bem como à versão da metodologia utilizada, que deve estar aprovada e publicada pelo Conselho Executivo do MDL (MCT,2008).

No Relatório de Validação, não deve constar nenhuma ressalva ou ação corretiva pendente. O fato de a Carta de Aprovação só ser emitida pelo Governo Brasileiro após a Validação não deve constar como uma pendência no Relatório de Validação, devendo esta questão ser esclarecida no Relatório de Validação com a seguinte frase: "Previamente à submissão do Documento de Concepção do Projeto e do Relatório de Validação ao Conselho Executivo do MDL, o Projeto deverá obter a aprovação por escrito da participação voluntária da AND do Brasil, inclusive a confirmação de que o Projeto contribui para que o país atinja o desenvolvimento sustentável"1 (MCT, 2008).

Dois requisitos merecem destaque em relação a Entidade Operacional Designada:

a) Que seja estabelecida em território nacional e tenha capacidade de assegurar o cumprimento dos requerimentos pertinentes da legislação pertinente;

b) Não possua conflito de interesse com ao menos um dos participantes do projeto realize validação ou verificação /certificação das reduções de emissão.

\footnotetext{
${ }^{1}$ Tradução livre do inglês: "Prior to the submission of the Project Design Document and the Validation Report to the CDM Executive Board, the Project will have to receive the written approval of voluntary participation from the DNA of Brazil, including the confirmation that the Project assists the country in achieving sustainable development".
} 
Caso a EOD não esteja convencida do projeto, deverá requerer os esclarecimentos e adequações necessários previamente à emissão do relatório final de validação (MCT, 2008).

- $4^{\circ}$ Fase: Carta de aprovação

Conforme ressaltado anteriormente, o órgão responsável pela emissão da Carta de Autorização é o Ministério da Ciência e Tecnologia que é auxiliado pela Coordenação Geral de Mudanças Globais de Clima - CGMGC e pela Comissão Interministerial de Mudança Global do Clima - CIMGC.

Deverão os proponentes a elegibilidade de projetos de MDL enviar à Secretaria Executiva da Comissão Interministerial, em versão impressa e eletrônica (com conteúdo idêntico), os seguintes documentos: (MCT, 2008)

- Documento de Concepção de Projeto (em inglês e em português);

- Anexo III;

- Cartas-convite a comentários;

- Relatório de Validação (em inglês e em português);

- Declaração sobre responsável pela comunicação e dados para contato;

- Declaração sobre conformidade com a legislação ambiental;

- Declaração sobre conformidade com a legislação trabalhista;

- Declaração sobre a situação da Entidade Operacional Designada-EOD.

O prazo para aprovação do projeto pela Comissão será de 60 dias para, contados da "data da primeira reunião ordinária da Comissão subsequente ao recebimento dos documentos mencionados no art. $3^{\circ}$ pela Secretaria Executiva da Comissão" (MCT, 2008). 
A Figura 7 a seguir mostra as etapas do procedimento para obtenção da carta de aprovação pela Comissão Interministerial.

Figura 33: Prazo para submissão, divulgação e aprovação de projeto de MDL

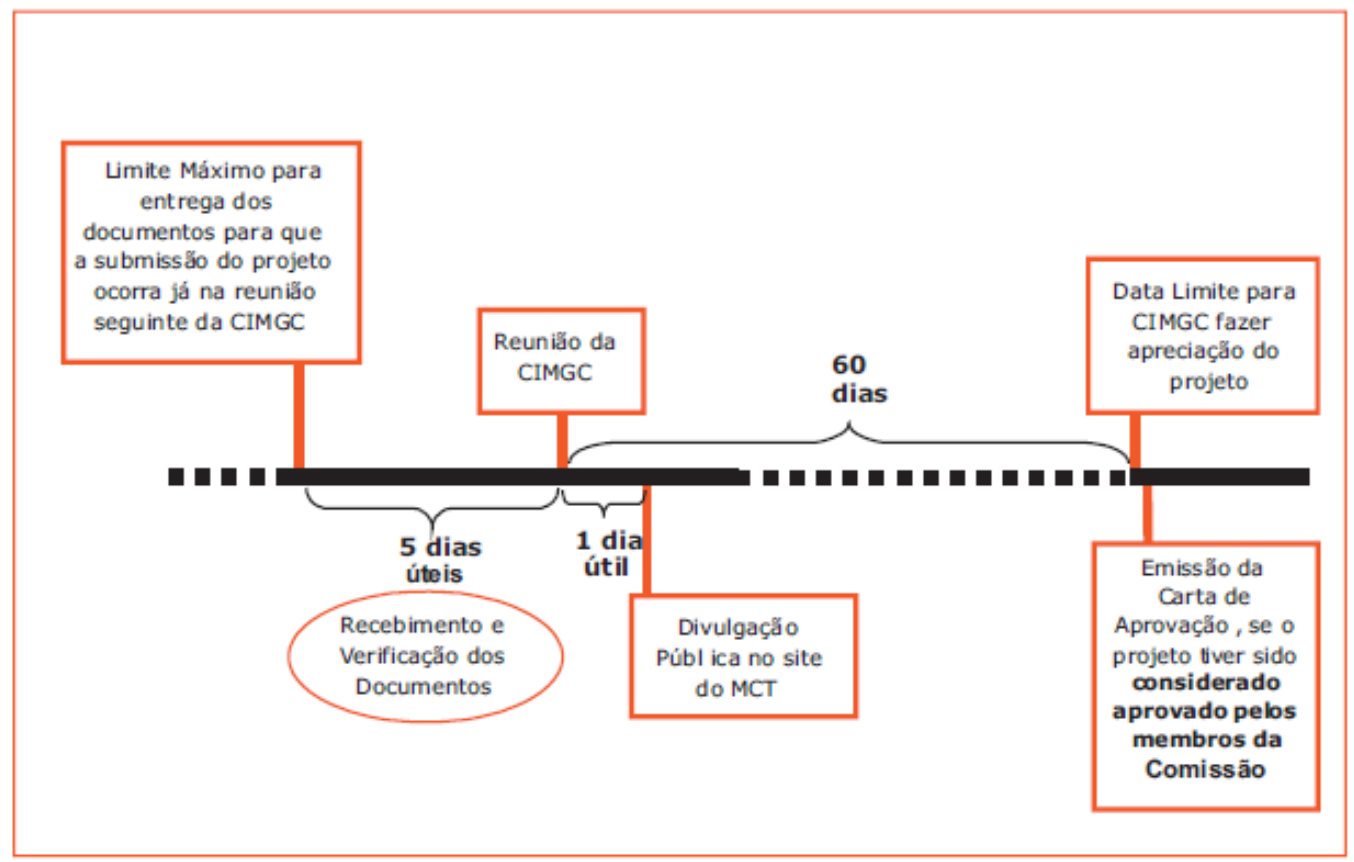

Fonte: Manual para Submissão de Atividades de Projeto no Âmbito do MDL Comissão Interministerial de Mudança Global do Clima Coordenação-Geral de Mudanças Globais de Clima Ministério da Ciência e Tecnologia, Brasil, 2008.

$\mathrm{O}$ artigo $7^{\circ}$, por sua vez trás a seguinte redação:

"Se uma atividade de projeto for considerada aprovada com ressalvas, a Secretaria Executiva da Comissão Interministerial encaminhará ofício ao responsável pela comunicação, indicando as ressalvas que devem ser sanadas para a emissão da Carta de Aprovação. Os proponentes nacionais da atividade de projeto deverão atender as ressalvas feitas pela Comissão Interministerial em até 60 (sessenta) dias após a data de recebimento desse ofício, sob pena de as atividades de projeto serem consideradas não submetidas” 
$\mathrm{Na}$ hipótese da complementação dos documentos ou ainda sejam necessários esclarecimentos a Secretaria Executiva da Comissão, será enviado ofício aos participantes do projeto para protocolo da documentação e/ou informações complementares, caso em que o prazo de 60 dias começará a contar na data da próxima reunião da Comissão após o protocolo dessa documentação, se a mesma for considerada completo pela Secretaria Executiva da Comissão (MCT, 2008).

Uma atividade de projeto será considerada aprovada com ressalva caso sua contribuição ao desenvolvimento sustentável seja considerada adequada pelos membros da Comissão Interministerial, mas sejam constatados erros de edição ou quaisquer incongruências consideradas de menor relevância (MCT, 2008).

A Carta de Aprovação terá sua emissão encaminhada imediatamente após as correções terem sido consideradas satisfatórias pela Secretaria Executiva da Comissão

Interministerial. Caso necessário, outro ofício poderá ser enviado aos proponentes do projeto requerendo esclarecimentos adicionais (MCT, 2008).

A figura 8 trás o procedimento para obtenção de Carta de Aprovação aprovada com ressalvas. Se uma atividade de projeto for considerada em revisão, a Secretaria Executiva da Comissão Interministerial encaminhará ofício ao responsável pela comunicação indicando as exigências a serem cumpridas, conforme determinado pela Comissão Interministerial. Os proponentes nacionais da atividade de projeto deverão atender as exigências feitas pela Comissão Interministerial em até 60 (sessenta) dias após a data de recebimento deste ofício, sob pena de as atividades de projeto serem consideradas não submetidas (MCT, 2008).

Conforme redação do artigo $8^{\circ}$ da Resolução nº 3 :

"Uma atividade de projeto será considerada em revisão caso sua contribuição ao desenvolvimento sustentável necessite de esclarecimentos adicionais, a critério dos membros da Comissão Interministerial, ou caso sejam constatados erros de edição ou quaisquer incongruências consideradas relevantes", 
Segundo a redação do Artigo $3^{\circ}$ da Resolução $n^{\circ} 5$ :

“A Carta de Aprovação terá sua emissão encaminhada imediatamente após as correções terem sido consideradas satisfatórias pelos membros da Comissão Interministerial em sua reunião subseqüente à resposta ao ofício. Para que essa análise ocorra logo na reunião seguinte, é preciso que haja uma antecedência mínima da resposta de 10 (dez) dias úteis”.

Figura 34: Prazo para projetos aprovado com ressalvas.

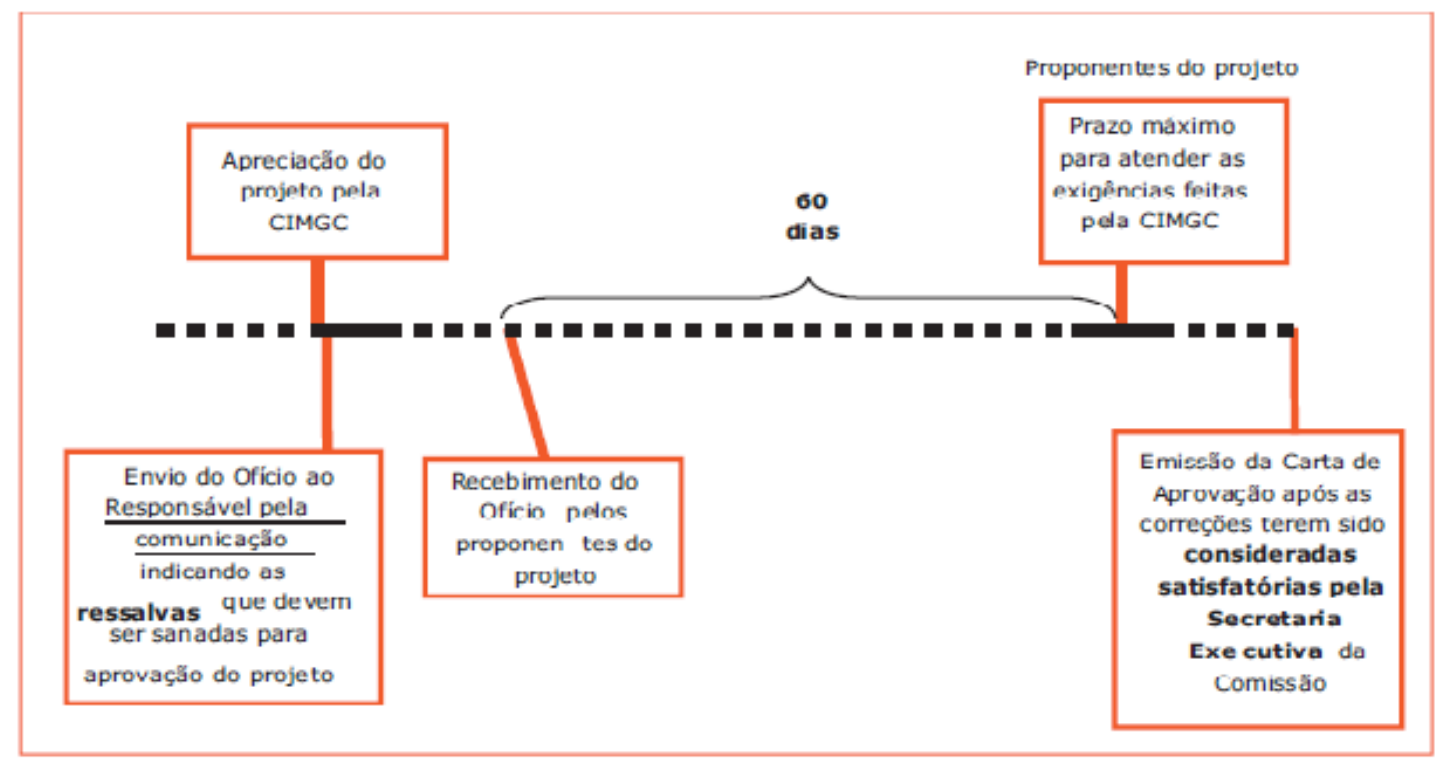

Fonte: Manual para Submissão de Atividades de Projeto no Âmbito do MDL Comissão Interministerial de Mudança Global do Clima Coordenação-Geral de Mudanças Globais de Clima Ministério da Ciência e Tecnologia, Brasil, 2008.

O próximo passo é a publicação dessa Carta de Aprovação no website oficial da Comissão contemplando os possíveis investidores uma segurança na obtenção de créditos de carbono e que o projeto atende às normas nacionais aplicáveis ao MDL (SABAGG, 2009).

Essa confirmação, em certa medida, estende-se aos critérios internacionais, já que e exigido Relatório de Validação para emissão da Carta de Aprovação pelo Governo Brasileiro. 
No entanto, convém ressaltar que há caso de projetos de MDL, embora poucos, que foram devidamente validados por uma EOD e aprovados pelo Brasil, mas tiveram o seu registro rejeitado pelo Conselho Executivo do MDL, na ONU (SABAGG, 2009).

Figura 35: Procedimento para obtenção de Carta de Aprovação em projetos com revisão:

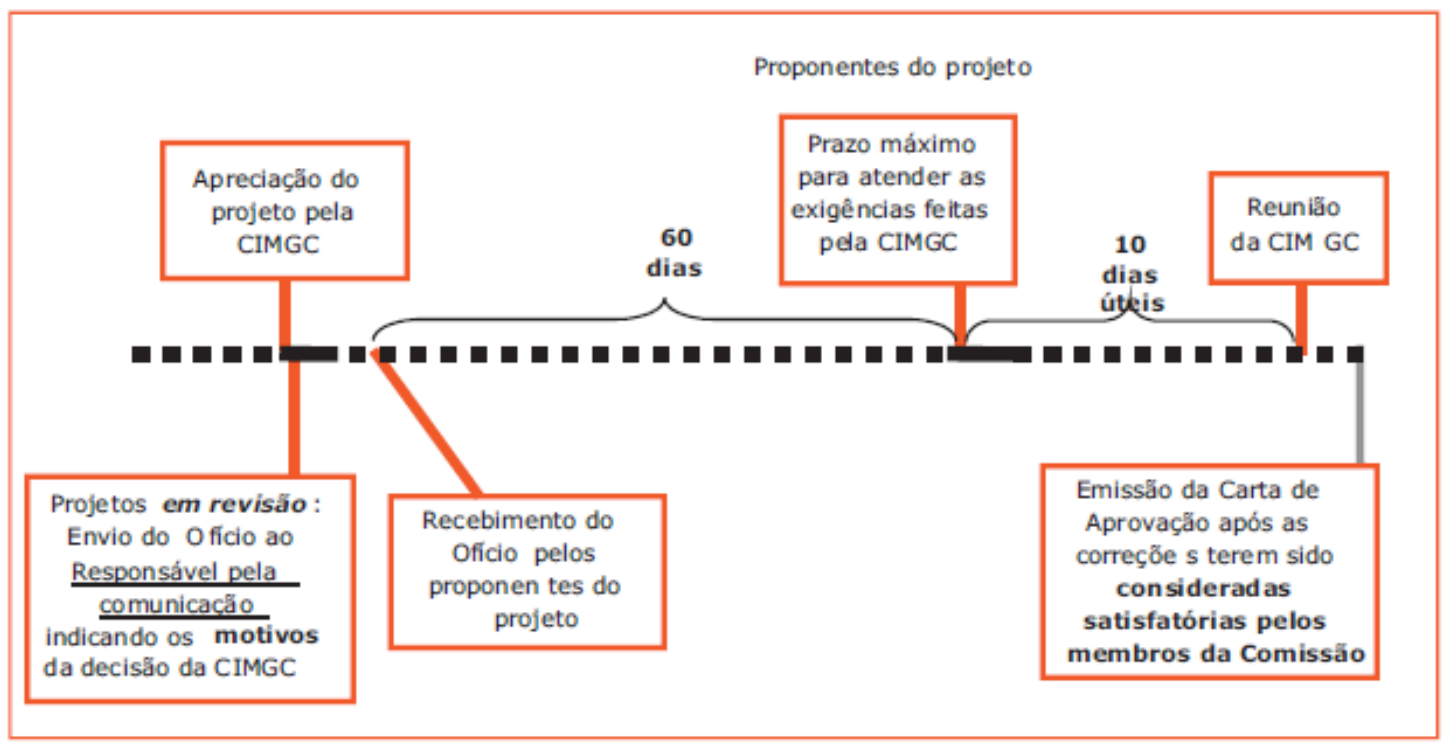

Fonte: Manual para Submissão de Atividades de Projeto no Âmbito do MDL Comissão Interministerial de Mudança Global do Clima Coordenação-Geral de Mudanças Globais de Clima Ministério da Ciência e Tecnologia, Brasil, 2008.

Essa confirmação, em certa medida, estende-se aos critérios internacionais, já que e exigido Relatório de Validação para emissão da Carta de Aprovação pelo Governo Brasileiro. No entanto, convém ressaltar que há caso de projetos de MDL, embora poucos, que foram devidamente validados por uma EOD e aprovados pelo Brasil, mas tiveram o seu registro rejeitado pelo Conselho Executivo do MDL, na ONU (SABAGG, 2009). 
- $5^{\circ}$ Fase: Registro do projeto

O registro é pré-requisito para a verificação, certificação e emissão das RCEs relativas a essa atividade de projeto.

É nesse momento que oficializa o projeto na ONU como MDL e da declaração de sua consistência no âmbito internacional com o "Sistema de Quioto".

A Entidade Operacional Designada contratada publicará o Documento de Concepção do Projeto público e aguardará, por 30 dias, comentários das Partes envolvidas e dos demais stakeholders, tornando públicos os eventuais comentários recebidos.

Após ter tomado a decisão de validar o projeto, a Entidade Operacional Designada deverá informar tal decisão aos participantes do projeto e, caso seja positiva, submeter o projeto para registro ao Conselho Executivo por meio de formulário eletrônico disponível no website oficial do Conselho, juntamente com uma explicação do procedimento que adotou para levar em consideração eventuais comentários recebidos durante a consulta pública do projeto, pelo prazo de 30 dias, e uma cópia do Relatório de Validação (SABAGG, 2009).

Derradeiramente, o registro do projeto no Conselho Executivo acontecerá no prazo de 8 semanas contado da data da entrega do formulário de registro, desde que toda a documentação exigida e demais regulamentações pertinentes tenha sido submetida e não seja requerida a sua revisão por uma Parte envolvidas ou pelo menos três membros do Conselho Executivo.

- $6^{\circ}$ fase: Monitoramento das atividades de redução

O monitoramento deve obedecer a metodologia utilizada e as características técnicas constantes do Documento de Concepção do Projeto - DCP. 
O monitoramento abordará a captura de arquivo de dados necessários à estimativa ou medição das reduções de emissão e da linha de base durante o período de obtenção de créditos, bem como as eventuais emissões que ocorrerem em razão das atividades do projeto (emissões fugitivas). Essas informações deverão ser devidamente documentadas de forma controlada e organizada, visando a garantir a qualidade dos dados e possibilitar a futura emissão de créditos de carbono (SABAGG, 2009).

Caso haja inconformidades no sistema de coleta, armazenamento e interpretação de dados poderão afetar a futura emissão de créditos de carbono, completa ou parcialmente, o que gerará prejuízos para os participantes de projetos e terceiros (ex.: compradores), nos termos contratuais estabelecidos entre as partes envolvidas.

- $7^{\circ}$ Fase: Verificação e certificação das reduções

Cada Relatório de Monitoramento deverá ser submetido à verificação e certificação de uma Entidade Operacional Designada.

Conforme previsão expressa do art. 27(e) do Anexo da Decisão 17/CP.7 é importante ser frisado que Entidades Operacionais Designadas que houverem realizado a validação do projeto não poderá realizar a verificação da certificação das reduções do mesmo projeto, salvo quando o Conselho Executivo autorizar como é o caso de atividades de pequena escala.

A certificação é a garantia emitida pela Entidade Operacional Designada de que, durante um período de tempo especificado, uma atividade de projeto atingiu as reduções das emissões antrópicas de gases de efeito estufa por fontes conforme verificado.

Assim, o procedimento de verificação visa a atestar a integridade das reduções de emissão, podendo, para tanto, a Entidade Operacional Designada conduzir inspeções no local, 
analisar os documentos referentes ao projeto, realizar entrevistas, testar o funcionamento dos equipamentos de monitoramento, analisar a aplicação da metodologia e tornar outras medidas para se certificar da correta implementação do Plano de Monitoramento validado e registrado. É muito importante que a Entidade Operacional Designada esteja certa da integridade das reduções de emissão a serem verifica das e certificadas, pois essas entidades são as responsáveis pela emissão de eventuais créditos de carbono irregulares (SABAGG, 2009).

Dessa forma importante é o Relatório de Certificação, pois trará requisitos e sustentação para a emissão das Reduções Certificadas de Emissão pelo Administrador do Registro do MDL, conforme instruções do Conselho Executivo.

- $\quad 8^{a}$ fase: Emissão e alocação de RCEs

O Relatório de Certificação deverá conter um requerimento ao Conselho Executivo para emissão de RCEs, devendo o Conselho instruir o Administrador do Registro do MDL a emitir as Reduções Certificadas de Emissão para a conta pendente do Conselho no Registro do MDL, consoante estabelecido nos arts. 64 . a 66 do Anexo da Decisão 17/ CP. 7.

Essa emissão deverá ocorrer no prazo de 15 dias contados da submissão do requerimento ao Conselho Executivo, a não ser que ao menos uma Parte envolvida ou três membros do Conselho Executivo requeiram a revisão do requerimento de emissão de RCEs submetido pela Entidade Operacional Designada que certificou as reduções de emissão. 


\section{REFERÊNCIAS BIBLIOGRÁFICAS}

AB’SABER, A. - Terra de Direitos in Brasil de Fato, n 472 São Paulo, 2012.

Acordos de Marraqueche da Conferência das Partes da Convenção Quadro das Nações Unidas sobre Mudança do Clima, Novembro de 2001.

A Guide to the Climate Change Convention Process. Disponível em <www.unfccc.int>

AMARAL, W.A.N. Mudanças climáticas, mercado de carbono e potencialidades do Brasil para desenvolvimento de projetos para Mecanismo de Desenvolvimento Limpo. Preços Agrícolas, v.14, n.155, p.7 - 9, 1999.

ANDRADE, J.C.S. \& COSTA, P. Mudança climática, protocolo de kyoto e mercado de créditos de carbono: desafios à governança ambiental global, o\&s - v.15 - n.45 - Abril/Junho $-2008$

ANDREUX, F.G \& CERRI, C.C. Current trends in the research on soil changes due to deforastation, burning and cultivation in the Brazilian tropics. Toxicol.Environ.Chem. 20$21,1989$.

Anexo II - Modalidades e procedimentos simplificados para atividades de projetos de mecanismo de desenvolvimento limpo de pequena escala. Disponível em 〈http://www.mct.gov.br/Clima/negoc/pdf/cp8_an2.pdf>

ANJOS, N.; MOREIRA, D.D.O.; DELLA LUCIA, T.M.C. Manejo integrado de formigas cortadeiras em reflorestamentos. In: DELLA LUCIA, T.M.C. (Ed.). As formigas cortadeiras. Ed. Folha de Viçosa, p.212-241, 1993.

ASSOCIAÇÃO BRASILEIRA DE CELULOSE E PAPEL (BRACELPA) - Relatório estatístico 2010-2001. Disponível em: www.bracelpa.org.br. Acesso julho de 2011. 
ASSOCIAÇÃO BRASILEIRA DE EMPRESAS DE LIMPEZA PÚBLICA E RESÍDUOS ESPECIAIS (ABRELPE) - Panorama dos Resíduos Sólidos no Brasil, Abrelpe, São Paulo, 2010.

ASSOCIAÇÃO BRASILEIRA DE NORMAS TÉCNICAS. (ABNT) Resíduos Sólidos: classificação, NBR 10.004. Rio de Janeiro, 1987.

ASSOCIAÇÃO BRASILEIRA DE PRODUTORES DE FLORESTAS PLANTADAS (ABRAF) - Anuário estatístico da ABRAF, 2001. Disponível em www.abraf.com.br acesso julho de 2011.

ASSOCIAÇÃO MINEIRA DE SILVICULTURA (AMS). O eucalipto no Brasil. In: Boletim AMS. Março de 2001.

ASSOCIAÇÃO DOS GEÓGRAFOS BRASILEIROS (AGB) et al. Para os investidores do PCF (Prototype Carbon Fund). Carta-manifesto contrária ao Projeto Plantar, enviada em 26 de março de 2003. Disponível em <http://www.fern.org/pubs/ngostats/Plantport.htm>. Acesso em 22 fev. 2007

ASSOCIATION OF CONSCIENCE ON OCUPATIONAL PREVENTION/BRAZIL (ACPO) et al. Ao Sr. Ken Newcombe - Senior Manager Carbon Finance Business - Banco Mundial. Cartasmanifesto contrárias ao Projeto Plantar, enviadas em 17 de setembro e em 4 de dezembro de 2003.

AUKLAND, Louise; COSTA, Pedro Moura et al. Criando as Bases para o Desenvolvimento Limpo: preparação do Setor de Gestão de Uso da Terra. Londres: Sue Mylde, IIED, 2002, p. 19. Disponível em 〈http://www.cdmcapacity.org/CDM_Booklet_Por.pdf >

BARBIERI, José Carlos. Desenvolvimento e meio ambiente - As estratégias de mudanças da Agenda 21. 5. ed. Petrópolis: Editora Vozes, 1997. 
BARREIRA, L. P., PHILIPPI JR, A. Panorama da situação do tratamento e disposição de resíduos urbanos na cidade de São Paulo: aterro Bandeirantes e sítio São João. In: $21^{\circ}$ Congresso Brasileiro de Engenharia Sanitária e Ambiental, 2001, João Pessoa. $21^{\circ}$ Congresso Brasileiro de Engenharia Sanitária e Ambiental. Rio de Janeiro: ABES, 2001.

BASTOS, Anna C Saramago e FREITAS, Antônio Carlos; Agentes e Processos de Interferência, Degradação e Dano Ambiental; In: CUNHA, Sandra Baptista e GUERRA, Antônio J. Teixeira (Org.); Avaliação e Perícia Ambiental Rio de Janeiro; Ed. Bertrand Brasil, Rio de Janeiro, 1999.

BELLEN, Hans Michael Van. Indicadores de Sustentabilidade. Rio de Janeiro: Editora FGV, 2005.

BELMIRO, Tânia R. "A Evolução do Mercado Global de Carbono". In Carbono Ciência e Mercado Global. SANQUETTA, Carlos Roberto; ZILIOTTO, Marco Aurélio B, editores. Curitiba: UFPR - Universidade Federal do Paraná e Instituto Ecoplan, 2004.

BENCKE,G.A. Monocultura pode decretar o fim do pampa: in entrevista Cadernos IHU em formação ano IV, n $^{\circ} 27,2008$

BENNATI, Paula. "Evolução das Negociações acerca das Mudanças Climática Globais". In Questões de Direito Ambiental. JUNIOR, Arlindo Philippi; ALVES, Alaôr Caffé, editores. São Paulo: Signus Editora, 2004.

BHANDARI, P. Historical perspective on negotiations. In: Climate change: Post- Kyoto Perspectives from the South. New Delhi: Tata Energy Research Institute, 1998.

BINKOWSKI, P.\& FILLIPI, E.E. Os discursos sobre o desenvolvimento frente às políticas públicas de incentivo à implantação de cultivos de eucalipto na metade sul do rio grande do sul in Revista Raízes, vol. 27, n 1, jan/jun, 2008.

BM\&F. Perguntas Freqüentes sobre o Mercado de Carbono. Bolsa de Mercadorias \& Futuros: São Paulo, $2^{\mathrm{a}}$ edição. 
BNDES. Efeito Estufa e a Convenção sobre Mudança do Clima. Coordenação de Pesquisa em Mudanças Globais do Banco Nacional de Desenvolvimento Econômico e Social - Área de Planejamento, Ministério da Ciência e Tecnologia. Rio de Janeiro: BNDES, 1999.

BNDES/UNCTAD; O Mecanismo de Desenvolvimento Limpo - Guia de orientação. Rio de Janeiro: FGV Editora, Dezembro 2002.

BOFF, L. Ecologia: Grito da Terra, Grito dos Pobres. Rio de Janeiro: Sextante, 2004, p. 120.

BORN, R.H e TALOCCHI, S. Compensações por serviços ambientais: sustentabilidade ambiental com inclusão social. In Proteção do Capital Social e Ecológico por meio de compensações por serviços ambientais prestados. São Paulo, Peirópolis, São Lourenço da SerraSP, Vitae Civilis, 2002.

BRAGA, B.; HESPANHOL, I.; CONEJO, J. G. L.; MIERZWA, J. C.; BARROS, M. T. L. de; SPENCER, M.; PORTO, M.; NUCCI, N.; JULIANO, N.; EIGER, S. Introdução à engenharia ambiental. São Paulo: Pearson Prentice Hall. 2005. 306 p.

BRANCO, S.M., Ecossistêmica- Uma Abordagem Integrada dos Problemas do Meio Ambiente, Editora Edgard Blucher Ltda, 1989.”

BRANCO. Samuel Murgel. O Meio Ambiente em Debate. 32a impressão. São Paulo: Editora Moderna, 2001, p. 59.

BRASIL, E. G. (19 Mai 2005) Ibama inspeciona guseiras em Marabá. 2005, IBAMA. Disponível em <http://www.ibama.gov.br/>.

BRASIL. COMISSÃO INTERMINISTERIAL DE MUDANÇAS GLOBAIS DO CLIMA CIMGC. Estabelece os procedimentos para aprovação das atividades de projeto no âmbito do Mecanismo de Desenvolvimento Limpo do Protocolo de Quioto e dá outras providências. Resolução n.1 de 11 de setembro de 2003.

COMISSÃO INTERMINISTERIAL DE MUDANÇAS GLOBAIS DO CLIMA -

CIMGC. Status atual das atividades de projeto no âmbito do Mecanismo de 
Desenvolvimento Limpo (MDL) no Brasil e no mundo: Última compilação do site da CQNUMC 30 de setembro 2008. Disponível em: www.mct.gov.br Acesso em: agosto de 2009.

. Resolução no. 1, de 11 de setembro de 2003. Aprovada pela Portaria no. 863, de 27 de novembro de 2003. Diário Oficial da União. Brasília, DF, 2 dez. 2003. Disponível em: http://www.mct.gov.br/upd_blob/2736.pdf>. Acesso em: agosto de 2009.

Resolução no. 2, de 10 de agosto de 2005. Diário Oficial da União. Seção 1. Brasília, DF, 27 set. 2005. Disponível em: 〈http://www.mct.gov.br/upd_blob/2735.pdf〉. Acesso em: agosto de 2009.

Protocolo de Kyoto à Convenção sobre Mudança do Clima, 1997. Editado e traduzido pelo Ministério da Ciência e Tecnologia - MCT com o apoio do Ministério das Relações Exteriores. Disponível em: http://www.mct.gov.br/clima/quioto/protocolo.htm. Acesso em: agosto de 2009.

BRASIL, LEI N ${ }^{\circ}$ 9795, Dispõe sobre a educação ambiental, institui a Política Nacional de Educação Ambiental e dá outras providências, de 27 de Abril de 1999.

, Lei de Saneamento Básico nº 11.145, de 05/01/2007.

O mecanismo de desenvolvimento limpo nos empreendimentos de manejo de resíduos sólidos urbanos e o impacto do Projeto de Lei $\mathbf{n}^{\circ}$ 5296/2005. Brasília: Ministério das Cidades, 2006. (Saneamento para todos, n.3). Disponível em: http://snis.gov.br, acesso em: setembro de 2009.

CALSING, Renata de Assis. O Protocolo de Quioto e o Direito ao Desenvolvimento Sustentável. Porto Alegre: Sergio Antonio Fabris Editor,2005.

CAMARGO, B. Produção ilegal de carvão vegetal gera desmatamento e escravidão na Amazônia. 2006. Disponível em <http://www.reporterbrasil.com.br/exibe.php?id=622>

Acesso em: 30 Abr 2008. 
CAMPOS, C. P. de. A Conservação das Florestas no Brasil, Mudança do Clima e o Mecanismo de Desenvolvimento Limpo. Rio de Janeiro, 2001. 169 f. Dissertação (Mestrado em Ciências em Planejamento Energético) - COPPE, Universidade Federal do Rio de Janeiro.

CAPRA, Fritjof. A teia da vida: uma nova compreensão científica dos sistemas vivos. São Paulo: Cultrtrix, 1997.

CAVALCANTI. Desenvolvimento e respeito à natureza: uma introdução termodinâmica à economia da sustentabilidade. In: FERREIRA, Leila da Costa e VIOLA, Eduardo (Org.). Incertezas da sustentabilidade na globalização, p.319. Campinas, Editora da Unicamp, 1996.

CETESB, Seminário Internacional Gestão de Resíduos Sólidos em Regiões Metropolitanas, 28 e 29 de setembro de 2005.

CHOMENKO, Luiza. Pampa: um bioma em risco de extinção. Revista IHU on line, n²47, ano VII, 2007.

COLLER, Taciana. "Bird inicia negociação de carbono". Publicada no Jornal Valor Econômico de 5 de setembro de 2002. Disponível <http://www.ana.gov.br/AcoesAdministrativas/RelatorioGestao/Rio10/Riomaisdez/index.php. 694.html.>. Acesso em 20 dez. 2006

COMISSÃO MUNDIAL SOBRE MEIO AMBIENTE E DESENVOLVIMENTO. Nosso Futuro Comum. 2. ed. Rio de Janeiro: Editora da Fundação Getúlio Vargas, 1991.

CONEJERO, M. A. Marketing de Créditos de Carbono: Um Estudo Exploratório. Dissertação de Mestrado, apresentada à Faculdade de Economia, Administração e Contabilidade de Ribeirão Preto/USP - Área de concentração: Marketing. Ribeirão Preto, 2006.

CONTI, J. B. Considerações sobre as Mudanças Climáticas Globais. Revista do Departamento de Geografia, v. 16, 2005. 
Convenção Quadro das Nações Unidas sobre Mudança do Clima. Ministério de Ciência e Tecnologia, Brasília, 2001.

COSTA, Paulo de Oliveira. Resposta Político-Econômica às Mudanças Climáticas: origem, situação atual e incertezas do mercado de créditos de carbono. 2004. 128 f. Dissertação (Mestrado Profissional da Escola de Administração) - Universidade Federal da Bahia, 2004.

CRUZ, S.R.S O Mercado de Carbono em Aterros Sanitários na cidade de São Paulo Contribuição dos projetos do MDL para a gestão local de resíduos sólidos, Trabalho de conclusão de curso, gestão ambiental, USP, 2009.

CRUZ, S.R.S \& PAULINO, S.R. Projetos de Mecanismo de Desenvolvimento Limpo (MDL) em aterros sanitários e a gestão de resíduos sólidos na cidade de São Paulo V Encontro Nacional da Anppas 4 a 7 de outubro de 2010 Florianópolis - SC - Brasil.

CUNHA, Kamyla Borges. Mecanismo de Desenvolvimento Limpo: evolução do instrumento e suas perspectivas. 2005. 198 f. Dissertação (Mestrado em Planejamento de Sistemas Energéticos) - Universidade Estadual de Campinas, Faculdade de Engenharia Mecânica, Comissão de Pós-Graduação em Engenharia Mecânica Planejamento de Sistemas Energéticos, 2005.

DALCOMUNI, S. M. A implantação da Aracruz Celulose no ES - principais interesses em jogo. Dissertação de Mestrado em Economia, UFRRJ, 1990.

DAVID, L. Monocultivo de árvores, papel e celulose na Metade Sul do RS. 2006

Decisão 19 CP.9 - Modalidades e Procedimentos para as Atividades de Projetos de Florestamento e Reflorestamento no âmbito do Mecanismo de Desenvolvimento Limpo no Primeiro Período de Compromisso do Protocolo de Quioto. Disponível em:<http://www.mct.gov.br/clima/negoc/pdf/cp9_19p.pdf> Acesso em 8 fev. 2006.

DERANI, Cristiane. Direito ambiental econômico. São Paulo: Max Limonad, 1997. 
DIAS, E. C.; ASSUNÇÃO, A. A.; GUERRA, C. B.; CURY, G. C.; BARROS, J. B.; GUERRA, R. B.; PRAIS, H. A. Processo de trabalho e saúde dos trabalhadores na produção artesanal de carvão vegetal em Minas Gerais, Brasil. Cad. Saúde Pública, Rio de Janeiro, jan-fev, 2002.

DUARTE, A. C. Projetos De MDL Em Aterros Sanitários No Brasil: Alternativa Para O Desenvolvimento Sustentável. Dissertação de Mestrado, Engenharia de Recursos Hídricos e Ambiental, Setor de Tecnologia, Universidade Federal do Paraná - UFPR, 2006.

DUBEUX, Carolina Burle Schmidt; SIMÕES, André Felipe; JUNIOR, José Deocleciano de Siqueira Silva (colaboração); SCHAEFF, Roberto, POPPE, Marcelo Khaled (orientação, coordenação e supervisão geral). "Parte III A Mercado internacional de créditos de carbono". In Mudança do Clima Brasília: Cadernos Nae, vol. II (Núcleo de Assuntos Estratégicos da Presidência da República), 2005.

EPA - Environment Protection Agency. Climate Change and Waste. Reducing Waste Can Make a Difference. 2010

F.A.O. Efectos ecológicos de los eucaliptos. Colección Estudio Fao Montes $\mathrm{N}^{\circ}$ 59. Roma 89 p p.1987

FELDMANN, Fabio. “Apresentação”. In I Seminário do Fórum Brasileiro de Mudanças Climáticas Protocolo de Kyoto: O Brasil em Apoio ao Planeta. FELDMANN, Fabio; MACEDO, Laura Valente; FURRIELA, Rachel Biderman, orgs. São Paulo: Fórum Brasileiro de Mudanças Climáticas, 2001.

FERRUCCIO, R. S., Avaliação do gerenciamento de resíduo sólido em doze municípios paulistas, com aterro classificado como adequado pela CETESB. Campinas, SP, 2003.

FILHO, Luiz Gylvan Meira. "Mudanças Climáticas e Prevenção de Desastres". In "Rio + 10 Brasil Uma década de transformações”. FELDMANN, Fabio, Editor e CRESPO, Samyra e 
DRUMMOND, José Augusto, co-editores. Rio de Janeiro: ISER - Instituto de Estudos da Religião, Ministério do Meio Ambiente, Fórum Brasileiro de Mudanças Climáticas, 2002.

FIORILLO, Celso Antonio Pacheco. Curso de Direito Ambiental Brasileiro. 6 ed. São Paulo: Saraiva, 2005.

FISCHER, G. et al. Global Agro-Ecological Assessment for Agriculture in the $21^{\text {st }}$ Century, Laxenburg: FAO, 2001.

FOREST STEWARDSHIP COUNCIL (FSC BRASIL). Disponível <http://www.fsc.org.br〉. Acesso em 21 jan. 2008.

FRANGETTO, Flávia W.; GAZANI, Flávio R. Viabilização Jurídica do Mecanismo de Desenvolvimento Limpo (MDL) no Brasil. O Protocolo de Kyoto (sic) e a Cooperação Internacional. São Paulo: Editora Fundação Peirópolis, 2002.

FRANGETTO, F. W. O mecanismo de desenvolvimento limpo pelo olhar do direito ambiental. In: KLINK, C. (org.). Quanto mais quente, melhor?: Desafiando a sociedade civil a entender as mudanças climáticas. São Paulo: Peirópolis; Brasília, DF: IEB - Instituto Internacional de Educação do Brasil, 2007.

FRIEDLINGSTEIN, P., L. BOPP, P. CIAIS, J. DUFRESNE, L. FAIRHEAD, H. LETREUT, P. MONFRAY, AND J. ORR, Positive feedback between future climate change and the carbon cycle, Geophys. Res. Lett., 28(8), 1543-1546, 2001.

FUNDAÇÃO GETÚLIO VARGAS - FGV, O Mecanismo de Desenvolvimento Limpo: guia de orientação. Coordenação-geral Ignez Vidigal Lopes - Rio de Janeiro: Fundação Getúlio Vargas, 2002.

GOLDEMBERG, José. "Energia e Desenvolvimento". Artigo - Instituto de Estudos Avançados da Universidade de São Paulo. São Paulo.1988 
GOLDEMBERG, J. Energia, meio ambiente e desenvolvimento. São Paulo: Editora da Universidade de São Paulo - Edusp, 1998, 234p.

GOLDEMBERG, José. “O Caminho até Joanesburgo". In TRIGUEIRO, André (coord.). Meio Ambiente no Século 21. Rio de Janeiro: Sextante, 2003.

GORE, Albert. A Terra em balanço: ecologia e espírito humano. São Paulo: Augustus, 1993.

GRUPO BANCO MUNDIAL. Financiamentos de Carbono. Publicado na página de Programas Especiais. bancomundial.org.br/index.php/content/view_folder/2426.html.> GRUPO PLANTAR. Projeto Carbono. Disponível em <http://www.plantar.com.br/>. Acesso em 05 abril. 2011

HESS, S. Carvão vegetal de matas nativas: é necessário e urgente proibir. Jornal da Ciência, 28/06/07.

HIEB, M.; HIEB, H. Water vapor rules the greenhouse system. 2006. Disponível em: <http://mysite.verizon.net/mhieb/WVFossils/greenhouse_data.html>.

IABR - INSTITUTO AÇO BRASIL - Estatística da produção siderúrgica brasileira, Disponível em: www.acobrasil.org.br. Acesso em julho de 2011.

IBAM - INSTITUTO BRASILEIRO DE ADMINISTRAÇÃO MUNICIPAL - IBAM, Gestão integrada de resíduos, Coordenação de Karin Segala, Rio de Janeiro, 2007.

IBGE - Instituto Brasileiro de Geografia e Estatística. Censo Brasileiro, 2010

IBGE - Instituto Brasileiro de Geografia e Estatística. Pesquisa Nacional de Saneamento Básico, 2000.

IBRACON (1995, p. 5), Disponível em: (www.ucb.br/apresenta/trabalho.ppt).

ICLEI-BRASIL. Mudanças Climáticas e Desenvolvimento Limpo: Oportunidades para Governos Locais: um guia do ICLEI.Coordenação geral Laura Silvia Valente de Macedo. Rio de Janeiro: ICEI/LACS, 2005. 
IETA - INTERNATIONAL EMISSION TRADING ASSOCIATION Brazil opens carbon credit market. Disponível em ieta.org/ieta/www/pages/index.php?IdSitePage=954 >.

IGRE - Porque respeitar o zoneamento, opinião técnica de pesquisadores da UFRGS e de associados da IGRE, Porto Alegre, 2007.

IPCC. Climate Change 2001: the scientific basis. HOUGHTON, J.T. et al. Cambridge University Press, 881p.2001.

IPCC. Climate Change 2001: Mitigation. Contribution of Working Group III to the Third Assessment Report of the Intergovernmental Panel on Climate Change. Cambridge, United Kington , and New York, United States, Cambridge University Press.

IPCC. Guidelines for National Greenhouse Inventories: Reference Manual (Vol.3). 1996. Disponível em: <http://www.ipcc-ngip.iges.or.jp/public/gl/invs6>. Acesso em 12/12/2005.

IPCC. Intergovernmental Panel on Climate Change. Summary for Policymakers. 2001. < www.ipcc.ch/pub.htm > Acesso em: set. 2009.

IPCC. Intergovernmental Panel on Climate Change Guidelines for National Greenhouse Gas Inventories. v 3, 1994. < www.ipcc.ch/pub.htm >

IPCC, Summary for Policymakers: A Report of Working Group I of the Intergovernmental Panel on Climate Change, 2001

IPEA - Instituto de Pesquisa Econômica Aplicada. O MECANISMO DE DESENVOLVIMENTO LIMPO E O FINANCIAMENTO DO DESENVOLVIMENTO SUSTENTÁVEL NO BRASIL. Brasília: IPEA, 2000.

ITAÚ UNIBANCO HOLDING AS. Relatório Anual do Unibanco 2006. Disponível em <http://ww13.itau.com.br/portalri/index.aspx?Url=http://ww13.itau.com.br/PortalRI/HTML/port /infofinan/rao.shtml>. Data de acesso: 14/12/09. 
IUCN (INTERNATIONAL UNION FOR CONSERVATION OF NATURE AND NATURAL RESORCES); UNEP (UNITED NATIONA ENVIRONMENT PROGRAMME); WWF (WORLD WILDLIFE FOUND). World Conservation Strategy: Living Resource Conservation for Sustainable Development. Gland, Switzerland \& Nairobi, Kenya: IUCN, Unep, WWF, 1980.

JACOB, P.R \& BESEN, G.R Gestão de resíduos sólidos em São Paulo: desafios da sustentabilidade in Estud. av. vol.25 no.71 São Paulo Jan./Apr. 2011

JACOBI, P. R. Cidade e meio ambiente: percepções e práticas em São Paulo. São Paulo, Ed. Annablume, 2000.

JACOBY, H. D.; SCHMALENSEE, R.; WING, I. S.. Toward a useful arquitecture for climate change negotiations, [s.l.]: MIT, Joint Program on Science and Policy of Global Change, 1999.

JAYAL, N.D. Destruction of water resources - The most critical ecological crisis of east Asia. Ambio, XIV (2):95-98, 1985.

JR. Arlindo Philippi e ALVES, Alaôr Caffé. "Uma Introdução ao Direito Ambiental: Conceitos e Princípios". In "Curso Interdisciplinar de Direito Ambiental”. JR. Arlindo Philippi e ALVES, Alaôr Caffé, editores. São Paulo: Editora Manole Ltda,2005.

KEELING, C.D. \& WHORF T.P - Trends: A compendium of data on global change, 2005.

KOOPMANS, J. Além do Eucalipto - o papel do Extremo Sul. Teixeira de Freitas: DDH Centro de Defesa dos Direitos Humanos. $2^{\mathrm{a}}$ edição, 2006.

KORMONDY, E. J. Concepts of ecology. Englewoods Cliffs: Prentice-Hall, Inc.1996.

LASCHEFSKI, K. e ASSIS, W. A produção de Eucalipto e Pinus no Brasil. GT Energia do FBOMS, agosto de 2006, mimeo. 
LIMA, W.P. Impacto ambiental do eucalipto. 2.ed. São Paulo, Universidade de São Paulo, 1996.

LIMA, W.P.; ZAKIA, M.J.B.; LIBARDI, P.L. \& SOUZA FILHO, A. P. 1990. Comparative evapotranspiration od Eucalypus, Pine and Cerrado vegetation measured by the soil water balance method. IPEF International, Piracicaba, 1:5-11.

LLOSA, Silvia e MONZONI, Mário. Critérios e Indicadores de Sustentabilidade de Projetos MDL. Publicação do Observatório do Clima - Rede Brasileira de ONGs e Movimentos Sociais em Mudanças Climáticas, apresentado na COP 9, Milão, 2003.

LOVELOCK, James. A vingança de gaia. Tradução de Ivo Korytowski. Rio deJaneiro: Intrínseca, 2006.

MACHADO, Paulo Affonso Leme. Direito Ambiental Brasileiro. 9. ed. São Paulo: Malheiros Editores, 2001.

MACHADO, Paulo Affonso Leme. "Princípio da Precaução no Direito Brasileiro e no Direito Internacional e Comparado". In Princípio da Precaução. VARELLA, Marcelo Dias e PLATIAU, Ana Flávia Barros, orgs. Belo Horizonte: Livraria Del Rey Editora Ltda., 2004.

MADDOX, John. O que falta descobrir. Tradução: Ronaldo de Biasi. Rio de Janeiro: Editora Campus, 1999.

MAIA, R.M. Paradoxos da legislação ambiental: uma análise de conflitos socioambientais em torno das monoculturas de eucalipto na Comunidade Cana Brava - Norte de Minas Gerais, 2008

MARTINS, Osvaldo. Determinação do potencial de seqüestro de carbono na recuperação de matas ciliares na região de São Carlos-SP, tese doutorado, São Carlos, 2005, UFSCAR.

MARCONDES, Sandra. Brasil, amor à primeira vista! Viagem ambiental no Brasil do século XVI ao XXI. São Paulo: Editora Peirópolis, 2005. 
MATTES, D e TAGNIN, R As plantações de eucaliptos e os seus efeitos ambientais:

recursos hídricos, ALAI, Brasil, 2009.

MCT. Comunicação Nacional Inicial do Brasil à Convenção-Quadro das Nações Unidas sobre Mudança do Clima. Brasília: Coordenadoria-Geral de Mudança Global do Clima e MCT, nov 2004.

MCT, Manual para Submissão de Atividades de Projeto no Âmbito do MDL Comissão Interministerial de Mudança Global do Clima Coordenação-Geral de Mudanças Globais de Clima Ministério da Ciência e Tecnologia, Brasil, 2008.

MELGAREJO, L. Agricultura x monocultura: o empobrecimento do bioma in Revista do Instituto Humanitas Unisinos, 247, ano VII, 2007.

MELLIS, Carlos. Forum Continuado de Energia - Aterro Bandeirantes. Apresentação. Agosto de 2004, Disponível <www.ebape.fgv.br>. Data de acesso : 09/09/2009.

MIGUEZ. José Domingos Gonzáles. O Mecanismo de Desenvolvimento Limpo: a proposta e as perspectivas brasileiras. Trabalho apresentado no evento Sustentabilidade na Geração e Uso de Energia no Brasil: os próximos vinte anos,UNICAMP, 18 a 20 de fevereiro de 2002.

MILANEZ, B \& PORTO, M.F.S A ferro e fogo: impactos da siderurgia para o ambiente e a sociedade após a reestruturação dos anos 1990 IV Encontro Nacional da Anppas 4,5 e 6 de junho de 2008, Brasília - DF - Brasil.

MILARÉ, Edis. Direito do Ambiente. 3. ed. São Paulo: Editora Revista dos Tribunais, 2004.

Ministério da Ciência e Tecnologia. Resolução $n^{0} 1$ da Comissão Interministerial de Mudanças Globais do Clima de 11 de setembro de 2003. Brasília: 2003. Disponível em <http://www.mct.gov.br/clima/cigmc/pdf/Resolucao01p.pdf 
MONZONI, M. Critérios de Sustentabilidade para Projetos MDL no Brasil: Adaptado de Paper escrito por Silvia Llosa para o Instituto de Pesquisa Ambiental da Amazônia (IPAM) e para o Observatório do Clima. Buenos Aires, 2004.

MONTEIRO, M. A. Siderurgia na Amazônia: aspectos energéticos e sociais. Capítulo do livro Energia na Amazônia, 1994.

MONTEIRO, R. C. Novas ruralidades e políticas públicas. In: FROEHLICH, J. M.;DIESEL, V. Desenvolvimento rural: Tendências e debates contemporâneos. Ijuí: Ed. Unijuí, 2006.

MOTTA, S. R. \& FERRAZ, C. O mecanismo de desenvolvimento limpo e o financiamento do desenvolvimento sustentável no Brasil. Texto para discussão $\mathrm{n}^{\circ} 761$ do Instituto de Pesquisa Econômica Aplicada - IPEA. Ministério do Planejamento, Orçamento e Gestão, 2000.

MUYLAERT, Maria Silvia. Análise dos Acordos Internacionais sobre Mudanças Climáticas sob o ponto de vista do uso do conceito de Ética. 2000. 250 f. Tese (Doutorado em Ciências em Planejamento Energético) - Programa de Pós-Graduação em Engenharia, Universidade Federal do Rio de Janeiro, COPPE, 2000.

MUYLAERT, M. S; SALA, J; FREITAS, M. A. V. de. Consumo de Energia e Aquecimento do Planeta - Análise do Mecanismo de Desenvolvimento Limpo - MDL - do Protocolo de Quioto - Estudos de Caso. Rio de Janeiro: COPPE, 2000.

NETO, W. G. Estado e agricultura no Brasil: Política agrícola e modernização econômica brasileira 1960-1980. São Paulo: HUCITEC,1995.

ODUM, E.P. Fundamentals of ecology. 3 ed. Philadelphia: W. B. Saunders, 1971. 474p.

OLIVEIRA,F.R, MENEGASSE,L.N \& DUARTE,U. Impacto ambiental do eucalipto na recarga de água subterrânea em área de cerrado, no médio vale do Jequitinhonha, Minas Gerais in XII Congresso Brasileiro de Águas Subterrâneas, Florianópolis, 2002. 
OLHOFF, Anne, MARKANDYA, Anil, HALSNAES, Kirsten, TAYLOR, Tim. CDM sustainable development impacts. Roskilde: UNEP RISO CENTRE: 2004.

ORGANIZAÇÃO INTERNACIONAL DO TRABALHO (OIT) - Possibilidades Jurídicas de Combate à Escravidão Contemporânea. Brasília: Organização Internacional do Trabalho, 2007.

ORGANIZAÇÃO MUNDIAL DA SAÚDE (OMS). The World Health Report 2007 - A safer future: global public health security in the 21st. century.

PAULA, J. A. (Org.). Biodiversidade, população e economia: uma região de mata atlântica. 1ª. ed. Belo Horizonte: UFMG/Cedeplar; ECMVC; PADCT/CIAMB, 1997. 672 p.

PAULINO, V. T.; SANCHEZ, M. J. F.; WERNER, J. C; GONÇALVES, M. A. Z. Efeito alelopático do Eucalyptus no desenvolvimento de forrageiras. Revista de Agricultura, Piracicaba, 62:17-35, 1987.

PAVAN, M. O., PARENTE, V. Projetos de MDL em Aterros Sanitários no Brasil: Análise Política, Socioeconômica e Ambiental. In: XXX Congreso de la Asociacion de Ingenieria Sanitaria y Ambiental, 2006, Montevidéo. Proceedings of XXX Congreso de la Asociacion de Ingenieria Sanitaria y Ambiental, 2006.

PEARCE, Fred. O aquecimento global: causas e efeitos de um mundo mais quente. São Paulo: Série Mais Ciência; Publifolha, 2002.

PEREIRA, André Santos. Do Fundo ao Mecanismo: Gênese, Características e Perspectivas para o Mecanismo de Desenvolvimento Limpo; ao Encontro ou de Encontro à Equidade? 2002. 192 f. Dissertação (Mestrado em Ciências em Planejamento Energético) - Universidade Federal do Rio de Janeiro, 2002. 
PEREIRA, André Santos e ROVERE, Emilio Lèbre La. "Parte I C - Síntese dos diálogos pósquioto". In Mudança do Clima Brasília: Cadernos Nae, vol. I (Núcleo de Assuntos Estratégicos da Presidência da República), 2005.

PINTO, A Ademar Pinto acusa Veracel de gerar desemprego em Guaratinga in entrevista setembro 2011. Disponível <http:// portaldoextremosul.com.br〉

Secretaria Municipal do Verde e do Meio Ambiente (SVMA), Planilha: Investimentos através dos créditos de carbono, 2009.

Secretaria Municipal do Verde e do Meio Ambiente (SVMA), Planilha: Créditos de Carbono - Aterro Bandeirantes, 2007.

Secretaria Municipal do Verde e do Meio Ambiente (SVMA), Resolução no 01/CONFEMA/2002, Dispõe sobre o Regimento Interno doFundo Especial do Meio Ambiente e Desenvolvimento Sustentável - CONFEMA, de 19 de dezembro de 2002.

—. Secretaria Municipal do Verde e do Meio Ambiente (SVMA), Resolução no 02/CONFEMA/2002, Dispõe sobre o Regulamento do Fundo Especial do Meio Ambiente e Desenvolvimento Sustentável - FEMA. de 19 de dezembro de 2002.

PNUD. 2010. The Human Development Report 1991. Nova York, United Nations Development Programme.

PORTO GONÇALVES, C.P - A globalização da natureza e a natureza da globalização, Rio de Janeiro, Civilização Brasileira, 2006.

Protocolo de Quioto. Ministério de Ciência e Tecnologia, Brasília, 2001. REIS, Fernando e CUNHA, kamyla Borges. "Instrumentos Legais e Regulamentares". In Mudança do Clima Brasília: Cadernos Nae, vol. II (Núcleo de Assuntos Estratégicos da Presidência da República), 2005 . 
RIBEIRO, A. M. et al, Perus: O caminho mais curto para Quioto: A conquista da participação pela Sociedade Civil, artigo do livro: O Pagamento por serviços ambientais: O mercado de carbono promove a inclusão social?, Organizador: Markus Brose, Goiânia, Ed da UCG, 2009.

RIBEIRO, M. A. Mineração e meio ambiente: problemas e perspectivas. Fundação JP: Análise e Conjuntura. Belo Horizonte, 15 (7-8): 3-19, set./out., 1995.

RIBEIRO, M. de S. O tratamento contábil dos créditos de carbono. Tese de livre docência apresentada à Faculdade de Economia, Administração e Contabilidade, campus de Ribeirão Preto / USP Ribeirão Preto, 2005.

RICE, E.L. Allelopathy. Orlando, Florida: Academic Press 2a ed. 1984.

RIOS, Aurélio Virgílio Veiga; DERANI, Cristiane. "Princípios Gerais do Direito Internacional Ambiental". In o Direito e o Desenvolvimento Sustentável - curso de Direito Ambiental. RIOS, Aurélio Virgílio Veiga; IRIGARAY, Carlos Teodoro Hugueney, orgs. São Paulo: Editora Fundação Peirópolis. Instituto Internacional de Educação do Brasil, 2005.

RIZZI, C. A. A questão da participação da comunidade do Distrito de Perus-(São Paulo/Brasil), no projeto MDL Aterro Bandeirantes, in Confins [Online], 11|2011, posto online em 25 Março 2011, Consultado em 03 Julho 2012. URL :http://confins.revues.org/6870;

ROCHA, M. T. Aquecimento global e o mercado de carbono: uma aplicação do modelo Cert.Piracicaba,. Tese (Doutorado) - Escola Superior de Agricultura "Luiz de Queiroz" da Universidade de São Paulo. 2003.

RODRIGUES, Marcelo Abelha. Instituições de direito ambiental. São Paulo: Max Limonad, 2002.

ROHDE, G.M. MUDANÇAS DE PARADIGMA E DESENVOLVIMENTO SUSTENTADO in DESENVOLVIMENTO E NATUREZA: Estudos para uma sociedade sustentável. Clóvis Cavalcanti (Org.) INPSO/FUNDAJ, Instituto de Pesquisas Sociais, 
Fundação Joaquim Nabuco, Ministério de Educação, Governo Federal, Recife, Brasil. Outubro 1994. Disponível <http://168.96.200.17/ar/libros/brasil/pesqui/cavalcanti.rtf〉

ROTONDARO, G. P., Avaliação da contribuição dos projetos de Mecanismo de Desenvolvimento Limpo (MDL) em aterros sanitários para os aspectos de desenvolvimento sustentável no Brasil, Trabalho de conclusão de curso, Pós-graduação em Gestão e Tecnologias Ambientais, Escola Politécnica, Universidade de São Paulo, 2007.

SABBAG, O protocolo de Quioto e seus créditos de carbono: manual jurídico brasileiro de mecanismo de desenvolvimento limpo. $2^{\mathrm{a}}$ ed. São Paulo, LTr, 2009.

SACHS, IGNACY. Estratégias de transição para o século XXI. In:BURSZTYN (Org). Para pensar o desenvolvimento sustentável. São Paulo: Brasiliense, 1994.

SAlES, B.B \& DALMOLIn, K.P. CARVÃo VEGETAL: Aspectos Técnicos, Sociais, Ambientais e Econômicos: in Nota Técnica X, Cenbio, USP, 2008.

SALGADO, A,A.R e MAGALHÃES Júnior, A,P. Impactos da silvicultura de eucalipto no aumento das taxas de turbidez das águas fluviais: o caso de mananciais de abastecimento público de Caeté/MG, Belo Horizonte 47-57 janeiro-junho Geografias, 2006

SCHARF, Regina. Manual de Negócios Sustentáveis. São Paulo: Editora FGV, 2004.

SCHLESINGER, S. Lenha nova para velha fornalha: a febre dos agrocumbustíveis. Rio de Janeiro. FASE, 2008.

SCHJETMAN, A. Agroindústria y pequena agricultura: experiências y opciones de transformacion. In : CEPAL/FAO/GTZ. Agroindutria y pequena agricultura: vínculos, potencialidades y oportunidades comerciales. Chile: Naciones Unidas, 1998.

SCHMITT, C. J. Sociedade, natureza e desenvolvimento sustentável: uma abordagem preliminar. Porto Alegre: PPGS/UFRGS, 1995.

SCOTTO, G.; LIMONCIC, F. Conflitos ambientais no Brasil. Rio de Janeiro: IBASE, 1997. 
SECRETARIADO PERMANENTE DA CONVENÇÃO. Convenção-Quadro das Nações Unidas sobre Mudança do Clima. Publicado pelo Programa das Nações Unidas para o Meio Ambiente/Unidade de Informação sobre Mudança do Clima em nome do Secretariado Permanente da Convenção; traduzidos pelos Ministérios da Ciência e Tecnologia e Relações Exteriores da República Federativa do Brasil. Genebra, 1992. 30p.

SEWELL, G.H. Administração e Controle da Qualidade Ambiental. São Paulo: EPU, 1998.

SILVA, C,E,M e GONÇALVES, C.W publicado no caderno Agropecuário, pág. 2, do jornal Estado de Minas, em 12 de Janeiro de 2004.

SILVA, T.N. \& CAMPOS, L M, S. Avaliação da produção e qualidade do gás de aterro para energia no aterro sanitário dos bandeirantes - SP in Engenharia sanitária. ambiental. Vol.13 - No 1 - jan/mar 2008, 88-96

SOARES, Guido Fernando Silva Soares. Direito Internacional do Meio Ambiente. São Paulo: Editora Atlas S.A., 2001.

SOCIEDADE BRASILEIRA DE SILVICULTURA (SBS) - Disponível em: < www.sbs.org.br> acesso em 2009.

SOUZA, G. D. Aplicação do mecanismo de desenvolvimento limpo: o caso NOVAGERAR, Pós-graduação em Geografia Humana do Departamento de Geografia da Faculdade de Filosofia, Letras e Ciências Humanas da Universidade de São Paulo - USP, São Paulo, 2007.

SUPTITZ, A. et al Prezados Membros do Conselho Executivo do Mecanismo de Desenvolvimento Limpo. Carta-manifesto contrária ao Projeto Plantar, enviada em junho de 2004. 
STAHEL, W.R. - The utilization-focused service economy: Resource efficiency and product life-extension. Pp. 178-190 in The Greening of Industrial Ecosystems, B.R. Allenby and D.J. Richards, eds. Washington, D.C. National Academy Press, 1994.

SUERTEGARAY,D - Monocultura do eucalipto cresce sem proteção ambiental e social in Revista do Instituto Humanitas Unisinos, 2010.

TALPO, E. Veredas no meio do "redemunho": o Processo de modernização na bacia hidrográfica do rio de Janeiro, Minas. Trabalho de conclusão de curso, geografia, USP, 2011. TOLEDO, M.H.S Plantação extensiva de eucalipto X culturas tradicionais in Revista do Instituto Humanitas Unisinos, 378, ano XI, 2011.

TURA, L.R e MATTOS, L. Financiamento da Transição para a Agroecologia in A proposta do Proambiente. Encontro Nacional de Agroecologia, 2002. Disponível em $<$ http://orgprints.org >

TURNER R.K, PEARCE D.W, BATEMAN I.J Environmental economics: an elementary introduction. Harvester Wheatsheaf, Hemel Hempstead. 1994.

UNDP. 1991. The Human Development Report 1991. Nova York, United Nations Development Programme.

UNEP Environment Programme (UNEP). The Sustainability Of Development - Nations 2002.

UNEP RISO e, Capacity Development for the CDM, CDM projects in the pipeline. Analysis and Database, Setembro de 2009,

VALVERDE, S.R As plantações de eucalipto do Brasil 2007 - textos técnicos - Centro de Inteligência em Florestas capturado em www.ciflorestas .com.br.

VENTURA, A. C. Mecanismo de desenvolvimento limpo (mdl): uma análise da regulação de conflitos socioambientais do projeto PLANTAR, Universidade Federal da Bahia- UFB, Salvador, 2008. 
VENTURA, A.C. \& ANDRADE, J. C. S. A. Conflitos socioambientais no projeto de mdl da Plantar S.A. interesses muito além das fronteiras locais, v. 4, n. 1, jan.-mar./2008, p. 124-157.

VIOLA, Eduardo. “As Complexas Negociações Internacionais para Atenuar as Mudanças Climáticas". In TRIGUEIRO, André (coord.). Meio Ambiente no Século 21. Rio de Janeiro: Sextante, 2003.

WARNER, J. e VERHALLEN, A. 2004. Multi-stakeholder Platforms for Integrated Catchment Management: Towards a comparative typology, paper presented in the International MSP Conference, Wageningen, The Netherlands, 2004.

WARNER, J. Multi-stakeholder platforms: integrating society in water resource management Ambiente e Sociedade, v. 8, n. 2, 2005.

WITT, H "O Eucalipto e a Água: Verdade ou Falácia?", Seminário Internacional sobre Eucalipto e seus Impactos, promovido em 2001 pela Comissão de Agricultura e Meio Ambiente da Assembleia Legislativa do Estado do Espírito Santo.

WORLD RAINFOREST MOVEMENT (WRM). Brasil: plantações de eucalipto da Plantar, créditos de carbono e população local. Disponível em <http://www.wrm.org.uy>. Acesso em 20 dez. 2006. 
